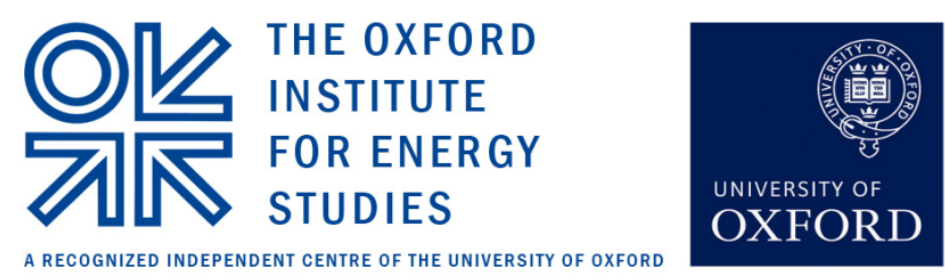

\title{
Central Asian and Caspian Gas Production and the Constraints on Export
}

\author{
Simon Pirani
}

NG 69

December 2012 
The contents of this paper are the author's sole responsibility. They do not necessarily represent the views of the Oxford Institute for Energy Studies, of any of the Institute's members, and/or of the author's other affiliations.

Copyright (C) 2012

Oxford Institute for Energy Studies

(Registered Charity, No. 286084)

This publication may be reproduced in part for educational or non-profit purposes without special permission from the copyright holder, provided acknowledgment of the source is made. No use of this publication may be made for resale or for any other commercial purpose whatsoever without prior permission in writing from the Oxford Institute for Energy Studies.

ISBN 978-1-907555-62-6 


\section{Acknowledgements}

Thanks are due to my colleagues Howard Rogers, Jonathan Stern, Yelena Kalyuzhnova, Laura El-Katiri and James Henderson, who kindly read all or parts of the text, and to Michael Chen, Andy Flower, Elham Hassanzadeh, Anouk Honoré, David Ledesma and Lavan Mahadeva in Oxford, and Tatiana Mitrova of the Skolkovo Energy Centre, who also helped in various ways. The opinions expressed, and the mistakes made, are mine alone.

I am very deeply indebted to a large number of people who work in, or with, the four countries covered, who shared insights and information, and helped me in other ways. Without their generosity - and hospitality, during trips made to the region between 2010 and 2012 - I could not have written the paper.

Thanks to David Sansom, who drew the maps, and to John Elkins for editing the text. 


\section{Preface}

Over the past decade, a substantial literature has emerged on the geopolitics of gas supplies in Central Asia and the Caspian region. These countries have been seen as "strategically located" in relation to a number of external gas markets and able to provide diversification away from current and potential dependence on Russian supplies. Some have even spoken of a new "Great Game" between Europe and Russia for these resources. Thousands of pages have been devoted to the development of many pipelines which have been proposed to take Central Asian, Caspian and Russian gas to various destinations via different routes, and the likely competition between these projects.

Much less attention has been paid to the details of gas production and utilisation in the countries themselves and how the timing of resource development is affected by domestic and external political and economic developments. This is understandable given the lack of easily available information and statistical complexity, particularly in relation to the Central Asian gas industries. But it is a crucial element of understanding why aside from their traditional markets in Russia and Iran, so little progress has been made in moving gas resources beyond regional borders, with the exception of pipelines to China, despite substantial political support in Europe.

Simon Pirani's study surveys the landscape of current and future gas development in these countries, explaining why the existence of substantial reserves does not necessarily guarantee rapid development, and certainly not when coupled with complex and costly pipeline export projects. Given the changes which are happening in all of the gas markets which surround the region, but particularly in Europe, the picture which emerges suggests that a substantial rethink of the conclusions from the literature of the 2000s is required in relation to the availability and timing of particularly Central Asian gas in the period up to 2030. If there is a Great Game emerging for Central Asian gas - and there is considerable doubt whether this is an appropriate concept - then it is clear that China is becoming the most important player.

Jonathan Stern

Chairman Natural Gas Research Programme and Senior Research Fellow, OIES 


\section{Contents}

1. Introduction: gas in the Central Asian/Caspian energy balance ..............................................1

2. Economic, political and social contexts ......................................................................10

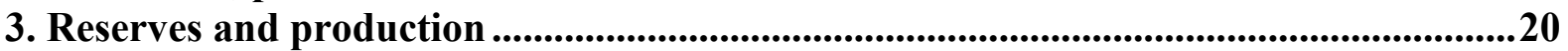

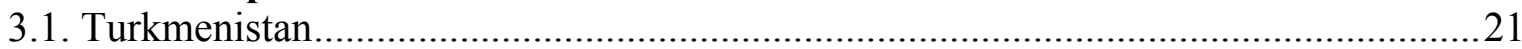

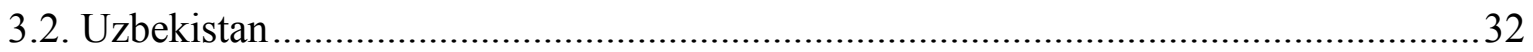

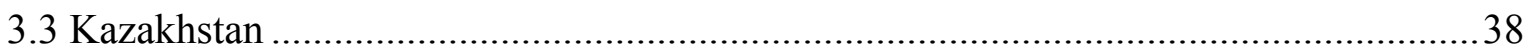

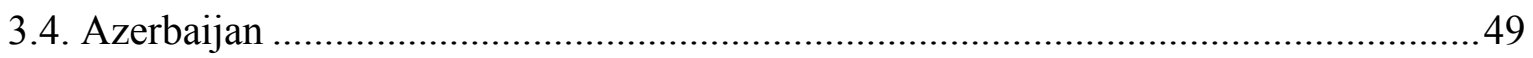

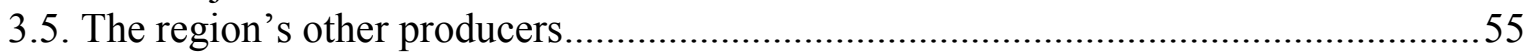

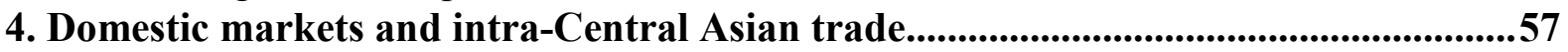

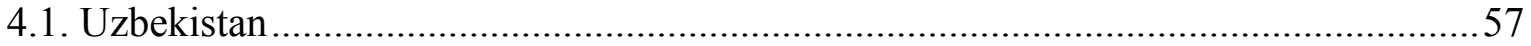

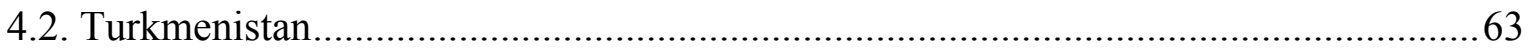

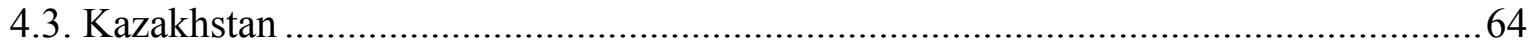

4.4. Uzbek exports to other Central Asian countries, and the alternatives ......................... 71

4.5 Gas consumption in Azerbaijan, Georgia and Armenia ............................................... 75

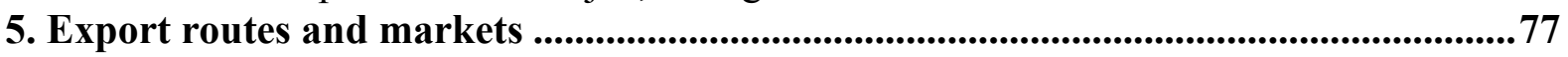

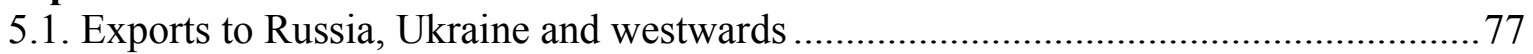

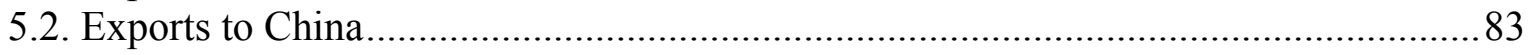

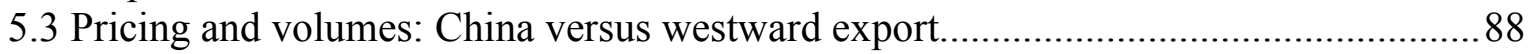

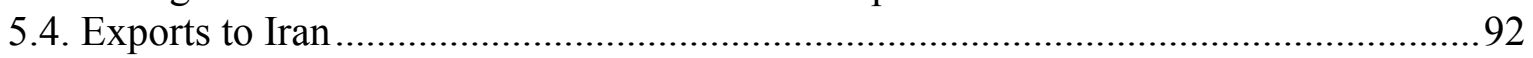

5.5. Exports from Azerbaijan to Georgia, Russia, Turkey and beyond .............................. 94

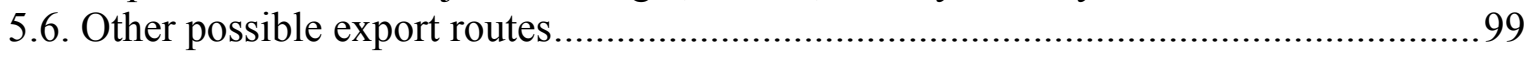

6. Future outlook and conclusions ..............................................................................................104

Appendix 1. Statistical and price information ..........................................................110

Appendix 2. Changes in trade flows.......................................................................111

Appendix 3. Turkmenistan: export revenues and their contribution to the economy ..113

Appendix 4. Production from projects in Uzbekistan with Gazprom participation .....119

Appendix 5. Gas supply problems in Uzbekistan ................................................................120

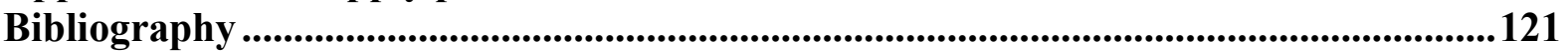

\section{Tables}

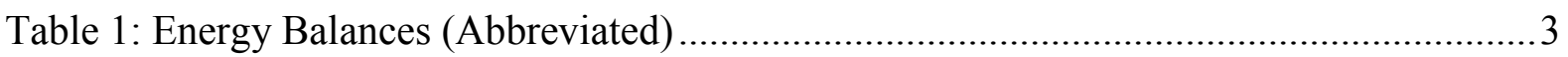

Table 2: Turkmenistan: Gas and Other Energy ................................................................ 5

Table 3: Energy Efficiency and Gas Efficiency Compared ................................................

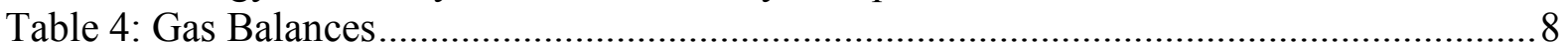

Table 5: Caspian and Central Asian Gas Exporters: economic indicators ............................ 11

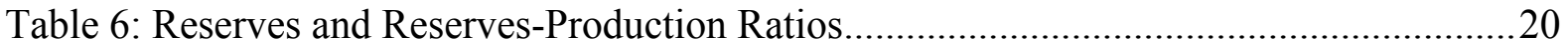

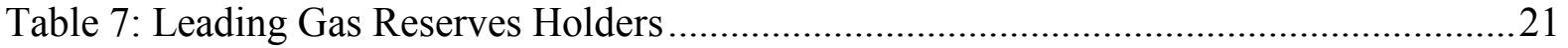

Table 8: Gaffney Cline \& Associates Survey Results of South Yolotan and Yashlar Gas

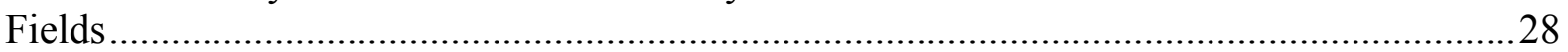

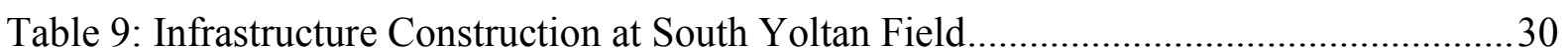

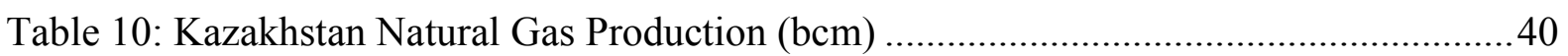

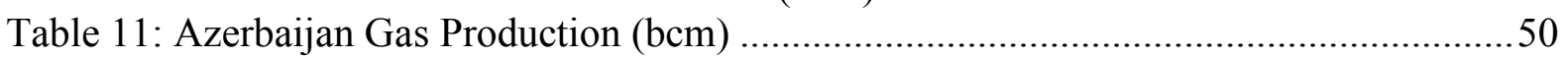

Table 12: Azerbaijan: offshore Caspian projects at pre-development stage...........................53

Table 13: Selected Economic Indicators for Uzbekistan, Russia and Ukraine........................57

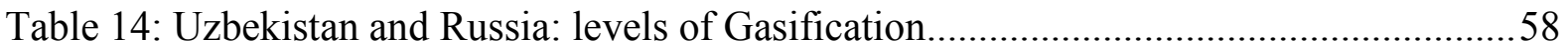

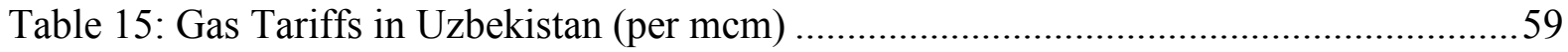




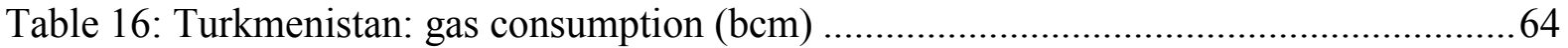

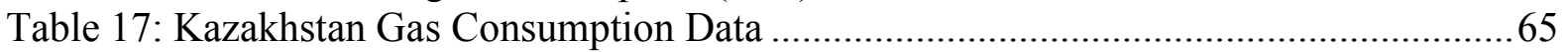

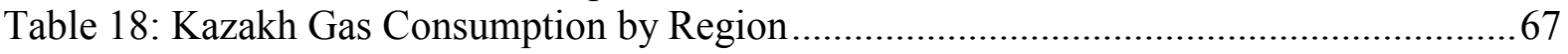

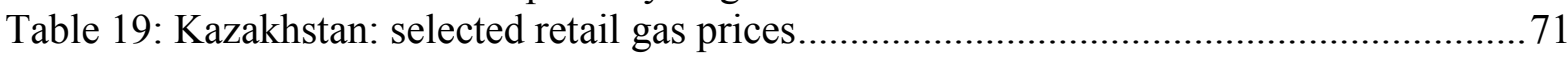

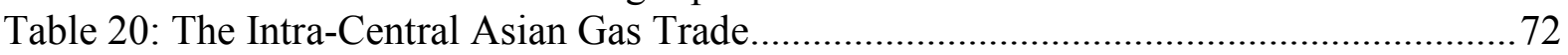

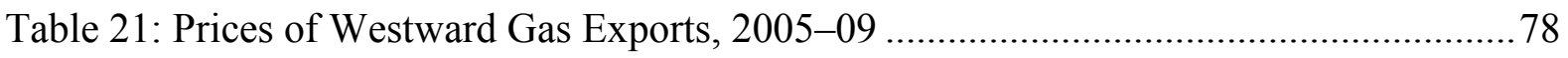

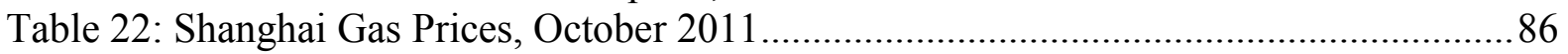

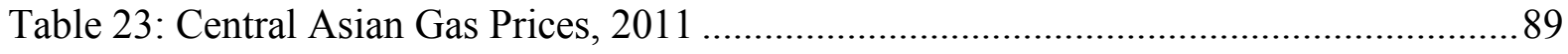

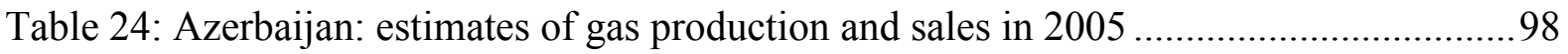

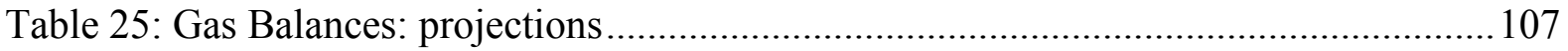

Table 26: Central Asian and Caspian Gas Exports 2011-20: projections .............................. 109

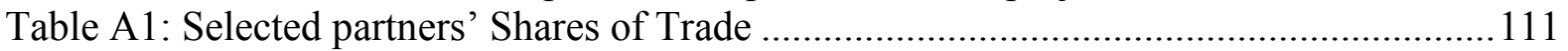

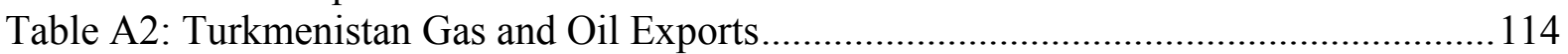

Table A3: Turkmenistan GDP and Export Revenues: IMF statistics ................................. 115

Table A4: Turkmenistan GDP: IMF and EBRD views compared .................................... 116

Table A5: Turkmenistan: foreign exchange reserves and external debts ............................ 117

Table A6: Production from Uzbekistan Projects with Gazprom Participation, 2010 ............ 119

\section{Maps}

Map 1: Central Asian and Caspian Region..........................................

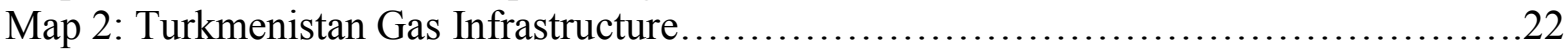

Map 3: Uzbekistan Gas Infrastructure.................................................. 31

Map 4: Kazakhstan Gas Infrastructure .......................................... 42

Map 5: Azerbaijan Gas Infrastructure............................................... 51

Map 6: Kazakhstan Regions..................................................66

\section{Figures}

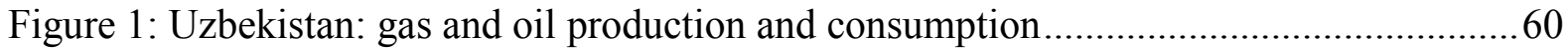

Figure 2: Estimates of costs of gas delivered to Moscow, 2020 ........................................ 91 
Map 1: Central Asian and Caspian Region

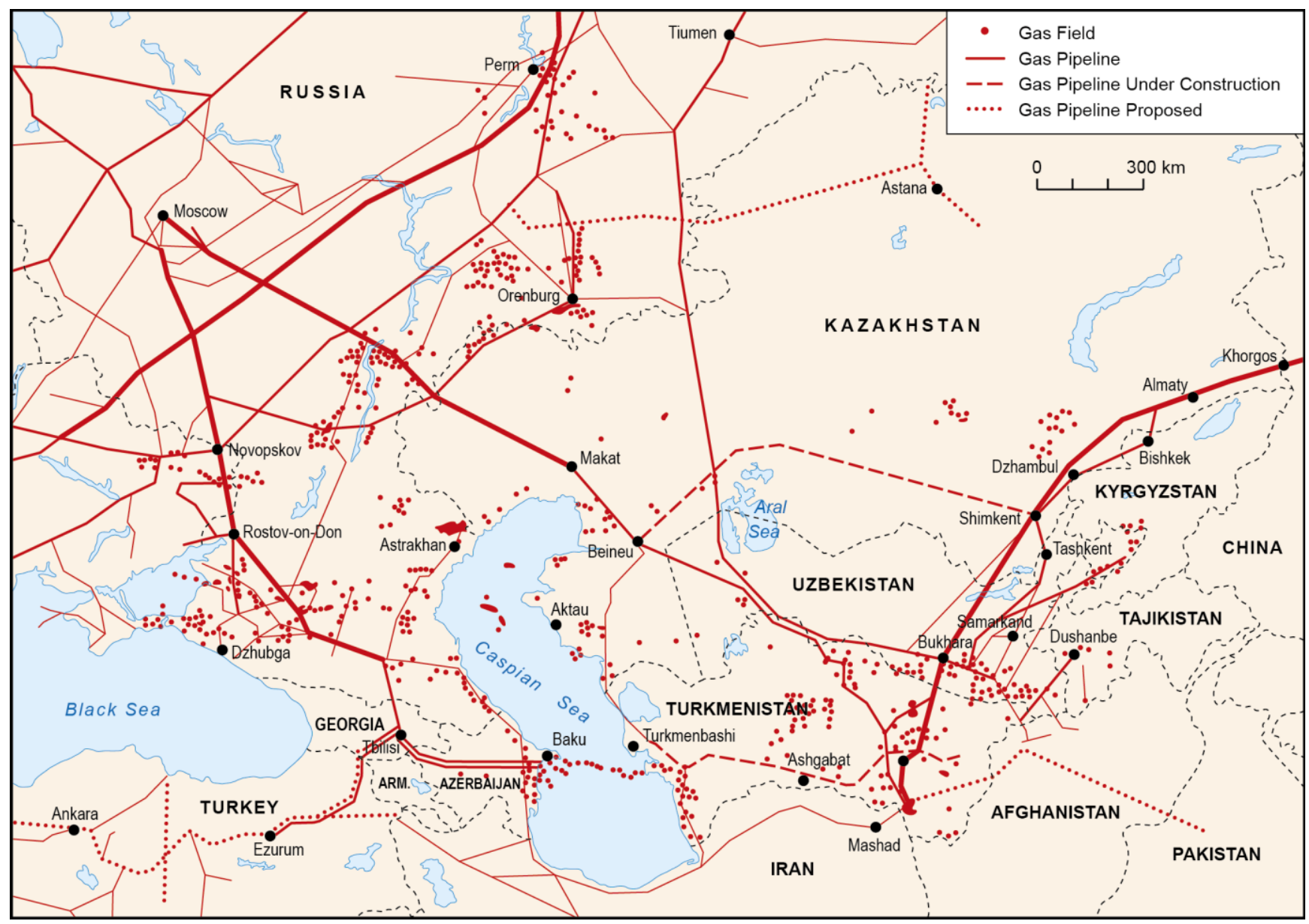

\section{Introduction: gas in the Central Asian/Caspian energy balance}

The confirmation of Turkmenistan as a world-class natural gas reserves holder - with proven and probable reserves of around half the size of Russia's - has refocused the international gas industry's attention on the Central Asian and Caspian region. The completion of the Turkmenistan-China pipeline has made the region an important supplier to the fast-growing Chinese market. The Shah Deniz II project in Azerbaijan, due to come on stream in 2017, will supply a direct export route from the region to Europe for the first time. This paper examines the way that these new export markets are likely to develop, and the relationship between these, domestic markets and the traditional export trade to and through Russia. Economic, social and political contexts - that may prove decisive in determining whether, when and how gas resources are produced - are surveyed.

The paper focuses on the four main gas producers in the region: Turkmenistan, Uzbekistan, Kazakhstan and Azerbaijan. For context, Russian and Iranian production are mentioned, and in respect of transit and consumption there is some discussion of the four small non-gasproducing countries in the region, Tajikistan, Kyrgyzstan, Georgia and Armenia. An examination of the elements of supply and demand will lead to conclusions, the most important of which are:

- Turkmenistan's agreements with China provide a framework for the development of South Yolotan, now confirmed as the second largest gas field in the world, and other 
resources. The target set by the Chinese and Turkmen presidents, of $65 \mathrm{bcm} / \mathrm{year}$ exports, is achievable, although field development and infrastructure development for these volumes may take until the end of the decade to complete. This target implies a total of up to $110 \mathrm{bcm} /$ year production all together by Turkmenistan $(65 \mathrm{bcm}$ for China, e.g. up to $10 \mathrm{bcm}$ for Iran, $11 \mathrm{bcm}$ to and through Russia, $4 \mathrm{bcm}$ for Central Asian countries and $20 \mathrm{bcm}$ for the domestic market).

- Even if Turkmenistan's total production and exports were lower than that, it would still probably earn revenues in excess of spending requirements. While Turkmen government policy is to increase gas production and exports to underpin a "golden age" for the country, this is likely to be achieved mainly on the basis of exports to China. This is the policy that Turkmenistan is following in practice, whatever is occasionally said about higher production levels.

- For either a European or south Asian export route to be opened up from Turkmenistan, the government would need (i) buyers in these locations prepared to commit to the investments and long-term contracts required and take all transport and financial risk from the Turkmen border, and (ii) a set of compelling reasons to tackle the difficulties involved. These are not present now.

- Exports to and through Russia from Central Asia are currently conducted at European netback prices, with the gas delivered mainly to Ukraine and central Europe. These exports were sharply reduced in 2009, are unlikely to be increased again, and could be further reduced to the extent that market forces, rather than political relationships, decide. Central Asian gas would struggle to compete on price with Russian-produced gas in a liberalised Russian market.

- With European demand low, Russian exports to Europe likely to remain at a reduced level, and Turkmen exports to Iran subject to possible decline due to the development of Iranian domestic gas infrastructure, the worst-case scenario for Turkmenistan is that it will end up becoming the supplier of last resort to these markets. This would make it more dependent than it wishes to be on Chinese purchases - and vulnerable to demands from China that prices, which are among the highest for imported gas, be renegotiated.

- Uzbekistan, currently Central Asia's largest producer, consumes most of its gas production. The near-crisis conditions in its domestic energy sector - caused by the poor state of distribution infrastructure, the tension between energy-saving policies and energy-intensive industrial development policies, the substitution of oil products with gas - make the future trajectory of Uzbek consumption very difficult to project. But it is unlikely to fall by much.

- Another uncertainty in Uzbekistan is the tension between high domestic consumption and exports. New fields are being developed, but mostly in partnership with foreign companies who have collectively set their sights on $17 \mathrm{bcm} /$ year of incremental exports by the end of this decade. If this new gas is to be exported, then either Uzbekistan will need to replace the output of fields in natural decline with other new resources, or cut consumption, or find other solutions. Uzbekistan is likely first to cede its Central Asian export trade to Turkmenistan, and may then be compelled to prioritise energy-saving measures over energy-intensive industrial policies. 
- Kazakhstan will raise gas production, particularly from the Kashagan field, and is likely to produce more than $25 \mathrm{bcm} /$ year of sales gas by the end of the decade. However consumption will also increase, due to government policies on associated gas utilisation and gasification - although the government's target of $24 \mathrm{bcm} /$ year consumption may not be met by 2020 .

- Apart from the opening of the Chinese route, the other significant change that is likely in the region in this decade is the growth of Azeri exports to Turkey (to $13 \mathrm{bcm} / \mathrm{year}$ ) and the start-up of Azeri exports, from the Shah Deniz II project, to Europe (10bcm/year). As well as Shah Deniz II there are several Azeri offshore prospects that, subject to the success of exploration, could start producing by 2020 , but most will probably start after that, given upstream infrastructure constraints.

Gas in the energy balance

There are marked differences between the part played by gas in the energy sectors, and economies, of the four producer countries. These are highlighted in Table 1, which presents the IEA's data on their energy balances in abbreviated form. ${ }^{1}$

Table 1: Energy Balances (Abbreviated) 2009, in 000 tonnes of oil equivalent, net calorific value basis

\begin{tabular}{|l|r|r|r|r|r|r|r|r|}
\hline TURKMENISTAN & TOTAL & $\begin{array}{l}\text { Coal } \\
\text { \& } \\
\text { peat }\end{array}$ & $\begin{array}{l}\text { Crude } \\
\text { oil }\end{array}$ & $\begin{array}{l}\text { Oil } \\
\text { products }\end{array}$ & Gas & $\begin{array}{l}\text { Hydro } \\
\text { \& } \\
\text { renw'bls }\end{array}$ & $\begin{array}{l}\text { Electri- } \\
\text { city }\end{array}$ & Heat \\
\hline Production & $\mathbf{4 0 9 0 4}$ & 0 & 9841 & 0 & 31063 & 0 & 0 & 0 \\
\hline Imports & $\mathbf{8 8}$ & 0 & 0 & 88 & 0 & 0 & 0 & 0 \\
\hline Exports & $\mathbf{- 2 1 4 0 9}$ & 0 & -2010 & -3270 & - & 0 & -135 & 0 \\
\hline Stock changes, etc & $\mathbf{0}$ & 0 & 0 & 0 & 0 & 0 & 0 & 0 \\
\hline $\begin{array}{l}\text { Total primary energy } \\
\text { supply }\end{array}$ & $\mathbf{1 9 5 8 4}$ & $\mathbf{0}$ & $\mathbf{7 8 3 1}$ & $\mathbf{- 3 1 8 2}$ & $\mathbf{1 5 0 7 0}$ & $\mathbf{0}$ & $\mathbf{- 1 3 5}$ & $\mathbf{0}$ \\
\hline Electricity and heat plants & $\mathbf{- 4 5 6 4}$ & 0 & 0 & 0 & -6122 & 0 & 1374 & 184 \\
\hline $\begin{array}{l}\text { Refineries \& other } \\
\text { transf'mn }\end{array}$ & $\mathbf{- 3 4 4 7}$ & 0 & -7831 & 6548 & -1725 & 0 & -440 & 0 \\
\hline $\begin{array}{l}\text { Final consumption } \\
\text { (industry, transport, } \\
\text { residential, etc) }\end{array}$ & $\mathbf{- 1 1 5 7 3}$ & 0 & 0 & -3366 & -7223 & 0 & -800 & -184 \\
\hline
\end{tabular}

\footnotetext{
${ }^{1}$ The row "Refineries and other transformation" includes energy industry own use and losses. (Gas produced and reinjected in Kazakhstan, and also possibly in Uzbekistan, is wrongly included in that category by the IEA, making it unfeasibly large.) That row also includes some coal transformation in Kazakhstan. I have not included any breakdown of final consumption, and I have merged all hydro and renewables in one column: this is all hydro in Uzbekistan and Azerbaijan, and four-fifths hydro in Kazakhstan. Simon. I checked addition in the table and there are things wrong where I've highlighted in red - Uzbek and Azer..
} 


\begin{tabular}{|c|c|c|c|c|c|c|c|c|}
\hline UZBEKISTAN & TOTAL & $\begin{array}{l}\text { Coal } \\
\& \\
\text { peat }\end{array}$ & $\begin{array}{l}\text { Crude } \\
\text { oil }\end{array}$ & $\begin{array}{l}\text { Oil } \\
\text { products }\end{array}$ & Gas & $\begin{array}{l}\text { Hydro } \\
\& \\
\text { renw'bls }\end{array}$ & $\begin{array}{l}\text { Electri- } \\
\text { city }\end{array}$ & Heat \\
\hline Production & 60694 & 1288 & 4804 & 0 & 53799 & 802 & 0 & 0 \\
\hline Imports & 1756 & 70 & 4 & 0 & 686 & 0 & 996 & 0 \\
\hline Exports & -13641 & -13 & 0 & -281 & $\begin{array}{r}- \\
12344\end{array}$ & 0 & -1003 & 0 \\
\hline Stock changes, etc & $\mathbf{0}$ & 0 & 0 & 0 & 0 & 0 & 0 & 0 \\
\hline $\begin{array}{l}\text { Total primary energy } \\
\text { supply }\end{array}$ & 48809 & 1345 & 4808 & -281 & 42141 & 802 & -7 & $\mathbf{0}$ \\
\hline Electricity and heat plants & -8430 & -888 & 0 & -320 & 13093 & -802 & 4292 & 2383 \\
\hline $\begin{array}{l}\text { Refineries \& other } \\
\text { transf'mn }\end{array}$ & -4516 & -15 & -4726 & 4153 & -3183 & 0 & -745 & 0 \\
\hline $\begin{array}{l}\text { Final consumption } \\
\text { (industry, transport, } \\
\text { residential, etc) }\end{array}$ & -35863 & -442 & -81 & -3551 & 25865 & 0 & -3540 & -2383 \\
\hline KAZAKHSTAN & TOTAL & $\begin{array}{l}\text { Coal } \\
\& \\
\text { peat }\end{array}$ & $\begin{array}{l}\text { Crude } \\
\text { oil }\end{array}$ & $\begin{array}{l}\text { Oil } \\
\text { products }\end{array}$ & Gas & $\begin{array}{l}\text { Hydro } \\
\& \\
\text { renw'bls }\end{array}$ & $\begin{array}{l}\text { Electri- } \\
\text { city }\end{array}$ & Heat \\
\hline Production & 145814 & 44282 & 77973 & 0 & 22811 & 749 & 0 & 0 \\
\hline Imports & 10195 & 479 & 6059 & 1703 & 1807 & 0 & 147 & 0 \\
\hline Exports & -90264 & $\begin{array}{r}- \\
13220\end{array}$ & $\begin{array}{r}- \\
65421\end{array}$ & -5869 & -5548 & 0 & -205 & 0 \\
\hline Stock changes, etc & 90 & 16 & 45 & -94 & 123 & 0 & 0 & 0 \\
\hline $\begin{array}{l}\text { Total primary energy } \\
\text { supply }\end{array}$ & 65835 & 31557 & 18655 & -4260 & 19192 & 749 & -58 & $\mathbf{0}$ \\
\hline Electricity and heat plants & -8760 & $\begin{array}{r}- \\
21006\end{array}$ & -288 & -441 & -2539 & -592 & 6769 & 9336 \\
\hline $\begin{array}{l}\text { Refineries \& other } \\
\text { transf'mn }\end{array}$ & -19648 & -3592 & $\begin{array}{r}- \\
18367\end{array}$ & 12845 & -8870 & 0 & -555 & -1109 \\
\hline $\begin{array}{l}\text { Final consumption } \\
\text { (industry, transport, } \\
\text { residential, etc) }\end{array}$ & -37426 & -6960 & 0 & 8143 & -7783 & -157 & -6156 & -8227 \\
\hline AZERBAIJAN & TOTAL & $\begin{array}{l}\text { Coal } \\
\& \\
\text { peat }\end{array}$ & $\begin{array}{l}\text { Crude } \\
\text { oil }\end{array}$ & $\begin{array}{l}\text { Oil } \\
\text { products }\end{array}$ & Gas & $\begin{array}{l}\text { Hydro } \\
\text { \& } \\
\text { renw'bls }\end{array}$ & $\begin{array}{l}\text { Electri- } \\
\text { city }\end{array}$ & Heat \\
\hline Production & 64559 & 0 & 50659 & 0 & 13660 & 199 & 0 & 40 \\
\hline Imports & 46 & 0 & 0 & 37 & 0 & 0 & 9 & 0 \\
\hline Exports & -51910 & 0 & 44553 & -2415 & -4909 & 0 & -33 & 0 \\
\hline Stock changes, etc & -727 & 0 & 128 & -328 & -526 & 0 & 0 & 0 \\
\hline $\begin{array}{l}\text { Total primary energy } \\
\text { supply }\end{array}$ & 11968 & $\mathbf{0}$ & 6234 & -2706 & 8225 & 199 & -23 & 40 \\
\hline Electricity and heat plants & -2603 & 0 & 0 & -131 & -4233 & -199 & 1623 & 337 \\
\hline $\begin{array}{l}\text { Refineries \& other } \\
\text { transf'mn }\end{array}$ & -2791 & 0 & -6234 & 5378 & -1314 & 0 & -535 & -87 \\
\hline $\begin{array}{l}\text { Final consumption } \\
\text { (industry, transport, } \\
\text { residential, etc) }\end{array}$ & -6574 & 0 & 0 & -2541 & -2678 & 0 & -1066 & -290 \\
\hline
\end{tabular}

Source: IEA energy balances, 2009 
Turkmenistan is the leading gas exporter in the region. Unfortunately, Table B does not reflect this well, because it uses IEA data for 2009, the latest available, and in that year production and exports were both cut to their lowest level in post-Soviet times, due to the cessation of Russian purchases of Turkmen gas for most of that year; since then, Russian purchases have stayed low, but sales to China have risen consistently. So both production and exports are likely to return to previous levels. The volumes produced and exported in 2008, although generally higher than in most other recent years, are more representative than those for 2009. Gas production in 2008 was nearly twice as high as in 2009, and exports nearly three times as high. This is shown in Table 2, which compares some key data for those two years:

Table 2: Turkmenistan: Gas and Other Energy

\begin{tabular}{|l|l|l|}
\hline 000 tonnes of oil equivalent, net calorific value basis & $\mathbf{2 0 0 9}$ & $\mathbf{2 0 0 8}$ \\
\hline Gas production & 31063 & 57404 \\
\hline Gas exports & 15993 & 43685 \\
\hline Total production of energy & 40904 & 66358 \\
\hline Total exports of energy & 21409 & 48217 \\
\hline
\end{tabular}

Source: IEA energy balances

Indicators of energy efficiency and gas efficiency, in Table 3, show that the Central Asian and Caspian countries use large amounts of gas considering the size and living standard of their populations. Gas consumption per head in Uzbekistan, the largest gas consumer in the region, is in the same range as in the UK and the Netherlands, despite the much lower standard of living. The underlying problem is evident from the columns in the table that compare Total Primary Energy Supply to population and to GDP. Uzbekistan and Azerbaijan use substantially less energy per person than Kazakhstan, Turkmenistan, Russia or richer western European countries, whereas the amount of energy consumed per unit of GDP is substantially higher in all the former Soviet countries (apart from Azerbaijan) than in the western European countries.

Table 3: Energy Efficiency and Gas Efficiency Compared

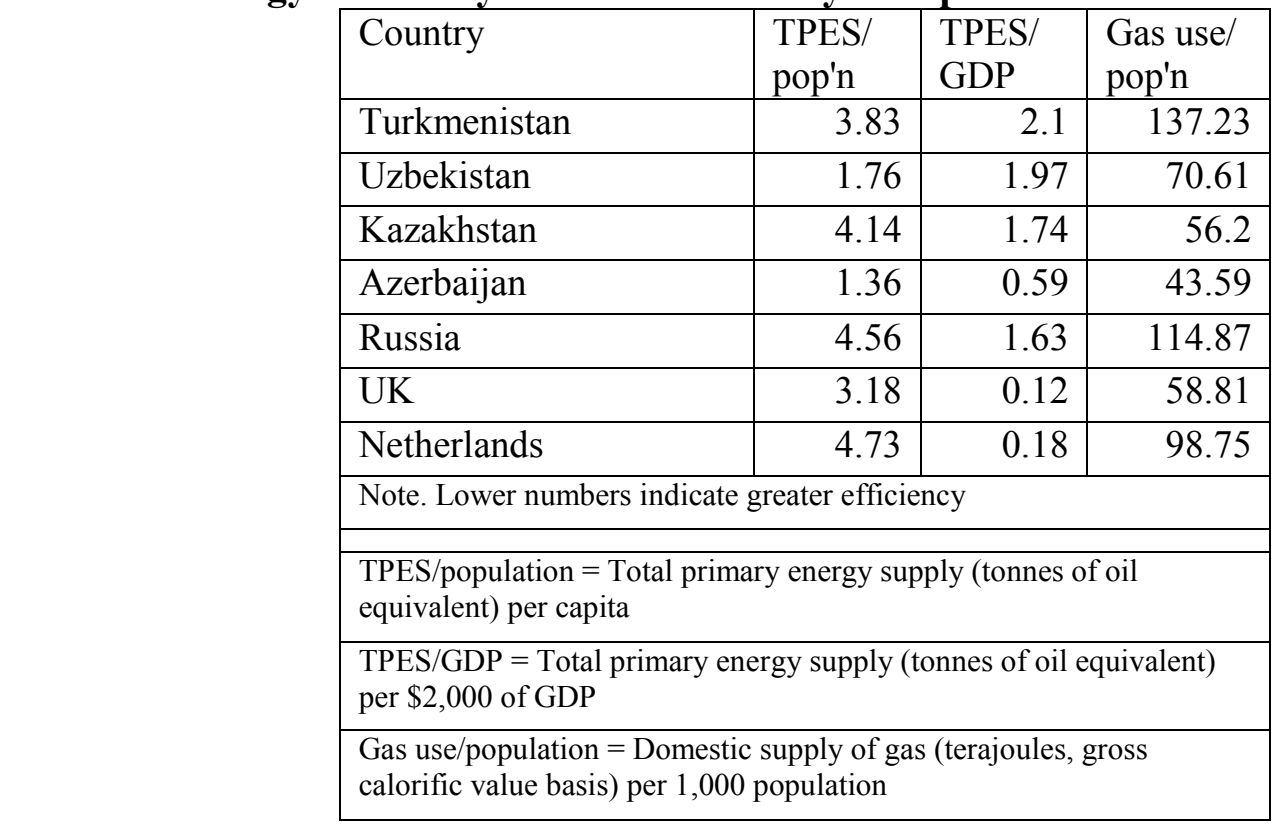

Source: IEA energy balances and natural gas information; author's calculations 
It is useful to compare Turkmenistan with Uzbekistan. Since the mid 1990s, the two countries have produced similar volumes of gas, between $55 \mathrm{bcm}$ and $70 \mathrm{bcm}$ annually. Although Turkmen production fell sharply in 2009-11, as Russian purchases were cut, it is likely to return to its previous level within the next two to three years, as exports to China rise. From similar production volumes, Uzbekistan, with a population rising from 20-24 million in the 1990 s to 29.1 million now, ${ }^{2}$ has always consumed most of what it has produced; Turkmenistan, with a population of about 5 million, has always exported most of its gas.

Turkmenistan's economy and state finances are dominated by gas export revenues in a way that the other producers' economy and finances are not. Natural gas has historically accounted for up to two thirds of export revenues; the only other energy produced is a small amount of oil, and Turkmenistan probably earns from its oil products exports about one-third of what it earns from gas. (See Appendix 3 on Turkmenistan's finances.) Gas is also predominant in Turkmenistan's domestic energy consumption. This is evident from Table 1 (the row "total primary energy supply"): the entire electricity and heat sector runs on gas, and gas accounts for most energy supplied to industry and the residential sector. Turkmenistan has gas for export not because its domestic consumption is more diversified than Uzbekistan's, but because its population is so much smaller.

It is Uzbekistan's heavy dependence on gas for domestic consumption that is the key constraint on its role as an exporter. This is a problem it shares with many producing countries, those in the Gulf region in particular. ${ }^{3}$ As Table 1 shows, gas accounts for about nine-tenths of the energy produced in Uzbekistan, accompanied only by small volumes of coal, oil and hydro electricity. Table 1 also shows that gas accounts for almost all of the fuel for Uzbekistan's electricity and heat plants (13 million boe), compared to 2 million boe from all other sources in 2009), and for nearly 26 million boe of the 36 million boe of final energy consumption in 2009. Table 3 shows that Uzbekistan's consumption of gas per head is substantially higher than Kazakhstan's or Azerbaijan's - and although Turkmenistan's is higher still, it is sufficiently well endowed that it has surplus gas for export that Uzbekistan does not.

Uzbekistan entered the post-Soviet period already highly dependent on gas, and its economic policy since then, which has prioritised self-sufficiency and import substitution, has worked against any diversification of energy supply. Uzbekistan's demand for gas could increase - or at least, energy-saving efforts could be cancelled out by fresh sources of demand - in the next few years. Uzbekistan has begun to import oil products, and the government is hoping to use gas to substitute for these. This significant problem with Uzbekistan's energy balance, will be discussed below in section 4.1. Uzbekistan's gas export potential has always been strongly constrained by its high, and very inefficient, domestic consumption, and this paper will argue that it will remain the case at least for the rest of this decade.

In Kazakhstan, gas is less important than oil as an export commodity, and less important than coal as a domestic energy source - although government policy is directed at expanding its role in the economy. As Table 1 shows, Kazakhstan produces more than twice as much energy as any of the three other countries (146 million boe in 2009). Of this, more than half (78 million boe) is crude oil, and almost one third (44 million boe) is coal. Six-sevenths of the crude oil and nearly one third of the coal is exported - and economically, Kazakhstan is heavily dependent on oil export revenues. The gas produced amounts to only about half the

\footnotetext{
${ }^{2}$ Population estimates by national statistical agency of Uzbekistan. See $<$ http://www.stat.uz/uz/demographic/>

${ }^{3}$ See, for example, Laura El-Katiri, "Energy sustainability in the Gulf”, Gulf Oil Review, November 2012, p. 3.
} 
energy content of the coal ( 23 million boe), but much of what is counted by the IEA is reinjected or flared. Gas production and exports could both increase in the next decade, but this paper suggests that this will depend largely on (i) the pace of upstream investment and development, and (ii) the course taken by the controversy over associated gas, and by the government's attempt to raise domestic gas consumption.

In Azerbaijan, gas is less important than oil as an export commodity, but its importance will grow steadily in the coming years. As Table 1 shows, crude oil accounts for more than three quarters of the energy produced and more than five sixths of the energy exported; gas accounts for nearly all of what remains, supplemented by a small volume of hydro electricity. Gas already plays an important part in the domestic economy since, unlike Kazakhstan, Azerbaijan has no coal. The electricity and heat sector is overwhelmingly fuelled by gas and it has a slightly larger share than oil products of final consumption (in industry, transport and the residential sector, etc). Gas's importance will grow for reasons to do with Azerbaijan's hydrocarbon reserves: its oil production is estimated to have peaked, and the government aims to raise gas production and exports as one means to replace oil export revenues as output declines.

Table 4 shows the four countries' gas balances, starting from 2005, with the author's estimates for 2012 and 2013.

There are some key points to draw to the reader's attention, as follows. On production, an attempt has been made to show the difference between the total volume of gas produced (including that reinjected or flared) and the volume available as sales gas. Industry practice, and standard practice of the IEA and most other statistical agencies, is not to count reinjected and flared gas as produced. But practice in post-Soviet countries - and the Soviet Union before them - has sometimes been the opposite. This has led to confusion, particularly in Kazakhstan, where such a large proportion of gas is associated gas produced with oil. Azerbaijan's statistical agency has always made the difference clear; Kazakhstan's has begun to do so too, and this is reflected in Table 4. The numbers given for reinjected and flared gas in Uzbekistan and Turkmenistan are estimates, in the latter case reflecting some information in the IEA's statistics. (For information on the data used, see Appendix 1.)

A final point to be made by way of introduction is that while the Central Asian-Caspian region's natural gas resources are ample, they generally have a high hydrogen sulphide content. Concentrations of hydrogen sulphide greater than 300 parts per million are lethal, and so it has to be extracted immediately after production, to meet grid specifications. This adds to processing costs and produces a surfeit of sulphur byproduct. 
Table 4: Gas Balances

\begin{tabular}{|c|c|c|c|c|c|c|c|c|}
\hline \multicolumn{9}{|l|}{ billions of cubic metres (bcm) } \\
\hline & 2006 & 2007 & 2008 & 2009 & 2010 & 2011 & $\begin{array}{l}\text { 2012, } \\
\text { proj. }\end{array}$ & $\begin{array}{l}2013, \\
\text { proj. }\end{array}$ \\
\hline \multicolumn{9}{|l|}{ Turkmenistan } \\
\hline Production (total) & 62.0 & 63.8 & 69.5 & 35.9 & 41.2 & 54.1 & 59.3 & 64.6 \\
\hline Reinjected \& flared & 0.5 & 0.6 & 2.9 & 1.1 & 2.0 & 2.0 & 2.0 & 2.0 \\
\hline Production (sales gas) & 61.5 & 63.2 & 66.6 & 34.8 & 39.2 & 52.1 & 57.3 & 62.6 \\
\hline Domestic consumption & 14.1 & 14.4 & 17.2 & 16.0 & 17.0 & 17.0 & 17.5 & $\mathbf{1 7 . 5}$ \\
\hline Export (total) & 47.4 & 48.8 & 49.4 & 18.8 & 22.2 & 35.1 & 39.8 & 45.1 \\
\hline Export to/through Russia & 39.3 & 39.8 & 42.3 & 11.8 & 10.7 & 11.2 & 11 & 11 \\
\hline Export to Iran & 6.3 & 6.2 & 7.1 & 7 & 8 & 8 & 8 & 8 \\
\hline Export to Kazakhstan & 1.8 & 2.8 & 0 & 0 & 0 & 0.4 & 0.7 & 1 \\
\hline Export to Tajikistan & 0 & 0 & 0 & 0 & 0 & 0 & 0.1 & 0.1 \\
\hline Export to China & 0 & 0 & 0 & 0 & 3.5 & 15.5 & 20 & 25 \\
\hline Total & 61.5 & 63.2 & 66.6 & 34.8 & 39.2 & 52.1 & 57.3 & 62.6 \\
\hline \multicolumn{9}{|l|}{ Uzbekistan } \\
\hline Production (total) & 62.7 & 65.2 & 68.6 & 63.8 & 61.7 & 57.7 & 56.9 & 56.0 \\
\hline Reinjected \& flared & 2.5 & 2.5 & 2.5 & 2.5 & 2.5 & 2.5 & 2.5 & 2.5 \\
\hline Production (sales gas) & 60.2 & 62.7 & 66.1 & 61.3 & 59.2 & 55.2 & 54.4 & 53.5 \\
\hline Domestic consumption & 47.6 & 48 & 50.1 & 45 & 44.4 & 44.3 & 44.0 & 43.5 \\
\hline Export (total) & 12.6 & 14.7 & 16.0 & 16.3 & 14.8 & 10.9 & 10.4 & $\mathbf{1 0 . 0}$ \\
\hline Export to/through Russia & 9 & 10.3 & 11.5 & 13.1 & 11.4 & 8.0 & 7.0 & 7.0 \\
\hline Export to Kazakhstan & 2.3 & 3 & 3.3 & 2.3 & 2.5 & 2.1 & 1.8 & 1.5 \\
\hline Export to Kyrgyzstan/Tajikistan & 1.3 & 1.4 & 1.2 & 0.9 & 0.9 & 0.8 & 0.6 & 0.5 \\
\hline Export to China & 0 & 0 & 0 & 0 & 0 & 0 & 1.0 & 1.0 \\
\hline Total & 60.2 & 62.7 & 66.1 & 61.3 & 59.2 & 55.2 & 54.4 & $\mathbf{5 3 . 5}$ \\
\hline \multicolumn{9}{|l|}{ Kazakhstan } \\
\hline Production (total) & 26.4 & 29.6 & 32.9 & 35.9 & 37.26 & 39.5 & 40 & 40 \\
\hline Reinjected \& flared & 13.6 & 16.1 & 17 & 17.6 & 18.66 & 21 & 21.5 & 21.5 \\
\hline Production (sales gas) & 12.8 & 13.5 & 15.9 & 18.3 & 18.6 & 18.5 & 18.5 & $\mathbf{1 8 . 5}$ \\
\hline Import & 11 & 7.8 & 6.2 & 3.2 & 4.5 & 4.5 & 4.7 & 4.7 \\
\hline Import from Russia & 6.9 & 2.0 & 2.9 & 0.9 & 2.0 & 2.0 & 2.0 & 2.0 \\
\hline Import from Turkmenistan & 1.8 & 2.8 & 0 & 0 & 0 & 0.4 & 0.7 & 1 \\
\hline Import from Uzbekistan & 2.3 & 3 & 3.3 & 2.3 & 2.5 & 2.1 & 1.8 & 1.5 \\
\hline Total & 23.8 & 21.3 & 22.1 & 21.5 & 23.1 & 23.0 & 23.2 & 23.2 \\
\hline Domestic consumption & 9.4 & 6.1 & 7.1 & 11.4 & 10.7 & 11.0 & 11.7 & 12.2 \\
\hline Export (total) & 14.4 & 15.2 & 15 & 10.1 & 12.4 & 12.0 & 11.5 & 11.0 \\
\hline Export to/through Russia & 14.3 & 15.2 & 15 & 10.1 & 12.4 & 11.9 & 11.4 & 10.9 \\
\hline Export to Kyrgyzstan & 0.1 & 0 & 0 & 0 & 0 & 0.1 & 0.2 & 0.3 \\
\hline Total & 23.8 & 21.3 & 22.1 & 21.5 & 23.1 & 23.0 & 23.2 & 23.2 \\
\hline
\end{tabular}




\begin{tabular}{|l|r|r|r|r|r|r|r|r|r|}
\hline Azerbaijan & 2006 & 2007 & 2008 & 2009 & 2010 & 2011 & $\begin{array}{c}2012, \\
\text { proj }\end{array}$ & $\begin{array}{c}2013, \\
\text { proj }\end{array}$ \\
\hline Production (total) & 9.1 & 16.9 & 23.4 & 23.6 & 26.3 & 27.5 & 28 & 28 \\
\hline Reinjected \& flared & 3.0 & 6.1 & 7.1 & 7.3 & 9.6 & 8 & 7.5 & 7.5 \\
\hline Production (sales gas) & $\mathbf{6 . 1}$ & $\mathbf{1 0 . 8}$ & $\mathbf{1 6 . 3}$ & $\mathbf{1 6 . 3}$ & $\mathbf{1 6 . 7}$ & $\mathbf{1 9 . 5}$ & $\mathbf{2 0 . 5}$ & $\mathbf{2 0 . 5}$ \\
\hline Import & $\mathbf{4 . 4}$ & $\mathbf{0 . 5}$ & $\mathbf{0 . 5}$ & $\mathbf{0 . 5}$ & $\mathbf{0 . 5}$ & $\mathbf{0 . 5}$ & $\mathbf{0 . 5}$ & $\mathbf{0 . 5}$ \\
\hline Import from/through Russia & 4.4 & 0 & 0 & 0 & 0 & 0 & 0 & 0 \\
\hline Import from Iran (swaps) & 0 & 0.5 & 0.5 & 0.5 & 0.5 & 0.5 & 0.5 & 0.5 \\
\hline Total & $\mathbf{1 0 . 5}$ & $\mathbf{1 1 . 3}$ & $\mathbf{1 6 . 8}$ & $\mathbf{1 6 . 8}$ & $\mathbf{1 7 . 2}$ & $\mathbf{2 0}$ & $\mathbf{2 1}$ & $\mathbf{2 1}$ \\
\hline Domestic consumption & $\mathbf{1 0 . 4}$ & $\mathbf{8 . 7}$ & $\mathbf{8 . 9}$ & $\mathbf{8 . 5}$ & $\mathbf{7 . 8}$ & $\mathbf{1 0 . 1}$ & $\mathbf{1 0 . 6}$ & $\mathbf{1 0 . 6}$ \\
\hline Export (total) & $\mathbf{0 . 1}$ & $\mathbf{2 . 6}$ & $\mathbf{7 . 9}$ & $\mathbf{8 . 3}$ & $\mathbf{9 . 4}$ & $\mathbf{9 . 9}$ & $\mathbf{1 0 . 4}$ & $\mathbf{1 0 . 4}$ \\
\hline Export to/through Russia & 0 & 0 & 0 & 0 & 0.8 & 1.5 & 2.0 & 2.0 \\
\hline Export to Iran (swaps + fuel gas) & 0.1 & 0.6 & 0.6 & 0.6 & 0.6 & 0.6 & 0.6 & 0.6 \\
\hline Export to Georgia & 0 & 0.8 & 1 & 1.5 & 1.5 & 1.5 & 1.5 & 1.5 \\
\hline Export to/through Turkey & 0 & 1.2 & 6.3 & 6.3 & 6.3 & 6.3 & 6.3 & 6.3 \\
\hline Total & $\mathbf{1 0 . 5}$ & $\mathbf{1 1 . 3}$ & $\mathbf{1 6 . 8}$ & $\mathbf{1 6 . 8}$ & $\mathbf{1 7 . 2}$ & $\mathbf{2 0}$ & $\mathbf{2 1}$ & $\mathbf{2 1}$ \\
\hline
\end{tabular}

Sources:

Turkmenistan. Production: estimates, with reference to IEA energy balances. Consumption: extrapolated from IEA balances. Exports: Gazprom annual reports, Petrochina, press, industry information

Uzbekistan. Production: US EIA, estimates. Consumption: EIA, estimates, Exports: Gazprom annual reports, CIS customs statistics, press, estimates

Kazakhstan. Production: Table G below. Consumption: Tables H and K below. Exports and imports: Gazprom, Kazrosgaz and other company information; Kazakhstan statistical agency; CIS statistics; estimates

Azerbaijan. Production: Socar; Azerbaijan statistical committee. Exports and imports: company and industry information; CIS statistics; estimates. 


\section{Economic, political and social contexts}

\section{Some historical and economic background}

Even though more than two decades have passed since the break-up of the Soviet Union, the origin of the Central Asian and Caspian gas producers as Soviet republics, both geographically and economically, needs to be borne in mind. While all the peoples in the region have a rich history and culture stretching back many centuries, there were no sovereign states bearing the names of the four states under discussion, and occupying the same territory, prior to the first world war; broadly speaking, they all took on their current names and borders as Soviet republics during the 1920s. The Soviet Union shaped their economic development. They were in the first place suppliers of raw materials to industry in central Russia and the Urals: Kazakhstan supplied coal, minerals and wheat; Uzbekistan and Turkmenistan produced cotton and textiles, until natural gas production took off in the 1950s and 1970s respectively and Uzbek gold production began; Azerbaijan supplied, above all, oil. The region's natural resources were developed in line with the requirements of the Soviet economy. This is obvious to all who know the gas sector, the pipeline infrastructure for which fanned out from Moscow and other industrial centres, leaving big gaps within the producing countries - e.g. between west and east in both Kazakhstan and Turkmenistan - that remain to this day. On the other hand, the Soviet Union left interdependencies between republics that might never have developed between politically separate states, such as the gas-water-electricity connections between Tajikistan and Uzbekistan.

The collapse of the Soviet Union suddenly and unexpectedly forced the Central Asian and Caspian states not only to develop political systems and social policies from scratch, but also to devise independent economic strategies. Each of them has adopted distinct approaches e.g. to the management of natural resources and to the state's role in the economy. But some changes have applied across the region. Perhaps the most significant trend is that the Central Asian and Caspian states' economic ties with Russia, and with each other, have loosened, while those with other partners - China and other Asian countries for Central Asia, Turkey and European countries for Azerbaijan - have grown. ${ }^{4}$ Even Kazakhstan, which has retained the closest relationship with Russia - and formed a Customs Union together with Russia and Belarus in 2010, and is working with those countries to establish a Eurasian Union with a view to further integration - did more than twice as much trade with China as with Russia in 2011. China became Turkmenistan's largest trading partner in 2011, accounting for more than one third of trade, in large part due to rising gas exports. Although Russia remains Uzbekistan's largest trading partner, Uzbekistan imports from Russia are smaller than those from China and Korea combined. Turkey, Italy, France and the USA each did more trade with Azerbaijan in 2011 than Russia did. (Table A1, in Appendix 2, shows trade volumes.)

The remainder of this section comprises (i) economic indicators, presented in Table 5, (ii) an overview of the economic strategies devised, and of social and political factors at work, in the four countries, and (iii) some points of comparison and reference to the "resource curse" and other frameworks used to interpret the policies of hydrocarbons-exporting countries.

\footnotetext{
${ }^{4}$ On some political aspects of this process, see Nixey (2012)
} 
Table 5: Caspian and Central Asian Gas Exporters: economic indicators

\begin{tabular}{|c|c|c|c|c|c|c|c|c|}
\hline & 2005 & 2006 & 2007 & 2008 & 2009 & 2010 & $\begin{array}{r}2011 \\
\text { (proj.) }\end{array}$ & $\begin{array}{r}2012 \\
\text { (proj.) }\end{array}$ \\
\hline \multicolumn{9}{|l|}{ Azerbaijan } \\
\hline GDP growth, $\%$ & 24.3 & 34.5 & 25 & 10.8 & 9.3 & 5 & 0.2 & 7.1 \\
\hline GDP per capita (US dollars) & 1,577 & 2,498 & 3,730 & 5,508 & 5,119 & $\mathrm{n} / \mathrm{a}$ & $\mathrm{n} / \mathrm{a}$ & $\mathrm{n} / \mathrm{a}$ \\
\hline Population, millions & 8.4 & 8.4 & 8.4 & 8.4 & 8.4 & $\mathrm{n} / \mathrm{a}$ & $\mathrm{n} / \mathrm{a}$ & $\mathrm{n} / \mathrm{a}$ \\
\hline Oil rents as \% of GDP & 56.1 & 61.9 & 55.9 & 56.2 & 39.6 & 42.6 & $n / a$ & $n / a$ \\
\hline Natural gas rents as \% of GDP & 9.4 & 6.7 & 6.9 & 11.1 & 4.9 & 3.9 & $n / a$ & $n / a$ \\
\hline Export of goods and services, \$bn & 8.3 & 14 & 22.5 & 32.1 & 22.8 & 28.5 & 35.4 & 37.5 \\
\hline Value of hydrocarbons exports, $\$$ bn & 6.9 & 12.1 & 20.2 & 29.1 & 20.0 & 25.1 & 32.9 & 30.5 \\
\hline Hydrocarbons as \% of total exports & 82.9 & 86.2 & 89.7 & 90.8 & 87.6 & 88.1 & 92.9 & 81.3 \\
\hline \multicolumn{9}{|l|}{ Kazakhstan } \\
\hline GDP growth, \% & 9.7 & 10.7 & 8.9 & 3.2 & 1.2 & 7.3 & 6.5 & 5.6 \\
\hline GDP per capita (US d & 3,786 & 5,261 & 6,638 & 8,716 & 6,922 & $\mathrm{n} / \mathrm{a}$ & $\mathrm{n} / \mathrm{a}$ & $\mathrm{n} / \mathrm{a}$ \\
\hline Population, millions & 15.1 & 15.4 & 15.5 & 15.6 & 15.6 & $\mathrm{n} / \mathrm{a}$ & $\mathrm{n} / \mathrm{a}$ & $\mathrm{n} / \mathrm{a}$ \\
\hline Oil rents as \% of GDP & 31.0 & 28.3 & 24.5 & 28.1 & 20.9 & 22.4 & $n / a$ & $n / c$ \\
\hline Natural gas rents as \% of GDP & 10.5 & 7.5 & 6.5 & 8.4 & 4.7 & 2.7 & $n / a$ & $n / a$ \\
\hline Export of goods and services, \$bn & 30.5 & 41.6 & 51.9 & 76.4 & 48.2 & 65.1 & 85.9 & 87.6 \\
\hline Value of hydr & 17.4 & 23.6 & 28.1 & 43.5 & 26.2 & 37.0 & 55.2 & 57.5 \\
\hline Hydrocarbons as \% of total exports & 57 & 56.7 & 54.1 & 56.9 & 54.3 & 56.8 & 64.2 & 65.6 \\
\hline \multicolumn{9}{|l|}{ Turkmenistan } \\
\hline GDP growth, $\%$ & 9 & 11 & 11.1 & 14.7 & 6.1 & 9.2 & 9.9 & 7.2 \\
\hline GDP per capita (US dollars) & 1,283 & 1,565 & 1,961 & 2,916 & 2,843 & $\mathrm{n} / \mathrm{a}$ & $\mathrm{n} / \mathrm{a}$ & $\mathrm{n} /$ \\
\hline Population, millions & 6.5 & 6.5 & 6.5 & 6.5 & 6.5 & $\mathrm{n} / \mathrm{a}$ & $\mathrm{n} / \mathrm{a}$ & $\mathrm{n} / \mathrm{a}$ \\
\hline Oil rents as \% of GDP & 37.5 & 33.0 & 33.5 & 37.5 & 17.1 & 19.7 & $n / a$ & $n / c$ \\
\hline Natural gas rents as \% of GDP & 169.0 & 128.2 & 111.7 & 126.6 & 24.0 & 24.2 & $n / a$ & $n / a$ \\
\hline Export of goods and services, \$bn & 5.3 & 7.5 & 9.5 & 12.3 & 9.5 & 10.3 & 14.9 & 15.8 \\
\hline Value of hydrocarbons exports, \$ bn & 4.2 & 6.2 & 8.1 & 11.0 & 8.4 & 8.6 & 15.8 & 16.7 \\
\hline Hydrocarbons as \% of total exports & 79.2 & 83.1 & 85 & 89.4 & 88.6 & 83.5 & 106 & 105.7 \\
\hline
\end{tabular}

\section{Uzbekistan}

\begin{tabular}{|l|r|r|r|r|r|r|r|r|}
\hline GDP growth, \% & 7 & 7.5 & 9.5 & 9 & 8.1 & 8.5 & 7.1 & 7 \\
\hline GDP per capita (US dollars) & 568 & 631 & 815 & 1,007 & 1,070 & $\mathrm{n} / \mathrm{a}$ & $\mathrm{n} / \mathrm{a}$ & $\mathrm{n} / \mathrm{a}$ \\
\hline Population, millions & 26.2 & 27.0 & 27.4 & 27.7 & 28.3 & $\mathrm{n} / \mathrm{a}$ & $\mathrm{n} / \mathrm{a}$ & $\mathrm{n} / \mathrm{a}$ \\
\hline Oil rents as \% of GDP & 9.6 & 8.3 & 6.4 & 6.8 & 2.8 & 3.3 & $n / a$ & $n / a$ \\
\hline Natural gas rents as \% of GDP & 91.4 & 76.5 & 59.8 & 73.8 & 25.4 & 18.1 & $n / a$ & $n / a$ \\
\hline Export of goods and services, \$bn & 5.4 & 6.3 & 8.9 & 12.2 & 11.5 & 12.2 & 15.8 & 17.2 \\
\hline Value of hydrocarbons exports, \$ bn & $\mathrm{n} / \mathrm{a}$ & $\mathrm{n} / \mathrm{a}$ & $\mathrm{n} / \mathrm{a}$ & $\mathrm{n} / \mathrm{a}$ & $\mathrm{n} / \mathrm{a}$ & $\mathrm{n} / \mathrm{a}$ & $\mathrm{n} / \mathrm{a}$ & $\mathrm{n} / \mathrm{a}$ \\
\hline Hydrocarbons as \% of total exports & $\mathrm{n} / \mathrm{a}$ & $\mathrm{n} / \mathrm{a}$ & $\mathrm{n} / \mathrm{a}$ & $\mathrm{n} / \mathrm{a}$ & $\mathrm{n} / \mathrm{a}$ & $\mathrm{n} / \mathrm{a}$ & $\mathrm{n} / \mathrm{a}$ & $\mathrm{n} / \mathrm{a}$ \\
\hline
\end{tabular}

Sources: IMF Regional Economic Outlook (GDP growth, exports); IMF World Economic Outlook database (hydrocarbons exports); EBRD selected economic indicators (GDP per capita, population); World Bank data (oil and gas rents) 


\section{Kazakhstan}

Kazakhstan, the largest energy producer and exporter in the Central Asian and Caspian region, has generally pursued economic policies based on oil-led economic development. In the initial post-Soviet period, much effort had to be focused on loosening Kazakhstan's ties with Russia, not only economically but even in terms of physical infrastructure. For example the electricity grid, poorly suited to an independent Kazakhstan, began to be reconstructed. Even now many infrastructural links persist - such as, in the gas sector, the processing of gas from one of Kazakhstan's largest fields, Karachaganak, at Orenburg over the Russian border. In the 1990s, Kazakhstan's political and economic elite pushed more vigorously than others in Central Asia for privatisation and other pro-market economic reforms - and some economists have argued that the imperative of achieving greater economic independence from Russia pushed them further in that direction. ${ }^{5}$ The privatisation of the oil industry was characterised by a series of large deals with international oil companies (IOCs), including the production-sharing agreement signed in 1993 with Chevron and others for the Tengiz field, the PSAs signed in 1997 covering the Kashagan and Karachaganak projects, and the sale of stakes in large oil companies to Indonesian, Chinese, American and other companies. This struck a contrast with the Russian privatisations of the same period that mainly benefited Russian-owned companies. Kazakhstan also took determined steps to integrate into the world economy and financial system: liberalisation of prices (for food, consumer goods, industrial goods, etc) was largely complete by the end of 1994; its currency was made convertible in 1996; it took steps to establish private banks and a stock exchange. ${ }^{6}$

In the 2000s, on the back of rising international oil prices, Kazakh oil output grew substantially: having wavered between 20 and 27 million tonnes/year since the late Soviet period (1985-1998), oil production rose steadily from 30.8 million tonnes in 1999 to 78 million tonnes in 2009. ${ }^{7}$ Although Kazakhstan's economy is more diversified than e.g. Azerbaijan's or Turkmenistan's - it mines and exports coal, metals and uranium as well as oil and gas, and also has some industrial capacity built up in Soviet times - oil remains its most important industry and most valuable export. The oil boom resulted, as it did in Russia, in rapid economic expansion and rising average living standards. It also formed the background, first, to the government's decision to increase the state's role in the oil industry, in the first place by greater involvement by Kazmunaigaz, the national oil and gas company established in its current form in 2002, and second, to a series of increasingly serious disputes between the government and IOCs, both western and Chinese, over the terms of access to upstream assets. This came to a climax with the renegotiation in 2007 of the PSA for the Kashagan project, where costs had risen sharply in the course of the oil boom. Some researchers have interpreted this shift in policy in the context of "resource nationalism", i.e. the perception by producer country governments that hydrocarbons resources are a means to nation-building. 8 In any case, in the last few years, the government has brought substantial assets into Kazmunaigaz, including shares in the Tengiz and Kashagan projects, and floated shares in its exploration and production subsidiary on the international stock exchanges.

\footnotetext{
${ }^{5}$ This argument is made in Blackmon (2011), pages 7, 18 and 95-97. On the relationship between Russia and Kazakhstan see also Sorbello (2011).

${ }^{6}$ See e.g. Blackmon, op. cit.; Luong and Weinthal (2010), pp. 261-265; and Ostrowski (2010), pp. 32-72.

${ }^{7}$ BP Statistical Review of World Energy, various issues.

${ }^{8}$ Recent examples are Kalyuzhnova and Nygaard (2008), pp. 1829-1842; Cutler (2012); and Sarsenbayev (2011) , pp. 369-379.
} 
Kazakhstan, which has a population of 17 million, has higher GDP per head, and higher average living standards, than other Central Asian states. But severe inequalities in living standards persist; some researchers have argued that there has been a failure in the manner in which oil revenues have been redistributed. ${ }^{9}$ The gap between richer and poorer regions of the country widened sharply during the 2000s, with Mangistau, one of the principal oil producing regions with $32.4 \%$ of the population, registering the highest poverty level in 2008 . Accumulating social unrest gave rise in 2011 to a lengthy strike by oil workers demanding changes to pay and working conditions, which Kazmunaigaz E\&P reported as the principal cause of a fall in output in that year; this dispute culminated in December 2011 in violent clashes with security forces involving at least 17 fatalities. In the IMF's judgement the strikes signalled "underlying discontent", and against this backdrop, the government has announced increased social spending and investment projects in non-oil sectors, including employment programmes. ${ }^{10}$ These social tensions need to be borne in mind with respect to the government's gas sector policy. The priority it accords to gasification, its projection of more than doubling domestic consumption by 2020, and its requirement that associated gas be utilised for local supply and the necessary infrastructure constructed, is part of a wider social policy aimed at addressing the causes of discontent.

\section{Azerbaijan}

Azerbaijan emerged from the Soviet Union with great potential as an oil-producing nation but also with a damaging legacy from the break-up of the Union. This consisted of its diplomatic and military conflicts with Armenia over the status of Nagorno-Karabakh (198894) and the unresolved status of Nagorno-Karabakh. Azerbaijan's geographical position west of the Caspian meant that it was seen from the moment of its independence as a potential exporter of oil and gas westward to Turkey and European destinations. This was a key consideration not only for the new Azeri governing class, but also for the USA and the large European oil consuming nations, who attached their hopes of gaining access to Caspian resources in the first place to Azerbaijan. In 1994, shortly after signing a ceasefire with Armenia, Azerbaijan signed the PSA with the AIOC consortium to develop the Azeri-ChiragGunashli field (ACG). This set the pattern for the development of Azerbaijan's hydrocarbons resources: it would be carried out by its national state-owned oil and gas company, Socar, in partnership with IOCs. This partnership, in different corporate forms, undertook the construction of the Baku-Tbilisi-Ceyhan pipeline that brought ACG oil to the Mediterranean and the South Caucasus pipeline alongside it through which Azeri gas is exported to Turkey, and is now developing the Shah Deniz gas field.

Azerbaijan's economy is even more oil-dependent than Kazakhstan's; its non-hydrocarbons sector is even less significant than Kazakhstan's. During the oil boom of the 2000s, the oil and gas sector's share in exports rose from around $85 \%$ to around $90 \%$ (as Table 5 above shows), and Azerbaijan experienced double-digit growth. It weathered the recession well due to high oil prices; the decline in oil output in 2010 (partly related to extensive maintenance works) was the main factor in reducing the pace of growth. ${ }^{11}$ In Azerbaijan, as in Kazakhstan, oil revenues have been unevenly distributed; some areas of the country retained high poverty rates through the oil boom, a problem exacerbated by the large number of internally displaced

\footnotetext{
${ }^{9}$ Najman, Pomfret, Raballand and Sourdin (2008), pp. 111-131

${ }^{10}$ UNDP Kazakhstan, Human Development Report 2009, pp. 103-106; Kazmunaigaz E\&P Annual Report 2011, pp. 4-5; IMF 2012 Article IV Report: Republic of Kazakhstan, p. 4.

${ }^{11}$ Luecke and Trofimenko (2008) pp. 132-175; Kalyuzhnova (2008), pp. 11-12 and 37-39; Luong and Weinthal (2010) pp. 219-258. On the economy in 2010, EBRD Transition Report 2010, pp. 114-115.
} 
refugees (a result of the conflict with Armenia). Researchers who studied this issue drew the "preliminary" conclusion that some revenue redistribution had been accomplished, i.e. that the government had used part of its rents to mitigate the impact of the war with Armenia and of economic problems on vulnerable sections of the population - but that many problems remained. ${ }^{12}$ It is also clear that the unresolved conflict with Armenia remains a key factor in Azerbaijan - not only in respect of the internal refugees and other effects on the economy, but also because, in political circles, resolution of the conflict remains high on the agenda and some see the strategic advantages that result from Azerbaijan's position as a hydrocarbons exporter as a means to resolve the dispute. ${ }^{13}$

A big challenge for the Azeri economy in the coming years is the fall in oil export revenue, and the impact on economic growth, which will result from the decline of the ACG field from about 2015. The IEA recently projected that total Azeri production will reach a peak of about 65 million tonnes/year in 2014-15, and then decline steadily to under 55 million tonnes/year by 2030 , and more rapidly thereafter. Earlier estimates by the World Bank forecast a higher peak, 70 million tonnes/year in 2009-10, and a more rapid decline, to 20 million tonnes/year by 2024 . Actual production statistics suggest that the peak may be still lower than the IEA's estimates: output of 44.7 million tonnes (2008), 50.6 million tonnes (2009), 50.8 million tonnes (2010) and 45.6 million tonnes (2011) has been registered. ${ }^{14}$ The government has indicated that a planned increase in gas production - in the first place from the Shah Deniz field, but then from other fields that are currently undeveloped - is central to its strategy. This focus on gas may be the reason that the Azeri government has become increasingly pro-active in influencing the development of export routes and construction of westward pipeline infrastructure, as discussed in section 5.5 below. It is argued below in section 3.4 that the government's stance may also support the development of the post-Shah Deniz fields. It is unlikely, however, that the export revenues from Azerbaijan's gas resources could fully replace those derived from oil.

\section{Turkmenistan}

Turkmenistan's economy became heavily reliant on gas exports in the Soviet period, and has continued to be ever since. Its only other significant exports are oil products from the Turkmenbashi refinery and cotton; its agricultural sector and its small textile industry mainly supply the domestic market. In Soviet times, up to $90 \mathrm{bcm} / \mathrm{year}$ of Turkmen gas was added to the gas balance of Russia and other Soviet republics; it was assumed in accounting terms that a proportion of this was exported to western Europe, in exchange for which Turkmenistan received a quota of hard currency. This system continued in the first years after independence, and in 1990-93, the only years for which information is available, this hard currency quota equated to $15-25 \%$ of Turkmenistan's total exports. In the mid 1990s, the collapse of the Russian and Ukrainian economies disrupted this arrangement; cash payments for gas dried up, and barter payments were introduced. By this time intra-Soviet payment methods had been replaced by sales contracts between Turkmen entities and industrial and energy sector customers, mostly in Ukraine - but barter continued to account for a substantial part of Turkmenistan's gas export revenues until 2005. ${ }^{15}$ Turkmenistan was constrained by dependence on pipelines running through Kazakhstan and Russia. From the early 1990s, diversification of gas exports was declared an important aim, but with the corollary that the

\footnotetext{
${ }^{12}$ Luecke and Trofimenko (2008) p. 152

${ }^{13}$ Ibragimov (2012) pp. 39-52. See also Kjaernet (2009), pp. 2-5

${ }^{14}$ IEA World Energy Outlook 2010, p. 504; World Bank (2005); BP Statistical Review of World Energy, 2012.

${ }^{15}$ Stern (2005), p. 72; Bagratian and Gurgen (1997), pp. 4-5; Dodsworth, Mathie and Shiells (2002), p. 13.
} 
volumes would be sold at the border with buyers assuming all transport and other associated risks - a function of Turkmenistan's small size and lack of experience of statehood. The opening of the first pipeline to Iran in 1997 was the first success of the diversification policy, while the cessation of exports to Russia in the same year, as a result of a dispute over prices, underlined the difficulties caused by dependence on Russia.

The economic boom of the mid and late 2000s helped Turkmenistan in three ways. First, gas prices in Europe (which were linked to those of oil) rose steeply, and Russia, conscious of the persistent efforts by China and Europe to source gas from Central Asia, agreed to pass through the benefit of these prices to Turkmenistan and the other Central Asian exporters. ${ }^{16}$ Second, gas demand in Russia rose sharply, supporting Russia's own demand for Central Asian imports. Third, China, which elevated the sourcing of energy supplies to a strategic priority as its economic growth accelerated, agreed to build a pipeline from Turkmenistan to its western border and committed to substantial gas purchases into the future. The replacement of Russia by China as the main export destination for Turkmen gas is one of the key developments dealt with in this paper, particularly in sections 5.1-5.3 below.

Post-Soviet Turkmenistan has made few pro-market economic reforms. Not only the oil and gas sector but most other economic activity, including the financial sector, remains in state hands; many prices are controlled; and water, gas and electricity are provided free to the population. Politically, an autocratic system of presidential rule has been established, with no legislature to speak of, no meaningful elections, and no evidence of freedom of speech or assembly. ${ }^{17}$ The dispute with Russia in 1997-98 led some observers to believe that a combination of low gas export prices and friction with Russia might lead Turkmenistan's model of political and economic development into crisis. But the dispute was resolved, and from the mid 2000s, gas export revenues were sufficient to fund substantial increases in public sector wages and other social benefits; numerous prestige projects; and a considerable expansion of Turkmenistan's sovereign wealth funds.

In 2009, Turkmenistan experienced a second major dispute with Russia and a reduction of Russian purchases - but, firstly, the start-up of exports to China was by then only months away, and, secondly, export prices were so much higher than in 1997-98, and Turkmenistan's finances were so much stronger, that the two disputes are not really comparable. In this connection it is relevant to correct two misconceptions that became widespread among western observers: (i) that Turkmenistan would experience a debt crisis as a result of the dispute with Russia in 2009; and (ii) that over the longer term the Chinese export trade would be insufficient to finance Turkmenistan's needs, and that Turkmenistan would be driven by economic necessity to raise gas output e.g. to $230 \mathrm{bcm} /$ year (which is the government's target for 2030), and to make significant changes in its upstream policy (e.g. to abandon the strict limits placed on upstream activity by IOCs) and/or its export policy (e.g. by abandoning its requirement that prospective customers finance and build pipelines, and by becoming active in that area itself).

In fact, with regard to (i), the limited information available suggests that while Turkmenistan probably drew on its offshore sovereign wealth funds in 2009 to balance its budget, and was unable to contribute to them in 2010, it has weathered the storm of its 2009 dispute with Russia. (Turkmenistan's fiscal position, the contribution of gas and other export revenues to it, and the statistics published by the IMF and other bodies, are covered in Appendix 3).

\footnotetext{
${ }^{16}$ Details in Henderson, Pirani and Yafimava (2012).

${ }^{17}$ An overview of the economy is: Pomfret (2006), pp. 46-73; see also Peyrouse (2012)
} 
As for (ii), the outlines of an answer to this question are available to all observers. They are: (a) Turkmenistan's economic model relies on it being able to finance almost all state spending from gas revenues. It was apparently able to do this up until the mid 2000s without taking on any substantial debt, and its debt-to-GDP ratio remains negligible.

(b) From the mid 2000s, it was evident to the casual observer - who could see that many hundreds of millions of dollars were being spent on prestige building projects (financed offbudget), and that Turkmenistan was putting money into offshore sovereign wealth funds that the export revenues exceeded Turkmenistan's basic spending requirements.

(c) While it could take two or three more years from the time of writing for Turkmenistan's exports to reach the level by volume that they were at in the mid $2000 \mathrm{~s}$, each cubic metre of gas is being sold for at least five times the price that was paid in the mid 2000s.

(d) While Turkmenistan has taken $\$ 9$ billion of loans from China to finance the development of the South Yolotan gas field, as part of the two countries' strategic partnership, this debt burden is insubstantial in comparison to that of most other countries, and insubstantial in comparison to even the most conservative estimates of future revenues from gas exports from South Yolotan.

The argument put here is that, even if Turkmenistan's budget spending rises - as usually happens in hydrocarbons-exporting countries, even with small populations, at times of high prices - tension may well be placed on the state's finances, but there is no evidence at this point that that tension would produce a crisis. This argument would have to be reassessed in the case of any major change in Turkmenistan's relationship with China that had a substantial impact on export revenues, e.g. a sudden and unexpected reduction of purchases or a Chinese demand for substantial renegotiation of gas prices. At present, no such change is on the horizon - although over the course of this decade, a renegotiation of prices and/or price formulae is possible. (See section 5.3.) Note also that this argument does not imply that Turkmenistan's political-economic model is assured of avoiding crises brought on by other causes. The way that the social crisis in the Middle East and North Africa has shaken not only countries with large, restive populations, but also those with small populations and little history of unrest, suggests that no states are immune from such developments.

The final point is that it is difficult to see, except in the case of very drastic changes in its relationship with China, why Turkmenistan would either try to increase its gas output much above 100-150 bcm/year, or make rapid changes in its policies on upstream access and gas exports. Such a scenario is difficult to reconcile with its record of statecraft over the last two decades. Turkmenistan emerged as one of the smallest post-Soviet republics by population. Its government, in which the president has the overwhelming role in making decisions, has always proceeded cautiously in its international relationships, of which none of its leading personnel had any previous experience; its "multi vector" foreign policy is designed to ensure peaceful cooperation in the relevant fields with its larger partners. Moreover, Turkmenistan has a limited pool of officials able to participate in government, energy sector management, etc. One of the problems caused by its political-economic model is that it appears to have eroded the cadre of officials further and constrained relevant forms of education and training. Autarchic economic policies and minimal social, cultural and political interchange with other countries have taken their toll. The collective capacity of Turkmenistan's elite to conduct 
relationships with business and trading partners is therefore limited. ${ }^{18}$ None of this means that Turkmenistan will never change the outlines of the strategy it has devised for the hydrocarbons upstream and export. But it does mean that, since that strategy has served the government's requirements adequately for the past two decades, it has every incentive to remain extremely cautious about change.

\section{Uzbekistan}

Uzbekistan, unlike the other three countries covered here, is not a major exporter of energy. The economy is heavily dependent on cotton; Uzbekistan is one of the largest cotton producers and exporters in the world. Gold, and to a lesser extent copper, uranium and some minor metals, are also significant exports. Uzbekistan's considerable energy resources, of which gas is the most significant, are used principally to fuel the domestic economy. This economic structure is inherited from the Soviet Union; in the late Soviet period, Uzbekistan was a net energy importer, importing both oil and hydroelectricity from other Soviet republics, while its main contribution to the Soviet economy was cotton. ${ }^{19}$

After the break-up of the USSR, Uzbekistan was far slower than e.g. Kazakhstan to adopt economic reforms. From 1994 Uzbekistan, following advice from the IMF, relaxed foreign exchange controls, reduced price controls and committed itself to currency convertibility. But in 1996 it abruptly reversed its policy, re-imposing exchange controls; a limited form of currency convertibility was introduced in 2003 but exchange controls and a multiple exchange rate remain. Privatisation and financial sector reform have been limited. ${ }^{20}$ Some researchers argue that Uzbekistan lacks a strong local elite that would benefit from privatisation and therefore support economic reform. ${ }^{21}$ Whether or not that is the case, it is indisputable that by the 2000 s the government had found its way to an autarchic economic policy in which intensive industrial development and import substitution policies played a prominent role.

Uzbekistan, which has a larger population than the rest of Central Asia put together, has experienced significant social tensions in recent years. ${ }^{22}$ Rioting and protests have not recurred on the scale of the 2004-05 unrest, which culminated in the Andizhan events in which the security forces killed 179 demonstrators (according to official statistics) - but most observers believe that the underlying tension that sparked these events remains. Poverty and unemployment rates are high, and migration to Russia and elsewhere to find work is high. The use of gas as a cheap input for the local economy, to fuel energy-intensive schemes to encourage small industry, and as a subsidy for the population (described below in section 4.1), needs to be considered in this context.

\footnotetext{
${ }^{18}$ This does not mean, however, a lack of interest in international cooperation. A good example from the hydrocarbons sector is the new series of publications by the Institute of Oil and Gas, the research division of Turkmengaz, clearly directed at attracting international interest from geologists and other specialists in research issues in Turkmenistan. Among the publications so far are: Tashliev (2010) and Bairamova et al. (eds.) (2011)..

${ }^{19}$ Pomfret (2006) pp. 25-30 and 143-153; Luong and Weinthal (2010), p. 80.

${ }^{20}$ Pomfret, ibid., pp. 30-37

${ }^{21}$ For example Blackmon (2011) pp. 29-34 and 36-41.

${ }^{22}$ For a discussion of the implications, see De Cordier (2012).
} 
There is a considerable literature on the economies of the Central Asian and Caspian states and the paths of development they may follow. Some researchers have argued that, in order to sustain economic growth, a common challenge for Kazakhstan, Azerbaijan and Turkmenistan is to diversify away from the hydrocarbons sector, both by retaining oil and gas revenues in transparently-managed sovereign wealth funds and by establishing frameworks for competitive growth in non-hydrocarbons sectors. ${ }^{23}$ The success of such policies in the region has so far been limited. The governments of Kazakhstan and Azerbaijan have stated their intention of promoting non-oil economic sectors (e.g. manufacturing, consumer goods production, etc), but such policies have yet to make a substantial impact on either economy. In Turkmenistan, economic policy remains focused on gas-driven development. In all four countries, there are examples of government-backed initiatives designed to promote energyintensive industries (e.g. petrochemicals), but the results of these have been limited, and the long-term impact is still unclear.

Some researchers argue that hydrocarbons exporters such as Turkmenistan, Azerbaijan and Kazakhstan suffer from the "resource curse", i.e. that the presence of hydrocarbons resources, and the economies' heavy dependence on the revenues they generate, confounds economic and political development. A recent polemic against some of the "resource curse" literature, by Pauline Jones Luong and Erika Weinthal, presents detailed studies of former Soviet economies, including the four covered in this paper, and concludes that the "resource curse" concept has "impeded our understanding of the relationship between mineral wealth and institutions", by taking too little account of changes in historical circumstances, and wrongly ignoring other factors such as the ownership structure of the hydrocarbons-producing companies. $^{24}$ This paper does not seek to make a contribution to this debate. But the author favours approaches that consider the economies of hydrocarbons-producing countries in an all-sided manner - rather than some of the too narrowly-focused uses of such interpretive concepts as the "resource curse" - and hopes that the material presented here on the gas sector might be of use in doing so.

Points that emerge from research of the gas sector, that might be of use in forming a clearer understanding of the drivers of economic development and of economic policy, include:

(i) a distinction between Uzbekistan, which exports cotton and gold but uses its main hydrocarbons resource, gas, to fuel its domestic economy, underpinning economic policies of autarchy and import substitution, and the other three states, for whom hydrocarbons exports are the main driver of economic development; and

(ii) significant differences in gas policies between the three other countries. In Turkmenistan, where gas rather than oil is the most significant hydrocarbons resource, production will be increased to serve the Chinese market but, for now, other export routes will not be opened up and resources to supply them will not be developed. Turkmenistan has discovered gas resources sufficient to underpin many decades of production at two, three or more times the

\footnotetext{
${ }^{23}$ This argument is made in Kalyuzhnova (2008), pp. 44-65, 206-213 and 220-222

${ }^{24}$ Luong and Weinthal (2010), p. 322. An example of the "resource curse" approach is Sabonis-Helf (2004), pp. 159-185. Pomfret (2006) p 167 concludes from his discussion of the applicability of the "resource curse" argument to Central Asia that the long-run relationship between resource abundance and economic performance is hard to assess; that resource booms create potential for investment to promote long-run economic growth but that global evidence indicates that resource abundance can be a curse; and that "a more subtle interpretation relates the characteristics of the specific resource to institutional change".
} 
current level. This paper argues that output e.g. at twice the current level (i.e. $110 \mathrm{bcm} /$ year) is probably sufficient to meet the country's economic and fiscal needs, no matter how generously interpreted, and that the political elite, conscious of its own limited capacity for managing large-scale production and commercial relationships, has no real incentive to develop production much further than that. In Kazakhstan, the government's priority is and will remain to produce oil for export, in partnership with IOCs; gas production will be mainly for domestic consumption, which is being increased, with an emphasis - stemming primarily from the government's social policy - on upgrading networks built in Soviet times and gasifying new areas. In Azerbaijan, the emphasis is on raising output of gas for export westwards; as oil output declines from 2015, the government hopes that part of the lost revenue will be compensated by gas exports, and will therefore probably do its best to stimulate the development not only of Shah Deniz II but of other new fields. 


\section{Reserves and production}

Table 6 shows the proven gas reserves in the Central Asian and Caspian producing countries, with the Russian Federation included for comparison, as reported by BP ${ }^{25}$. The most important change in recent years is the rapid increase in Turkmenistan's volume of proven reserves, due to the progress of geological surveys of the South Yolotan (Galkynysh) field, now confirmed as the world's second largest behind the South Pars field shared between Iran and Qatar. This makes Turkmenistan's reserves the fourth-largest in the world, behind Russia, Iran and Qatar, with nearly three times the reserves of the USA, the fifth-placed country by reserves. The other recognised source of reserves data available to this author, the Cedigaz compilation Natural Gas in the World, also acknowledges the South Yolotan field as the world's second largest, and Turkmenistan's reserves as the world's fourth largest, but has restated Turkmenistan's reserves as $10 \mathrm{tcm}$, as against BP's estimate of $24.3 \mathrm{tcm} .^{26}$ The difference is in the assessment of the field's development potential (see section 3.1 below, in the sub-section "South Yolotan (Galkynysh)").

The other interesting point brought out by Table 6 is Uzbekistan's relatively low level of proven reserves, which have fallen below 30 years' worth of production, and hardly increased for the last five years, indicating a lack of successful exploration activity.

Table 6: Reserves and Reserves-Production Ratios

\begin{tabular}{|c|c|c|c|c|c|c|c|}
\hline \multicolumn{8}{|c|}{ Proved reserves of natural gas $(\mathrm{Tcm}) *$} \\
\hline & & 1997 & 2007 & 2008 & 2009 & 2010 & 2011 \\
\hline \multicolumn{2}{|l|}{ Turkmenistan } & 2.6 & 2.6 & 8.1 & 8.0 & 13.4 & 24.3 \\
\hline \multicolumn{2}{|l|}{ Uzbekistan } & 1.6 & 1.7 & 1.7 & 1.6 & 1.6 & 1.6 \\
\hline \multicolumn{2}{|l|}{ Kazakhstan } & 1.8 & 1.9 & 1.9 & 1.9 & 1.9 & 1.9 \\
\hline \multicolumn{2}{|l|}{ Azerbaijan } & 0.8 & 1.2 & 1.3 & 1.3 & 1.3 & 1.3 \\
\hline \multicolumn{2}{|l|}{ Russian Federation } & 43.8 & 43.3 & 43.3 & 44.4 & 44.4 & 44.6 \\
\hline \multicolumn{8}{|c|}{ Reserves/production ratio** and production (bcm) } \\
\hline \multirow{3}{*}{ Turkmenistan } & & 1997 & 2007 & 2008 & 2009 & 2010 & 2011 \\
\hline & $\mathrm{R} / \mathrm{P}$ ratio & 167.6 & 39.5 & 122.7 & 221.2 & 315.7 & 408.4 \\
\hline & Production & 15.7 & 65.4 & 66.1 & 36.4 & 42.4 & 59.5 \\
\hline \multirow[t]{2}{*}{ Uzbekistan } & $\mathrm{R} / \mathrm{P}$ ratio & 34.2 & 28.6 & 27.1 & 27.0 & 26.9 & 28.1 \\
\hline & Production & 46.4 & 59.1 & 62.2 & 60.0 & 59.6 & 57.0 \\
\hline \multirow[t]{2}{*}{ Kazakhstan } & $\mathrm{R} / \mathrm{P}$ ratio & 296.6 & 112.9 & 100.6 & 105.7 & 107.0 & 97.6 \\
\hline & Production & 6.1 & 16.7 & 18.7 & 17.8 & 17.6 & 19.3 \\
\hline \multirow[t]{2}{*}{ Azerbaijan } & $\mathrm{R} / \mathrm{P}$ ratio & 27.6 & 126.5 & 88.7 & 85.6 & 84.2 & 85.8 \\
\hline & Production & 5.4 & 9.8 & 14.8 & 14.8 & 15.1 & 14.8 \\
\hline \multirow[t]{2}{*}{ Russian Federation } & $\mathrm{R} / \mathrm{P}$ ratio & 85.1 & 73.2 & 72.0 & 84.1 & 75.4 & 73.5 \\
\hline & Production & 515.2 & 592.0 & 601.7 & 527.7 & 588.9 & 607.0 \\
\hline \multicolumn{8}{|c|}{$\begin{array}{l}\text { * defined as those quantities that geological and engineering information indicates with } \\
\text { reasonable certainty can be recovered in the future from known reservoirs under existing } \\
\text { economic and operation conditions }\end{array}$} \\
\hline
\end{tabular}

Source: BP Statistical Review of World Energy, 2012

\footnotetext{
${ }^{25}$ BP Statistical Review of World Energy - June 2012

${ }^{26}$ Cedigaz, Natural Gas in the World: 2012 Edition, pp. 10 and 19-20.
} 
Table 7: Leading Gas Reserves Holders

\begin{tabular}{|c|c|c|c|c|c|}
\hline \multicolumn{6}{|c|}{ Proved reserves, trillion cubic metres, at year-end } \\
\hline & & 2001 & 2010 & \multicolumn{2}{|r|}{2011} \\
\hline & & $\mathrm{tcm}$ & $\mathrm{tcm}$ & tcm & $\begin{array}{r}\text { share of } \\
\text { total }\end{array}$ \\
\hline 1 & Russian Federation & 42.4 & 44.4 & 44.6 & $21.4 \%$ \\
\hline 2 & Iran & 26.1 & 33.1 & 33.1 & $15.9 \%$ \\
\hline 3 & Qatar & 25.8 & 25.0 & 25.0 & $12.0 \%$ \\
\hline 4 & Turkmenistan & 2.6 & 13.4 & 24.3 & $11.7 \%$ \\
\hline 5 & US & 5.2 & 8.2 & 8.5 & $4.1 \%$ \\
\hline 6 & Saudi Arabia & 6.5 & 8.0 & 8.2 & $3.9 \%$ \\
\hline \multicolumn{2}{|c|}{ Total World } & 168.5 & 196.1 & 208.4 & $100.0 \%$ \\
\hline
\end{tabular}

Source: BP Statistical Review of World Energy, 2012

Overall, Table 7 shows that Turkmenistan's reserves are sufficient for it to develop substantially its role as a major gas producer and exporter, and that the constraints on such development are entirely related to its ability to produce, transport and market the gas. Kazakh and Azeri reserves are also ample to allow for production growth, but the situation in Uzbekistan is less straightforward. The remainder of this section covers upstream activities in the four countries. Maps 2-5 show the location of all the most important fields and pipelines.

\subsection{Turkmenistan}

Turkmenistan's currently producing assets are of three types, shown on Map 2:

(i) onshore natural gas fields, mostly developed in the Soviet period, including (a) a relatively small group of fields in the west, mainly operated by the state oil production company Turkmenneft, from which gas may be exported southwards to Iran via the Korpedzhe-Kord Kuy pipeline, and (b) a much larger group of fields in the south east and east, operated by Turkmengaz, that can supply either the Central Asia-Centre pipeline to Russia, the Central Asia-China pipeline, or in the case of the largest field, Dauletabad, the Dauletabad-SarakhsSangbast pipeline to northern Iran;

(ii) the onshore fields on the left bank (i.e. north-eastern side) of the Amu Darya river, bordering on Uzbekistan, in the block licensed to China National Petroleum Corporation (CNPC) under a production sharing agreement, from which gas is fed directly into the Central Asia-China pipeline.

(iii) offshore blocks, some of which are licensed to foreign companies, that produce small quantities of gas along with oil, and can raise production only if and when agreement is reached with the Turkmen authorities and Turkmengaz on the terms of its purchase and export.

This section sets out the historical and political context, and then covers current production and development of South Yolotan and other new fields. 


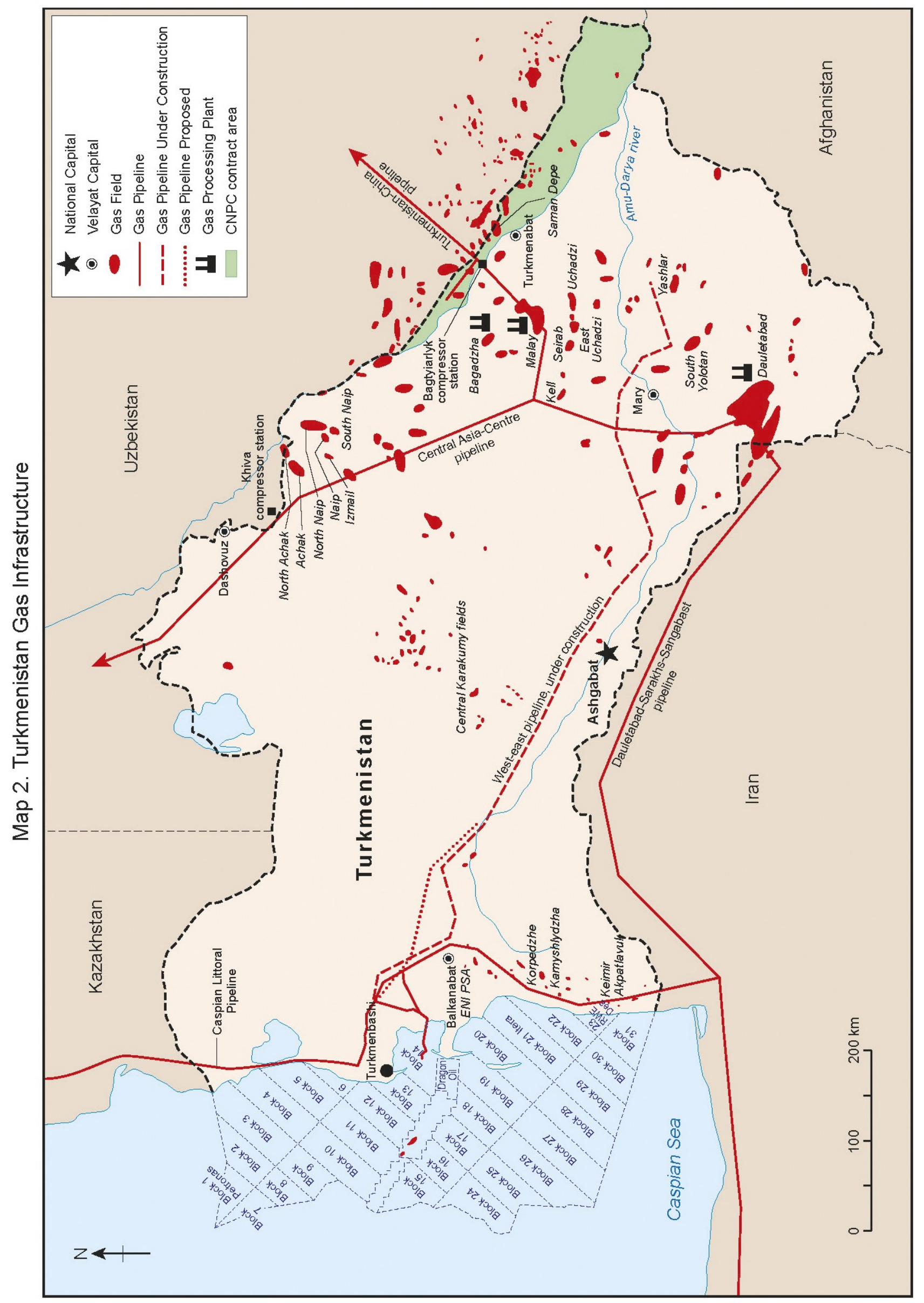




\section{Historical and political context}

The origins of gas production in Turkmenistan in Soviet times, and the disruption of those economic relationships in the 1990s, were covered in section 2 above. In 1997 Turkmenistan took its first step towards export diversification, by starting to sell gas from its western fields to Iran. In the 1990 s and early 2000 s, Turkmenistan also sought to establish a commercial relationship with Ukraine, and sold some gas to Naftogaz Ukrainy and other Ukrainian entities on its border, with a transit fee being paid to Russia - but this came to an end in 2006, when Gazprom signed a contract under which it effectively bought all Turkmenistan's westward-bound gas. ${ }^{27}$ The next, and by far the more important, step towards export diversification came in 2006, when Turkmenistan concluded a framework agreement with China under which it agreed to build the Central Asia-China pipeline and for China to participate in developing the Amu Darya deposits. Construction of the pipeline began in 2007.

In April 2009, Russia sharply cut its purchases from Turkmenistan; in December of that year, shipments to China began. (See Section 5.1). These two events have shaped the development of Turkmenistan's upstream assets since then. Exports to Russia are now expected to stay at their current low level for the foreseeable future, and plans mooted in the early 2000s to build a Caspian Coastal pipeline from western Turkmenistan to Russia have been put on hold with the result that offshore gas being developed by foreign companies is in danger of being stranded. In south-eastern Turkmenistan, by contrast, development is being stimulated by demand from China, and potentially from elsewhere in Central Asia. The new (CAC) pipeline is already accepting gas from Malay and other Turkmengaz fields in the south east, and from the CNPC fields; it will also provide a route to market for gas from South Yolotan.

The government's policy on gas exports has since the mid 1990s been conducted in line with its "multi vector" foreign policy, i.e. of seeking constructive relationships with all its neighbours. It has (i) sought to diversify export routes, and (ii) maintained a requirement that gas be sold on the Turkmen border; the government seeks to minimise its involvement with infrastructure projects beyond its borders and to place all of the export risks - transportation and marketing - with buyers.

Turkmenistan's attitude to foreign investment in upstream oil and gas production, like its stance on exports, must be seen in the context of its economic requirements and its foreign policy. It has been argued above in section 2 that, although Turkmenistan has officially set ambitious targets for raising production - most recently, to $230 \mathrm{bcm} /$ year by 2030 - there is no obvious economic rationale for such a steep increase. Turkmenistan's post-Soviet history suggests that, while its government sees gas production as the foundation stone on which the rest of the economy rests, it intends to proceed cautiously. In particular, while the government has for many years sought the involvement of foreign partners to explore and develop blocks in the Turkmen sector of the Caspian sea, it has always been reluctant to conclude production sharing agreements (PSAs) for onshore fields. The one exception has been the Amu Darya PSA with CNPC (see below), which was agreed on in the context of the strategic Turkmen-Chinese partnership and plans for large-scale gas exports. Turkmenistan's ongoing reluctance to bring IOCs (except those from China) into onshore PSAs is illustrated by the single case of an onshore PSA (for some oil fields in western Turkmenistan), signed in the mid 1990s with a small western company (Burren Energy). In 2007, Burren was taken over by ENI of Italy. The takeover was not cleared with the authorities in advance; this

\footnotetext{
${ }^{27}$ For details on the 1990s, see Pirani (2009), especially pp. 288-297.
} 
resulted in friction between ENI and the government, and largely for that reason, production from the field was halved from $24,000 \mathrm{bpd}$ (2007) to $12,000 \mathrm{bpd}(2010){ }^{28}$

Under the regulatory system set up in 2007-08 - when the State Agency on Management and Use of Hydrocarbon resources was set up to issue licences and contracts, and the Hydrocarbon Law was passed, to provide greater clarity on the ownership of projects foreign investors have only been invited to participate in offshore projects. In 2011, the government announced explicitly that PSAs would not be offered onshore. Consequently, the South Yolotan field is being developed by Turkmengaz as project manager, and with CNPC and other foreign companies working on service contracts. ${ }^{29}$

\section{Production (onshore)}

The mainstay of Turkmen gas production historically is the Dauletabad field in the south-east of the country, a few kilometres from the Iranian border. Dauletabad was discovered in 1974; production started in 1984 and it became a key source of supply to the Central Asia-Centre pipeline to southern Russia and Ukraine. Recoverable gas resources have been estimated in recent years at 0.9-1.7 tcm; the reservoir is at a depth of 2,800-3,000 metres, with 5,700 psi pressure. Although Dauletabad has been on stream for nearly 30 years, it is estimated to be only about one-third depleted, largely due to reduced production in the 1990s. At the height of the 2000s boom, Dauletabad was producing 28-31 bcm/year, i.e. just under half of Turkmenistan's total output. This was reduced by about two-thirds in 2009 , as a consequence of the reduction in Russian purchases, but is now assumed to be returning to previous levels. ${ }^{30}$

Since 2009, infrastructure has been built to carry Dauletabad gas to new export routes. The Dauletabad-Sarakhs-Khangiran pipeline to Iran was opened in January 2010, and extended a further $190 \mathrm{~km}$ to Sangbast, near Mashhad in Iran, in November of that year. In October 2011 a new compressor station, Dauletabad-2 (built by Enex Process Engineering of Belgium) was commissioned, with three units and a capacity of $20 \mathrm{bcm}$, to carry Dauletabad gas to the Turkmenistan-China pipeline - although it is not clear when and on what scale such deliveries will begin. ${ }^{31}$ The northbound pipeline that feeds Dauletabad gas into the Central Asia-Centre line has also been upgraded, with looping added to cut out a section of the line that briefly traverses Uzbek territory (to the Khiva compressor station). Turkmen official sources state the capacity of this line as $54 \mathrm{bcm} / \mathrm{year}^{32}$ It is probable that at present Dauletabad is supplying most of the Turkmen gas exported to and through Russia (estimated at $11 \mathrm{bcm}$ in 2012) and some of the exports to Iran (estimated at $8 \mathrm{bcm}$ in 2012).

The gas supplied by Turkmengaz to China (i.e. excluding that produced by CNPC) is sourced from two other eastern fields: Malay, the second largest producing field after Dauletabad, and the Uchadzi group. Malay, which prior to 2009 produced gas for delivery to Russia via the

\footnotetext{
${ }^{28}$ ENI web site, “Turkmenistan" page; Tsakiris (2012).

${ }^{29}$ US Energy Information Administration, “Turkmenistan Country Analysis"; Valdez and Weaver (2012), p. 285

${ }^{30}$ Bernstein Research (2011), p. 73; “Turkmenistan”, in Pirani (ed.) (2009) p.280

31 “Turkmenistan razvivaet moshch i vozmozhnosti gazovoi otrasli”, Neft' Gaz i mineral'nye resursy

Turkmenistana no. 3 2011, pp. 42-43; “GKS 'Dovletabad-2' stoimost'iu 132 mln evro vvedena v Turkmenistane”, Oil Capital 23 October $2011<$ http://www.oilcapital.ru/upstream/124112.html>

32 "Narastaet industrial'naia moshch' toplivno-energeticheskogo kompleksa Turkmenistana", Turkmenistan: zolotoi vek 21 October $2012<$ www.turkmenistan.gov.tm/?id=72>; "V Turkmenii vveli v ekspluatatsiiu GKS 'Dovletabad-2'”, Energo News (Moscow), 24 October 2011
} 
Central Asia-Centre pipeline, has been designated as the main source of Turkmengaz gas for China. In 2010, shortly after the Turkmenistan-China pipeline was opened, a $185 \mathrm{~km}, 1,420$ $\mathrm{mm}$ feeder line, linking the field to the Bagtyiarlyk compressor station from which the Turkmenistan-China pipeline starts, was completed by Stroitransgaz of Russia. ${ }^{33}$ The construction of a compressor station at the field, to raise the capacity of the feeder line to 30 $\mathrm{bcm} /$ year, has been highlighted as a priority by the Turkmen government since 2010 but is not yet completed; president Berdymukhammedov again referred to it as a priority in a key speech to the government in January $2012 .{ }^{34}$ The station is projected to gather gas both from Malay and from the Uchadzi fields (Uchadzi, East Uchadzi and Seirab) nearby. ${ }^{35}$

Other eastern fields that could supply either eastern or western routes include Bagadzha, an oil and gas field, and site of a gas processing plant that produces gas condensate for further processing at the Seidi oil refinery, and LPG. The first line of this plant was commissioned in 2006, the second in $2011 .{ }^{36}$ Also in the eastern region is the Naip group of fields, where some gas was produced from exploration wells in 2010, and where some processing capacity is available. $^{37}$

Turkmenistan's other onshore producing assets, in the western and south-western regions, include oil and gas fields and are operated by the state oil production company, Turkmenneft. Their aggregate output is much smaller than that of the eastern fields - probably up to 4-5 bcm for export southwards to Iran via the Korpedzhe-Kord Kuy pipeline, plus about the same amount for local domestic use. Turkmenneft's largest field is Korpedzhe, which reported production averaging more than $4 \mathrm{bcm} /$ year in the early 2000s; Turkmen official sources state that the pipeline accepts (i) gas from Korpedzhe, (ii) associated gas from Kamyshlydzha nearby, and (iii) gas from the Keimir, Akpatlavuk and Nebitlidzhe oil and gas fields in the Keimir area in the south west. Some associated gas in this region is flared; Turkmenneft states that flaring will be reduced by the construction of a new compressor station at Keimir, and by the introduction of gas-lift technology (which compresses gas and pumps it down oil wells to enhance oil recovery). ${ }^{38}$

\section{Production (onshore - CNPC's production sharing agreement)}

The production sharing contract (PSC) between CNPC and Turkmengaz, covering the very large Bagtyiarlyk contract area on the right bank of the Amu Darya river, is a key element in China's strategic partnership with Turkmenistan. The 35-year contract was signed in July 2007 between CNPC and the State Agency for the Management and Use of Hydrocarbon

\footnotetext{
${ }^{33}$ Stroitransgaz web site, "Gazoprovod Malai-Bagtyiarlyk", $<$ http://www.stroytransgaz.ru/projects/turkmenistan/malai-bagtyyarlyk>

34 “Turkmenistan narashchivaet svoi gazoeksportnye vozmozhnosti”, Neft', Gaz i mineral'nyie resursy Turkmenistana no. 3 2010, pp 72-73; press monitoring by British Embassy, Ashgabat

${ }^{35}$ State information agency of Turkmenistan, "2010 god v letopisi epokhi novogo vozrozhdeniia", 13 January $2011<$ http://th.gov.tm/?id=2426>

36 "Na mestorozhdenii Bagadzha vveden v stroi gazopererabatyvaiushchii kompleks", Turkmenistan.ru, 23 September 2006

$<$ http://www.turkmenistan.ru/index.php?page_id=3\&lang_id=ru\&elem_id=8638\&type=event $>$; "Narastaet industrial'naia moshch' toplivno-energeticheskogo kompleksa Turkmenistana”, Turkmenistan: zolotoi vek 21 October $2012<$ www.turkmenistan.gov.tm/?id=72>

37 State information agency of Turkmenistan, "2010 god v letopisi epokhi novogo vozrozhdeniia”, 13 January 2011, <http://th.gov.tm/?id=2426>

38 “Turkmenneft': dinamika razvitiia”, Turkmenistan August 2006 no. 16-17; presentation by Oraz Orazov, Director, Nebitgazylmytaslama Institute, at the Turkmenistan International Oil and Gas Exhibition (TIOGE) 2011
} 
Resources, and covers $14,300 \mathrm{sq} \mathrm{km}$, i.e. all of Turkmen territory between the Amu Darya river and the border with Uzbekistan (see map 2). There are two blocks, A and B, with separate sets of commercial terms; block A, covering about $1,000 \mathrm{sq} \mathrm{km}$, is explored and developed to a much greater extent than block B; reserves for the entire area are estimated at $1.3 \mathrm{tcm}$. In 2009, the rights in the PSC were valued at $\$ 1.187$ billion in an intra-company transaction (purchase of the rights by PetroChina, a CNPC subsidiary, from its parent company). ${ }^{39}$ A $70.5 \mathrm{Mw}$ compressor station at Bagtyiarlyk, opened in September 2010, takes gas from both CNPC's contract area and the Malay and Uchadzi fields (see above), for transmission to China. ${ }^{40}$

CNPC aims to reach peak production of $13 \mathrm{bcm} /$ year by the end of 2012; production began in 2010 and cumulative output had reached $10.5 \mathrm{bcm}$ in mid 2012. CNPC states that its development work has been focused on the Samandepe gas field in Block A, where "efficient and orderly seismic acquisition and drilling" has led to significant increases in reserves, and capacity expanded with new wells. CNPC gives the daily average output of its new wells as 1-2 mmcm. But perhaps most significant is CNPC's success in raising production from individual wells by renovation, with daily average capacity per mature well more than doubling, from $300,000 \mathrm{cu} \mathrm{m}$ to $650,000 \mathrm{cu} \mathrm{m}$, as a result of new acidising techniques and optimal re-perforation measures. ${ }^{41}$ This may reflect the capacity for heightened efficiency throughout Turkmenistan's gas fields if the correct technology and field management techniques are applied.

Gas processing, as well as production facilities, needs to be completed before the Amu Darya project reaches peak output. The first of two planned gas processing plants, which with 5 bcm/year capacity CNPC states is the largest in Central Asia, was built by Chungqing Drilling Engineering Co and commissioned in December 2009 together with the pipeline to China. A second plant, with a projected capacity of $9 \mathrm{bcm} / \mathrm{year}$, is due for completion in 2013-14 (one line in June 2013 and a second in June 2014). ${ }^{42}$

\section{Production (offshore)}

Two foreign companies - Petronas of Malaysia and Dragon Oil of Dubai, who signed PSAs in 1996 and 1999 respectively - are now producing gas in offshore blocks in the Caspian Sea. Petronas is producing considerable volumes of natural gas $(3 \mathrm{bcm}$ in 2011 , and potentially as much as $10 \mathrm{bcm} /$ year in future); Dragon's gas is associated with its oil production. But the common problem for both companies is the lack of a market for the gas: physically, it can be exported southwards to Iran or, with the necessary enhancement of infrastructure, northwards to Russia, or it can be sold in the domestic market. But the glut of local supply that resulted from the fall in Russian purchases - which in the west of Turkmenistan cannot be eased by exporting gas to China or to other Central Asian countries - raises the prospect that the gas could be stranded.

\footnotetext{
${ }^{39}$ PetroChina, Connected Transaction: Acquisition of Rights Under Product Sharing Contract (Hong Kong stock exchange filing); Bernstein Research, The Caspian, p. 85.

40 “Turkmenistan narashchivaet”, Neft', Gaz i mineral'nyie resursy Turkmenistana, op. cit.

41 "CNPC in Turkmenistan" page of the CNPC web site

$<$ http://www.cnpc.com.cn/en/cnpcworldwide/turkmenistan/Turkmenistan.htm?COLLCC=160372454\&>

${ }^{42}$ Presentation by Lu Gongxun, General Director, CNPC Turkmenistan,TIOGE 2011; “Otkryto mestorozhdenie gaza 'Agairy",, Neft', Gaz i mineral'nyie resursy Turkmenistana no. 3 2010, p. 77; "V Turkmenii nachalos stroitel'stvo novogo GPZ”, Energyland.info, 14 December $2011<$ http://www.energyland.info/news-print80733>
} 
In July 2011, Petronas started production from its Block 1 PSA of oil $(6,000 \mathrm{bpd})$, gas condensate (20,000 bpd) and gas (at the estimated rate of $3 \mathrm{bcm} /$ year). The gas, some natural and some associated, goes to an onshore terminal at Kianly (with a capacity of $5 \mathrm{bcm} /$ year), where there is processing capacity. From there it goes into the Caspian Littoral pipeline, which runs south to the Iranian border. In 2011 Petronas signed a sale-purchase agreement with Turkmengaz, the terms of which are not disclosed. In particular, it is not clear whether Petronas has agreed on terms with Turkmengaz that reflect export prices. But Petronas representatives have indicated (a) that the start-up was delayed from the start of 2011, due to the lack of agreement on terms for marketing the gas, and (b) that its readiness to raise output in future depends on the type of commercial agreements it can achieve. Sharbini Suhaili, Petronas vice president, told an industry conference in 2011: "We could raise production to $7.5 \mathrm{bcm}$ or even $10 \mathrm{bcm}$. It all depends on whether it is economically viable." 43 It may be inferred that Turkmengaz, for quite obvious commercial reasons, is hesitant to conclude longterm agreements to purchase larger volumes of gas, given that it shut in some of its own production after the fall in Russian purchases; moreover, the Turkmen authorities are unlikely to agree to Petronas exporting its own gas, as this would break Turkmengaz's de facto export monopoly and allow a competitor into the oversupplied Russian market.

Dragon Oil, which operates the Cheleken contract area in the Turkmen Caspian under a 25year PSA effective from 2000, has been flaring some gas (less than $1 \mathrm{bcm} /$ year) associated with its oil production, which has been rising and reached 70,000 bpd in 2011. Some of Dragon's associated gas is delivered, without processing, into the domestic distribution network via a gas compressor station at Hazar. But in order to reduce flaring further, (i) a gas treatment plant needs to be built, and a tender for a $2.3 \mathrm{bcm} /$ year plant was due to be held in 2012 and construction is expected to take two or three years, and (ii) a sales agreement needs to be reached, presumably with Turkmengaz. Dragon has reported in recent annual reports and conference presentations that negotiations with Turkmengaz on monetisation of the gas are ongoing; in November 2012 the company stated that "the discussions on a gas agreement are subject to demand for gas in the region, which is weak at the moment". 44

The problem with Dragon Oil's associated gas is essentially the same as with Petronas's production - that while Turkmengaz's own exports westward have been depressed so sharply, and Russian demand for Turkmen gas remains minimal, it is difficult to see any motivation for Turkmengaz to buy the gas, or any immediate prospect of access to export markets. As map 2 shows, without substantial investment in infrastructure, the western and Caspian offshore resources cannot form part of the export volumes to China. Over the long term, one possibility is that - should Chinese demand remain strong, and the Turkmen westeast pipeline (discussed below in section 5.3) be completed - gas could be transported across Turkmenistan in an eastward direction, rather than in a westward direction as was contemplated when the pipeline was planned.

South Yolotan (Galkynysh)

Turkmenistan's importance as a source of gas over the long term was substantially enhanced in 2011, when the South Yolotan field was confirmed to be the second largest in the world (after the South Pars (Iran)-North (Qatar) field in the Persian Gulf). The name South Yolotan is often used to denote three adjacent fields: South Yolotan (by far the largest), Osman and

\footnotetext{
43 “Petronas's Caspian Block Delay", Platt's International Gas Report, 14 March 2011, p. 20; "Petronas starts Caspian Block 1", Platt's International Gas Report, 15 August 2011; author's notes from TIOGE, 2011

${ }^{44}$ Dragon Oil Annual Reports 2008, 2009, 2010 and 2011, and 2012 interim report; author's notes from TIOGE 2011; email from Dragon Oil to the author, November 2012
} 
Minara. A fourth field, Yashlar, was in 2011 confirmed to be a separate geological structure, and is itself one of the 20 largest gas fields in the world. In November 2011 the area, including all four fields, was renamed Galkynysh (Renaissance) by the Turkmen government. ${ }^{45}$ Turkmengaz, which holds the licence to the area, employed Gaffney Cline \& Associates (GCA) to review data from its exploration wells at the field and to produce estimates on that basis. By 2011 GCA was able to estimate the aggregate of South Yolotan and Yashlar reserves at 14.55-26.2 tcm, with a best estimate of $19.05 \mathrm{tcm}$. The two sets of results made public by GCA are shown in Table 8.

Table 8: Gaffney Cline \& Associates Survey Results of South Yolotan and Yashlar Gas Fields

\begin{tabular}{|l|l|r|r|}
\hline \multicolumn{2}{|l|}{$\begin{array}{l}\text { Trillions of cubic metres } \\
\text { (tcm) }\end{array}$} & \multicolumn{1}{l|}{$\begin{array}{l}\text { 2008 } \\
\text { results }\end{array}$} & \multicolumn{1}{l|}{$\begin{array}{l}\text { 2011 } \\
\text { results }\end{array}$} \\
\hline South Yolotan & Low & 4 & 13.1 \\
\cline { 2 - 4 } & $\begin{array}{l}\text { Best } \\
\text { estimate }\end{array}$ & $\mathbf{6}$ & $\mathbf{1 6 . 4}$ \\
\cline { 2 - 4 } & High & 14 & 21.2 \\
\hline \multirow{3}{*}{ Yashlar } & Low & 0.3 & 1.45 \\
\cline { 2 - 4 } & $\begin{array}{l}\text { Best } \\
\text { estimate }\end{array}$ & $\mathbf{0 . 7}$ & $\mathbf{2 . 6 5}$ \\
\cline { 2 - 4 } & High & 1.5 & 5.0 \\
\hline \multicolumn{2}{|l}{ Total, best estimate } & $\mathbf{6 . 7}$ & $\mathbf{1 9 . 0 5}$ \\
\hline
\end{tabular}

Source: presentation by Jim Gillett, GCA, at the Turkmenistan Oil \& Gas Conference, 16 November 2011, Ashgabat

The first set of estimates, made public in 2008, put South Yolotan's reserves at 4-14 tcm, and Yashlar's at 0.3-1.5 tcm. GCA stated that the estimates were based on data from nine wells at South Yolotan and four at Yashlar, 1,000 sq km of 3D seismic and some regional 2D seismic. The two areas of greatest uncertainty were the depth of the gas-water contact (i.e. the top of the water layer beneath the gas in the reservoir), and the reliability of the structural definition to the north-west of the field, i.e. the Minara structure. In 2011, GCA published a second set of estimates, based on data from 19 wells at South Yolotan, including two that had reached the gas-water contact, eight wells at Yashlar, 2,000 sq km of 3D-seismic, and 1,800 km of 2D seismic, shot by Turkmengaz at South Yolotan, and $574 \mathrm{sq} \mathrm{km}$ of 3D-seismic and 1,500 km of 2D-seismic shot at Yashlar. ${ }^{46}$

Jim Gillett of GCA told an industry conference in Ashgabat ${ }^{47}$ : "The basic change is that the gas-water contact is deeper than we thought. There has been speculation that we didn't have enough data, or didn't do our own analysis. I am happy to confirm that - with the caveat that no geologist is ever going to say he has enough data - we had sufficient information to update our 2008 results. There is no doubt that South Yolotan is the second largest field in the world." He said that $8-14 \%$ of the volume of the "raw" gas is hydrogen sulphide and carbon dioxide, and that the reservoir is overlain by salt. The salt layer presents drilling challenges:

\footnotetext{
45 "Sverkhgigantskoe gazovoe mestorozhdenie v Turkmenistane", Turkmenistan.ru, 20 November 2011

$<$ http://www.turkmenistan.ru/ru/articles/36728.html>

${ }^{46}$ Presentations by Jim Gillett, GCA, at TIOGE 2010 and 2011

${ }^{47}$ Ibid
} 
at depth and under pressure salt behaves as a plastic; wells have to be cased with steel and cement, because wells without casing will slowly cave in.

In 2011 a measure of confusion was introduced into the discussion about South Yolotan's reserves, firstly by Gazprom, some of whose senior managers claimed that Soviet-era data showed that the reserves did not exist, and also by some Turkmen officials, who cited unexplained numbers in media interviews prior to the publication of GCA's estimates. These doubts have largely been put to rest by the publication of the estimates shown in Table 8, and their acceptance by the BP Statistical Review of World Energy in its 2012 edition. Cedigaz, in its published review of world natural gas reserves, reports Gaffney Cline's estimates, and states that South Yolotan is the second-largest field in the world, but has restated Turkmenistan's total reserves more conservatively, at $10 \mathrm{tcm}$ in contrast to BP's figure of $23.4 \mathrm{bcm}$. Cedigaz states that "development of the field will be challenging because of high pressure reservoirs and a high proportion of acid gases $[\ldots]$ and the recovery factor remains uncertain." 48

The magnitude of hypothetical production from a 19 tcm field may be illustrated as follows. ${ }^{49}$ If it were assumed to produce at a plateau equivalent to $3 \%$ of reserves for 20 years (following a 10 year production build-up phase), and decline post-plateau at a rate of $10 \%$ per year, the peak production would be $570 \mathrm{bcm} /$ year. This compares with this author's projection of a requirement for $110 \mathrm{bcm} /$ year of total Turkmen production at some point in the $2020 \mathrm{~s}$, and the government's publicly stated target of $230 \mathrm{bcm} /$ year of total Turkmen production by 2030 . The actual production profile will be decided by above-ground factors including Turkmenistan's capacity for managing the field and how this fits in to its political and economic strategies.

In December 2009 Turkmengaz signed service contracts to develop the South Yolotan field with foreign contractors, worth $\$ 9.74$ billion in total, as follows: $\$ 3.128$ billion CNPC (China), \$3.979 billion Petrofac International (UAE), \$1.15 billion Gulf Oil \& Gas (UAE) and $\$ 1.485$ billion consortium of LG International and Hyundai Engineering (South Korea). The work is being undertaken as indicated in Table 9. Turkmen official sources have indicated that the first phase of development will be completed in 2014, and the second phase will start in that year; in November 2012, the president of Turkmengaz stated that first gas would be produced from the field in $2013 .{ }^{50}$ A third phase will be implemented "if necessary", and the field is expected to reach peak output of around $70 \mathrm{bcm} /$ year in 2020-22.

\footnotetext{
${ }^{48}$ See, for example, Posaner and Korobov (2012), p. 1. Cedigaz (2012), pp. 19-20.

${ }^{49}$ With thanks to Howard Rogers

50 “Gaz s samogo krupnogo mestorozhdeniia v Turkmenistane nachnut dobyvat' v 2013 godu”, Kursiv, 20 November 2012.
} 


\section{Table 9: Infrastructure Construction at South Yoltan Field}

\begin{tabular}{|c|c|c|}
\hline Field development & $\begin{array}{l}\text { Gas gathering } \\
\text { pipeline } \\
\text { infrastructure }\end{array}$ & $\begin{array}{l}\text { Gas processing } \\
\text { plant }\end{array}$ \\
\hline $\begin{array}{l}\text { CNPC (China) } \\
10 \text { bcm } \\
\text { (28 production wells) }\end{array}$ & $\begin{array}{l}\text { CNPC (China) } \\
10 \mathrm{bcm}\end{array}$ & $\begin{array}{l}\text { CNPC (China) } \\
10 \mathrm{bcm}\end{array}$ \\
\hline \multirow{2}{*}{$\begin{array}{l}\text { Gulf Oil \& Gas } \\
20 \text { bcm } \\
\text { (up to } 40 \text { production } \\
\text { wells) }\end{array}$} & \multirow{2}{*}{$\begin{array}{l}\text { Petrofac } \\
\text { International } \\
\text { (UAE) } \\
20 \mathrm{bcm} \text { (four units) }\end{array}$} & $\begin{array}{l}\text { Petrofac } \\
\text { International } \\
\text { (UAE) } \\
10 \mathrm{bcm}\end{array}$ \\
\hline & & $\begin{array}{l}\text { LG International } \\
\text { and Hyundai Eng. } \\
\text { (Korea) } \\
10 \mathrm{bcm}\end{array}$ \\
\hline
\end{tabular}

Source: press reports, company announcements and presentations

The South Yolotan development has further cemented the Turkmen-China partnership. Turkmenistan sees the purpose of South Yolotan as to supply the Chinese export route, and China has given substantial financial support to the project, in the form of two major project loans by the China Development Bank to Turkmengaz - $\$ 4$ billion in 2009, and a further $\$ 4.1$ billion in April 2011. Officials from both sides have stated that the first loan is to be repaid with deliveries of natural gas. ${ }^{51}$ While tension between the two sides is possible specifically, over pricing (see section 5.2 below) - there seems little doubt that development of the field, combined with the Turkmen-China pipeline, will substantially redraw the energy map of Asia for the coming decades, with Turkmenistan's main export route shifting from Russia to China.

\section{Other developments}

Turkmen official sources indicate that, as well as South Yolotan and Yashlar, some other small fields are in development. In central Karakumy, $3 \mathrm{bcm}$ of gas processing equipment, and a $5 \mathrm{bcm}$ pipeline linking to the Central Asia-Centre line, were commissioned in 2010, in preparation for production to start up from 16 small fields in the area. The Garabil gas condensate field, near Dauletabad, was in 2011-12 linked to Gurrukbil and Dauletabad with a $42 \mathrm{~km}$ pipeline, supplied by two gas condensate wells and scheduled to be supplied by another eight. Annual output of $1 \mathrm{bcm}$ is projected. ${ }^{52}$

\footnotetext{
${ }^{51}$ Nadia Rodova, “Beijing lends Ashgabat \$4.1 bn”, Platt's International Gas Report, 9 May 2011, p. 14; author's meeting with representatives of the Chinese diplomatic corps in Turkmenistan, November 2010

52 “Osvaivaiutsia gazovye resursy Karakumov”, Neft', Gaz i mineral'nyie resursy Turkmenistana no. 3 2010, pp. 74-75; State information agency of Turkmenistan, "2010 god v letopisi epokhi novogo vozrozhdeniia", 13 January 2011, <http://tdh.gov.tm/?id=2426>; British embassy in Turkmenistan, Updates on the Energy Sector, February 2012
} 


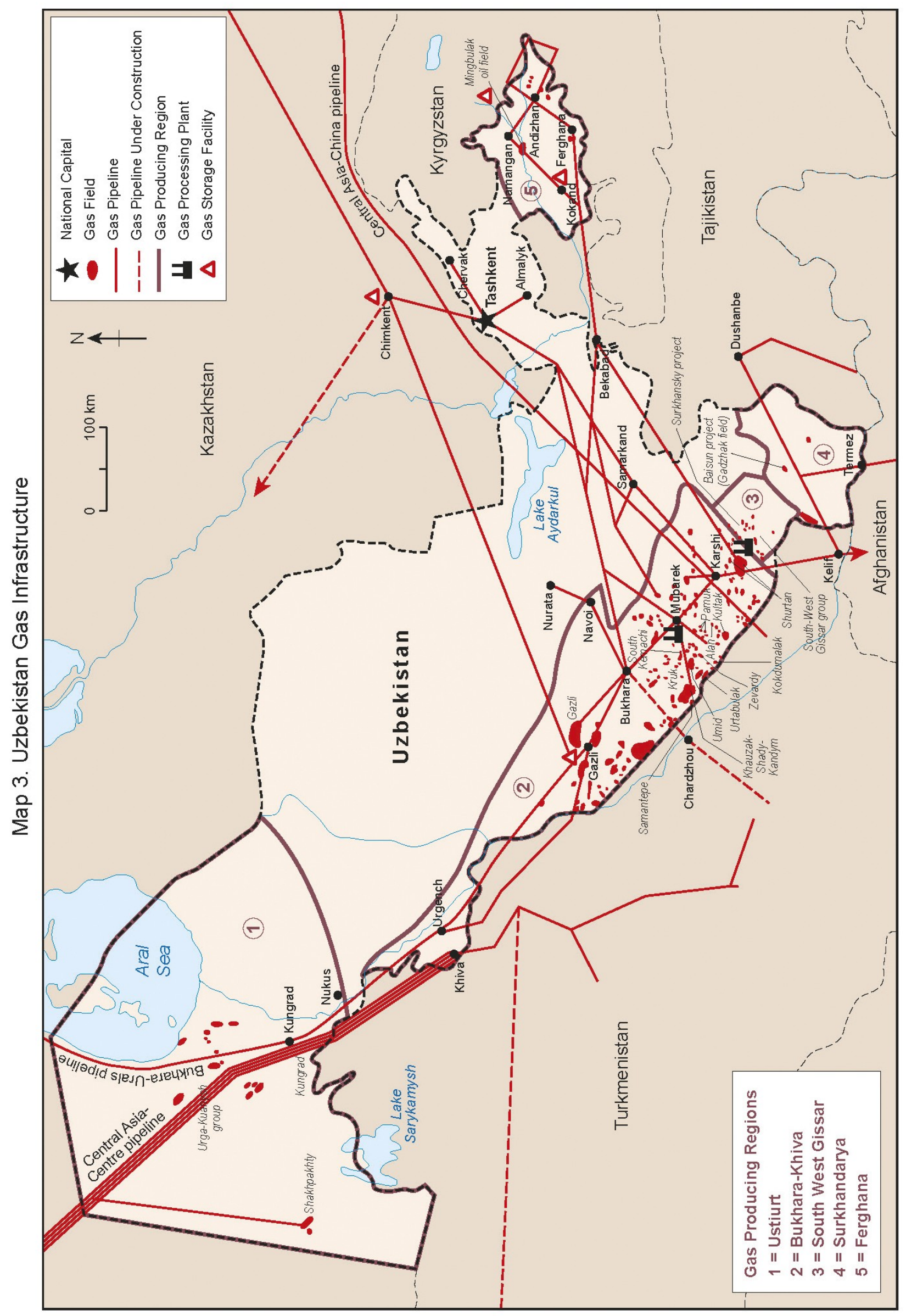




\subsection{Uzbekistan}

Uzbekistan is currently the largest gas producer in Central Asia, with estimated annual output of 58-66 bcm of sales gas over the last decade. In 2002-08 Turkmenistan and Uzbekistan produced similar volumes - but at times when Turkmenistan's production was reduced due to the lack of export markets, in 1994-2002 and again after the reduction of purchases by Russia in 2009, Uzbekistan's production surpassed it. Uzbekistan has always had far less gas available for export than Turkmenistan, though, because of its high, inefficient domestic consumption, estimated at $44-50 \mathrm{bcm} /$ year over the last decade (see section 4.1 below).

More than two thirds of Uzbek gas is produced in the Bukhara-Khiva region in the south of the country. Smaller volumes are produced in the Ustiurt region in western Uzbekistan. In order to maintain or increase output, Uzbekistan is relying not only on development work underway in new fields in Bukhara-Khiva and Ustiurt, and in new fields in the south-eastern and eastern regions, but also on the application of enhanced recovery techniques to existing fields.

Uzbekistan exports gas to Russia via the Central Asia-Centre pipeline system and the Bukhara-Urals pipeline, and in 2012 started to export very small volumes to China via the Turkmenistan-China pipeline. Uzbek gas is also supplied to south-east Kazakhstan, and to Tajikistan and Kyrgyzstan, under arrangements inherited from the Soviet period - although both Uzbekistan and these importers have found, or are seeking, arrangements to reduce their mutual trade obligations. However for the foreseeable future the main call on Uzbek gas, and the main factor limiting its capacity to export gas, will be its domestic consumption. This section covers the historical and political background, and surveys production and development region by region.

\section{Historical and political context}

Gas production began in Uzbekistan in the 1950s, and Gazli in the Bukhara-Khiva region was the largest producing field in the Soviet Union throughout the 1960s. The Bukhara-Urals and Central Asia-Centre pipelines (first lines commissioned in 1962 and 1967 respectively) were built to supply gas from both Uzbekistan and Turkmenistan to the USSR's largest industrial regions. In 1992, Uzbekistan became independent and adopted an autarchic economic policy that prioritised self-sufficiency and import substitution (see section 2 above). Uzbekistan, even more than other post-Soviet states, used its gas as a subsidy for local industry and the population. It also began to divert resources away from cotton, its main Soviet-era export, and sought to build up its hydrocarbons processing capacity and automobile production. All these policies increased domestic demand for gas. The vast majority of exploration, field development and production in the post-Soviet period has been undertaken by the stateowned oil and gas company, which was reorganised in 1998 under its present name, Uzbekneftegaz. Uzbekistan has limited the involvement of foreign companies in the oil and gas sector, in keeping with its policy of self-sufficiency and its view of the sector as a strategic one. In the mid 1990s some large US, Saudi and other companies were active in Uzbekistan, but foreign involvement essentially came to a halt in the late $1990 \mathrm{~s}$, as international oil prices fell and Uzbek production of both oil and gas declined. ${ }^{53}$

A new chapter of Uzbek-foreign cooperation opened in the mid 2000s, as oil prices, and Russian demand for Central Asian gas, rose. Uzbekistan began to negotiate production

\footnotetext{
${ }^{53}$ See Zhukov (2009), pp. 373-374.
} 
sharing agreements with foreign companies, and Gazprom and Lukoil of Russia became the largest investors in the Uzbek upstream. There was something of a false start in 2001, when Uzbekistan signed its first upstream PSA, for the development of the South West Gissar group of fields, with Uzbekneftegaz and UzPEC, a subsidiary of Trinity Energy of the UK. First oil was produced in 2002, but in 2004 Uzbekneftegaz dissolved its partnership with Trinity, stating that contractual terms had been breached; ${ }^{54}$ Soiuzneftegaz of Russia took control of UzPEC; and in 2008 Lukoil bought out Soiuzneftegaz's interest in the project. ${ }^{55}$ Much more significant and successful was the PSA signed in 2004 between Uzbekistan and Lukoil for the development of the Khauzak, Shady and Kandym fields in Bukhara-Khiva region, which are projected to achieve $11 \mathrm{bcm} / \mathrm{year}$ of gas production at peak, and the Kungrad field in Ustiurt. ${ }^{56}$ In 2004, Uzbekistan also signed a PSA with two Gazprom subsidiaries (Zarubezhneftegaz and Gas Project Development Central Asia (GPD)) to redevelop the Shakhpakhty deposit in Ustiurt region, which had been in production between 1971 and 2002. Finally, in 2006, Uzbekistan signed a PSA with an international consortium to explore the Uzbek section of the Aral Sea.

Since the late 2000s, all the signs are that Uzbekistan's gas production is in decline. The US EIA statistics used in the gas balance (Table 1 above) indicate a fall in total output (including gas reinjected and flared) from $68.6 \mathrm{bcm}$ in 2008 to $61.6 \mathrm{bcm}$ in 2010 . News outlets, quoting official sources, reported that production was $2.1 \%$ lower in 2010 than in 2009 , and $4.1 \%$ lower in the first half of 2011 than in the first half of $2010 .^{57}$ This fall in output is due largely to the natural decline of old fields, which is apparently exacerbated by limited use of enhanced recovery techniques in the past. It comes at a time when demand, and potential demand, is being driven upwards. Given these circumstances, Uzbekistan has again - in spite of its emphasis on self-sufficiency - sought to bring in foreign companies, usually on the basis of PSAs or service contracts, both to develop new fields and to enhance production at existing ones.

During this latest phase of Uzbek efforts to attract foreign investment, the sources of the investment have shifted in three ways: The Swiss-based company Zeromax went bankrupt and its Uzbek upstream assets passed to others; among Russian investors, while Lukoil's investments in Uzbek gas have risen - in line with its stated intention of exporting gas from Uzbekistan to China - Gazprom's have been reduced; by far the most significant, there has been a surge of Asian investment.

The bankruptcy of Zeromax appears to have resulted from a failed attempt by members of the Uzbek elite to establish private ownership of oil and gas assets, in a manner similar to that used in Russia and other post-Soviet states in the 1990s. This attempt ran counter to the prevailing policy of Uzbekistan's government, which, like Turkmenistan's, has sought to retain control of the energy sector through state-owned entities. Whereas Zeromax presumably acquire its upstream assets in "insider privatisations" similar to those in Russia and Kazakhstan, its bankruptcy appears to amount to a reaffirmation in practice that - while

\footnotetext{
54 “"Soiuzneftegaz' prosiat osvobodit' ploshchad”, Kommersant, 14 February 2005; "Rossiia. Ofitsial'nyi vizit. Strategicheskie resheniia”, Novosti Uzbekistana, 22 February 2008

$<$ http://www.novostiuzbekistana.st.uz/8_394/ru.htm>

${ }^{55}$ Zhukov (2009), p. 380; A. Strokov and V. Paramonov, "Evropeiskoe prisutstvie v energetike Uzbekistana, Kyrgystana i Tadzhikistana: obshchie napravaleniia, perspektivy i riski”, Tsentral'naia Evraziia, 6 March 2012

${ }^{56}$ Lukoil Overseas Holding Ltd, Corporate Report 2010, p. 35

${ }^{57}$ Neftegazexpert, "Ukrainskii Turbogaz vyigral tender na postavku oborudovaniia”, 30 April 2011, $<$ http://www.neftegazexpert.ru/neftegazline/neftegaztext110164.html>; "UNG rekonstruiruet DKS na Shurtanneftegaze za \$48m”, 19 Sep 2011, http://www.oilcapital.ru/industry/35587.html
} 
Uzbekistan is ready to work with some foreign investors - Uzbek interests in the energy sector will be held through state rather than private companies. Zeromax, founded in 2001 and presumed to be owned by members of the Uzbek elite, entered the upstream in 2004 via stakes in two joint ventures with Gazprom subsidiaries, Gissarneftegaz and Kokdumalakgaz, which both produce gas from Bukhara-Khiva fields. (It also owned other assets, e.g. part of an LPG production business, a network of petrol stations, and stakes in the gold mining sector.) In May 2010 Zeromax was declared bankrupt, with reported debts of $\$ 500$ million. Some of Zeromax's upstream assets had come under the control of Gazprom-Germania, the Gazprom subsidiary that works in the Central Asian upstream. ${ }^{58}$

The replacement of Gazprom by Lukoil as the largest foreign investor in the Uzbek upstream is a reflection of developments in the Russian gas sector, where non-Gazprom producers including Lukoil and other oil companies - now account for more than one-quarter of Russian gas output, and have lobbied successfully for changes to gas industry regulation to ensure access to local industrial consumers. Lukoil's senior managers have made clear from 2004, when they signed the Khauzak-Shady-Kazym-Kungrad PSA, that they viewed their Uzbek investment as a key to opening up Asian gas markets. In 2010, Vagit Alekperov, Lukoil's CEO, announced that the company had made a "provisional" agreement with Chinese buyers to sell future gas from its Uzbek PSAs to China (although negotiations with Uzbekneftegaz about the terms of export sales agreements are understood to be continuing). Alekperov said in 2012 that Lukoil expects to raise gas production in Uzbekistan from around $3 \mathrm{bcm} /$ year currently to $17-18 \mathrm{bcm} /$ year by $2017 .{ }^{59}$ Gazprom has retained shares in the Kokdumalak, Gissarneftegaz and Shakhpakhty projects, and continues to conduct exploration under a long-term partnership agreement with Uzbekneftegaz, but on the other hand has relinquished licences in the Urga-Kuanysh area in Ustiurt on the grounds that they cannot be developed economically; these are now being explored and developed by Petronas under a PSA signed in 2009. Moreover, Gazprom's share of the output of the Uzbek projects in which it participates is estimated at less than $1.5 \mathrm{bcm} /$ year in total and less than $0.75 \mathrm{bcm}$ of that is exported; the remainder of Gazprom's gas purchases from Uzbekistan are reportedly made directly from Uzbekneftegaz. Gazprom's holdings in Uzbekistan are set out in Appendix 4.

The rise of Asian investment in the Uzbek upstream reflects both the broad trend of increased Chinese and east Asian economic ties with Central Asia, and China's specific interest in Uzbekistan as a potential supplier of export volumes via the Turkmenistan-China pipeline. CNPC and Petronas are both involved in exploration and development of gas in Uzbekistan, although not yet producing on the scale that they are in Turkmenistan. Both those companies, together with Korea National Oil Corporation, Lukoil and Uzbekneftegaz, are participating in the Aral Sea consortium that in 2006 signed a PSA with the government. Also in 2006, CNPC signed an oil and gas exploration agreement with Uzbekneftegaz, covering five onshore blocks totalling 34,000 sq km. In 2008 the two companies agreed to boost the output of mature oilfields in the Ferghana basin and set up a joint venture to work there. ${ }^{60}$ Petronas is undertaking exploration in Ustiurt, under the Urga-Kuanysh PSA mentioned above, and in 2010 signed a PSA covering the Baisun field in the Surkhandarya region, where it also has an

\footnotetext{
${ }^{58}$ Zhukov (2009) pp. 376-378; Lenta.ru, "Sud Uzbekistana pristupil k bankrotstvu dvukh struktur Gazproma”, 10 September 2010; Neftegazexpert, "Gazprom kupit neftegazovye aktivy”, 2 Feb 2007,

$<$ http://www.neftegazexpert.ru/neftegazline/neftegaztext20287.html>; Gazprom Germania Management Report for 2010, p. 16

59 “Lukoil offers Uzbek gas to China”, Platt's International Gas Report, 11 October 2010; “Lukoil nameren cherez 10 let dobyvat", 22 Feb 2012, www.angi.ru

${ }^{60}$ CNPC web site, "Uzbekistan” page
} 
exploration agreement covering the Surkhansky field nearby. ${ }^{61}$ Aggregate output from those fields, when developed, is projected at 3-3.5 bcm/year. Korean companies and financial institutions, and the Asian Development Bank, are in talks the Uzbek government and Uzbekneftegaz about investment in petrochemicals projects (see section 4.1 below) that would require substantial upstream gas development for their success; the most far advanced of these would be sited at the Surgil field in Ustiurt. The substantial investments by Asian companies contrast sharply with the minimal activity by western oil companies in Uzbekistan; only one, Tethys Petroleum, is known to be working in the country, at the Urtabulak field in Bukhara-Khiva.

An unresolved issue that hangs over Uzbekistan's gas production in the coming years is how Uzbekneftegaz and its foreign partners will strike a balance between production for export and production for the domestic market. By the end of the decade, foreign companies are likely to be producing more than $20 \mathrm{bcm} /$ year of gas, i.e. Lukoil, 17-18 bcm/year; Gazprom, $1.5 \mathrm{bcm} /$ year; Petronas, 3-3.5 bcm/year; CNPC unknown. There is no doubt that all of these companies hope to export this gas; Lukoil's senior executives have said so explicitly. That would imply incremental exports of at least 17 bcm/year (Lukoil 14-15 bcm/year; Petronas 3$3.5 \mathrm{bcm} /$ year; CNPC unknown). The Uzbek government is sure to see such exports as being in its interests too, provided that total production rises far enough to cover both these incremental exports, and domestic demand at roughly the current level (as argued in section 4.1 below, it is unlikely to fall significantly). This implies that the natural decline of Uzbekneftegaz's major fields must be covered mainly by enhanced recovery or by development of its own new production. Since there is little public information about the rate of decline of existing fields, or of Uzbekneftegaz's projections for enhanced recovery implementation and new field development, this author cannot comment on the scale of that problem. What can be said is that, by and large, the foreign companies' capital and technology are not being applied to it.

Uzbekistan's oil and gas fields are divided administratively into five geographical regions (see map 3). The remainder of this section describes the main producing fields in turn.

\section{Bukhara-Khiva region}

Most gas production, $45-50 \mathrm{bcm} /$ year of $60-70 \mathrm{bcm} /$ year in total, comes from the BukharaKhiva region, almost entirely from fields operated by Uzbekneftegaz. Uzbekistan's oil and gas fields are all small by international standards, and Uzbekneftegaz has constantly to manage the decline of some fields, the opportunities for enhanced recovery, and the need to develop new fields. Currently, the most significant producing fields are Shurtan, Kultak, Alan, Zevardy, Umid, South Kemachi, Kruk, Urtabulak and Gazli. ${ }^{62}$ There are significant technological problems: the gas is of poor quality, most of it containing relatively high concentrations of hydrogen sulphide; there is also some liquids content. Uzbekneftegaz also regularly undertakes projects to modernise infrastructure at these fields, most of which have been producing since the 1970s. Uzbekistan's two major gas processing plants, Mubarek (commissioned 1973, capacity for $30 \mathrm{bcm}$ of feedstock) and Shurtan (commissioned 1980,

\footnotetext{
61 “Petronas v Uzbekistane: vzaimovygodnoe partnerstvo", Uzbekskii zhurnal neft i gaza, May 2012, pp. 71-72

${ }^{62}$ Uzbekistan does not release field-by-field information consistently. In 1990, Shurtan, Zevardy and Dengizkul'-Khauzak accounted for $75 \%$ of production; in the early 2000 s, those three fields plus Alan, Kokdumalak, Pamuk and Kultak accounted for 95\% of production; in 2011, media citing official sources reported that Shurtan, Kultak, Alan, Zevardi, South Kemachi and Umid accounted for 48.5 bcm. Zhukov (2009) pp. 360-361; Neftegazexpert, "Ukrainskii Turbogaz vyigral tender na postavku oborudovaniia", 30 April 2011, $<\mathrm{http}: / / w w w . n e f t e g a z e x p e r t . r u / n e f t e g a z l i n e / n e f t e g a z t e x t 110164 . h t m l>$
} 
capacity for $24 \mathrm{bcm} /$ year of feedstock) are in the Bukhara-Khiva region, and are supplied by gas from all its fields. Their output includes dry gas, stable gas condensate and liquefied petroleum gas (LPG). At Shurtan there is also a gas chemical complex that started operation in 2001; its annual installed capacity is $4.5 \mathrm{bcm}$, from which it produces refined gas, polyethylene, $\mathrm{LPG}$, gas condensate and granulated sulphur. ${ }^{63}$

In recent years, much effort has been focused in Bukhara-Khiva on the increasingly severe problem of falling pressure at aging fields. In 2011, Uzbekneftegaz officials announced a $\$ 783$ million investment programme into enhanced recovery techniques, to be implemented in 2012-15. Turbogaz of Ukraine won a tender to supply turbo-expanders, to be installed at the surface, to increase flow rates at Shurtan, Kultak, Alan, Zevardy, Umid and South Kemachi. In 2012 Uzbekneftegaz officials announced that a foreign partner was sought to work on utilisation (i.e. compression, and extraction of liquid hydrocarbons) of low-pressure associated gas at the South Kemachi, Kruk, Western Kruk, North Urtabulak and Umid fields. ${ }^{64}$ Another announcement indicated that new exploration methods would be applied at the Shurtan, Alan and Samantepe fields, with a view to increasing the level of recoverable reserves. ${ }^{65}$ At Shurtan, historically one of Uzbekistan's largest fields, a new 15 bcm/year compressor station is under construction, which will replace six old units with an aggregate capacity of $12 \mathrm{bcm} /$ year. ${ }^{66}$ At Gazli, which in the 1970s was the largest producing field in the Soviet Union but is now in decline, a new compressor station became operational in 2008, replacing worn-out units and raising the rate at which gas could be extracted at the field; compressors at the Pamuk field were replaced in the same year. ${ }^{67}$ Petronas representatives state that they are in discussion with Uzbekneftegaz about enhanced recovery projects at Gazli.

In addition to Uzbekneftegaz's own production in Bukhara region, there are fields it operates jointly with Lukoil under a PSA and with Gazprom subsidiaries and others as joint ventures. The largest of these, the Kandym-Khauzak-Shady project, is being developed under a 35-year PSA, effective from November 2004, in which Lukoil (via its Lukoil Overseas division) has a $90 \%$ share and Uzbekneftegaz a 10\% share. Output was $2.66 \mathrm{bcm}$ in 2010 and is projected to rise to $4 \mathrm{bcm} /$ year from 2012; plateau production is projected at $3 \mathrm{bcm} /$ year from KhauzakShady and $8 \mathrm{bcm}$ from Kandym. Gas from the project is currently processed at the Mubarek processing plant, but Lukoil plans to build its own processing plant at Kandym, to be commissioned in 2016. In March 2012, a consortium led by the Asian Development Bank and Islamic Development Bank provided a $\$ 500$ million loan to Lukoil, thought to be the largest such deal ever for any privately-owned foreign company in Uzbekistan, to finance field development; the ADB has expressed interest in financing the processing plant too. ${ }^{68}$

\footnotetext{
${ }^{63}$ Uzbekneftegaz web site, "Uzbekistan narashchivaet pererabotku gaza"

$<$ http://www.ung.uz/ru/press_center/smi/energet/>; “Aktual'nye tendentsii razvitiia neftegazovoi otrasli Uzbekistana”, Uzbekskii zhurnal nefti i gaza, May 2010

${ }^{64}$ Presentation by Sherzod Akhudjanov, Neftegazinvest, at the Oil Gas Uzbekistan conference (OGU), May 2012, Tashkent

${ }^{65}$ Neftegazexpert, op. cit; Uzinform, “UNG planiruet uvelichit' dobychu i eksport gaza”, 26 December 2011, $<$ http://www.uzinform.com/ru/news/20111226/10666.html>

${ }^{66}$ Oilcapital.ru, “UNG rekonstruiruet DKS na Shurtanneftegaze za \$48m”, 19 September 2011, $<$ http://www.oilcapital.ru/industry/35587.html>

67 "Aktual'nye tendentsii razvitiia neftegazovoi otrasli Uzbekistana”, Uzbekskii zhurnal nefti i gaza, May 2010; gazeta.uz, "Na Gazli dobavili gaza", 30 December 2008 < http://www.gazeta.uz/2008/12/30/gazli>; Zonaks, Kazakhstan, "Uzbekneftegaz do 2015 g. rekonstruiruet podzemnoe khranilishche”, 22 August 2011 $<$ http://www.zonakz.net/articles/36557>

${ }^{68}$ Lukoil Overseas Holding, Corporate Report 2010, p. 35; "Lukoil boosts Uzbek output", Platt's International Gas Report, 4 July 2011; Lukoil press release, "Lukoil privlek krupnyi kredit”, 30 March 2012.
} 
Uzbekneftegaz operates two projects in Bukhara-Khiva together with Gazprom subsidiaries: Kokdumalak and Gissarneftegaz. Kokdumalak is an oil and gas field, which in 2010 produced $6 \mathrm{bcm}$ of associated gas in total (i.e. including a considerable proportion that was reinjected). Kokdumalak is operated by a joint venture, Kokdumalakgaz, set up in 2004 on a parity basis between Zeromax and Mubarekneftegaz, an Uzbekneftegaz subsidiary; since about 2006 there has been participation by Gazprom subsidiaries; now, 25\% of Kokdumalakgaz is owned by GPD, a 50\% Gazprom Germania subsidiary, and some or all of the rest by Mubarekneftegaz. There are considerable technical challenges at the field due to the presence of over-pressured salt water aquifers, some of which were overcome by CNPC, which worked there on a service contract. CNPC states that more than 100 wells had been discarded because of the high-pressure salt water problem, but that in 2006 its engineers successfully completed six wells through the layers, including one with the longest horizontal interval in the Uzbek upstream. ${ }^{69}$ The second area worked with Gazprom participation is Gissar, a group of gas condensate fields including North Nishan and North Guzar. These are operated by Gissarneftegaz, a joint venture formed on a parity basis between Zeromax and Shurtanneftegaz, an Uzbekneftegaz subsidiary; subsequently Zeromax's share passed to Gazprom subisidiaries; now, GPD has a 40\% share. In 2010, the project produced $4.1 \mathrm{bcm}$ of gas, plus 105,600 tonnes of crude oil and 234,800 tonnes of condensate, that were processed in Uzbekistan and exported. ${ }^{70}$

\section{Ustiurt region}

Small volumes of gas are produced from two projects in the Ustiurt region of western Uzbekistan, Shakhpakhty and Urga-Kuanysh. Transport infrastructure links these fields to the Central Asia-Centre pipeline system via which gas is exported to and through Russia. The Shakhpakhty project is operated under a PSA, in which shares are held by Uzbekneftegaz, GPD and Gazpromzarubezhneftegaz; in 2010 it produced $0.2 \mathrm{bcm}$ and peak annual production is expected to be $0.5 \mathrm{bcm}$. The Urga-Kuanysh project covers the Urga, Kuanysh, Dal, Garbii Borsakel'mas, Karachalak, Kokchalak and Akchalak fields. Prospecting was undertaken by Gazprom and Uzbekneftegaz under an agreement signed in 2006 but Gazprom abandoned the project soon afterwards. A 35-year PSA was signed with Petronas in May 2008, covering the same territory; in 2012 small volumes of gas $(0.2 \mathrm{bcm} /$ year $)$ were being produced and sold to Gazprom. ${ }^{71}$

The other significant project in western Uzbekistan is the exploration of a $12,000 \mathrm{sq} \mathrm{km}$ area of the Aral Sea, mentioned above. This is being conducted by a consortium of Lukoil Overseas, Korea National Oil Company, Petronas and CNPC, under a PSA signed in 2006. There are no firm estimates of resources, but they are thought to be up to $1 \mathrm{tcm}$ of gas and 150 million tonnes of oil. In 2010, high-yield gas flow was obtained from a test at the first exploration well, CNPC stated. ${ }^{72}$

\footnotetext{
${ }^{69}$ Gazprom Germania Management Report for 2010, p. 16; CNPC web site, "Uzbekistan" page $<$ http://www.cnpc.com.cn/en/cnpcworldwide/uzbekistan/Uzbekistan.htm\#>

${ }^{70}$ Gazprom Germania Management Report, op. cit.; Zhukov (2009) p. 377.

${ }^{71}$ Uzbekistan Investment Guide, "Petronas has signed its second PSA in Uzbekistan", 14 June 2010, citing Gazeta.uz.

${ }^{72}$ CNPC web site, "Uzbekistan” page
} 
There are three other gas projects being developed with participation by foreign partners: South West Gissar (Lukoil), and Baisunsky and Surkhansky (Petronas). (A fourth project, Mingbulak (CNPC), in the Ferghana region, is an oil project with no reported prospects of associated gas output.)

South-West Gissar, in the South-West Gissar region south-east of Bukhara-Khiva, is being developed by Lukoil Overseas under a 36-year PSA from April 2007. There are seven fields in total - Dzharkudak-Iangi Kyzylcha, Gumbulak, Amanata, Pachkamar and Adamtash (all gas condensate), Iuzhnyi Kyzylbairak (oil-gas condensate) and Koshkuduk (oil). Planned output is $1.1 \mathrm{bcm} /$ year at the first stage, and $5.8 \mathrm{bcm} /$ year at peak. In December 2011 Lukoil reported that the first gas had been produced from Dzharkudak-Iangi Kyzylcha, the largest block. $^{73}$

The Baisunsky and Surkhansky projects are based in the Surkhandarya region of south-east Uzbekistan, between South-West Gissar and the Tajik border. The Baisunsky project is being developed under a 35-year PSA signed with Petronas in June 2010; Petronas has undertaken seismic surveys and well testing in the Gadzhak field, the largest in the project area. The presidential decree approving the project provides for Delta Oil of Saudi Arabia to work in the area. ${ }^{74}$ Petronas has also signed a memorandum with Uzbekneftegaz in 2008, and a shortterm exploration agreement some time afterwards, under which it is conducting exploration at five fields in the Surkhansky area.

\subsection{Kazakhstan}

More than $72 \%$ of the gas that reaches the surface in Kazakhstan's hydrocarbon fields is associated with oil; $28 \%$ is non-associated natural gas. Most of the associated gas is reinjected to support the pressure in oil deposits and enhance oil output; some is flared. The remainder is contributed to Kazakhstan's gas balance, and accounts for a greater share than non-associated natural gas. (There is also blast furnace gas and coke oven gas from steel plants. ${ }^{75}$ Associated and non-associated natural gas produced by oil companies completely dominates the gas production profile. In recent years more than four-fifths of the total sales gas produced has come from the two largest oil fields - Tengiz, operated by the Tengizchevroil joint venture, and Karachaganak, operated by the Karachaganak Petroleum Operating company (KPO). A third large oilfield, Kashagan, is expected to start production in 2013, and will also contribute associated gas to the balance. In addition to these three large fields, there are a swathe of onshore oil and gas deposits in western and southern Kazakhstan, many of which are being produced by subsidiaries of Kazmunaigaz, the national oil and gas company, or of CNPC, or joint ventures, including some that bring together those two companies.

In the past it has been difficult to build up a meaningful statistical picture of Kazakh gas production because the relevant government agencies have only reported total gas production prior to reinjection and flaring, rather than volumes of sales gas. Statistics for sales gas

\footnotetext{
73 “First Uzbek Gissar gas for Lukoil”, Platt's International Gas Report, 16 January 2012, pp 16-17

${ }^{74}$ Postanovlenie Prezidenta respubliki Uzbekistan, 8 June 2010, no. PP-1351; Uzbekistan Investment Guide, "Petronas has signed its second PSA in Uzbekistan", 14 June 2010

${ }^{75}$ By energy content, 2009, extrapolated from Stalistical Agency of the Kazakh republic, Toplivnoenergeticheski balans respubliki Kazakhstan. See also Pirani, Elusive Potential: Gas Consumption in the CIS (Oxford: OIES, 2011), p. 106
} 
volumes have been available only inconsistently. In the last two years the situation has improved, as the two largest producing companies, Tengizchevroil and KPO, have begun to report volumes of dry gas remaining after reinjection, flaring and some liquids production. Using this information, other information made available by government agencies and Kazmunaigaz, and estimates to fill in the gaps, it is possible to present a statistical picture of production in Table 10.

The data released by Tengizchevroil and KPO are shown in the columns for 2009-11 for those companies. Tengizchevroil reports volumes of dry sales gas; for Karachaganak, the figures shown are the sum of:

(i) dry gas delivered to the Orenburg gas processing plant, just across the Russian border, where it is further processed and then either returned to Kazakhstan to supply customers, or delivered to export markets (and no details are available about the volumes of sales gas postprocessing, which are presumably slightly lower than those delivered to Orenburg); and

(ii) a much smaller quantity of gas $(0.6-0.8 \mathrm{bcm} / \mathrm{year}$ in recent years) that is scrubbed at the field and either used there as fuel or delivered to local customers. Tengizchevroil's and KPO's sales/delivered volumes for earlier years, and other companies' sales gas, have been estimated.

The estimates given for total sales gas are conservative: they include

(i) the sales gas from Tengiz and Karachaganak (using the pre-processing volumes of Karachaganak gas that are published, and ignoring the reduction of volume caused by processing at Orenburg);

(ii) estimates of sales gas from Kazmunaigaz's and CNPC's fields that assume that half of it is reinjected or flared; and

(iii) estimates of CNPC-Aktobemunaigaz's sales gas based on levels of consumption in Aktobe region, where it is the main source of supply.

No other gas is counted, although in fact e.g. there are a number of small producing companies that sell gas to Kaztransgaz. Therefore while these estimates for total sales gas may be higher than the actual volumes, it is extremely unlikely that they are lower. ${ }^{76}$

\footnotetext{
${ }^{76}$ The Kazakh statistical agency also publishes energy balances that give a figure for the gas balance that includes a row for gas produced (after reinjection and flaring). However it is impossible to reconcile this number with information given by companies on production. In 2006, 2007, 2008 and 2009 it was $9.6 \mathrm{bcm}, 9.8 \mathrm{bcm}$, $11.7 \mathrm{bcm}$ and $10.9 \mathrm{bcm}$ respectively, i.e. significantly lower than the aggregate total of gas produced from Karachaganak and Tengiz, even without taking all other companies into account. The most likely explanation is that the statistical agency excludes from the gas balance some or all of the gas produced at Karachaganak, processed at Orenburg and sent for export. See Agenstvo respubliki Kazakhstan po statistike, Toplivnoenergeticheskii balans respubliki Kazakhstan 2009 (Astana, 2010), p. 39.
} 
Table 10: Kazakhstan Natural Gas Production (bcm)

\begin{tabular}{|c|c|c|c|c|c|c|}
\hline & 2006 & 2007 & 2008 & 2009 & 2010 & 2011 \\
\hline Total prior to reinjection/flaring & 27 & 29.6 & 33 & 36 & 37.26 & 39.5 \\
\hline Total sales gas (estimated) & 12.8 & 14.2 & 15.9 & 18.3 & 18.6 & 18.5 \\
\hline Kazmunaigaz E\&P & 1.181 & 1.098 & 1.018 & 0.932 & 0.89 & $n / a$ \\
\hline Kazgermunai (KMG 50\% share) & 0.118 & 0.276 & 0.262 & 0.26 & 0.258 & $n / a$ \\
\hline Kazakhoil-Aktobe & 0.224 & 0.14 & 0.107 & 0.136 & 0.141 & $n / a$ \\
\hline Mangistaumunaigaz (KMG 50\% share) & 0 & 0 & 0 & 0 & 0.227 & $n / a$ \\
\hline Other $K M G$ & 0.319 & 0.573 & 0.601 & 0.666 & 0.672 & $n / a$ \\
\hline Amangeldy (Kaztransgaz) & 0.28 & 0.28 & 0.338 & 0.354 & 0.344 & $n / a$ \\
\hline $\begin{array}{l}\text { KMG and affiliates: prior to } \\
\text { reinjection/flaring }\end{array}$ & 2.122 & 2.367 & 2.326 & 2.348 & 2.532 & 2.5 \\
\hline $\begin{array}{l}\text { KMG and affiliates: sales gas - } \\
\text { estimate }\end{array}$ & 1.0 & 1.2 & 1.2 & 1.2 & 1.2 & 1.2 \\
\hline $\begin{array}{l}\text { CNPC-Aktobemunaigaz: prior to } \\
\text { reinj'n/flaring }\end{array}$ & 2.95 & 2.97 & 3.0 & 3.1 & 3.0 & 3.4 \\
\hline $\begin{array}{l}\text { CNPC-Aktobemunaigaz "utilised" (i.e. } \\
\text { not flared) }\end{array}$ & & & & & 2.6 & 3.2 \\
\hline $\begin{array}{l}\text { CNPC-Aktobemunaigaz sales gas - } \\
\text { est. }\end{array}$ & 0.8 & 1.0 & 1.2 & 1.2 & 1.7 & 1.7 \\
\hline Petrokazakhstan (67\% CNPC) & & & & & 0.26 & $n / a$ \\
\hline KuatAmnlonMubai (50\% CNPC) & & & & & 0.17 & $n / a$ \\
\hline CNPC other sales gas - estimate & & & & & 0.1 & 0.1 \\
\hline Tengiz: prior to reinjection/flaring & 6.91 & 7.254 & 8.977 & 11.691 & 13.62 & 13 \\
\hline Tengiz dry gas sold & 3.5 & 4.0 & 5.0 & 7.0 & 7.1 & 6.9 \\
\hline $\begin{array}{l}\text { Karachaganak: est. total prior to } \\
\text { reinj'n/flaring }\end{array}$ & & 11.9 & & 15.541 & 14.988 & 16.854 \\
\hline Karachaganak: reinjected & & & & 6.589 & 6.437 & 8.129 \\
\hline $\begin{array}{l}\text { Karachaganak dry gas - (sum of "dry } \\
\text { gas to Orenburg" and "processed gas } \\
\text { for fuel/sales") }\end{array}$ & 7.5 & 8.0 & 8.5 & 8.952 & 8.551 & 8.725 \\
\hline Other prior to reinjection/flaring & & & & 3.3 & 2.7 & 3.7 \\
\hline
\end{tabular}

Sources:

National total. Prior to reinjection/flaring: 2006-09, Kazakhstan v tsifrakh p. 17; 2010-11, ministry of oil and gas web site. Sales gas: author's estimates.

Kazmunaigaz affiliates. Prior to r/f: Kazmunaigaz annual report 2010, pp. 22-23. Sales gas: author's estimates.

CNPC companies. Prior to r/f: CNPC-Aktobemunaigaz web site, Bernstein, The Caspian: Cradle of Oil

Production, p. 28. Sales gas: author's estimates.

Tengizchevroil. Prior to r/f: Kazmunaigaz annual report 2010, p. 23. Sales gas: up to 2008, author's estimates; from 2009, company reports.

Karachaganak. Prior to r/f: 2007, Yenikeyeff, “Kazakhstan's gas sector”, p. 326; from 2009, extrapolated from company reports (sum of dry gas to Orenburg, processed gas for fuel/sales, and volumes reinjected). Sales gas: up to 2008, author's estimates. From 2009, from company reports.

Other prior to $\mathbf{r} / \mathbf{f}$ : residual estimates

In addition to reinjection, volumes of gas are flared at all Kazakh producing fields, although the level of flaring is a matter of dispute between government, companies, and Global Gas Flaring Reduction (GGFR), the international partnership launched by the World Bank to monitor and reduce flaring, in which Kazakhstan participates. Estimates by GGFR, based on 
satellite data and generally regarded as the most accurate, are that $3.8 \mathrm{bcm}$ was flared in 2010 and $4.7 \mathrm{bcm}$ in 2011 (making Kazakhstan the seventh-largest flarer in the world); for 2008, GGFR's estimate was $5.4 \mathrm{bcm}$, while figures reported by KPO implied a national total of 6.8 bcm flared. The oil and gas ministry states that $1.35 \mathrm{bcm}$ were flared in 2010 and $1.2 \mathrm{bcm}$ in 2011. ${ }^{77}$ Both Kazakhstan's largest oil projects have substantially reduced flaring in recent years. Tengizchevroil reports that flaring has fallen from around 1.8 million tonnes per year in the late 1990s to less than 200,000 tonnes in 2010; in that year the Gas Utilisation Project was completed and routine flaring ceased. KPO reported that flaring had been reduced to very low levels $(0.13 \%$ of all gas produced in $2010,0.08 \%$ in 2011$) .^{78}$

\footnotetext{
${ }^{77}$ Ministry of oil and gas web site, "Itogi deiatel'nosti neftegazovoi otrasli za 2011 god"; GGFR web site, "Estimated flared volumes from satellite data, 2007-2011"; KPO, Otchet ob ustoichivom razvitii za 2009 god, p. 17 , which states that KPO's own flared volume of 33 million cubic metres was $0.48 \%$ of the national total.

${ }^{78} \mathrm{KPO}$, Otchet ob ustoichivom razvitii za 2010 god, p. 2; Otchet ob ustoichivom razvitii za 2011 god, p. 12.
} 


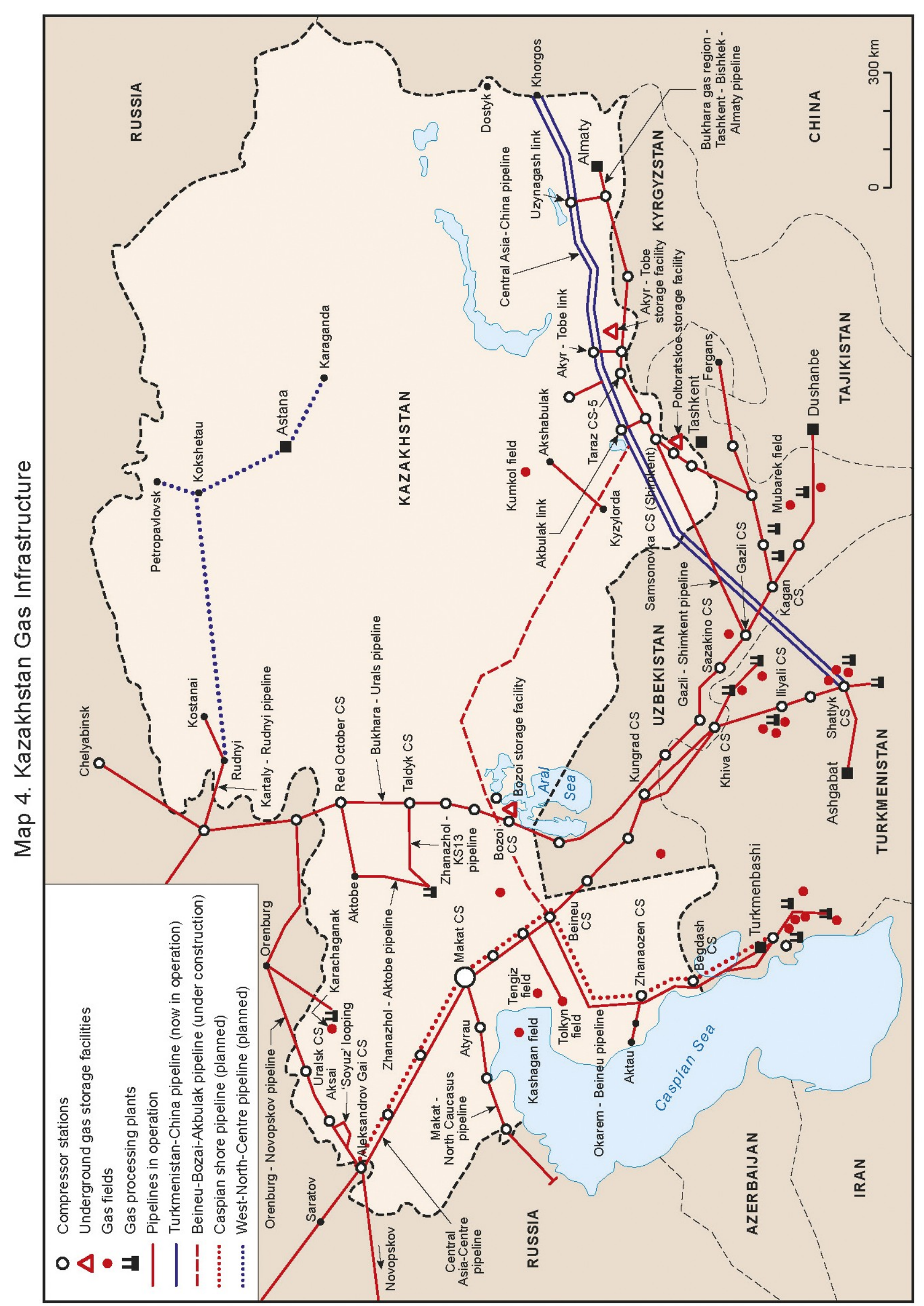




\section{Historical and political context}

Kazakhstan, unlike Uzbekistan and Turkmenistan, is primarily an oil producer. For the government and all those concerned with the Kazakh economy as a whole, gas is third in importance among fossil fuels after oil, Kazakhstan's main export commodity, and coal, the main fuel for Kazakhstan's power and heat sector, as discussed in section 2 above. So while Kazakhstan has since Soviet times exported some gas to and through Russia, and like Uzbekistan has expressed hope of exporting gas to China, these exports are less important to the economy and the government than they are in other Central Asian countries.

Kazakhstan's huge geographical size, and its position, also impact on its role as a gas exporter. Although Kazakhstan is slightly nearer to Russian, European and Chinese markets than Turkmenistan and Uzbekistan, it shares with these two countries the problem that the export infrastructure built in Soviet times takes gas to or through Russia. As market relationships increasingly come to dominate the gas sector, Central Asian exports will struggle to compete with Russian-produced gas - and opening up alternative export routes is difficult and expensive. Kazakhstan has cooperated with its Central Asian neighbours to complete the main export diversification route, to China - but, since gas is far less important an export than oil, it has had little or no reason to pursue diversification strategies apart from this. Secondly, because of its size and because of the availability of coal, especially in the north-east, Kazakhstan is behind the other Central Asian states in making gas available to its own population. Out of 14 administrative regions (oblasts), five have no gas transport infrastructure at all and three of the most heavily populated, in the south-east, rely on imports from Uzbekistan. Even in western Kazakhstan, where oil and gas production is concentrated, gas supply infrastructure is in need of great improvement.

The Kazakh government has viewed gasification as an important aspect of its social policy, and in recent years - no doubt with the social discontent, mentioned in section 2 above, in mind - has given it increasing priority. President Nazarbayev has frequently referred to the importance of gasification in keynote speeches: for example in an address to parliament in September 2012, he referred to the importance of associated gas utilisation, and called for the construction of gas-fired power capacity in western Kazakhstan to be supplied by it (although there is some doubt as to the efficacy of that particular proposal). ${ }^{79}$ The policy objective is to raise domestic gas consumption from around $6-10 \mathrm{bcm} /$ year in recent years to $24 \mathrm{bcm}$ in 2020. (The gasification campaign is discussed in more detail in section 4.3 , below.) Whether or not this policy objective is modified, and whether or not gasification is implemented on this scale, there is little doubt that domestic consumption will rise. So, in addition to existing exports to Russia and existing local consumption, there are two likely sources of incremental demand that will provide the impetus for increased production in the coming years: growth in the local market, and possible shipments to China. This is the background to the government's adoption of a strategic plan for 2011-16 that envisages raising total output of sales gas from $21.3 \mathrm{bcm}$ in 2010 to $30.7 \mathrm{bcm}$ by 2016, on the basis of gas output (prior to reinjection and flaring) of $55.8 \mathrm{bcm}$. The challenges in doing so include not only improving the rate of recovery of associated gas from oilfields, but also raising the gas processing capacity, which was reported in 2012 as $20.6 \mathrm{bcm} /$ year, i.e. slightly above the current total volume of sales gas produced. ${ }^{80}$

\footnotetext{
79 “Elektricheskii koloss na gazovykh nogakh”, Kursiv, 6 September 2012

80 “Kazakhstan planiruet uvelichit' dobychu gaza”, Interfax-Kazakhstan, 16 March 2011; “Elektricheskii koloss na gazovykh nogakh", Kursiv, 6 September 2012
} 
In Kazakhstan, in contrast to Uzbekistan and Turkmenistan, the decisions about how gas will be produced to meet demand, investment priorities, etc, are to a large extent subordinated to decisions about oil production. Decisions about both oil and gas production have for many years been the subject of tough negotiations between Kazakhstan and the IOCs, both western and Chinese, who account for most oil and gas production. The story of this relationship has been told elsewhere, ${ }^{81}$ but one aspect of it is relevant: the government's consistent efforts to raise the proportion of sales gas made available from the big projects and to compel the IOCs to invest in gas infrastructure.

In a series of negotiations with IOCs, in 2008-12 about the largest development project, Kashagan, and in 2009-11 about investment in Kazakhstan's largest producing field, Karachaganak, the government has pressed not only for participation by the national oil company, Kazmunaigaz, but also for greater investment in gas production and processing for the local market. With respect to smaller fields - including the Zhanazhol field operated by CNPC-Aktobemunaigaz, and the Akshabulak field operated by the Kazgermunai joint venture between CNPC and Kazmunaigaz - the government has sought administratively to encourage IOCs to support gas infrastructure projects. The largest and most significant gas infrastructure project in which the government has sought, and received, commitments of IOC participation, is the pipeline under construction between Beineu and Shimkent, scheduled for completion in 2016. This will not only be able to transport gas from western Kazakh fields to the Central Asia-China pipeline, but will also serve local areas en route, boosting the gasification campaign and providing a means of supplying those areas with Kazakh, rather than Uzbek, gas. But there is friction between the government's domestic priorities and the Chinese investors' focus on exports, and in mid 2012 it was reported that the project is being delayed as a result. (See section 5.2.)

The final noteworthy aspect of the government's drive to raise the level of gas available for the local market is the new gas law, which took effect in early 2012, and requires sale of associated gas volumes to Kazmunaigaz affiliates at closely regulated prices. The law establishes a pre-emptive right of the state to purchase gas disposed of by subsoil users and owned by them under the subsoil law and subsoil use contracts (excluding gas from gas fields and imported gas); that this right shall be exercised by a national operator; and that prices shall cover recovery and transportation costs and be approved by the ministry of oil and gas. As expected, in July 2012 Kaztransgaz was appointed national gas supply operator under the new law. ${ }^{82}$ IOCs working in Kazakhstan have lobbied, to date with little success, for more flexible rules on the sale of associated gas volumes to the operator; two lawyers at a leading commercial law firm in Kazakhstan have commented that the law negatively affects the investment climate, since it introduces rather strict regulation of gas sales, transportation and other aspects of the market. ${ }^{83}$ The purchase prices currently paid by Kaztransgaz for associated gas from the major projects are not published, but gas produced by Tethys Petroleum from its Kyzyloi and Akkulka field in the Aktobe region has since 2010 been sold to Asia Gas for $\$ 38 / \mathrm{mcm}$, only slightly higher than the price paid in $2006-10$ of $\$ 32 / \mathrm{mcm}^{84}$

\footnotetext{
${ }^{81}$ See, for example, Ostrowski (2010). A journalistic account, which also covers Azerbaijan, is LeVine (2007)

${ }^{82}$ Zakon respubliki Kazakhstan "O gaze i gazosnabzhenii” (law no. 532-IV signed by the president on 9 January 2012); Ivest.kz, “Kaztransgaz stal natsional'nym operatorom”, 11 July 2012 $<$ http://news.ivest.kz/15754722>.

${ }^{83}$ Maksim Burak and Daria Saginova, "Novyi zakon Respubliki Kazakhstan 'O gaze i gazosnabzhenii'”, 23 January $2012<\mathrm{http}: / /$ www.gratanet.com/ru/publications/457>

${ }^{84}$ Tethys Petroleum, Introduction to the Official List (for trading on the London Stock Exchange), 2011, pp. $101-102$
} 
and well below the regulated wholesale prices paid by gas consumers. At the time of writing much detail about how the law's provisions will be implemented is unclear.

The remainder of this section describes production and development prospects by field.

\section{Production: the large oil projects}

Karachaganak is Kazakhstan's largest gas producer, with output of 8.5-9 bcm/year of dry gas in recent years, which is purchased at the field by Kazrosgaz, the Gazprom-Kazmunaigaz joint venture. More than $90 \%$ of this gas is delivered to the Orenburg gas processing plant in Russia, and then either returned to Kazakhstan to supply local customers, or sent to export destinations.

Karachaganak, which produces nearly one-fifth of Kazakhstan's oil production and substantial volumes of gas condensate, as well as gas, is operated by KPO under a 40-year concession that began in January 1998. ${ }^{85}$ In December 2011 Kazmunaigaz took a $10 \%$ stake in the project, in exchange for a payment to the other partners of $\$ 3$ billion; shares are now held by the two joint operators, ENI (29.25\%) and BG Group (29.25\%), and by Chevron $(18 \%)$, Lukoil (13.5\%) and Kazmunaigaz (10\%). The agreement under which Kazmunaigaz entered the project brought to an end two years of mounting friction between the government and the consortium, which had been accused of licence breaches, unlawful use of foreign workers, incorrect tax payments, and other alleged offences. In 2010 the sides went to international arbitration over accusations that the consortium had overstated costs. Under the December 2011 agreement both sides dropped all claims against each other. ${ }^{86}$

At Karachaganak, two development phases, out of four planned, have been completed. Negotiations over phase three, on which the future level of gas output will depend, have not been concluded. There are two claims on phase three gas from Karachaganak: for an extra 7$8 \mathrm{bcm} /$ year to Orenburg, to raise volumes sent there to $16 \mathrm{bcm} /$ year, and for $5 \mathrm{bcm} /$ year to supply a new gas processing plant at Karachaganak itself, proposed by the Kazakh government. The extra volumes for Orenburg were agreed upon in principle in October 2006, between the Russian and Kazakh governments. They agreed to establish a joint venture to operate the Orenburg plant, as and when the Karachaganak phase three development began. The Soviet-era infrastructure that links Karachaganak to Orenburg has $20 \mathrm{bcm} / \mathrm{year}$ of capacity, so there are no constraints. But in 2009, the two sides agreed to put this plan on ice, since the stalled negotiations between the consortium and the Kazakh government had delayed the start of Karachaganak's phase three. ${ }^{87}$ Since then, demand projections for both the Russian and European markets have been severely reduced, and it is unclear whether or how these proposals could be revised.

The proposal to build a $5 \mathrm{bcm} /$ year gas processing plant at Karachaganak is part of the government's gasification drive, and was highlighted by president Nazarbayev in a speech in February 2012. At public hearings in the West Kazakhstan region on the future development of Karachaganak, both oil minister Sauat Mynbayev and representatives of Kazrosgaz pressed for the consortium to take the gas processing plant into account. Kazmunaigaz has stated that in keeping with the gasification drive, construction of the plant should be

\footnotetext{
${ }^{85}$ For the earlier history of the project and other details, see Yenikeyeff (2009), pp. 325-326.

${ }^{86}$ Isabel Gorst, "Oil group secures Kazakh agreement”, Financial Times, 14 December 2011; "State takes

Karachaganak stake”, International Gas Report, 19 December 2011

${ }^{87}$ Kazmunaigaz, Godovoi Otchet 2010, p. 30
} 
undertaken in 2014-18, and that the plant could be included in the consortium's phase three, or financed separately as a joint venture or by the state. ${ }^{88}$ Whether and how quickly gas output will be raised from Karachaganak to meet this and other possible demand will be resolved in the course of the negotiations on the third phase.

Kashagan, the largest Caspian offshore oil and gas field, has estimated recoverable resources of 7-9 billion barrels of oil and $490 \mathrm{bcm}$ of proven gas reserves, and is due to start commercial production in mid 2013. It should easily overtake Karachaganak as Kazakhstan's largest producer of gas at some point thereafter. The field is projected to be developed in two main stages: the experimental programme (2013-18), during which commercial production will start, the reservoir will be assessed, and production brought to around 400,000 barrels/day of oil and $10.5 \mathrm{bcm} /$ year of gas - of which $55 \%$ will be reinjected, leaving around $4.8 \mathrm{bcm}$ of sales gas. During further phases of development, oil production could reach 1.5 million barrels/day, although, due to planned reinjection, gas output may not rise substantially. The volume of gas reinjection during the further phases of development has not been finalised, however.

The start-up of production at Kashagan, originally scheduled for 2005, has been repeatedly delayed, partly because of the considerable technical difficulties presented by offshore development in shallow but seasonally ice-covered water, the levels of hydrogen sulphide in the hydrocarbons, the lack of infrastructure, etc. There have been a series of disputes between the Kazakh government and the IOCs that work at the field, the most recent chapter of which started in 2007, when Eni, then the operator, announced a sharp increase in the projected budget (from $\$ 57$ billion to $\$ 136$ billion), and the most recent postponement of production. The government suspended the project and threatened to annul the licence. ${ }^{89}$ The outcome was that the government insisted that Eni be replaced by joint operatorship. In 2008, Kazmunaigaz doubled its stake in the project, and joint operatorship was agreed. (From that point the consortium consisted of Kazmunaingaz, ExxonMobil, Shell, Total, Eni (with $16.81 \%$ each), Conoco Phillips (8.39\%) and Inpex of Japan (7.56\%).

Disagreements between the consortium and the government over costs erupted again in 2011, however. Reportedly, alternative scenarios prepared by Shell's Kashagan Cost Reduction Team were presented to the oil and gas ministry, and the other partners, in December that year, but not agreed. In February 2012 work was wound down on the second phase of development, as disagreements persisted. In May a new agreement was signed, with the foreign partners agreeing to pay $\$ 986$ million to fund the state's contribution to development costs for $2012-13 . .^{90}$

Within the larger dispute about costs, the government and IOCs were also negotiating over the field's future gas output. In 2008, one of the changes made to the development plan by Eni was to scrap proposals to install gas processing capacity in Atyrau, and to raise the proportion of gas to be reinjected. This was opposed by the government. In 2012, as part of the agreement on costs signed in May, the foreign partner companies conceded that from the start-up of commercial hydrocarbons production, gas will be purchased by KazTransGas for

\footnotetext{
${ }^{88}$ Kazrosgaz press release, "Construction of a new gas processing plant at Karachaganak", 7 February 2012;

“Gas Refinery Planned for BG, Eni-Led Field”, 10 February 2012, Bloomberg News; “Pervuiu ochered' GPZ na Karachaganake vvedut v ekspluatatsiiu v 2019 godu”, Tengri News, 10 Feburary 2012

$<$ http://tengrinews.kz/mney/207960/>

${ }^{89}$ Babali (2009), pp. 1298-1308; Isabel Gorst, "Kashagan: a Caspian dream turned headache for oil majors", Financial Times, 9 June 2011; Richard Orange, "Shell shuts Caspian office”, Daily Telegraph, 24 May 2011

${ }^{90}$ Reuters, "Kazakh oilfield firms to pay $\$ 1$ bn state investment", 28 May 2012
} 
sale on the domestic market. The companies' hopes of achieving export prices for the gas have not been realised, but neither have the government's hopes of the gas being supplied free of charge, as it is from the ACG field in Azerbaijan. ${ }^{91}$

During 2012 there have been reports of further possible changes in the consortium. ExxonMobil was reported to be in talks with ONGC of India about selling part of its stake; more recently, both Shell and ExxonMobil were reported to be seeking greater shares, an extension of the PSA and a new agreement on operatorship; in November 2012, ConocoPhillips announced that it will sell its stake to ONGC. ${ }^{92}$ At the time of writing these issues remain unresolved. Clearly, as with the negotiations over Karachaganak, the decisions about what proportion of the project's gas is sold, and under what terms, will be crucial for the future of Kazakhstan's market and gas production profile.

Tengiz, currently Kazakhstan's second largest source of gas, is operated by Tengizchevroil (a partnership formed in 1993, with current partners Chevron (50\%), Kazmunaigaz (20\%), ExxonMobil Kazakhstan (25\%) and LukArco, a Lukoil-BP joint venture (5\%)). Tengiz began production in 1993 and raised output to $12-15$ million tonnes/year of oil and around 2.5 $\mathrm{bcm} /$ year of gas during the 2000s. The commissioning of the Second Generation Plant in 2008 made possible a further increase in oil output, which reached 25.6 million tonnes in 2011; the volume of dry sales gas (after reinjection) reached about $7 \mathrm{bcm} /$ year $(6.9 \mathrm{bcm}$ in 2011; see Table 10 above). ${ }^{93}$ At the time of writing, the shareholders are in discussion with government about the future development of the project. An increase in oil output to 36 million tonnes/year is projected; according to newspaper reports, some shareholders advocate construction of a third processing complex to achieve this, while Samruk Kazyna, the state holding company that manages the government's share, believes this is unnecessary. ${ }^{94}$ There are also proposals under discussion for a petrochemicals complex supplied by Tengiz production (see section 4.3 below).

\section{Other onshore projects}

Apart from the gas produced at Karachaganak and Tengiz, most of Kazakhstan's gas production is associated gas from onshore oil fields. In the past the gas was mostly flared or reinjected. But the way that it is used is changing, firstly due to government and company policies requiring greater utilisation (i.e. reinjection, use as fuel, or processing for sale, rather than flaring), and secondly, due to local demand, which is increasing, in part due to gasification policies. The situation, by region (oblast), is as follows:

Mangistau, in south-west Kazakhstan, the historical heart of oil production. The largest oil producers are two Kazmunaigaz subsidiaries, Ozenmunaigaz (which produces 5-6 million tonnes/year of oil) and Embamunaigaz (2.8-2.9 million tonnes). Ozenmunaigaz has much greater associated and natural gas resources, which are supplied to a processing plant. Its output is (i) dry gas, some of which is used to supply power to the company's fields, and the remainder of which is supplied to the local market (probably less than $1 \mathrm{bcm} /$ year), and (ii) NGLs. In recent years the market for compressed natural gas (CNG) for transport in the

\footnotetext{
${ }^{91}$ Yenikeyeff (2009), p. 329; Reuters, "Kazakh oilfield firms to pay”, op. cit.

92 Reuters, "Kashagan's big oil coming to market mid 2013”, 10 August 2012; Bloomberg, "Exxon, Shell Said Seeking Control of Kashagan", 30 August 2012

93 Tengizchevroil Annual Report 2011; Tengizchevroil web site; Yenikeyeff (2009), pp. 326-327.

94 “Tengiz popal pod davlenie", Kursiv, 21 June 2012; "Stroitel'stvo novogo zavoda na Tengize otlozheno", Kapital, 23 October 2012
} 
region has risen substantially, and production has risen accordingly. ${ }^{95}$ Reported associated gas production at two other fields in Mangistau, Tolkyn and Borankol, increased during the $2000 \mathrm{~s}$ - from about $0.6 \mathrm{bcm}$ in 2003 to $2.4 \mathrm{bcm}$ in 2009 - until the operating companies, Tolkynneftegaz and Kazpolmunai, had their licences withdrawn by the ministry of oil and gas in July 2010. The construction of a $2.4 \mathrm{bcm} /$ year gas processing plant has been put on hold, Kazmunaigaz stated. (According to press reports, Ascom, a Moldovan-based holding company, has taken a case to the Stockholm arbitration court as a result of the licence withdrawal.) The fields have been put under the temporary management of Kazmunaigaz. ${ }^{96}$

Aktobe. The main oil field in the region, Zhanazhol, is operated by a CNPC subsidiary, CNPC-Aktobemunaigaz (oil production 6.2 million tonnes in 2011). Gas production of 3.4 bcm was reported in 2011, but most of this is used to apply gas-lift technology for oil production (where it is currently used in two-thirds of producing wells), or for reinjection, or for power supply on the field. However CNPC-Aktobemunaigaz is also investing in a gas processing plant that supplies gas to the local market via the $5 \mathrm{bcm} /$ year ZhanazholOktyabrsk-Aktobe pipeline, which runs eastward from the field and connects to the BukharaUrals pipeline. In 2007 the first of three units of the plant, with a capacity reported at 0.7 $\mathrm{bcm} /$ year, was commissioned. Construction of the second unit is due to begin in 2012; when all three are completed the plant will have a capacity of $5 \mathrm{bcm} /$ year. $^{97}$

The Urikhtau field, which borders directly on Zhanazhol, was in 2008 earmarked for development by a Kazakh-Chinese joint venture, under a framework agreement between CNPC and Kazmunaigaz. In May 2011 it was reported that Kazmunaigaz, through its whollyowned subsidiary Urikhtau Operating, had discovered much more substantial reserves at Urikhtau than had been known about before: about 200 million tonnes of oil, in addition to previous reserves of $40 \mathrm{bcm}$ of gas and 11 million tonnes of condensate. This is the first discovery of this scale by a Kazakh company working independently of foreign partners. In May 2012, Kazmunaigaz executives announced plans for the drilling of exploration wells but up to the time of writing, no announcement has been made about the formation of the joint venture. ${ }^{98}$ Industry sources suggest that there is tension between Kazakhstan and China over the issue, that Kazakhstan hopes to limit Chinese involvement in the field, and that this is exacerbating tensions over the construction of the Beineu-Shimkent pipeline (see section 5.2).

\footnotetext{
${ }^{95}$ Kazmunaigaz Annual Report 2011, p. 23; Kazmunaigaz web site, "Utilizatsiia gaza" page $<$ http://www.kmg.kz/ecology/programme/utilization/>

${ }^{96}$ Kazakh ministry of oil and gas press release, "Borankol'skii GPZ perekhodit vo vremennoe upravlenie Kazmunaigaza”, 21 July 2010; Kazmunaigaz press release, "S TOO 'Tolkynneftegaz' rastorgnut kontrakt”, 22 July 2010; Neftegazekspert, "Dosrochno prekrashcheno distvie kontraktov na pravo nedropol'zovaniia", 2 August $2010<$ http://www.neftegazexpert.ru/neftegazline/neftegaztext91024.html>; Kazakhstan Today, "Na mestorozhdeniakh Tolkyn i Borankol"”, 26 January 2004; "Po itogam 2008 goda", Kazenergy no. 2, 2010, p. 65.

${ }^{97}$ CNPC web site, Kazakhstan page < http://www.cnpc.com.cn/NR/exeres/3CAE5E89-8280-4FB3-BB4CC7EBD3811473.htm?NRMODE=Unpublished\&wbc_purpose=Basic\&WBCMODE=PresentationUnpublished $>$ ; Interfax-Kazakhstan, "CNPC-Aktobemunaigaz pristupit k stroitel'stvu II ocheredi Zhanazholskogo TPZ-3”, 25 November 2011; Halyk finance, “CNPC-Aktobemunaigas increased 2011 oil production”, 24 February 2012.

${ }^{98}$ CNPC press release "CNPC and KazMunayGas sign framework agreement", 1 November 2008; Urikhtau Operating web site; "KMG otkryl novoe krupnoe mestorozhdenie nefti", Kursiv, 19 May 2011; "Urikhtau mozhet dostat'sia Kitaiu", Kursiv, 27 May 2011; "Razvedochnye skvazhiny na Urikhtau nachnut burit' cherez dva mesiatsa", Novosti Kazakhstan, 23 May 2012.
} 
The picture of production in Aktobe is completed with Tethys Petroleum, which produces a small quantity of gas from three blocks near the Aral Sea in the south of the region. This is supplied into the Bukhara-Urals pipeline. ${ }^{99}$

Kyzylorda. The two main oil producers in the Kyzylorda region are PetroKazakhstan, which operates fields in the Kumkol area and is owned by CNPC (67\%) and Kazmunaigaz (33\%); and Kazgermunai, which operates fields in the South Turgai area and is owned by PetroKazakhstan (50\%) and Kazmunaigaz (50\%). In 2005 Kazgermunai commissioned a gas treatment plant and began to supply a small quantity of gas (about $0.1 \mathrm{bcm}$ ) to the local market. PetroKazakhstan also has a gas utilisation programme that had by 2009 put an end to flaring at its operations; the gas is used mainly for reinjection and for power generation in the oil fields. ${ }^{100}$

Zhambyl in southern Kazakhstan. The Amangeldy group of fields in Zhambyl have been developed by Kaztransgaz, a Kazmunaigaz subsidiary whose main business is gas transportation and supply. The project has been prioritised by Kazmunaigaz as a means of reducing dependence of south and south-east Kazakhstan on gas imports from Uzbekistan. Production began in 2006, and rose from $0.28 \mathrm{bcm}$ in that year to $0.34 \mathrm{bcm}$ in $2010 .^{101}$

\subsection{Azerbaijan}

Almost all of Azerbaijan's current gas production comes from three offshore projects: the Azeri-Chirag-Guneshli (ACG) oilfield, operated by BP on behalf of an international consortium, from which $4-5 \mathrm{bcm} /$ year of associated gas is brought ashore as sales gas; the Shah Deniz (stage 1) gas project, operated by BP and Statoil on behalf of an international consortium, which produces $6-7 \mathrm{bcm} /$ year and is expected to achieve peak output of 8.9 $\mathrm{bcm} /$ year; and the Guneshli shallow fields, operated by Socar, the national oil and gas company, producing 5-6 bcm/year. This gas is effectively divided between the domestic market and exports to Turkey and Georgia. Small amounts of gas $(2-3 \mathrm{bcm} / \mathrm{year})$ are produced onshore by Socar; these are mostly exported to Russia; to Georgia; and to Iran in return for gas supplied to Nakhchivan, the Azeri enclave south-west of Armenia. The production statistics published by the state statistics agency and Socar are shown in table 11:

\footnotetext{
99 Tethys web site, “Operations/Kazkahstan” page

${ }^{100}$ Kazgermunai web site; PetroKazakhstan corporate brochure, p. 19

${ }^{101}$ Kazmunaigaz Godovoi otchet 2010, pp. 22-23.
} 
Table 11: Azerbaijan Gas Production (bcm)

\begin{tabular}{|l|r|r|r|r|r|r|}
\hline bcm & $\mathbf{2 0 0 6}$ & $\mathbf{2 0 0 7}$ & $\mathbf{2 0 0 8}$ & $\mathbf{2 0 0 9}$ & $\mathbf{2 0 1 0}$ & $\mathbf{2 0 1 1}$ \\
\hline Natural and associated gas (total) & 9.1 & 16.9 & 23.4 & 23.6 & 26.3 & 25.7 \\
\hline Socar (total) & 4.4 & 6.0 & 7.7 & 6.9 & 7.2 & 7.1 \\
\hline Other companies (total) & 4.7 & 10.9 & 15.7 & 16.7 & 19.1 & 18.6 \\
\hline $\begin{array}{l}\text { Natural and associated gas } \\
\text { (reinjected, flared, own use, etc) }\end{array}$ & 3.0 & 6.1 & 7.1 & 7.3 & 9.6 & 9.3 \\
\hline $\begin{array}{l}\text { Natural and associated gas (sales } \\
\text { gas) }\end{array}$ & $\mathbf{6 . 1}$ & $\mathbf{1 0 . 8}$ & $\mathbf{1 6 . 3}$ & $\mathbf{1 6 . 3}$ & $\mathbf{1 6 . 7}$ & $\mathbf{1 6 . 4}$ \\
\hline Associated gas (total) & 6.7 & 9.6 & 12.8 & 12.1 & 12.4 & 13.4 \\
\hline $\begin{array}{l}\text { Associated gas (reinjected and } \\
\text { flared) }\end{array}$ & $\mathrm{n} / \mathrm{a}$ & 5.6 & 0.4 & 6.9 & 7.6 & 9.0 \\
\hline Associated gas (sales gas) & $\mathbf{n} / \mathbf{a}$ & $\mathbf{4 . 0}$ & $\mathbf{1 2 . 4}$ & $\mathbf{5 . 2}$ & $\mathbf{4 . 8}$ & $\mathbf{4 . 4}$ \\
\hline Natural gas (total) & 2.4 & 7.3 & 10.6 & 11.5 & 13.9 & 12.3 \\
\hline $\begin{array}{l}\text { Nat. gas (own use, into storage, } \\
\text { etc) }\end{array}$ & $\mathrm{n} / \mathrm{a}$ & 0.5 & 6.7 & 0.4 & 2.0 & 0.3 \\
\hline Natural gas (sales gas) & $\mathbf{n} / \mathbf{a}$ & $\mathbf{6 . 8}$ & $\mathbf{3 . 9}$ & $\mathbf{1 1 . 1}$ & $\mathbf{1 1 . 9}$ & $\mathbf{1 2 . 0}$ \\
\hline
\end{tabular}

Sources: Energy Balance of Azerbaijan 2011 (AzStat 2011), p. 161; Energy of Azerbaijan 2012 (AzStat 2012), p. 163; Socar web site

Note: there is an unexplained anomaly in 2008, when only a very small volume of associated gas was used for reinjection. The statistics suggest that natural gas was held off the market to make way for the extra volumes that resulted.

\section{Historical and political background}

The government of Azerbaijan set a course towards partnership with IOCs to develop its large oil and gas fields more readily than did the other Caspian and Central Asian producing states. The landmark memorandum with an IOC consortium to develop the ACG field was signed in September 1992, less than a year after the dissolution of the Soviet Union; the PSA was signed in 1994. A PSA covering Azerbaijan's largest gas resource, the Shah Deniz field, was signed in 1996 with a consortium in which the operators were BP, also operator of ACG, and Statoil, a member of the ACG consortium. ${ }^{102}$ Azerbaijan's upstream development over nearly two decades has thus been dominated by three companies - Socar, BP and Statoil working in partnership. The relationship between the government and its international partners, in contrast to those in other producing countries in the region, has been relatively harmonious. A recent indication of tension - the public criticism of BP by president Ilham Aliev in October 2012, on account of lower than expected output at the ACG field ${ }^{103}$ - most likely indicates the concern in Azerbaijan's political leadership about the fiscal, and therefore social and political, consequences of the forthcoming natural decline of oil production, referred to in section 2 above. The close relationship between Azerbaijan and the IOCs could also be tested by differences over the transit and marketing of Shah Deniz II gas, and this in turn could impact the timing and final form of that project. The rest of this section surveys the producing gas resources, and looks at development possibilities.

\footnotetext{
102 Both PSAs are published on BP web sites

${ }^{103}$ Reuters, “Azeri president attacks BP over low oil output”, 11 October 2012; Reuters, "BP reaches agreement with Socar on Azeri output fall", 24 October 2012; "BP, Socar officials meet on ACG production declines", Oil \& Gas Journal, October 2012.
} 
Map 5: Azerbaijan Gas infrastructure

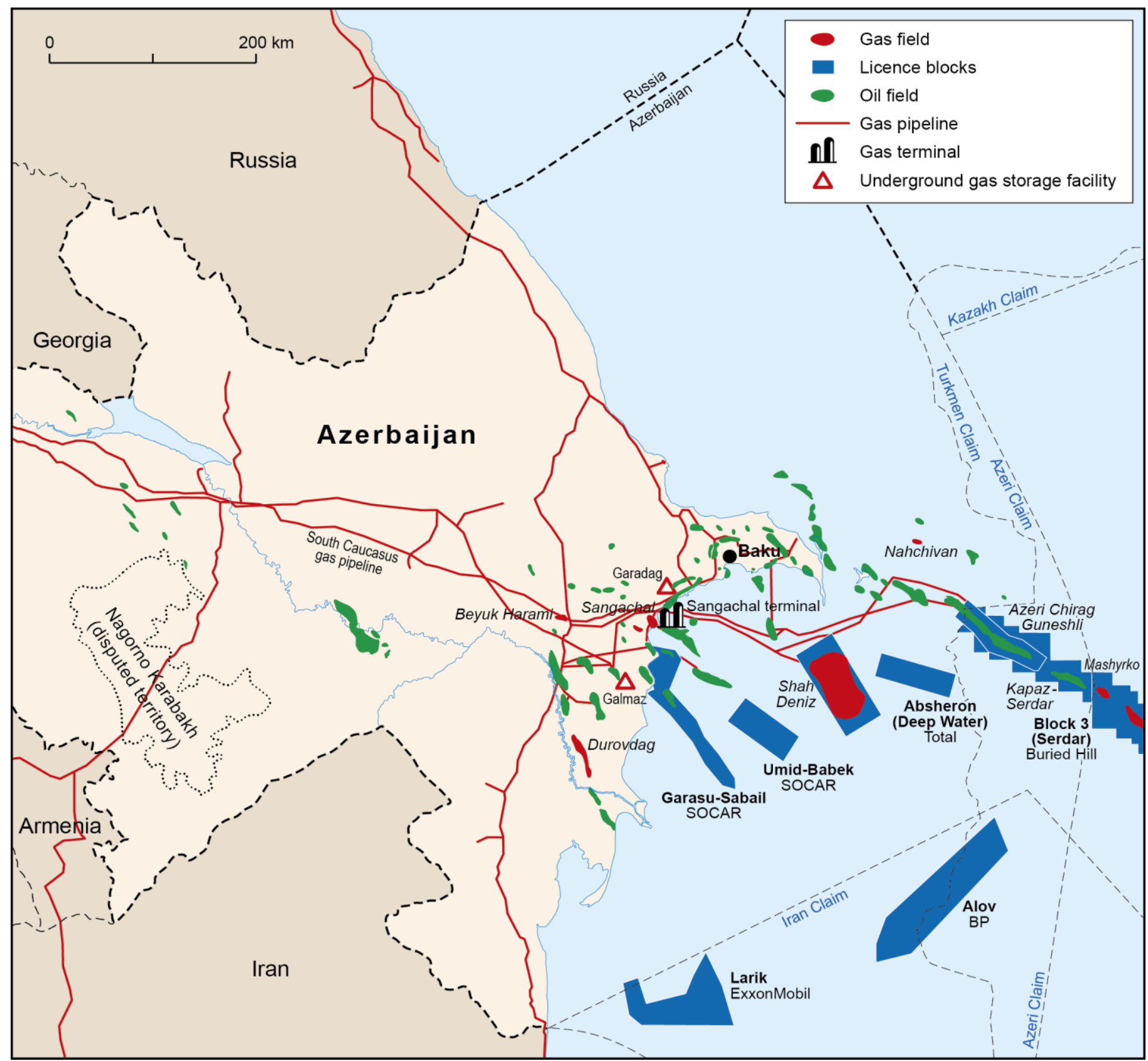

Producing fields

Azeri-Chirag-Gunashli (ACG), Azerbaijan's largest hydrocarbons project, is operated by BP on behalf of the Azerbaijan International Operating Company (AIOC) consortium and Socar. The other participants in the consortium along with BP are Chevron, Statoil, Turkiye Petrolleri, ExxonMobil, Socar, Hess, Inpex and Itochu. ${ }^{104}$ The field, $100 \mathrm{~km}$ east of Baku, was discovered in the early 1980s and production started in 1997. It is covered by a 30 -year production sharing agreement (PSA) signed in 1994. During the early 2000s, four fixed new production platforms were installed offshore and started production, together with a compression and water injection platform; a sixth production platform was sanctioned in March 2010. Oil production is 830,000 bpd (2010), and gas output (prior to reinjection) has

${ }^{104}$ BP web site, “Azerbaijan” page 
risen from $6.7 \mathrm{bcm}$ in 2006 to $12-13 \mathrm{bcm}$ in recent years. ${ }^{105}$ Most of the gas produced is reinjected into the oil reservoirs to increase pressure; the remainder of it is delivered to the Sangachal terminal, offshore south of Baku, for delivery into Azerbaijan's transportation network. Although the volumes of sales gas are not made public by the consortium, they account for the vast majority, if not all, of associated gas delivered for sale in Azerbaijan, as indicated in Table 11, i.e. between $4 \mathrm{bcm}$ and $5.2 \mathrm{bcm}$ in recent years. (There is an unexplained anomaly in the statistics in 2008, when the volume was much larger, perhaps due e.g. to technical problems related to reinjection.) The sales gas is delivered free of charge to Socar, under the terms of the PSA. ${ }^{106}$

The Shah Deniz field is operated by BP and Statoil on behalf of a consortium, comprising BP (25.5\%), Statoil (25.5\%), Total (10\%), Lukoil (10\%), Socar (10\%), OIEC of Iran (10\%), and Turkiye Petrolleri (9\%). (Of these companies, BP, Statoil, Turkiye Petrolleri and Socar also participate in the ACG consortium.) Shah Deniz, $70 \mathrm{~km}$ south east of Baku in water depths of 50-500 metres, is one of the world's largest gas-condensate fields, with more than $1 \mathrm{tcm}$ of gas in place. The stage 1 project began producing gas in 2006; output has risen from $3.1 \mathrm{bcm}$ in 2007, and will peak about $9 \mathrm{bcm} /$ year; its gas is sold on the Azeri domestic market, and exported to Georgia and Turkey (see section 5.5 below). ${ }^{107}$

The shallow water Guneshli fields are operated by Socar. They account for $70 \%$ of Socar's production of gas, i.e. $4-5.5 \mathrm{bcm} /$ year in total (prior to reinjection, own use and flaring) in recent years, as well as about $60 \%$ of its production of oil, i.e. 5.0-5.5 million tonnes/year in recent years. Large amounts of gas were flared or vented, but this has been reduced in recent years: according to the Global Gas Flaring Reduction Initiative, the volumes flared or vented fell from $0.49 \mathrm{bcm}$ in 2007 to $0.276 \mathrm{bcm}$ in 2010 . $^{108}$ In 2011 Socar adopted a development programme for 2011-15 for the field, which set out the means by which production would be maintained at the current level. It provided for the drilling of new wells, and the introduction of gas-lift technology in order to maintain pressure in the oil reservoir. In early 2012, under this programme, a compressor station was installed on the Guneshli-4 platform, comprising two turbines, with an aggregate capacity of 2 million $\mathrm{cu} \mathrm{m} /$ day $(1.4 \mathrm{bcm} / \mathrm{year})$; the pressurised gas will either be reinjected or taken ashore as sales gas. ${ }^{109} \mathrm{~A}$ much smaller quantity of gas (less than $1 \mathrm{bcm} /$ year) is produced by Socar from onshore fields.

Gas produced in Azerbaijan is processed at a dedicated Soviet-era gas processing plant at Garadagh, and at the integrated oil and gas terminal at Sangachal, which was completed in 1997. The Garadagh plant is operated by Socar, and processes gas both from ACG and from Socar's own production. It was first commissioned in 1961, attained a capacity of 4.5 $\mathrm{bcm} /$ year in the $1970 \mathrm{~s}$ and was expanded to a capacity of $6.5 \mathrm{bcm} / \mathrm{year}$ in 1986 . The plant

\footnotetext{
${ }^{105}$ Oil production, Statoil web site,

$<$ http://www.statoil.com/en/About/Worldwide/Azerbaijan/Pages/AzeriChiragGunashli.aspx>; gas production, author's estimate from company information and press reports

${ }^{106}$ Agreement on the Joint Development and Production Sharing for the Azeri and Chirag Fields and the Deep Water Portion of the Gunashli Field in the Azerbaijan Sector of the Caspian Sea, Article 15.1, states that residue Associated Natural Gas (but not non-associated gas) shall be "delivered free of charge to Socar at the delivery point".

${ }^{107}$ BP web site, "BP Caspian: Shah Deniz” page; Bowden (2009), pp. 203-234.

${ }^{108}$ World Bank/GGFR web site, “Azerbaijan: Reducing Associated Petroleum Gas Flaring and Venting”

${ }^{109}$ Socar annual report 2010, p. 29; www.economy.az, "GNKAR utverdila piatiletniuiu programmu”, 4 April $2011<\mathrm{http}$ //www.economy.az/archives/54379>; www.rusenergy.com, "Socar povyshaet effektivnost' sbora gaza", 16 March $2012<$ http://www.rusenergy.com/ru/news/news.php?id=58689>; Interfax Azerbaijan, "Socar postroila gazokompressornuiu stantsiu", 4 May 2012.
} 
was incorporated into Socar in 2007. Azerbaijan's main gas storage facility, with $3.1 \mathrm{bcm}$ of capacity, is also at Garadagh; there is a second facility at Galmaz. The Sangachal terminal is operated by BP and receives gas from both ACG and Shah Deniz. It went into operation in 1997 , and underwent a major expansion starting in $2002 .^{110}$

\section{Shah Deniz II development and other possibilities}

The increase in Azeri gas output in the coming years will be realised in the first place from the second stage of the Shah Deniz project (also named the full field development). At the time of writing Shah Deniz II is in the front-end engineering and design phase, with a final investment decision expected in mid 2013. The project, if it goes ahead as planned, will include the construction of two new platforms and 26 subsea wells with in-field infrastructure; expansion of the Sangachal Terminal and the South Caucasus pipeline, and development of additional export infrastructure. On the current timetable, production would start in late 2017 and peak at $16 \mathrm{bcm} /$ year. ${ }^{11}$

Shah Deniz output, plus current Azeri production from other fields, should provide 28 $\mathrm{bcm} /$ year of sales gas. Azeri hopes of raising output further than that after 2020 rest with a number of discoveries and prospects in the Azeri sector of the Caspian, of which the closest to development is the Absheron field. These are listed in Table 12.

Table 12: Azerbaijan: offshore Caspian projects at pre-development stage

\begin{tabular}{|l|l|l|}
\hline Field & Resources & Companies and agreements \\
\hline Absheron & $\begin{array}{l}150-300 \text { bcm gas, 45 mt } \\
\text { condensate. } \\
\text { Commerciality confirmed July } \\
2012\end{array}$ & $\begin{array}{l}\text { Total (40\%, operator), Socar } \\
(40 \%) \text {, GDF Suez (20\%) }\end{array}$ \\
\hline $\begin{array}{l}\text { Azeri-Chirag-Guneshli } \\
\text { deep layers }\end{array}$ & $\begin{array}{l}200 \mathrm{bcm} \text { gas (preliminary } \\
\text { estimate) }\end{array}$ & $\begin{array}{l}\text { PSA under negotiation with } \\
\text { ACG partners }\end{array}$ \\
\hline Umid & $\begin{array}{l}\text { 200 bcm gas, 40 mt condensate } \\
\text { (preliminary estimate) } \\
\text { Discovered 2010 }\end{array}$ & Socar \\
\hline Nakhchivan (prospect) & $\begin{array}{l}\text { Up to 300 bcm gas (preliminary } \\
\text { estimate) }\end{array}$ & RWE, Socar. MoU signed 2010 \\
\hline Babek (prospect) & $\begin{array}{l}400 \text { bcm gas, 80 mt condensate } \\
\text { (preliminary estimate) }\end{array}$ & Socar \\
\hline $\begin{array}{l}\text { Shafag-Asiman } \\
\text { (prospect) }\end{array}$ & 3D seismic data being processed & BP, Socar. PSA signed 2010 \\
\hline
\end{tabular}

Source: companies' announcements and publications

Commerciality of the Absheron field, $100 \mathrm{~km}$ south-east of Baku, the partners in which are Total EP Absheron (40\%, operator), Socar (40\%) and GDF Suez (20\%), was confirmed in July 2012. In September 2011, the Absheron X-2 well had encountered more than 150 metres of cumulative net gas pays in high quality sands on the north flank of a $270 \mathrm{sq} \mathrm{km}$ structure. Total's geologists were especially pleased with the discovery, because the Absheron field had been explored before, with disappointing results: Chevron had held the licence in 1997-2005

\footnotetext{
${ }^{110}$ Socar web site, "Gas processing plant" page

${ }^{111}$ BP web site, "Shah Deniz" page
} 
but relinquished it. Reprocessing and reconsideration of 3D seismic data, with the aid of more advanced modelling, and the drilling of new wells, had made the difference. ${ }^{112}$

Other resources that may be close to development are the deep gas reservoirs below the ACG fields. The reservoirs, Girmekiustu and Girmekialti, underneath the Fasila layer, are understood to contain substantial gas resources, but the lack of appraisal drilling means that the scale of these is uncertain. There have been long-running discussions between Socar and the ACG consortium members about the terms on which these fields will be developed. Socar's chief executive stated in April 2012 that agreement was close on a second contract for the development of the deep layers; the company reiterated this in September $2012 .{ }^{113}$

The Umid field, which is licenced to Socar, was explored from 2009, and the discovery of both gas and oil confirmed in November 2010, from a well drilled to 6,006 metres. At the time of writing, a second well is being drilled into the same geological structure. ${ }^{114}$

Two other substantial prospects are the subject of agreement between Socar and foreign companies: the Shafag-Asiman structure, a PSA covering the exploration and development of which was signed by Socar and BP in October 2010; and the Nakhchivan structure, being explored by RWE under a memorandum of understanding signed with Socar in 2010. In addition, there are blocks licenced to Socar itself where exploration is being conducted: the Babek fields, and some smaller deposits. ${ }^{115}$

Another prospective area, the Alov, Araz and Sharg prospects, is covered by a PSA signed by BP, Statoil and Socar with the Azeri government in 1998. Technical evaluations of the area were made in 2002, but work has stopped since then because of a dispute between Iran and Azerbaijan about the position of maritime boundaries. Little progress has been made in talks between the two governments; these fields have therefore not been included in the above table of projects with the potential for development.

The main factor that makes likely the continued expansion of offshore gas production, after Shah Deniz II is commissioned in 2017, is the emphasis that the Azeri government is placing on developing the gas resource. Not only does the government see rising gas output as a key strategy to counter the decline of oil production, but it has also cooperated with international oil companies on major hydrocarbons development projects over a longer period, and with greater success, than Uzbekistan or Turkmenistan, and appears to be more disposed to continue to do so than Kazakhstan. There remains, however, (i) doubts about the transport and marketing issues related to Shah Deniz II gas will be resolved, which are discussed further in section 5.5 below, and (ii) significant constraints on other fields, i.e. a range of infrastructure and logistical problems associated with field development in the Caspian, which is landlocked and only accessible to vessels via the Volga-Don canal from Russia. The most serious of these logistical problems is the shortage of exploration rigs. Of the handful of floating and semi-submersible rigs in the Caspian, the one most suitable for working at great depths and at high pressure, the Heydar Aliev (Maersk Explorer), was returned to the Shah Deniz field in 2012 after a spell at Absheron. The other semi-submersible rigs available in the

\footnotetext{
112 Zulfugar Agayev, “Total, GDF Confirm Gas Find”, Bloomberg, 2 July 2012; presentation by Bertrand Chevalier, Total, at the Caspian Oil and Gas conference, May 2012, Baku.

113 "Socar to sign gas agreement with BP in 2012", Reuters, 10 April 2012; "Azerbaijan prepares new contract", Bloomberg Business News, 6 September 2012.

${ }^{114}$ Socar web site $<$ http://new.socar.az/socar/en/activities/exploration/umid $>$

${ }^{115}$ From companies' reports and web sites
} 
Azeri sector, the Dada Gorgud and Istiglal, are in use at ACG and Shah Deniz respectively. At the time of writing, Socar had begun talks with Total, BP and other companies working in the Caspian about the possibility of building two more semi-submersible rigs for the Caspian, the first of which could be launched as soon as 2014. The other factor on which the pace of Azeri offshore development depends is the development of the markets into which Azeri gas is likely to be exported, i.e. Turkey and European countries, which will influence the financing of projects. A senior Total executive, commenting on the prospects for Absheron just after the announcement of commerciality, stated that rig constraints and the great expense of the project were the two "major challenges". 116

Senior Socar executives have projected up to $50-55 \mathrm{bcm} /$ year of total production, and 40 $\mathrm{bcm} /$ year of sales gas output, by 2020 , and these appear to be achievable aims - subject to exploration success on identified prospects. Rovnag Abdullayev, CEO of Socar, recently projected an increase of total production (i.e. prior to own use, flaring, etc) from $25.7 \mathrm{bcm}$ in 2011 to $50-55 \mathrm{bcm}$ in $2025 .^{117}$ His senior deputy forecast that the volume of sales gas produced will rise from $16.4 \mathrm{bcm}$ in 2011 to $20 \mathrm{bcm}$ in 2020 and $40 \mathrm{bcm}$ in $2025 .{ }^{118}$ Let us assume that the output from currently producing fields falls only slightly, e.g. in round numbers from $26 \mathrm{bcm}$ to $25 \mathrm{bcm} /$ year (i.e. that slightly more gas is reinjected by ACG as pressure falls, and that the output of Socar's own fields stays level); and that $16 \mathrm{bcm}$ is added, as planned, from Shah Deniz II. This amounts to $41 \mathrm{bcm} /$ year of output. The implication of Abdullayev's projection is that within 12 years a further $9-14 \mathrm{bcm} /$ year of production can be added. Given the size of the discovered fields, the remaining identified prospects, the general capability of the industry, and the level of government support for achieving this target, it seems realistic. The caveat is that success is dependent on measures being taken in the near future to address the infrastructure squeeze in the Caspian. (These estimates are shown in Table 24, below in section 5.5 on Azeri exports.)

\subsection{The region's other producers}

Apart from output by the four countries covered, the only other gas sure to be produced in this decade in the Central Asian/Caspian region is associated gas from oil fields in the Russian section of the Caspian Sea. These small, but growing, volumes will be processed in southern Russia and fed into the Russian gas supply system, and will therefore impact only indirectly on the market for gas from the other Central Asian and Caspian producers. To the south, Iran has the second-largest gas reserves in the world - but, apart from a possible substitution of domestic gas for Turkmen imports, Iran will only have an effect on its Caspian neighbours if and when the sanctions against it by the UN and major consuming countries are lifted. In the eastern part of the region, gas resources in Tajikistan, Kyrgyzstan and Afghanistan could be produced in future.

Russia. The increase in production at Lukoil's North Caspian oil fields in the coming years could bring substantial volumes of associated gas. Lukoil has licences covering six fields, in which it reported proved gas reserves of $170 \mathrm{bcm}$ in 2008; production was launched in 2010 at the Yuri Korchagin field, the first to be developed. Output from the field rose to 338,100 tonnes of oil in 2011; in its most recent annual report the company projected peak output of

\footnotetext{
116 "Socar in plan to build Caspian semisubs", Upstream, 3 February 2012; Caspian Drilling Co. web site; presentation by Christian Guidicelli of Total at the Caspian Gas Forum, July 2012, Istanbul.

117 “Scalability as Drawn”, Azerbaijan 2012: The Business Year, pp. 92-93

${ }^{118}$ Presentation by Khoshbakht Yusifzade, vice-president of Socar, at the Caspian Oil and Gas Conference, Baku, May 2012.
} 
2.4 million tonnes/year of oil and $1 \mathrm{bcm} /$ year of gas from the field. The Sarmatskoye gas field nearby contains substantial reserves; its $\mathrm{C} 1$ gas reserves were increased by $55.6 \mathrm{bcm}$ in 2011 . The largest field, Filanovsky, could produce an estimated $8 \mathrm{bcm} /$ year at peak. ${ }^{119}$ The extent of associated gas utilisation from the fields will depend on developments in the Russian market. Lukoil has sought to invest in gas consumers who can buy the North Caspian production, and in 2008 bought TGK-8, the territorial power generation company in southwest Russia, in the area bordering the Caspian. Lukoil has also begun construction of a petrochemicals complex in the region, Stavrolen, which will require $2 \mathrm{bcm} /$ year of feedstock from 2015 for a first production line, and more thereafter. In March 2011 Lukoil reported that it had reached agreement with Gazprom under which Gazprom would "do all in its power" to accept North Caspian gas into the unified gas supply system; this is in line with the trend in the Russian market towards increased sales of non-Gazprom gas. ${ }^{120}$ If in future Central Asian exports are sold directly into the Russian market - rather than being sold on to Ukrainian and central European markets as they are at present - a substantial increase in production by Lukoil from the North Caspian will compete with them. Given the speed at which projects are developing, and the current oversupply of the Russian market, such competition is unlikely to take shape prior to the 2020 s.

Iran. Most of Iran's gas resources are in the south of the country and offshore in the Persian Gulf. Iran is currently undertaking a major development of transport infrastructure to bring gas to its northern regions, and this could result in Turkmen imports to northern Iran being substituted by domestic supplies, significantly impacting Turkmenistan's export trade (see section 5.4 below). Iranian exports to Turkey comprise competition for current and future Azeri exports, but Turkish-Iranian disputes over prices and commercial terms have made this relationship difficult long before Azerbaijan became a significant supplier to the Turkish market in $2007 .^{121}$

Tajikistan, Kyrgyzstan and Afghanistan. In Tajikistan, exploration for both oil and gas is being conducted by Tethys Petroleum which has signed a production sharing contract with the government covering 35,000 square $\mathrm{km}$ in the south-west of the country. The company reports audited resources of 1.13 billion boe in the "largely underexplored" territory. In 2011 it made a discovery of oil at East Olimtoi, is acquiring further seismic data and has stated that it is seeking a farm-in partner. ${ }^{122}$ In Kyrgyzstan, which has proven natural gas reserves of 2-6 $\mathrm{bcm}$, gas field development could be conducted by a joint venture between Kyrgyzgas and Gazprom. There were talks in 2006-08 between the Kyrgyz Republic and Gazprom about establishing a joint venture to undertake exploration and development; in early 2011 a memorandum was issued providing for these negotiations to be reopened; but there have been no results. ${ }^{123}$ In Afghanistan, CNPC was awarded exploration licences for three hydrocarbons blocks in the Amu Darya basin, which contain both oil and gas-condensate fields; in October 2012 it began producing small volumes of oil from the Angot field, which was discovered in 1967 and has produced oil in the past. ${ }^{124}$

\footnotetext{
${ }^{119}$ Lukoil Annual Report 2011; Henderson (2010), pp. 136-138.

${ }^{120}$ Lukoil Annual Report 2011

${ }^{121}$ See a detailed account in Kinnander (2010)

122 Tethys Petroleum Ltd, Management's Discussion and Analysis, 30 June 2012; Tethys company presentations

${ }^{123}$ Gazprom web site, "Kyrgyzstan” page; Gazprom press release of 7 September 2011, "Gazprom group to open its representative office in Kyrgyzstan"

124 “CNPC gets three Afghanistan Amu Darya blocks”, Oil \& Gas Journal, 16 January 2012; “CNPC producing oil from Afghan block”, Oil \& Gas Journal, 24 October 2012.
} 
The main incentive for Tajikistan and Kyrgyzstan to develop local gas resources would be to reduce their dependence on imports from Uzbekistan and other suppliers - but Tajikistan has prioritised hydro power as the main alternative to gas imports, and Kyrgyzstan could also choose to diversify to other energy sources. The other possibility for gas resources in eastern Central Asia is that they could be developed for export, but this would depend heavily on transport infrastructure. The possibility of routing a future pipeline to China via Tajikistan and Afghanistan has been mooted (see section 5.6 below), while the possibility of pipelines running south-east to Pakistan and India from either Iran or Turkmenistan has also long been the subject of political discussion. Should any of these transport projects ever go ahead, resources in Tajikistan and Afghanistan, as well as Turkmenistan, could supply them.

\section{Domestic markets and intra-Central Asian trade}

Uzbekistan consumes about $50 \mathrm{bcm} /$ year of gas; Azerbaijan about $10 \mathrm{bcm} /$ year; Kazakhstan's consumption is small (around 8-13 bcm/year), but likely to grow; and Turkmenistan's is large, given its small population ( $15 \mathrm{bcm} /$ year). Obligations to supply these markets will be a constraint on exports, especially from Uzbekistan.

\subsection{Uzbekistan}

Uzbekistan has one of the most energy-inefficient economies in the world, and most of this energy is supplied as natural gas. Its consumption of around $45 \mathrm{bcm} /$ year in recent years is greater than that of Turkey, Spain or France. Uzbekistan is the third-largest consumer of gas among the former Soviet countries (after Russia and Ukraine), and consumes more gas than the rest of Central Asia and the Caucasus put together. As Table 13 shows, Uzbekistan consumes less gas per person than Russia (about 1,900 cubic metres of gas per person, compared to Russia's 3,200 cubic metres per person), while Uzbekistan's total primary energy supply per person is little more than one-third of Russia's. But for each unit of fuel consumed, Russia produces more than four times as many units of GDP. Thus while Uzbekistan's primary energy supply is less than one-thirteenth of Russia's, its economy is about one-sixtieth of the size.

Table 13: Selected Economic Indicators for Uzbekistan, Russia and Ukraine

\begin{tabular}{|c|c|c|c|}
\hline \multicolumn{4}{|c|}{$\begin{array}{l}\text { Table 13. Selected economic indicators for Uzbekistan, Russia and } \\
\text { Ukraine }\end{array}$} \\
\hline 2008 & Uzbekistan & Russia & Ukraine \\
\hline Population (end-year, million) & 27.7 & 142.0 & 45.8 \\
\hline GDP per capita (in US dollars) & $1,007.4$ & $11,739.1$ & $3,930.8$ \\
\hline TPES, (mtoe) & 50.5 & 687 & 137 \\
\hline Gas consumption (bcm) & 53.5 & 453.43 & 66.77 \\
\hline TPES/unit of GDP* & 0.55 & 2.42 & 1.31 \\
\hline TPES/person (tonnes of oil equivalent) & 1.8 & 4.8 & 3.0 \\
\hline Gas consumption per person $(\mathrm{mcm})$ & 1.9 & 3.2 & 1.5 \\
\hline
\end{tabular}

Sources: UNDP; EBRD standard economic indicators; IEA

Note: * Total GDP, valued in dollars, divided by total TPES, in mtoe. A higher number represents a greater amount of economic output per unit of energy input. 
This section will (i) review Uzbekistan's gas consumption; (ii) refer to government energy efficiency policies; and (iii) suggest why demand may continue to rise.

\section{Causes and consequences of high gas consumption}

Uzbekistan shares with all former Soviet countries the legacy of Soviet industrialisation and urbanisation policies of the 1960s-1980s, which led to the construction of a power sector and industry fuelled at first by cheap domestic coal, and then increasingly by cheap domestic gas. Urban infrastructure included district heating systems fuelled by gas, and municipal service provision that often included gas for cooking. Uzbekistan's electricity sector is almost entirely gas-fired, except for one power station that runs on brown coal (which is all that is available domestically) and one hydroelectric station - in contrast to Russia, which has coal and nuclear alongside gas, and Ukraine, where nuclear and coal account for almost all generation, and only about $10 \%$ of electricity is produced from gas. Uzbekistan also suffers a disadvantage with respect to the urban district heating systems it inherited from the Soviet Union: whereas in Russia these are supplied by combined heat and power (CHP) plants, which were comparatively efficient when they were built, Uzbekistan relies almost entirely on gas-fired boilers.

Since independence Uzbekistan has, on one hand, sought more than most other former Soviet countries to use domestic gas resources as a direct economic benefit to the population, and, on the other, consistently followed economic policies directed at self-sufficiency (as discussed above in section 2), latterly seeking to use state intervention to stimulate the development of small business. These policy trends have tended to push gas consumption upwards in several ways:

First, Uzbekistan has installed gas distribution pipelines in the countryside perhaps more widely than in any other country. The level of gasification has risen sharply throughout the post-Soviet period, from under half in 1990 to more than three-quarters in 2000. It continued to rise thereafter, surpassing $85 \%$ in 2011 . The level of gasification in Russia, by comparison, has still not reached two-thirds, as Table 14 shows.

Table 14: Uzbekistan and Russia: levels of Gasification

\begin{tabular}{|l|r|r|r|r|r|r|r|r|}
\hline \%o of population & $\mathbf{1 9 9 0}$ & $\mathbf{1 9 9 5}$ & $\mathbf{2 0 0 0}$ & $\mathbf{2 0 0 5}$ & $\mathbf{2 0 0 9}$ & $\mathbf{2 0 1 0}$ & $\mathbf{2 0 1 1}$ \\
\hline Uzbekistan & 44.6 & 60.2 & 75.9 & 83.2 & 84.8 & 85.0 & 85.4 \\
\hline Russia & $\mathrm{n} / \mathrm{a}$ & $\mathrm{n} / \mathrm{a}$ & $\mathrm{n} / \mathrm{a}$ & 54.2 & 62.4 & 62.9 & 63.1 \\
\hline Russia (rural areas) & $\mathrm{n} / \mathrm{a}$ & $\mathrm{n} / \mathrm{a}$ & $\mathrm{n} / \mathrm{a}$ & 36.0 & 44.9 & 45.8 & 46.7 \\
\hline
\end{tabular}

Sources: Uzbekskii zhurnal nefti i gaza, May 2012, p. 39; Gazprom in Figures, various years

The extraordinary and expensive spread of pipeline gas was combined, at least until the mid 2000s, with very low tariffs that comprised a negligible part of Uzbek household budgets. It may be assumed that these policies reinforced among Uzbek people the strong sense of entitlement to cheap gas that is common among the population of most hydrocarbonproducing countries. It is significant, too, that while tariffs for households have risen substantially, the limited statistical information available does not suggest that consumption has fallen. Tariffs for households were around $\$ 10-11 / \mathrm{mcm}$ in the mid $2000 \mathrm{~s}$; they rose to $\$ 13-28 / \mathrm{mcm}$ in 2007 and $\$ 47-104 / \mathrm{mcm}$ in 2012. The main tariffs are shown in Table 15 . 
The figures for household tariffs should be read with two caveats. The first is that the dollar equivalents have been worked out on the basis of the official exchange rate; at the real (unofficial) exchange rate, tariffs in 2012 are around $\$ 32-69 / \mathrm{mcm}$, rather than $\$ 47-104 / \mathrm{mcm}$ (before discounts). The second is that large amounts of gas are available at various discounts. For example all residents of multi-apartment blocks are still charged for gas under a complicated flat-tariff system, inherited from the Soviet Union (e.g. 2,000-2,800 som per person per month in some areas, and more heavily discounted in others), which, given the gaps in the metering system, encourages consumption to rise to a higher level than it otherwise might. The third is that, according to anecdotal evidence, because the gas distribution network is so widespread but also of poor quality, diversion of gas from the network, under informal arrangements with distribution companies, is common.

While Uzbekistan's policy of providing cheap gas to households is not dissimilar from that of other former Soviet countries, it has also in recent years implemented schemes that promote energy-intensive small businesses, that receive discounted gas and use it very inefficiently. It can be seen from Table 15 that discounted categories of wholesale customers have access to the cheapest gas, costing around $\$ 28 / \mathrm{mcm}$ at official exchange rates. This discount, awarded by presidential decree in 2007, was designed to stimulate small business in rural areas and to combat unemployment. One result has been the establishment of a large number of small brickworks; officials at one international institution in Tashkent estimate there are 800 of these, which use $1 \mathrm{bcm} /$ year of gas in total. Anecdotal evidence further suggests that many people have taken advantage of this measure to set up other energy-intensive forms of small business, e.g. tomato gardens and bakeries.

Table 15: Gas Tariffs in Uzbekistan (per mcm)

\begin{tabular}{|c|c|c|c|c|c|}
\hline & & & $\begin{array}{c}\text { From } \\
\text { Oct } \\
2010 \\
\end{array}$ & $\begin{array}{c}\text { From } \\
\text { Oct } \\
2011 \\
\end{array}$ & $\begin{array}{c}\text { From } \\
\text { Apr } \\
2012 \\
\end{array}$ \\
\hline \multicolumn{3}{|c|}{ Exchange rate (Som per US\$) } & 1640 & 1795 & 1800 \\
\hline \multirow{6}{*}{$\begin{array}{l}\text { Wholesale } \\
\text { prices }\end{array}$} & \multirow[t]{2}{*}{ Wholesale customers, incl. power } & Som & 91800 & 108000 & 116100 \\
\hline & & US \$ & $\mathbf{5 5 . 9 7}$ & 60.17 & 64.50 \\
\hline & \multirow[t]{2}{*}{ District heating companies } & Som & 72000 & 94500 & 107700 \\
\hline & & US \$ & 43.91 & 52.65 & 59.83 \\
\hline & \multirow{2}{*}{$\begin{array}{l}\text { Discounted categories, incl. makers } \\
\text { of bricks, building materials, } \\
\text { ceramics, etc. }\end{array}$} & Som & 51000 & 51000 & 51000 \\
\hline & & US \$ & 31.10 & 28.41 & 28.33 \\
\hline \multirow{6}{*}{$\begin{array}{l}\text { Household } \\
\text { tariffs }\end{array}$} & \multirow[t]{2}{*}{ With meter } & Som & 67500 & 94500 & 107700 \\
\hline & & US \$ & 41.15 & 52.65 & $\mathbf{5 9 . 8 3}$ \\
\hline & \multirow{2}{*}{$\begin{array}{l}\text { Without meter, for hot water \& } \\
\text { cooking }\end{array}$} & Som & 116700 & 163390 & 186265 \\
\hline & & US \$ & 71.16 & 91.02 & 103.48 \\
\hline & \multirow[t]{2}{*}{ Without meter, for heating } & Som & 54116 & 75770 & 86380 \\
\hline & & US \$ & 32.99 & 42.21 & 47.99 \\
\hline
\end{tabular}

Source: web site of the ministry of finance of Uzbekistan

Note: Many households are charged under a separate system, i.e. A fixed monthly tariff per person calculated separately for heating, cooking, etc, with a system of regional and other discounts

* Exchange rate: IMF, Uzbekistan Economic Indicators (2010 and 2011); author's observation (2012). These are official rates; the actual (unofficial) exchange rate is 2600-2800 som per US \$. 
Since the mid 2000s, gas demand has been stimulated not only by these government policies, but also by a shortage of gasoline and other oil products. In line with its long-standing aspirations to self-sufficiency and import substitution, the government has responded to this crisis with an energetic programme to convert road transport vehicles to compressed natural gas (CNG).

The dramatic nature of Uzbekistan's difficulty is shown in Figure 1, which shows the production and consumption of both oil (including oil products) and gas.

Figure 1: Uzbekistan: gas and oil*production and consumption

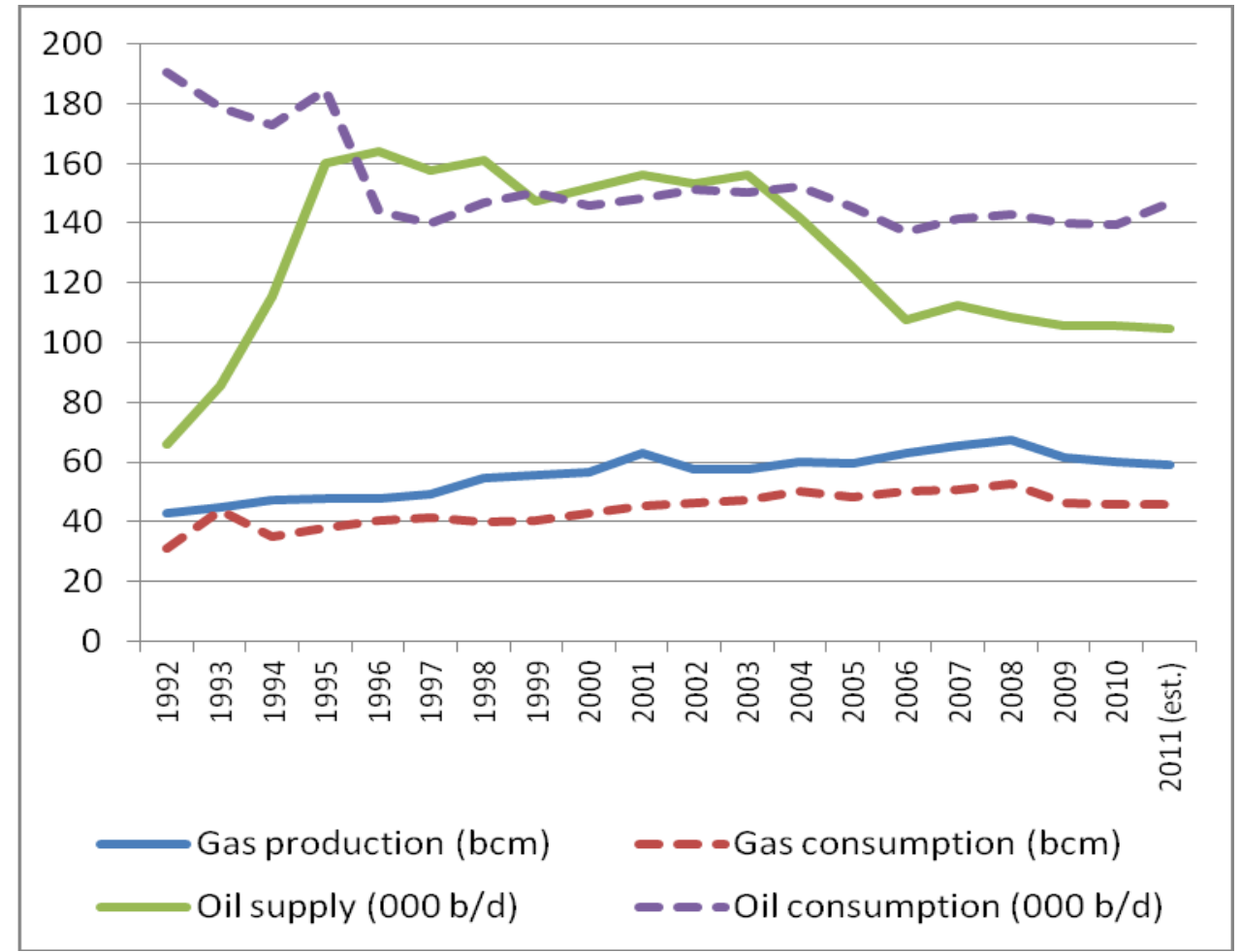

Source: EIA international energy statistics. Gas, 2011: Table 4 above

* Oil = crude oil plus oil products

Since about 2004, Uzbekistan's oil consumption has remained steady but its oil production has fallen, with the result that it has had to import oil products, in the first place from Kazakhstan. Media reports indicate that there have been occasional shortages of gasoline in Uzbekistan, e.g. in 2007, when Kazakhstan imposed a temporary export ban due to its own shortages, and again in 2010. The Uzbek government has taken measures to fill this gap with CNG produced domestically. In 2010 Uzbekneftegas entered into a partnership agreement with the Korean ministry of environment and Kogas to manufacture CNG bottles in the Navoi special economic zone and to construct a network of gas stations. ${ }^{125}$ Anecdotal evidence from a research visit to Uzbekistan in 2012 indicates that use of the bottles is widespread, at least in Tashkent.

The constant proliferation of sources of demand for Uzbek gas, combined with the problem (common to all former Soviet states) of aging infrastructure, has for the last several years pushed the distribution system to its limits at periods of peak demand. In 2011-12,

${ }^{125}$ Uzbekneftegaz, Ekonomicheskoe obozrenie no. 11 (133), November 2010 $<$ http://www.ung.uz/ru/press_center/smi/econom_11_2010>; "V Uzbekistane - ostryi defitsit benzina", Ferghana News, 1 November $2010<$ http://www.fergananews.com/article.php?id=6783> 
Uzbekistan's supply squeeze appears to have contributed to reductions of its exports to Russia and to central Asian countries. In the winters of 2010-11 and 2011-12, the strain on the distribution system resulted in unscheduled cuts in the supply of gas, heating and electricity that were more extensive than in previous years. No information is available from official sources on the scale of this problem. However in November 2011 the government announced that the heavily-populated Andizhan district of the Ferghana valley would rely solely on coal for heating purposes over the winter; the head of the administration of another district, Rishtansky, urged residents to collect firewood and coal to ensure that their heating needs were met; and authorities in Tashkent were directed to draw up a list of 500 industrial enterprises that could if necessary have their gas supply cut off. ${ }^{126}$ A very large number of reports in the media suggested that in many towns outside Tashkent, gas and electricity cuts of many hours' duration were an almost daily occurrence. These are summarised in Appendix 5. As for exports, in 2011 Uzbek exports to Russia fell to $8 \mathrm{bcm}$, their lowest level since the mid-2000s; this was attributed by Gazprom managers to Uzbekistan's problems in meeting domestic demand. In the winter of 2011-12, Kazakhstan, Kyrgyzstan and Tajikistan all experienced interruptions in the supply of gas from Uzbekistan, and all sought alternative supplies of gas, principally from Turkmenistan. This had a knock-on effect in China, where it was reported that Turkmengaz asked for a $0.5 \mathrm{bcm}$ reduction in import volumes over the winter, to accommodate additional demand in central Asia. ${ }^{127}$

\section{Energy efficiency policies}

Uzbekistan's excessive and inefficient consumption of gas does not have one simple cause. The factors at work include some, such as the power sector's heavy dependence on gas, and the predominance of gas-fired boilers for urban district heating, inherited from the Soviet Union. Others - such as rural gasification, state stimulation of small, energy-intensive industry, and the provision of cheap gas to households - stem from post-Soviet Uzbek governments' economic and social policy decisions. Finally there is the exhaustion of infrastructure, and specifically distribution networks - which operate with heavy gas losses that Uzbekistan, along with most other former Soviet states, has done little to address.

In response to these problems, Uzbekistan has adopted legislation aimed at more efficient energy use, starting with the 1997 law "on the rational use of energy resources". There have been many subsequent initiatives by the government, some specifically aimed at gas consumption (e.g. a national energy saving programme adopted in 2005 that set the target of reducing gas consumption to $32 \mathrm{bcm} /$ year by 2020). ${ }^{128}$ However such aims have not been fully implemented, probably because (i) energy efficiency aims do not receive the highest priority when it comes to allocating resources, and (ii) it is not clear to officials responsible for implementation how to deal with the tension, and even direct conflict, between energy efficiency aims and other policy initiatives.

In recent years, as the danger of a gas supply gap has become more evident, fresh efforts have been made, some involving cooperation between the government and international institutions. First, Uzbekistan has launched 13 energy-saving projects under the UNFCCC

\footnotetext{
126 "Uzbekistan: svyshe 500 prepriiatii Tashkentsoi oblasti budut otkliucheny", Ferghana News, 25 October 2011; “Uzbekistan: zhiteliam Ferganskoi oblasti rekomandovano zapastis'm drovami i uglem”, Ferghana News, 9 November 2011.

${ }^{127} \mathrm{Xu}$ Yihe, "China turns taps to fill Turkmen gas shortfall”, Upstream, 20 January 2012

${ }^{128}$ Paramonov (2008), p. 4.
} 
clean development mechanism including one on gas transportation, one on gas distribution and one on landfill gas. Other projects, including some to improve energy efficiency in public buildings, have been funded by the Global Environment Facility. ${ }^{129}$ Second, the government is developing energy efficiency projects together with the World Bank both in the power sector (e.g. with a metering project launched in 2012) and in industry, e.g. to introduce heat recovery in cement production, to upgrade air separation equipment, and to modernise fertiliser manufacture. Third, Uzbekneftegaz has launched a programme to reduce leakage in gas transportation and distribution networks with projected aggregate savings of 0.3 bcm/year. ${ }^{130}$

\section{Future demand trends}

Despite the adoption of the energy efficiency policies mentioned, Uzbekistan may well increase its gas consumption in the coming years. Even if e.g. residential consumption falls as discounts continue to be reduced, and the efficiency of municipal supply systems improves, the resulting reductions could be offset by rising population. Moreover, the government is not only likely to continue to support energy-intensive small businesses, but is also working, together with foreign partners and international agencies, towards its long-term goal of establishing major petrochemical projects, each one of which could add up to $1 \mathrm{bcm} / \mathrm{year}$ to demand. The most advanced projects are:

- The Ustiurt gas-chemical complex, a $\$ 4.1$ billion project to be based at the Surgil gas field, comprising a gas separation plant, and units producing 400,000 tonnes/year of high-density polyethylene, 100,000 tonnes of polypropylene and 110,000 tonnes of pyrolised gasoline, scheduled to start production in 2016 . It will require $4.5 \mathrm{bcm} /$ year of natural gas feedstock from Surgil and nearby fields, and its projected output of sales gas is $3.7 \mathrm{bcm} /$ year, implying a use of $0.8 \mathrm{bcm} /$ year in the complex. This is a joint venture between Uzbekneftegaz (50\%) and Kor-Uz Gas Chemical (50\%), which is owned $45 \%$ by Korea Gas Corporation, $45 \%$ by Honam Petrochemical and $10 \%$ by STC Energy. In May 2012, an engineering, procurement and construction (EPC) contract was signed for this project and a $\$ 2.54$ billion loan agreement signed between Uzbekneftegaz and a consortium of banks including the Asian Development Bank, the Export-Import Bank of Korea and the China Development Bank. ${ }^{131}$

- The Uzbekistan GTL project. This is a \$2-2.5 billion project, to be sited near the Shurtan gas processing plant, to produce 1.1 million tonnes/year of synthetic liquid fuels (diesel oil, jet fuel, naphtha and LPG. The gas demand implications are more substantial: it will require $3.5 \mathrm{bcm} /$ year of feedstock. This is a joint venture between Uzbekneftegaz (44.5\%), Sasol of South Africa (44.5\%) and Petronas of Malaysia $11 \%)$. Technip of Italy completed the first stage of front-end engineering and design (FEED) in 2010 and is due to complete the remainder by $2013 .{ }^{132}$

\footnotetext{
${ }^{129}$ UNFCCC clean development mechanism web site $<$ http://ji.unfccc.int $>$

${ }^{130}$ Uzbekneftegaz, "Prioritet realizuemoi politiki - povyshenie energoeffektivnosti", Ekonomicheskoe obozrenie no. 11, 2010; World Bank press release, "World Bank Helps Reduce Energy Losses, 27 March 2012; V.V. Eshmuratov, "Edinaia tekhnologicheskaia sistema po transportirovke i realizatsii prirodnogo gaza", Uzbekskii zhurnal nefti i gaza, May 2012, p. 94.

131 “Uzbekistan gets $\$ 2.54$ bln in loans for gas project”, Reuters, 21 May 2012; ADB press release, “ADB to help develop Uzbekistan's largest petrochemical plant”, 25 January 2012; Uz-Kor Chemical, UZB: Surgil Natural Gas Chemicals. Environmental Impact Assesment - Part 1.

${ }^{132}$ Technip press release, "Technip awarded gas-to-liquids contract", 13 December 2011; presentations by Neftegazinvest and by Simone Bonetti, Technip, at the Oil and Gas Uzbekistan conference, May 2012, Tashkent
} 
Other petrochemicals projects that have been discussed by Uzbekneftegaz and foreign partners are (i) the addition of an ethylene plant to the Shurtan gas processing plant; (ii) the installation at the Mubarek complex of petrochemicals manufacture capacity (polyethylene, gas condensate and diesel fuel). (This project was initially planned in 2008 by Zeromax, and has been revived in 2011-12 with the support of the ADB and with Indorama of Indonesia as the joint-venture partner.) ${ }^{133}$

Given the level of government support for these projects, it seems likely that one or more of them will go into construction. The Uzbekistan GTL plant, in particular, would produce substantial incremental gas demand.

The factors influencing Uzbek gas demand in the coming years may be summarised as follows:

Demographic. The steady increase of population will contribute to higher demand. Uzbekistan is the only one of the three principal former Soviet gas consumers with rising population (the other two are Russia and Ukraine).

Industrial policy. (1) Policies supporting small-scale energy-intensive industry. These may be scaled back, which would have a neutral effect, or continued, which would increase demand. (2) Policies supporting the petrochemicals sector and, in particular, the gas-to-liquids project. The incremental demand is small from the petrochemicals projects (less than $1 \mathrm{bcm} /$ year each), but more substantial if the GTL project goes ahead (3.5 bcm/year).

Social policy. (1) Upgrading of gas distribution networks. This is desperately needed in order to ensure security of supply for households. The results are difficult to predict: savings from elimination of waste may be cancelled by additional consumption by consumers whose supply improves. (2) Pricing policy. It seems likely that prices will continue to rise, but only gradually. Any reduction in demand may be cancelled out by increases resulting from population growth.

Energy sector. (1) Use of natural gas in transportation sector to substitute for oil products. This is likely to increase demand. (2) Modernisation in the power sector. This would decrease demand, but only gradually. (3) Energy efficiency measures. These will decrease demand, but only gradually.

\subsection{Turkmenistan}

Turkmenistan's economy is even more gas-intensive than Uzbekistan's; with a population of 5-6 million, it has consumed 15-17 bcm/year in recent years. Only a small amount of information about its gas consumption is available; the most recent statistics are shown in Table 16.

\footnotetext{
${ }^{133}$ Temur Malikov, "Shurtan dobavit etilena”, Podrobno.uz, 15 September 2010; presentations by Neftegazinvest and the ADB at the Oil and Gas Uzbekistan conference, May 2012, Tashkent
} 
Table 16: Turkmenistan: gas consumption (bcm)

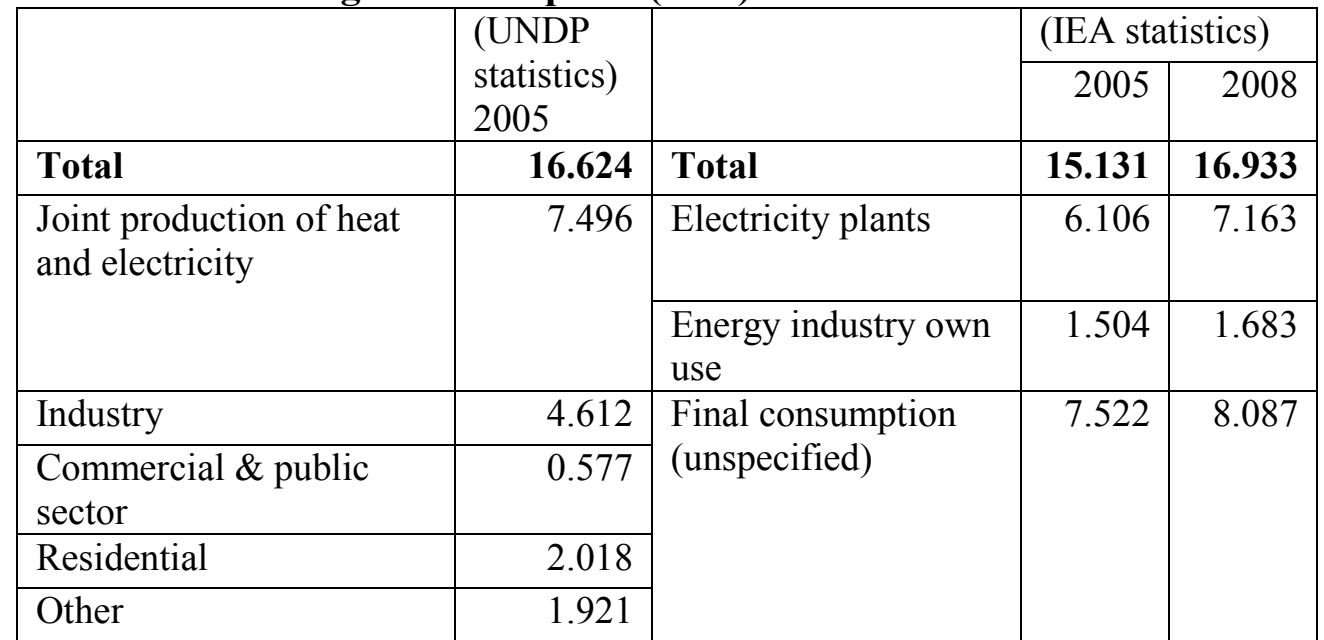

Notes: the author has assumed that the UNDP information was originally presented in petajoules, as the units are not specified. See UNDP, Strategiia razvitiia sistemy tsentralizovannogo teplosnabzheniia (proekt) (UNDP, Ashgabat, 2006). Table reproduced from Pirani (2010), p. 118

Both the UNDP and IEA figures suggest that $40-45 \%$ of the total gas consumed goes to the power sector, where gas accounts for $100 \%$ of fuel inputs. The UNDP attributes $27.5 \%$ to industrial use, $3.5 \%$ to commercial and $12 \%$ to residential customers. Not only is industry gas-intensive, but Turkmenistan has, like Uzbekistan, gone to great lengths to raise its level of gasification. Official sources state that it rose from $40 \%$ in 1990 to more than $90 \%$ in 1999 and to more than $99 \%$ in 2003. Turkmenistan, like Uzbekistan, sees cheap gas as a key economic support for industry and a social subsidy to the population. Tariffs for industrial customers are reportedly very low: industry sources indicated that in 2012 small businesses were paying 4 manat $/ \mathrm{mcm}(\$ 1.40 / \mathrm{mcm})$ inclusive of VAT for gas deliveries; payment is upon invoices and tariffs are not published. Residential customers receive gas free, under a policy devised by president Niyazov and reaffirmed by president Berdymukhammedov. Official Turkmen media reported in 2004 that $3.3 \mathrm{bcm} /$ year of gas was being distributed free, suggesting that free gas is available not only to residential users but elsewhere too. Moreover, Turkmen government policy has been to provide citizens with free electricity, water and salt, and free or heavily-subsidised gasoline and diesel fuel. ${ }^{134}$

\subsection{Kazakhstan}

Gas consumption in Kazakhstan is much lower than in Uzbekistan or Turkmenistan. There is a plentiful supply of coal, and in Soviet times energy and heat provision was mainly from coal. In post-Soviet times the Kazakh government has expressed aspirations to invest in gas infrastructure, to extend gasification - which is low by post-Soviet standards - and to invest in gas-intensive petrochemicals projects. As noted above in section 3.3, the government's policy objective is to raise consumption to $24 \mathrm{bcm} /$ year by 2020 . In the last few years some plans that will increase consumption have begun to be implemented, with support from the state and its oil windfall accumulated during the 2000s. A significant constraint on the plans will be the cost of building gas transportation infrastructure. Given the size of Kazakhstan

\footnotetext{
${ }^{134}$ Ukaz prezidenta Turkmenistana o bezvozmezdnom predostavlenii naseleniiu Turkmenistana prirodnogo gaza, 15 August 2003; "V 2003 godu naselenie Turkmenistana besplatno poluchilo 3.3 mlrd kubometrov gaza", Turkmenistan.ru, 15 April 2004; "Besplatnyi benzin Berdymukhammedova", Nezavisimaia Gazeta, 12 February 2008; "Kak zhivet strana pri prezidente Berdymukhammedova", Turkmenistan.ru, 14 November 2010; Pirani (ed.)(2009), pp. 284-288; Luong and Weinthal (2010), p. 99.
} 
and the distances involved, this means that gasifying some parts of the country could not be economically justified.

Kazakhstan's total consumption is currently somewhere between $6.5 \mathrm{bcm}$ and $12 \mathrm{bcm} /$ year. In 2010, Kaztransgaz reported total sales to customers of $8.48 \mathrm{bcm}$, up from 5-6 bcm in the three preceding years. Kaztransgaz stated that these sales amounted to more than $60 \%$ of total consumption, suggesting 12-13 bcm total consumption in 2010 and $8.5-9.5 \mathrm{bcm}$ in 2007-09. These figures are consistently higher than the total consumption reported by the state statistics agency, but close to figures used in research for and by the government. The statistics are shown in Table 17:

Table 17: Kazakhstan Gas Consumption Data

\begin{tabular}{|l|r|r|r|r|r|}
\hline bcm & $\mathbf{2 0 0 6}$ & $\mathbf{2 0 0 7}$ & $\mathbf{2 0 0 8}$ & $\mathbf{2 0 0 9}$ & $\mathbf{2 0 1 0}$ \\
\hline $\begin{array}{l}\text { Total (statistics agency } \\
\text { energy balances) }\end{array}$ & $\mathbf{8 . 5}$ & $\mathbf{6 . 8}$ & $\mathbf{6 . 7}$ & $\mathbf{5 . 8}$ & $\mathbf{6 . 6}$ \\
\hline $\begin{array}{l}\text { Total (distribution } \\
\text { company information)* }\end{array}$ & & $\mathbf{5 . 4 0}$ & $\mathbf{5 . 4 6}$ & $\mathbf{5 . 0 1}$ & $\mathbf{8 . 4 8}$ \\
\hline Kaztransgaz & & 0.54 & 0.37 & 0.67 & 3.24 \\
\hline Kaztransgaz Aimak & & 4.44 & 4.56 & 4.34 & 4.87 \\
\hline Kaztransgaz Almaty & & 0.96 & 0.91 & 1.08 & 1.11 \\
\hline Total (research) & $\mathbf{5 . 9 1}$ & & & & $\mathbf{1 1 . 9}$ \\
\hline
\end{tabular}

Sources:

* The distribution companies include intra-group sales in their individual statistics, but the total, reported by Kaztransgaz, is sales to customers only. It is therefore slightly less than the sum of the three rows that follow. Statistical agency energy balances: Agenstvo respubliki Kazakhstan po statistike, "Balansy resursov" 20062010, p. 26

Distribution company info: Kaztransgaz annual report, 2010.

Research: research commissioned by government (2006); PFC energy (2010)

Due to its large size and infrastructure constraints, Kazakhstan is divided into several separate physical markets, as shown in Table K: The table shows consumption as estimated by researchers in 2006, and 2010, and the ministry of oil and gas's projections for consumption in 2020. The regions are shown in map 6. 


\section{Map 6: Kazakhstan Regions}

Map 6. Kazakhstan Regions

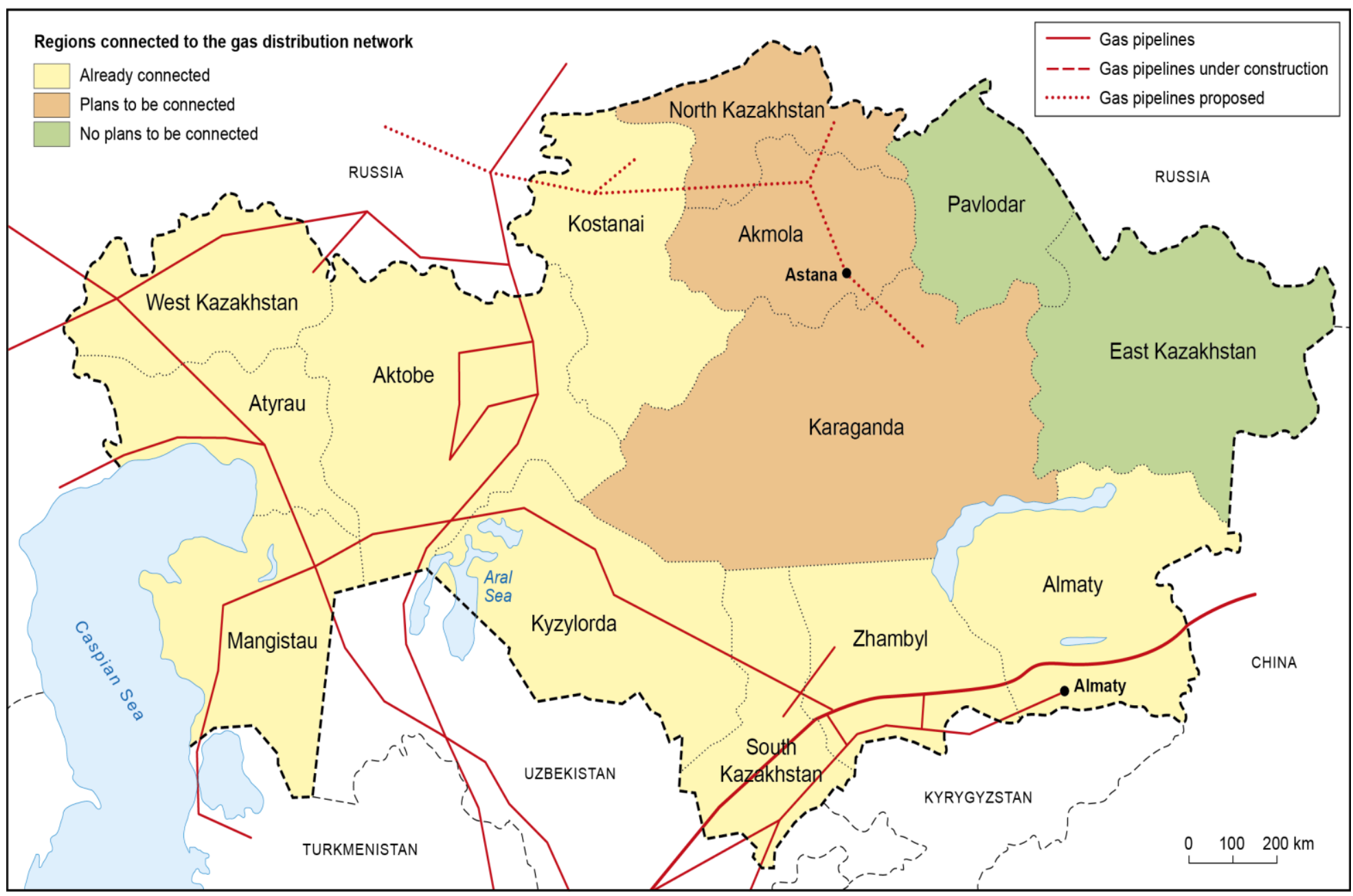


Table 18: Kazakh Gas Consumption by Region

\begin{tabular}{|c|c|c|c|c|}
\hline & 2006 & 2010 & $\begin{array}{l}2020 \\
\text { proj'd }\end{array}$ & Source of gas \\
\hline \multicolumn{5}{|c|}{ Western and southern regions supplied by local producers } \\
\hline West Kazakhstan & 0.54 & 1.2 & 1.7 & Karachaganak \\
\hline Atyrau & 0.5 & 2.7 & 4.3 & Tengiz (Tengizchevroil), some other \\
\hline Mangistau & 1.7 & 2.1 & 2.5 & Local fields (Kazmunaigaz and affiliates) \\
\hline Aktobe & 0.91 & 2.1 & 2.1 & $\begin{array}{l}\text { Zhanazhol field (CNPC-Aktobemunaigaz), } \\
\text { some other }\end{array}$ \\
\hline Kyzylorda & 0.1 & 0.3 & 1.4 & $\begin{array}{l}\text { Kumkol, South Turgai and other fields } \\
\text { (PetroKazakhstan, Kazgermunai (main owners } \\
\text { CNPC and Kazmunaigaz)), other }\end{array}$ \\
\hline \multicolumn{5}{|c|}{ Kostanai, supplied by swapped gas from Russia } \\
\hline Kostanai & 0.16 & 0.9 & 2.0 & $\begin{array}{l}\text { Imports from Russia, swapped for } \\
\text { Karachaganak exports }\end{array}$ \\
\hline \multicolumn{5}{|c|}{$\begin{array}{l}\text { Southern regions, supplied by swapped gas from Uzbekistan and small volumes of local } \\
\text { output }\end{array}$} \\
\hline South Kazakhstan & 0.4 & 0.9 & 1.3 & Imports from Uzbekistan, other \\
\hline Zhambyl & 0.57 & 0.7 & 1.3 & $\begin{array}{l}\text { Amangeldy field (Kaztransgaz), imports from } \\
\text { Uzbekistan, other }\end{array}$ \\
\hline Almaty & 1.03 & 1.0 & 2.2 & $\begin{array}{l}\text { Imports from Uzb., swapped for Karachaganak } \\
\text { exports }\end{array}$ \\
\hline \multicolumn{5}{|c|}{ Central and north-eastern regions with no gas infrastructure } \\
\hline North Kazakhstan & 0 & 0 & 1.0 & \\
\hline Akmola & 0 & 0 & 2.5 & \\
\hline Karaganda & 0 & 0 & 1.5 & \\
\hline Pavlodar & 0 & 0 & 0 & \\
\hline East Kazakhstan & 0 & 0 & 0 & \\
\hline Total & 5.91 & 11.9 & 23.8 & \\
\hline
\end{tabular}

Sources: 2006: research commissioned by government. 2010: PFC Energy. 2020 projections: oil and gas ministry

Some features of these markets, and of the gasification campaign, are:

\section{Western and southern regions supplied by local producers}

The hydrocarbons-producing regions of Atyrau, Aktobe and Mangistau between them account for more than half of Kazakhstan's consumption $(2.7 \mathrm{bcm}, 2.1 \mathrm{bcm}$ and $2.1 \mathrm{bcm}$ respectively in 2010). Atyrau's main supplier is Tengizchevroil, and there is sufficient associated gas potentially available that the construction of a petrochemicals plant there has long been under discussion; Aktobe region is supplied by CNPC-Aktobemunaigaz; Mangistau by Ozenmunaigaz and other Kazmunaigaz affiliates. The gas distribution infrastructure in all three is outworn. In Aktobe, the commissioning in 2005 of the $5 \mathrm{bcm}$ Zhanazhol-OktyabrskAktobe pipeline from CNPC-Aktobemunaigaz's Zhanazhol field to the Bukhara-Urals pipeline brought gas to Aktyubinsk city and other urban areas, substituting for gas that had previously been imported from Uzbekistan. In Mangistau, one of Kazakhstan's poorest regions, Kaztransgaz in 2009 consolidated distribution assets in its subsidiary Kaztransgaz 
Aimak. It stated that $300 \mathrm{~km}(13 \%)$ of the $2,320 \mathrm{~km}$ of distribution pipelines were unfit for use, and launched a 1,633 billion tenge ( $\$ 10.9$ billion) programme to upgrade distribution networks and extend gasification. ${ }^{135}$

West Kazakhstan is supplied, presumably with all its needs, from the Karachaganak field. A 3 bcm pipeline runs from the field to the city of Uralsk, which accounts for most of the region's consumption, and where the Zhaikteploenergo combined heat and power plant runs on gas.

Kyzylorda region is supplied mainly from the Kazgermunai joint venture. In 2004, a presidential decree on social measures in Kyzylorda provided for gasification. New gas transport infrastructure to supply associated gas to the local area was installed, the first such project in post-Soviet times, and this set a precedent that would be followed subsequently in other regions. A gas processing plant was commissioned at Kazgermunai's Akshabulak field, and a $123 \mathrm{~km}$ pipeline completed between that field and Kyzylorda city; in July this year three gas turbines were installed at the field to produce electricity for local use. By 2010 Kaztransgaz reported that the region was $77 \%$ gasified and that this would rise to $90 \% .{ }^{136}$

Kostanai region Gas is imported by Kazrosgaz to Kostanai via the Kartaly Kostanai pipeline, a $238 \mathrm{~km}$ branch line from the Bukhara-Urals line; in 2010 consumption was $0.9 \mathrm{bcm}$. The imports are undertaken by Kazrosgaz, in return for gas exported to Russia from Karachaganak.

\section{South-eastern regions, supplied mainly by imports from Uzbekistan}

Almaty, South Kazakhstan and Zhambyl regions in the south-east are the second large centre of gas consumption after western Kazakhstan, jointly consuming $1.7 \mathrm{bcm}$ in 2010. Since Soviet times these regions have been supplied by Uzbekistan, along the Kazakh section of the Bukhara Gas Region-Tashkent-Bishkek-Almaty (BGR-TBA) pipeline. Supply interruptions in winter, and political friction between the two countries, has led Kazakhstan to seek alternative sources of gas, including: (i) its own production from the Amangeldy field, which now accounts for most of the gas delivered to Zhambyl region, and (ii) gas from Turkmenistan, delivered via a link, completed in 2010, between the Central Asia-China pipeline and the BGR-TBA pipeline. In 2011 a small volume $(0.3 \mathrm{bcm})$ of Turkmen imports to Kazakhstan was reported, the first trade between the two countries for several years. ${ }^{137}$ Kazakhstan's main hope for ending its dependence on Uzbek imports altogether is the completion of the Beineu-Shimkent pipeline, which will bring gas from western Kazakhstan to the south and south-east.

The south-eastern regions have also been at the forefront of the gasification campaign. In Almaty region, Kaztransgaz in 2009 began a 35 billion tenge (\$233.1 million) distribution pipeline reconstruction project; this runs alongside a project entitled "gasification of microdistricts of Almaty and population centres in Almaty region". In Zhambyl, the akimat (local municipality) and Kaztransgaz are jointly implementing a campaign to raise the level of pipeline gas access from $53.5 \%$ in January 2010 to $60 \%$ by 2013 , which would expand the system to supply 15,000 extra households and involve construction of $400 \mathrm{~km}$ of distribution

\footnotetext{
${ }^{135}$ Kaztransgaz press release, “AO Kaztransgaz Aimak reanimiruet gazovuiu sistemu Mangistauskoi oblasti”, 1 August 2011; "Edinym operatorom na rynke gazosnabzheniia”, Aktau News, 3 September 2011.

${ }^{136}$ Kaztransgaz godovoi otchet 2010, "Investitstionnaia deiatelnost"”; "Na mestorozhdenii Akshabulak vvedeny v ekspluatatsiiu tri gazovye turbiny”, Kursiv, 12 July 2012

${ }^{137}$ Kaztransgaz Godovoi otchet 2010, "Kliucheviie sobytiia v realizatsii strategicheskikh prioritetov"
} 
pipelines. A similar programme in South Kazakhstan, prioritising the reconstruction of distribution networks in Shimkent city, projects a four-fold increase in the system's capacity between 2010 and 2018. ${ }^{138}$

\section{Regions with no gas transport infrastructure}

By far the most difficult aspect of Kazakhstan's gasification campaign is the expansion of the pipeline network into three northern regions - Akmola, Karaganda and North Kazakhstan. The government has identified gasification of Astana, the Kazakh capital, as a priority. Research commissioned by the government in 2006 concluded that this could "never" be done economically, but it appears to be proceeding in any case, for broadly political reasons. In April 2012 the minister of oil and gas, Sauat Mynbayev, announced that construction of a 1.5-2 bcm pipeline from Kartaly in the Chelyabinsk region of Russia to Kokshetau and Astana, which will be supplied with swapped gas imported from Russia, would begin in early 2013. (See Map 6.) Mynbayev acknowledged that gas would "not come cheap", and that even though state funding will be provided for pipeline construction, said that he expected prices of around $\$ 105 / \mathrm{mcm}$ at the border, plus $\$ 60 / \mathrm{mcm}$ transport and $\$ 50 / \mathrm{mcm}$ distribution, bringing the delivered price in Astana to $\$ 210 / \mathrm{mcm}$ for most customers and $\$ 160 / \mathrm{mcm}$ for a planned power station to be supplied directly from the high-pressure pipeline (i.e. net of distribution costs). In October 2012, Kazakh prime minister Serik Akhmetov said that a feasability study for the project had been approved, with an estimated investment cost of $\$ 1.33$ billion. ${ }^{139}$ The extent of this gasification - projected in government plans at $5 \mathrm{bcm} /$ year to three regions by 2020 - will depend on the state's willingness to fund the infrastructure expansion and is ultimately a political decision.

\section{Petrochemical plant}

Another project that will substantially increase Kazakhstan's gas demand is for the construction of a petrochemical plant, producing polyethylene and polypropylene, at Karabatan in Atyrau region, supplied by up to 6-7 bcm/year of feedstock gas by Tengizchevroil. While such plans have now been under discussion for many years, they received a significant boost in 2010-11, when agreements were made with China on construction, offtake and - most importantly - finance for the first phase of construction. Whether or not the project goes ahead will depend on whether the Chinese support is sufficient to bear the significant risks presented by rising costs.

A feasibility study for the plant was approved by the Kazakh energy ministry in 2007 and a project company, Kazakhstan Petrochemical Industries, incorporated. It is owned $51 \%$ by Kazmunaigaz Exploration \& Production, and $49 \%$ by Sat \& Company, a Kazakh private company that bought out the original minority shareholder, LyondellBasell of Switzerland, in 2010. A contract was signed in March 2009 with Tengizchevroil for supply of feedstock gas, underpinned by the conditions of its PSA on associated gas utilisation. In March 2010 Sinopec of China won a tender for construction of the first stage of the plant, to produce polypropylene, and simultaneously agreed to buy and export all the production. In February 2011 the Export Import Bank of China agreed with the Development Bank of Kazakhstan to provide \$1.38 billion in project finance for first-stage construction. In August 2011 LG Chem

\footnotetext{
${ }^{138}$ Kaztransgaz Godovoi otchet 2010, "Investitsionnaia deiatel'nost"”

${ }^{139}$ Kazrosgaz website, "Construction of gas pipeline in Central Kazakhstan is scheduled to begin in 2013", 27 April 2012. <http://www.kazrosgas.org/?nc142\&version=en>; Kazenergy website, "Stoimost' stroitel'stva gazoprovoda" < http://www.kazenergy.com/ru/2012-06-20-08-42-46/6562.html>
} 
of South Korea was awarded a $\$ 4$ billion contract to work on the second stage of the plant, for ethylene and polyethylene production. It has been reported that the main current danger to the project's success is further delay. Under the present timetable, it would go into production in 2016-17, with 15 years remaining of the Tengizchevroil PSA. Some commentators believe that with feedstock at relatively low prices guaranteed over any shorter period, the project could not be economic. ${ }^{140}$

\section{Gas market development}

In line with its aim of increasing domestic gas consumption, the Kazakh government has developed a programme of market development under which Kaztransgaz will assume the role of the dominant buyer of gas, operator of the pipeline system and dominant market participant. The new gas law that took effect in January 2012, mentioned above in section 3.3, specifies these functions. Currently, Kaztransgaz and its subsidiaries Kaztransgaz Aimak and Kaztransgaz Almaty distribute and supply most volumes consumed domestically; the law reinforces their position and provides a framework for the regulation of their activity and that of other market players.

Retail gas prices, which are regulated by the Agency for the Regulation of Natural Monopolies, will under the gas law also be subject to government approval. They vary widely across the country, depending on the source of gas - and vary in the producing regions depending on whether the source is associated or non-associated gas - as shown in Table 19, based on information published by Kaztransgaz Aimak.

The Programme for the Development of the Oil and Gas Sector adopted by the government in 2010 envisaged price increases, and eventual liberalisation, in line with the changes in the gas market in Russia - to which Kazakhstan is closely linked by infrastructure, and with which it shares membership of a Customs Union. This document referred to the necessity to "undertake a staged reform of pricing policy" for gas. It stated that in view of the prospect of price liberalisation in Russia, the preparation of "the introduction of staged price liberalisation" was necessary in Kazakhstan, and that this would be targeted at bringing prices to the level of European netback, minus $20-25 \%$. $^{141}$

Other publications of the OIES natural gas research programme have argued extensively that price reform in the Russian market will move gradually towards greater liberalisation, but that the original aim adopted in 2006 of achieving equivalence with European netback levels is likely to be abandoned, not least because European gas prices have increased so substantially in the meantime, and because conditions in the European market are now so uncertain. ${ }^{142}$ In Kazakhstan, the gas law ensures a dominant role in the wholesale market for Kaztransgaz (for domestically produced volumes) and KazRosGaz (for imported volumes), and control over transport and supply by Kaztransgaz. A gradual increase of consumer prices seems likely; how that revenue is shared with upstream sellers remains to be seen.

\footnotetext{
${ }^{140}$ Chemicals-Technology web site, "Kazakhstan Petrochemical Complex" page $<$ http://www.chemicalstechnology.com/projects/kazakhstan_petrochem>; KASE press release, 25 February 2011, "Development Bank of Kazakhstan signed an individual credit agreement with Eximbank of China"; Oksana Martyniuk, "Restart Kazakhstanskoi gazokhimii”, Kursiv, 12 July 2012; information from energy ministry and KPI web sites.

${ }^{141}$ Programma po razvitiiu neftegazovogo sektora $v$ Respublike Kazakhstan na 2010-2014 gody, approved by presidential decree no. 1072, 18 October 2010.

${ }^{142}$ Henderson (2011); Henderson, Pirani and Yafimava (2012).
} 
Table 19: Kazakhstan: selected retail gas prices

\begin{tabular}{|c|c|c|}
\hline \multicolumn{3}{|c|}{ Charged by Kaztransgaz Aimak, including VAT, transport and supply, from August 2011} \\
\hline & \multicolumn{2}{|c|}{ Price per mem } \\
\hline & tenge & $\$ * *$ \\
\hline \multicolumn{3}{|l|}{ Aktobe (gas from local fields) } \\
\hline Non-associated gas for residential and district heating & 7427.88 & 49.51 \\
\hline Non-associated gas for industry and heat to industry & 8148.67 & 54.56 \\
\hline Associated gas for residential and district heating & 3928.77 & 26.19 \\
\hline Associated gas for industry and heat to industry & 4685.55 & 31.24 \\
\hline \multicolumn{3}{|l|}{ Kyzylorda (gas from local fields) } \\
\hline Gas for residential and district heating & 4191.88 & 27.94 \\
\hline Gas for industry and heat to industry & 4984.66 & 32.99 \\
\hline \multicolumn{3}{|l|}{ South Kazakhstan (mainly gas imported from Uzbekistan) } \\
\hline Gas for residential and district heating & 19553.09 & 130.35 \\
\hline Gas for industry and heat to industry & 20309.88 & 135.39 \\
\hline \multicolumn{3}{|l|}{ Kostanai (gas imported from Russia)* } \\
\hline \begin{tabular}{l|l} 
Gas for residential and district heating \\
\end{tabular} & 14854.17 & 99.03 \\
\hline Gas for industry and heat to industry & 15610.95 & 104.07 \\
\hline
\end{tabular}

Source: web site of the Agency for the Regulation of Natural Monopolies (www.regulator.kz)

\subsection{Uzbek exports to other Central Asian countries, and the alternatives}

The export of Uzbek gas to Kazakhstan, Tajikistan and Kyrgyzstan, which began in Soviet times and has continued throughout the post-Soviet period, is in decline. Within the next few years it will probably stop all together. The opening of the Turkmen-China pipeline has made it easier for the importing nations to substitute Turkmen volumes for Uzbek ones, while Kyrgyzstan and Tajikistan hope further to reduce their reliance on imported gas by increasing their output of hydro electricity. The two main causes of these changes in the intra-Central Asian gas trade are the Uzbek gas supply squeeze mentioned above, and the deterioration in political relationships between the states, for reasons not directly related to the natural gas business. The main components of the intra-Central Asian gas trade, and the prices paid, are shown in Table 20. 
Table 20: The Intra-Central Asian Gas Trade

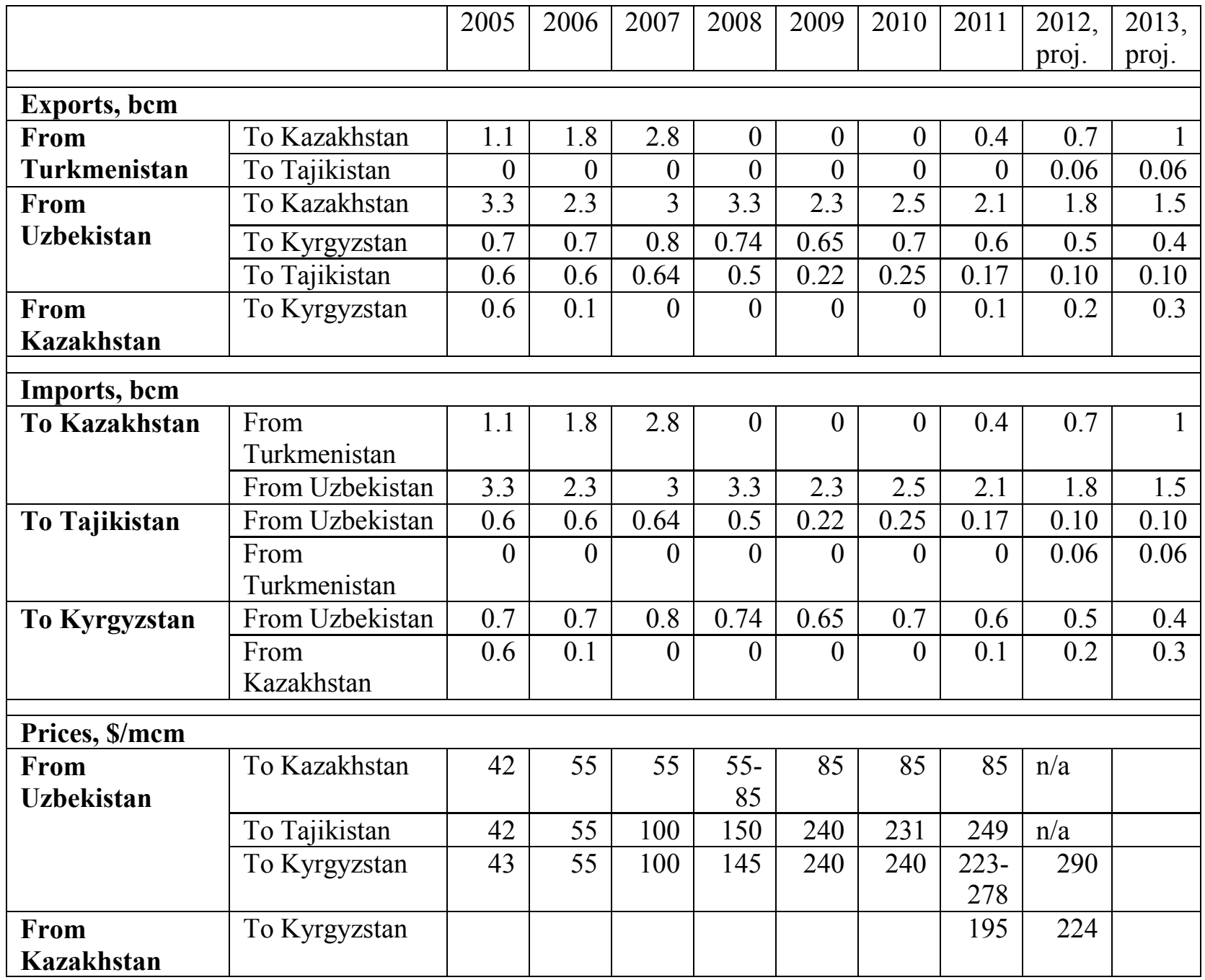

Sources: CIS statistics, press reports, company statements

The main features of the trade, by importing country, are as follows:

\section{Kazakhstan}

Kazakhstan has traditionally imported 2.3-3.4 bcm/year of Uzbek gas to supply the southeastern region (i.e. Almaty and South Kazakhstan regions, and part of Zhambyl region). The gas is imported along the Bukhara Gas Region-Tashkent-Bishkek-Almaty (BGR-TBA) pipeline that runs from the Bukhara gas producing area in Uzbekistan through Kyrgyzstan to south-east Kazakhstan. Throughout the post-Soviet period, Uzbekistan has frequently reduced deliveries, or failed to deliver, at peak consumption periods in the winter. The interruptions are attributed to the difficulties of balancing deliveries with peak demand, which are exacerbated by a lack of storage capacity and the poor state of the aging transport infrastructure. In December 2006, Gazprom, Uzbekneftegaz and Kaztransgaz entered into a swap arrangement whereby Gazprom became the supplier of Uzbek gas to south-east Kazakhstan, in return for volumes exported to Russia from north-west Kazakhstan. The Uzbek exports to Kazakhstan were priced at $\$ 55 / \mathrm{mcm}$. In December 2007, the agreement was renewed and the price held at that level, although Central Asian exports to and through 
Russia were by that time priced at much higher levels reflecting netback from the European export market. ${ }^{143}$

The entry of China into the Central Asian gas trade and the construction of the TurkmenistanChina pipeline has provided Kazakhstan with opportunities to diversify away from Uzbek imports and secure more reliable supplies for the south-east of the country. After the completion of the Turkmenistan-China pipeline in December 2009, Kaztransgaz began construction of three links between that line and the BGR-TBA line. The first of these, at Uzynagash near Almaty, was completed rapidly, by November 2010, providing a route for Turkmen gas to reach Almaty, Kazakhstan's second city and usually the most severely affected by peak season reductions of Uzbek imports. Two more links between the two pipelines, at Akbulak in South Kazakhstan and Akyrtobe in Zhambyl, are under construction and due for completion by the end of 2012. Kaztransgaz has stated that the links will make it possible to use the Turkmenistan-China pipeline "as an alternative means of meeting gas demand and to ensure stability in the region". ${ }^{44}$

In November 2011, when supply from Uzbekistan was interrupted for a longer stretch than in previous years, arrangements were made with Turkmenistan and CNPC to receive Turkmen gas on a swap basis to supply customers in Almaty, presumably through the new link. In September 2012 Sauat Mynbayev, the Kazakh oil and gas minister, announced that a similar swap arrangement would be made to cover the 2012-13 heating season, and that negotiations were in progress with Turkmenistan, CNPC and Gazprom on the contractual details. ${ }^{145}$

The next stage of Kazakh diversification from Uzbek imports will be completion of the Beineu-Shimkent pipeline, which will bring gas from western Kazakhstan's producing fields to the south-east region, as well as potentially for export to China (see section 5.2).

\section{Tajikistan}

Uzbekistan has since Soviet times supplied Tajikistan with small volumes of gas (around 0.6 $\mathrm{bcm} /$ year up to the mid 2000s), as part of a complex swap arrangement, under which Tajikistan supplied in return water (for irrigation in the Ferghana valley region), electricity and transit services. Uzbekistan is the monopoly supplier and the only gas pipeline into Tajikistan comes from Uzbekistan; although Tajikistan's power is generated primarily from hydro plants, three of its largest industrial enterprises - its aluminium smelter, cement plant and nitrogen fertiliser plant - are dependent on imported Uzbek gas.

Since 2007 Uzbekistan has raised the price of its exports in line with European netback price levels, and gas exports to Tajikistan have been frequently interrupted on the grounds of nonpayment. This is not primarily a gas dispute, however: political and diplomatic relations between the two countries have deteriorated significantly in recent years. Uzbekistan is fiercely opposed to Tajikistan's plans to construct a dam at Rogun on the Vakhsh river. This

\footnotetext{
${ }^{143}$ Zhukov (2009), p. 371, and Yenikeyeff (2009), pp. 336-337; Kazmunaigaz, Godovoi otchet 2010, "Kratkaia informatsiia"; Kazmunaigaz, Godovoi otchet 2009, p. 35

${ }^{144}$ Kazmunaigaz press release, 30 November 2010; "Novaia peremychka pozvolit bespereboino obespechivat' gazom iuzhnye regiony", Meta.kz, 30 November 2010

145 "Postavki uzbekskogo gaza v Kazakhstan sushchestvenno snizheny”, Ferghana News, 15 November 2011 $<$ http://www.fergananews.com/news.php?id=17629>; "Iug Kazakhstana pereidet na turkmenskii gaz", Nur.Kz 14 November $2011<$ http://news.nur.kz/200885.html>; "Kazakhstan mulling gas imports from Turkmenistan", Tengri News service, 8 May2012; "Kazakhstan vernet gaz Turkmenii i zaimet ego u Rossii, Kitaia i Uzbekistana", Regnum.ru news agency, 15 September 2012
} 
would boost Tajikistan's economy by producing electricity for export, but also give Tajikistan undue influence over irrigation of the Ferghana valley, which is heavily dependent on the Vakhsh, which runs into the Amu Darya river, one of Uzbekistan's main sources of irrigation water. After an unsuccessful attempt by Russia to mediate the dispute in 2010, the Uzbek and Tajik governments issued hostile statements against each other, with the Tajik embassy in Moscow blaming Uzbekistan in April 2012 for trying to "blockade" Tajikistan, not only in respect of gas but also rail and road transport. ${ }^{146}$

Against this background, in 2009, Uzbekistan increased export prices to Tajikistan to $\$ 240 / \mathrm{mcm}$ from $\$ 150 / \mathrm{mcm}$; only $0.21 \mathrm{bcm}$ of a contracted $0.5 \mathrm{bcm}$ was delivered in that year due to interruptions for non-payment. In 2010 , only $0.25 \mathrm{bcm}$ was delivered and in 2011, 0.17 bcm. $^{147}$ In 2012, a contract for 0.2 bcm was agreed for the year. In March 2012, Uzbekneftegaz announced that it would stop supplying Tajikistan in order to have gas available for export to China. Tajikistan reported extensive power cuts, and said that it was aiming to secure gas supplies, presumably swaps, from Turkmenistan; in August, Turkmen president Gurbanguly Berdymukhammedov and Tajik president Emomali Rakhmon met and discussed (but did not finalise) arrangements for imports of both oil and gas; Tajikistan also entered into discussions with Iran about fuel imports. Rakhmon directed that all industry should make arrangements to use coal rather than gas as fuel, and coal production was increased. $^{148}$

\section{Kyrgyzstan}

Kyrgyzstan has traditionally imported a small quantity of gas from Uzbekistan, about 0.7 $\mathrm{bcm} /$ year up to the mid 2000s. Like Tajikistan, it inherited this arrangement from the Soviet era, when the gas was effectively paid for with electricity and water supplies. Like Tajikistan, Kyrgyzstan has plans to build dams that could exacerbate Uzbekistan's water problems, albeit not as far advanced as Tajikistan's. While political and diplomatic relationships have not deteriorated as sharply as in the case of Tajikistan, they are poor, and were exacerbated by inter-ethnic violence in southern Kyrgyzstan in 2010 which resulted in a flow of ethnic Uzbek refugees into Uzbekistan.

Uzbekistan's pricing policy towards Kyrgyzstan has been the same as towards Tajikistan, and it increased prices from $\$ 100 / \mathrm{mcm}$ in 2007 to $\$ 145 / \mathrm{mcm}$ in 2008 and $\$ 240 / \mathrm{mcm}$ in 2009 . Kyrgyzstan's main strategy in response has been to secure gas imports from Kazakhstan. Kyrgyzstan is better placed than Tajikistan to diversify, in terms of infrastructure: the BGRTBA pipeline arrives in the north of the country via Kazakh territory. Kyrgyz imports from Kazakhstan began in September 2011, when it contracted to buy $0.3 \mathrm{bcm}$ for the 2011-12 heating season, priced at $\$ 195 / \mathrm{mcm}$, a discount to the Uzbek price of $\$ 305 / \mathrm{mcm}$ in 2011 . In

\footnotetext{
${ }^{146}$ Farkhod Tolipov, "Uzbekistan-Tajikistan relations in limbo", Central Asia-Caucasus Analyst, 16 May 2012. On the background to Uzbek-Tajik relations, see e.g. Alexander Sodiqov, "The Rogun Dam controversy: is compromise possible", Central Asia-Caucasus Analyst, 2 May 2012, and Johannes Linn, "Central Asia: longterm challenges and short-term crises", International Water Power \& Dam Construction, March 2009, pp. 1417.

147 “Uzbekistan vdvoe urezal postavki gaza Tadzhikistanu”, Itar-Tass, 1 January 2011; “'Ob”"em exporta uzbekskogo gaza", Tsentraziia 9 January 2009; industry sources.

148 "Uzbekistan vozobnovil postavki gaz v Tadzhikistan", Kursiv, 16 April 2012; "V Tadzhikistane snizilsia import gaza, no uvelichilas' dobycha uglia", pressa. tj <www.pressa.tj/tj/print/13950>; British embassy, Updates on the Energy Sector of Turkmenistan, March 2012; "Iran budet eksportirovat' gaz", Kursiv, 2 May 2012
} 
2012, Kaztransgaz and Kyrgyzgas announced that they were discussing a contract for 0.3 bcm of imports in 2013. ${ }^{149}$

\section{Conclusion}

It seems likely that in the next few years, gas demand in the heavily populated areas of southeastern Kazakhstan may well continue to rise, but it will increasingly be met from non-Uzbek supplies. Uzbek exports to Kazakhstan will be mostly or completely replaced by swapped gas from Turkmenistan, delivered via the Turkmenistan-China pipeline, and then by gas from western Kazakhstan, delivered via the Beineu-Shimkent pipeline. Uzbek exports to Kyrgyzstan may also be reduced to a minimal level as Kazakh sales to Kyrgyzstan increase, while Uzbek exports to Tajikistan are likely to be halted altogether, and replaced with minimal volumes of swapped gas from Turkmenistan. Over a longer period, i.e. into the 2020s, demand for gas from both Tajikistan and Kyrgyzstan is likely to fall still further, as power generation requirements are covered by hydro and other supply diversification measures take effect.

\subsection{Gas consumption in Azerbaijan, Georgia and Armenia}

Azerbaijan has consumed between 7.0 and $10.5 \mathrm{bcm}$ of gas each year throughout the 2000s. In 2007, with the start-up of production at Shah Deniz, Azerbaijan became a net exporter, stopped importing gas from Russia and has since then supplied the domestic market from its own resources. About $50 \%$ of gas consumed goes into power generation; $2-3 \mathrm{bcm} /$ year in recent years has been consumed by residential customers; the petrochemical sector and other industry have consumed about $1 \mathrm{bcm} /$ year each.

Azerigaz, a Socar subsidiary, carries out natural gas processing, transport, distribution and storage in the domestic market. Government policy is to expand gas consumption further: Azerigaz is carrying out a range of construction and repair work, under the State Programme of Social Economic Development of Regions for 2009-2013, to gasify regions that are currently not supplied to the network. Socar reported that in $2010,4,250 \mathrm{~km}$ of new pipe was laid and $1,180 \mathrm{~km}$ repaired, and 67,272 subscribers' gas supply was restored. ${ }^{150}$ The government is also supporting projects designed to use Azerbaijan's natural gas resources to stimulate industrial development: a methanol plant is under construction, and in 2012 a tender process was underway for construction of a large fertiliser plant to supply the Azeri and Georgian markets. Azerbaijan implemented a sharp increase in the price of gas for domestic consumers in 2007 , to about $\$ 115 / \mathrm{mcm}$. Although further increases were envisaged at that time, prices have since remained at that level. Socar states that no further increases are planned in the near future. ${ }^{151}$ The combination of policies under which domesticallyproduced gas is used to stimulate industrial development on the one hand, but relatively high sales prices on the other, suggests that while consumption will continue to rise, it will probably do so less dramatically than in other countries in the region.

Georgia consumes 1-2 bcm/year of gas, almost all of it imported from Azerbaijan. (See also section 5.5 below.) Socar is also now a leading player in gas distribution in Georgia. Until the

\footnotetext{
149 "Peregovory o postavke kazakhstanskogo prirodnogo gaza", Kursiv, 8 Aug 2012; Kyrgyzgas press release, 8 May 2012; "Kazakhstan postavliaet Kyrgyzstanu gaz”, Fergana.ru, 28 September 2011; “Kazakhs ready to sell gas to Kyrgyz", RFE-RL, 20 Sep 2011

${ }^{150}$ Socar, Annual Report 2010, p. 29.

${ }^{151}$ Author's meetings with Socar representatives, Baku, May 2012
} 
late 2000s, Georgia's main source of imported gas was Russia; as a result of the deteriorating political relationship between those countries, Georgia has sought to reduce gas consumption e.g. by raising hydropower production.

Armenia consumes 2-2.5 bcm/year of gas: this is almost all imported from Russia, and does not therefore impact on market dynamics in the rest of the Central Asian/Caspian region. (There is more information about the Azeri, Georgian and Armenian markets in other publications by the OIES natural gas research programme. ${ }^{152}$ )

${ }^{152}$ See the chapters on these countries in Pirani (ed.) (2009), and Henderson, Pirani and Yafimava (2012), pp. 210-212. 


\section{Export routes and markets}

In the early and mid 2000s, the volume of gas exported from Central Asia (by Turkmenistan, Uzbekistan and Kazakhstan) rose steadily, from around $45 \mathrm{bcm} /$ year to $75 \mathrm{bcm} /$ year. More than $85 \%$ of this gas went to or through Russia; large-scale flows that began in Soviet times but had been disrupted during the 1990s slump were revived. The remainder were the small volumes (5-8 bcm/year) exported from Turkmenistan to Iran. In 2009-10 came two fundamental changes. First, Russia slashed its purchases from Turkmenistan as it struggled to deal with the recession and the consequent over-supply. Second, Turkmenistan began exporting gas to China: these flows were about $20 \mathrm{bcm} /$ year at the time of writing and will grow to two or three times that level. The third big change in recent years is the start-up of Azeri exports. After the Shah Deniz field started producing in 2006, Azerbaijan began exporting small volumes to Georgia and Turkey; these flows will increase, and some will reach Europe, in the coming years. But hopes of bringing large volumes of Caspian gas to Europe have not yet been realised, and plans to build infrastructure to take Turkmen gas to south Asia remain on paper. This section will (i) cover the current export of Central Asian and Caspian gas into Russia/FSU, Chinese, Iranian and Turkish markets, (ii) discuss the implications of changes in demand and pricing in those markets, and (iii) assess past setbacks, and future prospects, for other export routes.

\subsection{Exports to Russia, Ukraine and westwards}

During the 2000s, the Central Asian gas export trade to Russia recovered from the instability of the 1990s, against a background of Russian economic recovery, European economic growth, rising oil prices, and rising prices of gas (both Russian and Central Asian) sold into Europe on long-term, oil-linked contracts. ${ }^{153}$ The way in which this trade evolved reflected the specific circumstances of post-Soviet transition. In the oil and oil products markets, Kazakhstan, Turkmenistan and Azerbaijan had already gone a long way in diversifying their sales away from Russia and other former Soviet trading partners. Gas exports were however constrained by the transport infrastructure, built in Soviet times, which took all gas from the region to Russia, (i) via the Central Asia-Centre pipeline corridor towards central Russia and Ukraine, (ii) via the Orenburg processing plant to the southern Urals, and (iii) via the Bukhara-Urals pipeline to the Urals. (The only other pipelines from the Central Asian countries were the small-volume links from Turkmenistan and Azerbaijan to northern Iran, and links between Afghanistan and Turkmenistan that had been used to import gas to the Soviet Union but had fallen into disuse.)

The system that had taken shape in the 1990s was that Gazprom, having inherited most of the Soviet Union's gas sector assets, acted as a monopsonistic buyer of Central Asian exports and added them to its gas balance. This balance then satisfied three sources of demand: Russian domestic consumers, the western CIS gas importers (Ukraine, Belarus and Moldova) and the European market, to which Gazprom exported 130-170 bcm/year during the 2000s. Market forces played only an indirect role in determining prices. Gazprom's exports to Europe were sold on long-term contracts with prices linked to those of oil products, a system established in Soviet times that persisted until the end of the 2000s (although it is now undergoing substantial change, and may give way to a gas-to-gas market system, in the 2010s). These export prices were many times higher than the prices paid both by Russian domestic consumers and by the western CIS importers (prices for which were set, usually annually, in

\footnotetext{
${ }^{153}$ More detail on the 1990s and early 2000s, may be found in Henderson, Pirani and Yafimava (2012.), and in the relevant chapters of Pirani (ed.) (2009).
} 
politically-influenced negotiations that moved gradually away from heavy discounts and barter deals). In the mid 2000s, exports to Europe accounted for less than one third of Gazprom's gas balance, but up to two thirds of its revenues.

In the period up to the 2008-09 recession, four factors may be said to have shaped the Central Asian export trade: (i) the rising demand for gas in all markets, which Gazprom struggled to meet, and which made it reliant on Central Asian imports; (ii) the high (oil linked) gas prices in Europe, to which the Central Asian producers hoped to achieve some indirect access; (iii) political considerations, according to which Russia hoped to use its monopsonistic position in the gas trade to maintain influence in Central Asia when economic links were in general being weakened; and (iv) constant tension between Gazprom and various trading companies over who would control Central Asian gas volumes, which - when sold in Ukraine or Europe, priced against Russian gas but free of 30\% Russian export duty - yielded a handsome margin. As a result of all these factors, Gazprom bought all Central Asia's export volumes at prices negotiated politically but linked indirectly to European netback levels. These prices and commercial arrangements developed as follows.

Turkmenistan was the source of most of the exported Central Asian gas. Up to 2005, much of this gas had been bought by traders at the Turkmen border, transported through Uzbekistan, Kazakhstan and Russia, and sold to Ukrainian entities (either the national oil and gas company, Naftogaz Ukrainy, or traders) under a variety of commercial arrangements. In 2005-06, as the Russian government took steps to control the gas trade more closely, it put an end to direct Turkmen-Ukrainian commercial relationships. In January 2006, after the first Russo-Ukrainian "gas war" when supplies to Ukraine were reduced for four days, agreements were made under which all westward Turkmen gas exports were bought at the Turkmen border by Gazprom's international trading division (then Gazprom Export).

In 2006-08, all these volumes (except for a small amount in 2007) were then resold to the trading company Rosukrenergo (owned $50 \%$ by Gazprom and $50 \%$ by the Ukrainian businessmen Dmitry Firtash and Ivan Fursin), which transported them and supplied them to Ukraine (where they comprised the largest component of Naftogaz Ukrainy's gas balance) and central Europe. During this period, European gas prices (which are linked to oil prices with a six- or nine-month time lag in contracts) were moving towards a peak, which they reached in the last quarter of 2008. The annually-negotiated Ukrainian import price moved up too, under the principle (agreed between Russia and Ukraine in 2006) that it should reflect netback from the European border price - although it took the second "gas war" of January 2009 , and the resulting new 11-year contract, to bring them up to, and in fact some way beyond, the European netback level. Finally, the annually-negotiated prices paid by Gazprom at the Turkmen border rose, as shown in Table 21.

Table 21: Prices of Westward Gas Exports, 2005-09

\begin{tabular}{|l|c|c|c|c|c|}
\hline$\$ /$ mcm & 2005 & 2006 & 2007 & 2008 & 2009 \\
\hline European border price (est.)* $^{*} 213.70$ & 285.20 & 294.10 & 418.90 & 307.80 \\
\hline Ukrainian border price** & $50-80$ & 95 & 130 & 179.5 & 236.11 \\
\hline Turkmen border price & $44-60$ & 65 & 100 & $130-150$ & $340^{* * *}$ \\
\hline Uzbek border price & $42-64$ & $60-95$ & 100 & $130-160$ & 190 (est.) \\
\hline Kazakh border price & 47 & 100 (est.) & 100 (est.) & 180 & 180 (est.) \\
\hline
\end{tabular}

Source: information published by companies, press reports

* OIES estimates, based on published German import price and market information

** 2005-08 prices fixed annually; 2009 average, based on price adjusted quarterly

*** First quarter only. Westward exports suspended in q2-4. 
Table 21 shows that European border prices were rising so fast that, even while Russia shared some of this windfall with Turkmenistan, it also had at its disposal a widening margin between Turkmen border prices on one hand and both European and Ukrainian prices on the other. During the three years under which Rosukrenergo supervised this trade as shipper and supplier, the revenues it earned in Ukraine were probably minimal, due to payment delays and other risks. But it made substantial profits on the sales of the remaining Central Asian volumes (not only Turkmen but also Uzbek and Kazakh) in central Europe, where these were priced against Gazprom's Russian gas, on which 30\% Russian export duty had to be paid. ${ }^{154}$

Uzbekistan's westward exports were far smaller than Turkmenistan's, but rose steadily, from $4.9 \mathrm{bcm}$ in 2003 to $9 \mathrm{bcm}$ in 2006 and $12.4 \mathrm{bcm}$ in 2009. Prices also rose steadily, in close correlation with the prices achieved by Turkmenistan. In the early $2000 \mathrm{~s}$, Uzbek gas had been marketed in Ukraine by the Industrial Union of Donbass, and elsewhere in small quantities by other traders. Gazprom's efforts to centralise the gas trade made an impact here too. The agreements made after the January 2006 "gas war" provided for Gazprom Export to buy 7 bcm of Uzbek gas (and $8 \mathrm{bcm}$ of Kazakh gas), and for these volumes to be resold to Rosukrenergo. Alongside this arrangement, some Uzbek gas - including Gazprom's own volumes from the Gissarneftegaz and Shakhpakhty projects - was marketed by ZMB Schweiz, a subsidiary of Gazprom Germania, one of Gazprom's principal European marketing companies. (ZMB Schweiz marketed $6.4 \mathrm{bcm}$ of Uzbek gas in 2007 and $11.5 \mathrm{bcm}$ in 2008; some of this may have been repurchased from Rosukrenergo.) ${ }^{155}$

Kazakhstan's exports to and through Russia were at a slightly lower level than Uzbekistan's, and some of the gas was swapped for Russian gas delivered to Kaztransgaz customers in the Caucasus. Information on volumes up to 2005 are not available; in 2005-08 exports rose steadily from $7.8 \mathrm{bcm}$ to $10 \mathrm{bcm}$. The prices paid were not made public, but reported prices were correlated with those paid to Turkmenistan and Uzbekistan. The marketing arrangements for Kazakh gas also changed, and some flows were brought under the control of Kazrosgaz, the joint venture between Gazprom and Kazmunaigaz, established in 2002 to handle the export of Kazakh volumes to Orenburg for reprocessing and re-import. In May 2007, Kazrosgaz signed a 15-year export contract with Gazprom Germania, for the sale of gas at Aleksandrov Gai on the border of Russia and Kazakhstan. Kazrosgaz's principal counter-parties were Gazprom Germania and ZMB (Schweiz) (now Gazprom Schweiz). It may be presumed that the agreement made in 2006, to resell Kazakh gas to Rosukrenergo, stood until 2008, in which case Gazprom's side of it may have been kept by Gazprom Germania. $^{156}$

While the disposal of the trading margin on Central Asian gas, and the disputes between Russia and Ukraine over import contracts, have both been the subject of much public discussion, a neglected aspect of this episode is the way that Gazprom - no doubt under the influence of the Russian government, its main shareholder - shared some of the benefits of rising gas prices in Europe with its Central Asian suppliers. In May 2006, against a background of rapidly rising European gas prices, the price paid for Kazakh exports was reportedly raised substantially as the direct result of political intervention. Vladimir Putin, then prime minister, met with Kazakh president Nursultan Nazarbayev and shortly afterwards

\footnotetext{
${ }^{154}$ For more details, see e.g. Pirani, Stern and Yafimava (2010), and the relevant chapters of Pirani (ed.) 2009.

${ }^{155}$ ZMB (Schweiz) Annual Report 2007, p. 70; Annual Report 2008, p. 20.

${ }^{156}$ Kazrosgaz web site, "Eksport gaza" page
} 
secured agreement with Gazprom to triple the price it was paying. ${ }^{157}$ In March 2008, as the oil boom was reaching its apex, and Russia and Ukraine were once again at loggerheads over gas supplies and transit, the chief executives of Gazprom and the three Central Asian producer companies (Turkmengaz, Uzbekneftegaz and Kazmunaigaz) met in Moscow and agreed that Russia would in future pay "European prices", i.e. presumably netback from European prices, for Central Asian imports. A statement by Gazprom indicated that the agreement was made "considering the interests of the national economies and taking into account international conditions with regard to reliable and uninterrupted fuel supplies". ${ }^{158}$ Three months later, in June 2008, Gazprom CEO Aleksei Miller visited Ashgabat and signed a new agreement with Turkmengaz; reportedly, it provided for purchase prices to $\$ 225$ $295 / \mathrm{mcm}$ in the second half of the year, from the $\$ 130-150 / \mathrm{mcm}$ paid previously. ${ }^{159}$

\section{The 2009 crisis}

The dispute between Russia and Turkmenistan in 2009, and the sharp reduction in Russian purchases, was caused by a combination of the collapse of demand in Russian and European markets and extremely high purchase prices. Gazprom has stated that in 2008-09 its Central Asian purchase prices were tied to those in Europe; this may have meant a link to the prices in Gazprom's European export contracts, most of which are designed to reflect oil prices with a six- or nine-month time lag. With oil prices reaching their peak in mid 2008, it is probable that Gazprom's Central Asian purchase prices reached their peak in early 2009. This was the very point at which European and FSU gas demand was crashing, due to the economic recession. The best indication available of the price of Turkmen gas in the first quarter of 2009 is a statement by then prime minister Putin, implying that it was $\$ 340 / \mathrm{mcm}$; other reports suggested it was above $\$ 300 / \mathrm{mcm}$, and may have been as high as $\$ 375.50 / \mathrm{mcm}$. ${ }^{160} \mathrm{In}$ any case, the combination of such high purchase prices and the lack of demand was regarded by Gazprom as unsustainable, and purchases were summarily halted in April 2009.

The cessation of Russian purchases from Turkmenistan followed an accident on the Central Asia-Centre pipeline system on 9 April 2009 that was the subject of recriminations by Turkmen officials against Gazprom. There was an explosion at the SATs-4 compressor station; subsequently Odek Odekov, a senior Turkmen official (head of Turkmengeologia), said that a valve had been closed without Turkmen engineers' knowledge, "producing a socalled vacuum bomb effect". The valve closure stopped gas flowing along the main export route, and only one day's notice was given when three is required to take adequate remedial action, Odekov said. Turkmen officials stated that 195 production wells had been closed in as a result of the accident. Whatever the cause of the explosion, what is not disputed is that (i) all Turkmen export flows ceased as a result, (ii) the compressor station was repaired within a few days, and (iii) afterwards, Gazprom unilaterally decided not to restart imports. Although the terms of Gazprom's contract with Turkmengaz are not known, Odekov said that Turkmenistan had not ruled out international arbitration, suggesting (as seems logical) that

\footnotetext{
${ }^{157}$ Iiulia Sinchuk, "Gazprom dal Kazakhstanu evropeiskuiu tsenu”, Kommersant, 22 May 2009. This is an interview with Uzbakbai Karabalin, president of Kazmunaigaz, who implicitly confirmed that Kazakh export prices had risen to $\$ 140 / \mathrm{mcm}$ in 2006 from $\$ 47 / \mathrm{mcm}$ in 2005 . Other industry information suggests that the price rise was to $\$ 100 / \mathrm{mcm}$ (see Table 21 ).

158 “Ob itogakh rabochei vstrechi”, Gazprom press release, 11 March 2008; "Sredneaziatskii gaz - po evropeiskim tsenam”, Interfax, 11 March 2008

159 The prices were not disclosed, and are estimated on the basis of press reports. "Sergei Ivanov proshchupaet uzbekskuiu pochvu", Kommersant, 25 August 2008

${ }^{160}$ ICIS Heren, European Gas Markets, 17 December 2009; “Rossiia i Turkmenistan: okonchilas' li 'gazovaya voina'?", Kazenergy, January 2010, pp. 22-23.
} 
the cessation of purchases had breached contractual terms. Shortly after the accident Valerii Golubov, Gazprom deputy CEO, stated that the Gazprom had asked Turkmenistan to reduce volumes or prices, that "there is nowhere to sell your gas, at that price, today: either we reconsider the price, or the volume". ${ }^{161}$

With the benefit of hindsight it is clear that during this incident Gazprom's hand was forced by the consequences of the economic recession. In 2009 gas consumption in Russia was about 6\% lower than in 2008; in Ukraine, previously the main destination (at least contractually) for Turkmen gas, it was about 21\% lower; and in Europe, about 5\% lower. Having at the height of the oil boom agreed to share the benefits of high European prices with the Central Asian suppliers, Gazprom suddenly found itself unable even to handle physically the quantities of gas it had agreed to offtake. Its own production, as well as Turkmenistan's, was being shut in. And it was embarking on a major dispute with its largest European customers, who, believing that the differential opened up between oil-linked prices and gasto-gas market prices by the recession would remain for the medium term, demanded the renegotiation of contracts.

Commercially, the cessation of purchases from Turkmenistan in 2009 could only have been damaging for Gazprom; politically, only damaging for Russia. It must have confirmed fears in Ashgabat that Russia was potentially an unreliable partner. It surely redoubled Turkmenistan's determination to develop its multi-vector foreign policy in general and its relationship with China it particular. This is a significant conclusion, because it contradicts the widely held interpretation of Russia's decisions on natural gas trading issues as the use of an "energy weapon". Here, Russia's decisions showed its weakness: confronted by the economic crisis, the gas demand slump and the consequent loss of revenues, it chose to breach agreements with Turkmenistan as the least damaging option, but nevertheless an option that undermined its own foreign policy aim of retaining strategic influence in Central Asia. $^{162}$

\section{Westward export arrangements from 2009}

In December 2009, after an eight-month suspension of imports from Turkmenistan, addenda and amendments to sales contracts were signed by Gazprom Export and Turkmengaz, providing for sales to be resumed from 1 January 2010. Gazprom stated that the price formula was "indexed to correlate with changes in the prices of oil products" (i.e. reflecting the price levels at which Gazprom was selling into Europe). ${ }^{163}$ The agreement provided for Turkmengaz to sell up to $30 \mathrm{bcm} /$ year to Gazprom, but it was stated by both sides that exports would be 10-11 bcm/year for the foreseeable future. Price levels were not made public, but Gazprom management price forecasts, reported in Moscow, were for purchases in 2010 from Turkmenistan at $\$ 222 / \mathrm{mcm}$, Kazakhstan at $\$ 230 / \mathrm{mcm}$ and from Azerbaijan at $\$ 244.50 / \mathrm{mcm}$. In the event, Gazprom's purchase prices were lower than that: the company's annual reports gave the average price of its purchases of gas from Central Asia and Azerbaijan as \$197.20/mcm in 2010 (down from $\$ 233.55$ in 2009) and $\$ 244 / \mathrm{mcm}$ in 2011. ${ }^{164}$

\footnotetext{
${ }^{161}$ Aleksandr Tutushkin, "Vygodnaia avariia", Vedomosti, 10 April 2009; "Turkmeniia ostanovila dobychu na 195 skvazhinakh”, Vzglyad.ru, 29 May; “Gazoprovod 'Turkmeniya' gotov k vozobnobleniiu podachi gaza”, Vzglyad.ru, 29 May 2009; Upstream, 26 June 2009.

${ }^{162}$ See also Simon Pirani, "Russian gas: the next ten years", Oxford Energy Forum, August 2012, p. 12.

${ }^{163}$ Gazprom web site, "Zakupki gaza" page < http://www.gazprom.ru/about/production/central-asia/>

${ }^{164}$ Gazprom, Annual Report 2011, p. 80; Geller( 2011), quoting Gazprom presentation Gaining Momentum.
} 
The volumes and prices of Gazprom's purchases from Kazakhstan and Uzbekistan remained essentially unchanged through the 2009 crisis. In 2010 Gazprom reported purchases of 12.4 bcm from Kazakhstan and of $11.4 \mathrm{bcm}$ from Uzbekistan (respectively, up from $10.1 \mathrm{bcm}$ in 2009 and down from $13.1 \mathrm{bcm}$ in 2009). There is only patchy information about prices and contract terms. In the case of Uzbekistan, Gazprom has stated that in December 2009 it signed contracts with Uztransgaz for the purchase of a total of $15.5 \mathrm{bcm}$ in 2010, an increase of $4.25 \mathrm{bcm}$ on the volumes agreed upon earlier; prices would be linked by a formula to average European prices. In a subsequent presentation, Gazprom indicated that purchases from Uzbekistan would be $17.2 \mathrm{bcm}$ in $2010 .{ }^{165}$ As it turned out, in 2010 , only $11.4 \mathrm{bcm}$ was delivered, and in 2011, only $8 \mathrm{bcm}$. Gazprom managers told journalists in Moscow that this was as a result of the Uzbek supply squeeze discussed in section 4.1 above. It is significant that both the long-term contracts agreed in 2002 between Gazprom and Uzbekneftegaz, and the supplementary agreements made in 2010, expire at the end of 2012. This could be a turning-point at which the gas trading relationship between Russia and Uzbekistan is further reduced.

In the case of Kazakhstan, there were also discussions about adjusting prices and contract terms during 2009. No information is available on the terms agreed. Kazmunaigaz has stated that Kazrosgaz, its joint venture with Gazprom, exports gas that it has purchased (i) under a 15-year sales agreement with the Karachaganak project, starting in 2007, and (ii) from the Tengiz field, on terms that are not specified. Kazrosgaz stated that it exported only $2.9 \mathrm{bcm}$ of gas in 2010, According to press reports, in 2009 Gazprom with its Kazakh counterparts agreed to buy $10-15 \mathrm{bcm} /$ year at European-linked prices and a further $3 \mathrm{bcm} /$ year at prices related to those in Ukraine. ${ }^{166}$

The commercial arrangements for the westward export of Central Asian gas also changed in 2009. Up until the end of 2008, most volumes were purchased from the Central Asian suppliers by Gazprom Export and resold to Rosukrenergo, which acted as shipper and supplier. As a result of the January 2009 "gas war" between Russia and Ukraine and the new contractual arrangements made between them, Rosukrenergo's role as a purchaser and reseller of Central Asian gas ceased. From March 2009, Gazprom Germania, Gazprom's wholly-owned trading subsidy based in Germany, has purchased all westward-bound gas from Central Asia on Gazprom group's behalf, transported it to Ukraine, Belarus, Georgia and western Europe and transferred it to Gazpromexport for onward sale. ${ }^{167}$ The trading margin on Central Asian volumes remains high because although there are additional transport costs to pay, they are priced against volumes from Russia that incur $30 \%$ export duty. There is no comprehensive information on the destination of the gas. ${ }^{168}$ The traditional sale of Central Asian volumes to Ukraine continues: in 2011, in addition to purchases by Naftogaz Ukrainy, there were purchases of $4.8 \mathrm{bcm}$ by Ostchem Holding, a holding company that dominates the Ukrainian chemical fertiliser sector and is controlled by Dmitry Firtash,

\footnotetext{
${ }^{165}$ Gazprom investor day presentation, Gaining Momentum, February 2010; Gazprom press release 28 December 2009; Gazprom web site, "Zakupki gaza" page

${ }^{166}$ Kazmunaigaz Godovoi Otchet 2010, p. 32; Iiulia Sinchuk, "Gazprom dal Kazakhstanu evropeiskuiu tsenu”, Kommersant, 22 May 2009.

${ }^{167}$ Gazprom Germania Annual Report 2010,pp. 13-14. There is an anomaly with regard to volumes. Gazprom Germania states that its Central Asian trading volumes were $32 \mathrm{bcm}$ in 2009 and $38 \mathrm{bcm}$ in 2010, while Gazprom group states that its Central Asian trading volumes were $35 \mathrm{bcm}$ in 2009 and $34.5 \mathrm{bcm}$ in 2010. It appears that in $2009,3 \mathrm{bcm}$ were traded under previous arrangements. There is no obvious reason for the disparity between the figures given for 2010 .

${ }^{168}$ Physically, the volumes are added to the Russian gas balance in the Russian united transport system. Contractually, they are treated as exports to Ukraine and other destinations.
} 
part-owner of Rosukrenergo. It is presumed that Gazpromexport sells most of the remaining volumes of Central Asian gas mostly in European markets.

The momentous changes in the European gas market (transition away from oil-linked pricing to gas-to-gas hub-based pricing) and in the Russian market (transition towards higher prices and away from Gazprom quasi-monopoly) imply changes for Central Asia's westward exports. This is discussed below in section 5.3.

\subsection{Exports to China}

The start-up in 2010 of Central Asian gas exports to China was the result of a strategic policy initiative by the Chinese government, which made agreements with the three Central Asian producing countries to construct the Turkmenistan-China pipeline and to bring Chinese companies into upstream production. China's move into the gas sector followed its substantial investment in the Kazakh oil sector, and growth of its economic and trading activity throughout Central Asia. Exports of Turkmen gas through the pipeline are now running at about $20 \mathrm{bcm} /$ year; there seems little doubt that the volumes exported will rise to $30 \mathrm{bcm} /$ year by 2015 (the capacity of lines A and B of the Turkmenistan-China pipeline, which are completed) and to as much as $55 \mathrm{bcm} /$ year in the second half of the decade (including line $\mathrm{C}$, which is under construction). Kazakhstan could add 5-10 bcm to this; Uzbekistan has a framework agreement to supply $10 \mathrm{bcm}$ but may be constrained by upstream issues and its own consumption requirements. But there is little doubt that China will be able to source these volumes from Turkmenistan, even if the timetable of South Yolotan and other fields coming on stream may be revised.

\section{The Turkmenistan-China pipeline}

The Turkmenistan-China pipeline comprises: Line A $(1,067 \mathrm{~mm})$, commissioned in December 2009; Line B (1,067 mm), commissioned in July 2010; and Line C, which is under construction, and due to be completed by 2015. In Turkmenistan, the pipelines run from the Bagtyiarlyk compressor station to the Uzbek border. The Uzbek section is $529 \mathrm{~km}$ long and is operated by Asia Transgaz, a CNPC-Uzbekneftegaz joint venture. The Kazakh section is $1,308 \mathrm{~km}$ long; work on it has been completed under an agreement between Kazmunaigaz and CNPC; construction was by Aziatskii gazoprovod, a joint venture between Kazntransgaz and Trans Asia Gas Pipeline Ltd, a CNPC subsidiary. The capacity of Lines A and B has risen in stages as compressor stations have been added in Uzbekistan and Kazakhstan; according to company information, the capacity was under $17 \mathrm{bcm} /$ year at the end of 2010 , and after the completion of compressor stations nos. 1, 4 and 6 in Uzbekistan in 2011 had risen to $23 \mathrm{bcm} /$ year. The joint total capacity of lines $\mathrm{A}$ and $\mathrm{B}$ is projected to be 30 bcm/year. ${ }^{169}$

Two further expansions of the pipeline are currently planned. The first is the construction of line C, which will add a further $25 \mathrm{bcm} /$ year of capacity. In September 2011, agreements were signed respectively between CNPC and Uzbekneftegaz, and CNPC and Kazmunaigaz, on the construction and operation of line $\mathrm{C}$ through Uzbekistan and Kazakhstan. The planned date of completion was reported as 2014. In April 2012 the agreement on the Uzbek section was complemented by a presidential decree that set out a timetable for construction to be

${ }^{169}$ CNPC web site, “Turkmenistan” and "Uzbekistan” pages; Kaztransgaz annual report 2010 
completed in $2015 .{ }^{170}$ The second expansion of the pipeline is for $10 \mathrm{bcm} /$ year of additional capacity to be added in Kazakhstan, in conjunction with the completion of the BeineuShimkent pipeline. ${ }^{171}$ This would presumably provide for flows of Kazakh gas to China although, as indicated below, there are some disagreements between Kazakhstan and China on the timing and scale of these projects.

\section{Turkmen exports to China and pricing issues}

The Turkmenistan-China pipeline began to be filled with linepack in December 2009. Exports have risen from about $3.5 \mathrm{bcm}$ in 2010, and $15.5 \mathrm{bcm}$ in 2010 to $20 \mathrm{bcm}$ in 2012 . (The information available about volumes is not consistent; these are estimates. See box below on Volumes of Central Asian exports to China.) So far, all the gas exported has been from Turkmenistan; if Uzbekistan has begun exporting gas at all, the volumes are negligible. The gas exported is (i) CNPC's own gas produced at Bagtyiarlyk, comprising about one-third of exports so far; ${ }^{172}$ and (ii) Turkmengaz production, mostly from Malay and the Uchadzi group of fields. The development plan agreed between China and Turkmenistan projects that the initial target of $30 \mathrm{bcm} /$ year will comprise $13 \mathrm{bcm} /$ year from CNPC's PSA (its projected peak output), and $17 \mathrm{bcm} /$ year from Turkmengaz. ${ }^{173}$

Turkmen gas is fed into the West-East Gas Pipeline Corridor at Horgos, in China's Xinjiang autonomous region on the Kazakh border, and transported eastwards. It has been supplied to south-central China and industrial regions of eastern China. Deliveries to south-central China began in December 2010, when CNPC announced that the Zhongwei-Huangpi trunk line of the eastern segment of the West-East Gas Pipeline had become operational ahead of schedule, and that Turkmen volumes were flowing to Hubei and Hunan, easing gas supply shortages. In June 2011, the 2,517 km eastern section of the pipeline, from Zhongwei to Guangzhou, was completed, together with a branch line from Guangzhou to Shenzhen, one of China's largest industrial concentrations. In November 2011, natural gas lighting ceremonies were held in both Shenzen and Guangzhou, as Turkmen gas arrived there for the first time. Gas is supplied to Shenzen under a sales agreement signed in 2010 between Shenzen Gas Corp and PetroChina for $4 \mathrm{bcm} /$ year. $^{174}$

\footnotetext{
${ }^{170}$ CNPC web site; “China, Kazakhstan agree Line C”, Platt's International Gas Report, 10 October 2011; presentation by Abdubakhram Vakilov, Asia Transgaz, at Oil and Gas Uzbekistan conference, May 2012, Tashkent

${ }^{171}$ Kazmunaingaz, Godovoi Otchet 2010, p. 36; Kaztransgaz Godovoi Otchet 2010, “Investitsionnaia deiatel'nost"'

${ }^{172}$ The cumulative output from CNPC's PSA was $10.5 \mathrm{bcm}$ up to mid 2012 (see section 3.1 above); cumulative exports up to mid 2012 were reported as $30 \mathrm{bcm}$ by the China Daily (see box).

${ }^{173}$ Bernstein Research, The Caspian: Cradle of Oil Production, p. 85

174 “China builds 2nd West-East line”, Platt's International Gas Report, 20 June 2011; “Turkmenistan Natural Gas Arrived in Guangdong”, SZ Energy, 28 November 2011.
} 


\section{Volumes of Central Asian exports to China}

For 2010, Cedigaz reported $3.55 \mathrm{bcm}$ of exports while Aziatskii gazoprovod, the Kazakh joint venture that operates the Kazakh section of the pipeline, said it had transported 4.4 bcm of gas during the year. In 2011, PetroChina said it had imported $15.5 \mathrm{bcm}$, while customs statistics showed that in June-December 2011, $6.7 \mathrm{bcm}$ was imported, suggesting either a lower level of imports or that the customs statistics excluded CNPC's own gas produced at Bagtyarlyk. In 2012, customs statistics showed $4.8 \mathrm{bcm}$ of imports during the first four months, suggesting that imports for the year (assuming a steady increase) will be $15-20 \mathrm{bcm}$; PetroChina announced that $24.1 \mathrm{bcm}$ of gas could be imported from Central Asia this year. Finally, the China Daily reported in June 2012 that total import via the pipeline up to that date was $30 \mathrm{bcm}$.

Sources: BMI, Turkmenistan Oil \& Gas Report Q1 2012, p. 5; Kaztransgaz Annual Report 2010,

"Osnovnye rezul'taty deiatel'nosti"; SZ Energy, "Turkmenistan takes growing share of China gas market", 13 June 2012; customs statistics; "China's imports of Turkmen gas since 2009 totals 30 bcm", Platts, 4 Jun 2012.

On a political level, there are intentions to increase Turkmen exports to China even further than the $40 \mathrm{bcm} /$ year of pipeline capacity in operation or under construction. The original agreement between the two countries, made in 2006, envisaged exports of $30 \mathrm{bcm} /$ year for 30 years after initial field and pipeline development, with an option on increasing volumes to 40 $\mathrm{bcm} /$ year. Since the exports began, the two sides have explored the possibility of expansion. In March 2011 the Chinese National Development and Reform Commission said that it had reached "consensus" on adding a further $20 \mathrm{bcm} /$ year to the initial $30 \mathrm{bcm} /$ year. And in November that year, Turkmen president Berdymukhammedov and Chinese president $\mathrm{Hu}$ Jintao signed a further agreement providing for increased exports and for further cooperation at South Yolotan. Berdymukhammedov stated after the meeting that Turkmenistan was ready to raise the volume of exports planned from $40 \mathrm{bcm} /$ year to $65 \mathrm{bcm} /$ year. ${ }^{175}$

Turkmen reserves are ample to meet demand at these levels. There are three possible constraints: (i) Given Turkmenistan's small population and the limits to its requirement for export revenues, Turkmen governments may be inclined to increase exports to China gradually, or to limit them at some stage (as argued above in section 2). (ii) Given the Turkmen government's apparent determination to limit the involvement of foreign companies (excluding the Chinese state-owned companies) in the upstream, and the country's limited supply of managerial experience and skilled labour, field development may take longer than anticipated. A lack of information makes it difficult to assess this constraint in more detail. (iii) The evolution of the Chinese gas market which, in line with government policy, is both expanding rapidly and moving away from fixed and regulated prices towards market mechanisms, ${ }^{176}$ may put in question the price formulas being used, which at present require CNPC, the importer, to bear a considerable loss on sales.

Chinese official sources have stated that prices in the Turkmen contracts are linked to oil prices. Details are confidential, but it is clear that Turkmen imports are substantially more expensive than domestically-produced Chinese gas, and, in the east of the country, even more

\footnotetext{
175 “China hits Turkmen landmark", Platt's International Gas Report, 6 June 2011; Robert Cutler, "Turkmenistan to raise gas exports to China", Asia Times, 30 November 2011, cited by InoZpress web site.

${ }^{176}$ For Chinese market and pricing issues, see Chen (2012), pp. 310-337.
} 
expensive than imported LNG - the price of which is relatively high by the standards of international gas markets. CNPC has stated publicly that it bears a loss on the sale of Turkmen gas. A comparison between the estimated price of Turkmen gas and other sources of supply at Shanghai - which has been selected by the Chinese regulatory authorities as a hub from which prices and transport fees will be calculated - is shown in Table 22.

Table 22: Shanghai Gas Prices, October 2011

\begin{tabular}{|l|r|r|}
\hline & $\$ / \mathrm{mmbtu}$ & $\$ / \mathrm{mcm}$ \\
\hline $\begin{array}{l}\text { Price of Turkmen gas at the Kazakh-Chinese } \\
\text { border (assuming an oil price of \$100/barrel) }\end{array}$ & 9.1 & 334.0 \\
\hline West-East Pipeline II transmission tariff & 4.2 & 154.1 \\
\hline Shanghai city gate (Turkmen gas) & 13.3 & 488.1 \\
\hline Shanghai city gate (Chinese domestic gas) & 9.8 & 359.7 \\
\hline Shanghai city gate (LNG from Malaysia)* & 7.5 & 275.2 \\
\hline $\begin{array}{l}\text { Loss borne by CNPC on sale of Turkmen gas (i.e. } \\
\text { price of Turkmen gas - price of domestic gas) }\end{array}$ & 3.5 & 128.4 \\
\hline $\begin{array}{l}\text { * There is a wide range of prices paid for LNG imports into China, with } \\
\text { the price of Malaysian LNG near the middle. Customs data for October } \\
\text { 2011 shows prices between \$3.24/mmbtu (Australian LNG) and \$19.18 } \\
\text { (Egyptian LNG) paid ex-ship, with re-gasification and transport costs to be } \\
\text { added. }\end{array}$ \\
\hline
\end{tabular}

Source: Michael Chen, OIES

Table 22 presents estimates of prices in October 2011, when oil prices were at around $\$ 100 /$ barrel. Both Turkmen gas prices and LNG prices move in correlation with oil prices. But the most important point highlighted by the table is that, in part due to the high cost of transportation across China, Turkmen gas is substantially more expensive than domestically produced gas when it arrives in eastern China. Whether and when this could become a problem depends on Chinese government policy.

China's decision to source gas from Central Asia was a matter of industrial strategy: upstream investments, the large-scale loan programme to Turkmenistan to fund its upstream investments, and pipeline construction, have been funded accordingly, through CNPC, a state-owned corporation, and the state banks. CNPC's trading losses on the sale of Turkmen gas may be borne in line with the same strategic considerations. However Chinese government policy also favours the development of a gas market. The National Development and Reform Commission (NDRC) has adopted a reform plan; the first important step was that in some areas a move away from the norm of regulated cost-plus prices, to a system of oillinked netback pricing, has been tested from November 2011. The eventual aim is to replace the large number of regulated prices with a unified city-gate price in each province and thereafter to "liberalise well-head prices and let the market decide the prices", in the words of the NDRC. ${ }^{177}$ There are many uncertainties over how quickly the reform will develop, to what extent the NDRC will allow prices to liberalise, and how the question of competition with coal, China's main fuel, will be handled. However, over the medium and long term, the course of this reform will be crucial to Central Asian exporters. To the extent that a market develops in China, Central Asian gas will compete in that market against other gas producers

${ }^{177}$ Quoted in Chen (2012) p. 327. 
and potentially against others fuels. If the substantial differential between the price of Central Asian gas and that of other gas persists, it could come under downward pressure from the market.

\section{Constraints on Uzbek and Kazakh exports to China}

China's initial agreement with Kazakhstan on the pipeline and gas exports was signed by CNPC and Kazmunaigaz executives in October 2008, with support from their respective governments, which followed a lengthy history of cooperation in the oil sector. Kazmunaigaz agreed to "take all necessary measures" to facilitate the export of $5 \mathrm{bcm} /$ year from CNPC's subsidiary, CNPC-Aktobemunaigaz, and a further 5-10 bcm/year from the Urikhtau field, which would be developed jointly; some Urikhtau gas would be supplied to south-eastern Kazakhstan; and the two sides jointly would build and operate the Beineu-Shimkent pipeline. ${ }^{178}$ Further agreements were signed on pipeline construction, and in February 2011 a new "oil and gas cooperation agreement" was signed by presidents Hu Jintao of China and Nursultan Nazarbayev of Kazakhstan, specifying that a 50-50 joint venture would be established by CNPC and Kazmunaigaz to develop Urikhtau. ${ }^{179}$

However, in contrast to the rapid construction and expansion of the Turkmenistan-China route, these agreements have been implemented slowly or not implemented. This appears to be because the two sides have not resolved differences about how the gas resources will be divided between them, including such issues as the funding of, and control over, production and transportation projects, and the allotment of gas to domestic and export markets.

The outward signs of tension between the two sides are: (i) The lack of movement towards the formation of a joint venture at Urikhtau, as provided for in agreements (see section 3.3 above), apparently due to Kazakhstan's desire to increase its own share of, and control over, the development of the field. (ii) Initial reluctance by China to agree to the Beineu-Shimkent pipeline project in the form proposed by Kazakhstan, and, since the agreement was made in mid 2010 to go ahead with the pipeline, disagreement over its financing. (It has been agreed that each partner would contribute $\$ 500$ million, and a further $\$ 2$ billion would be available in loans from Chinese banks). The source of some of this tension is reported to be the Kazakh side's insistence on measures to ensure maximum benefit to its gasification plans from the project (see section 4.3 above). (iii) Reported delays in the start-up of construction of the Kazakh section of Line $\mathrm{C}$ of the Turkmenistan-China pipeline, and a reported dispute over the level of transit tariffs to be set for that line. ${ }^{180}$

In June 2012, during a summit of the Shanghai Cooperation Organisation (SCO) in Beijing, a plan to build a pipeline from Turkmenistan, through northern Afghanistan and Tajikistan to China was reported in official Chinese media after meetings between Chinese president $\mathrm{Hu}$, CNPC chairman Jiang Jiemin and Afghan president Hamid Karzai. ${ }^{181}$ Although the announcement was interpreted as a means of cutting across US-supported plans for a pipeline from Turkmenistan across Afghanistan to south Asia (see below section 5.6), it may also have served as a reminder to Kazakhstan that there were potential export routes for Turkmen gas to China avoiding its territory.

\footnotetext{
${ }^{178}$ CNPC press release, 1 November 2008, "CNPC and KazMunayGas sign framework agreement"

${ }^{179}$ CNPC press release, "New oil and gas cooperation agreement”, 23 Feburary 2011

${ }^{180}$ PFC Energy, Kazakhstan: China Gas Route May Be Delayed, 30 July 2012

${ }^{181}$ Vladimir Socor, "Beijing Proposes Turkmenistan-China Gas Pipeline Through Northern Afghanistan", Eurasia Daily Monitor, 19 June 2012
} 
In the case of Uzbekistan, China's interest in the gas sector started in the upstream, where CNPC began work in 2006. In 2009, CNPC signed a series of agreements on cooperation in the energy sector with Uzbekneftegaz, and in 2010 came an intergovernmental memorandum of understanding and a framework agreement providing for the sale of $10 \mathrm{bcm} /$ year of gas to China. ${ }^{182}$ In contrast to Kazakhstan, where the terms on which to cooperate with China are still being decided, it appears that the difficulty in Uzbekistan will be in ensuring sufficient gas is available for export. In January 2012 Uzbek official media stated that gas exports to China would start in April, although no information on volumes was given. But in May 2012 it was reported that exports had not yet begun: an official of Uzbekneftegaz, cited by Reuters, said that exports could be $2-4 \mathrm{bcm}$ this year, but that legal issues still had to be resolved before they could begin. ${ }^{183}$

\subsection{Pricing and volumes: China versus westward export}

The establishment of China as a second main market for Central Asian gas raises the issue of how netbacks from sales in China compare to those of westward exports. Table 23 presents an attempted comparison. Netbacks have been estimated using the Chinese border prices in Table 22, and Ukrainian import prices extrapolated from customs information. Table 23 also compares the average price at which Gazprom buys gas in Central Asia with its gas sales prices to customers in two of the largest consuming regions (Moscow and Sverdlovsk) and two regions that border on Kazakhstan (Orenburg and Saratov).

\footnotetext{
${ }^{182}$ CNPC press release, “CNPC and Uzbekneftegaz sign agreements”, 1 July 2009; CNPC press release, "Natural gas purchase and sale framework agreement",, 10 June 2010

183 angi.ru, "Uzbekistan s 1 aprelia nachnet postavki gaza v Kitai”, 13 January 2012; Dmitry Solovev, "Uzbekistan aims to join China gas supply route", Reuters, 17 May 2012

<http://www.reuters.com/article/2012/05/17/gas-uzbekistan-china-idUSL5E8GHCR220120517>
} 
Table 23: Central Asian Gas Prices, 2011

\begin{tabular}{|c|c|c|c|}
\hline \multicolumn{4}{|c|}{ Average prices for the year } \\
\hline \multicolumn{4}{|c|}{$\begin{array}{l}\text { Prices in China and Ukraine: netbacks compared } \\
\text { (author's estimates) }\end{array}$} \\
\hline & & & $\$ / \mathbf{m c m}$ \\
\hline \multicolumn{3}{|c|}{ Turkmen gas at the Chinese border } & $285-290$ \\
\hline \multicolumn{3}{|c|}{ Turkmen gas at the Ukrainian border } & 355 \\
\hline \multicolumn{3}{|c|}{ Uzbek gas at the Ukrainian border } & 355 \\
\hline \multicolumn{3}{|c|}{ Kazakh gas at the Ukrainian border } & 351 \\
\hline \multicolumn{3}{|c|}{ Turkmen gas for China, netback to Turkmen border } & $241-247$ \\
\hline \multicolumn{3}{|c|}{ Turkmen gas for Ukraine, netback to Turkmen border } & 292 \\
\hline \multicolumn{3}{|c|}{ Uzbek gas for Ukraine, netback to Uzbek border } & 296 \\
\hline \multicolumn{3}{|c|}{ Kazakh gas for Ukraine, netback to Kazakh border } & 312 \\
\hline \multicolumn{3}{|c|}{$\begin{array}{l}\text { Gazprom average purchase price in Central Asia and } \\
\text { Azerbaijan }\end{array}$} & 240 \\
\hline \multicolumn{4}{|c|}{ Gazprom purchases and Russian domestic prices compared } \\
\hline & & $\mathbf{r} / \mathbf{m c m}$ & $\$ / \mathbf{m c m}$ \\
\hline \multicolumn{2}{|c|}{$\begin{array}{l}\text { Gazprom average purchase price in Central } \\
\text { Asia and Azerbaijan }\end{array}$} & & 240 \\
\hline \multicolumn{2}{|c|}{ Average wholesale price - industry } & 2850 & 95.00 \\
\hline \multicolumn{2}{|c|}{ Average wholesale price - population } & 2203 & 73.43 \\
\hline \multirow{4}{*}{$\begin{array}{l}\text { Regulated wholesale } \\
\text { price: industry }\end{array}$} & Moscow & 3071 & 102.37 \\
\hline & Sverdlovsk & 2588 & 86.27 \\
\hline & Orenburg & 2570 & 85.67 \\
\hline & Saratov & 2922 & 97.40 \\
\hline \multicolumn{2}{|c|}{$\begin{array}{l}\text { Netback from European border price to } \\
\text { Russian market (Federal Tariff Service } \\
\text { calculation)* }\end{array}$} & 7400 & 246.66 \\
\hline \multicolumn{4}{|c|}{$\begin{array}{l}\text { Assumptions. Exchange rate of } 30 \mathrm{r} . / \$ \text { used. I have assumed } \\
\text { transit fees of } \$ 3.50 / \mathrm{mcm} / 100 \mathrm{~km} \text { in Russia (my estimate), } \$ 2.50 \\
\text { in Kazakhstan (Kaztransgaz information), } \$ 2.10 \text { in Uzbekistan } \\
\text { (industry information) }\end{array}$} \\
\hline \multicolumn{4}{|c|}{ Note. Estimated netback prices rounded to nearest dollar } \\
\hline \multicolumn{4}{|c|}{$\begin{array}{l}\text { * This is for the fourth quarter of 2011. The FTS have not } \\
\text { published a figure for the whole year }\end{array}$} \\
\hline
\end{tabular}

Sources: Gazprom average purchase price: Gazprom annual report. Ukraine border prices: extrapolated from customs information "Ukraina v proshlom godu importirovala gaz na \$14 mlrd", Zerkalo Nedeli, 21 February 2012. All other international prices: author's estimates. Russian domestic prices: Federal Tariff Service web site.

The following conclusions are suggested by Table 23:

1. Despite the poor quality of information, it may be tentatively assumed that the netback received in Turkmenistan for exports to China is in the region of $\$ 50 / \mathrm{mcm}$ lower than the netback received for westward sales (for which the netback from Ukraine is a good indication) - i.e., in 2011 , around $\$ 241-247 / \mathrm{mcm}$ as opposed to $\$ 292 / \mathrm{mcm}$. It is possible that Turkmenistan has agreed to these lower prices in return for the major programme of economic and strategic support it is receiving from China. 
2. Even assuming that sales to China are priced with this type of discount to westward exports, Turkmen gas still struggles to compete with other Chinese imports after transport costs to southern and eastern China are taken into account.

3. In the case of exports to Ukraine, if my estimates of netbacks to the producer countries' borders (\$292/mcm, $\$ 296 / \mathrm{mcm}$ and $\$ 312 / \mathrm{mcm}$ in 2011) are even roughly correct, the fact that Gazprom's average purchase price in 2011 was $\$ 240 / \mathrm{mcm}$ implies that Gazprom earned a margin of $\$ 50 / \mathrm{mcm}$ or more, minus transport costs, on gas exported to Ukraine.

4. From Gazprom's point of view, buying Central Asian gas and selling it net of Russian export duty in Ukraine, at the high European-linked prices paid there, was a profitable exercise in 2011 and may be for some time yet. But the long-term prospects for this trade are less clear. The prevalence of oil-linked prices in the European market is in question. Ukrainian import prices were tied to a European-type oil-linked formula when negotiated in 2009 but, if and when European price formation changes, Ukrainian price formation may change too. Although Russia and Gazprom have robustly refused to renegotiate the Ukrainian import contracts so far, further fundamental shifts in the European market would weaken their negotiating position. Secondly, at long last the Ukrainian government has begun to react to high import prices by actively seeking to reduce consumption and to increase its own production. Such measures will take some years to make a fundamental difference to the gas balance, but they may start quite soon to reduce Ukraine's import requirement.

5. Central Asian gas exported westwards has been sold according to contract in Ukraine or central Europe, but physically goes into the Russian pipeline network and is probably swapped for Russia's own production. Should changes in the European and Russian market lead to Central Asian gas competing directly against Russia's own production in the Russian market, it would struggle to do so. Gazprom's average purchase price in Central Asia of $\$ 240 / \mathrm{mcm}$, low enough to assure it of a profitable margin on Ukrainian sales, is far too high to allow Central Asian gas to compete either in Russia's major industrial areas or even in the areas close to the Kazakh border at current prices. As the Russian market develops, domestic prices will rise - but they may never reach levels comparable to netback from oil-linked European prices. Over the medium and long term, therefore, Central Asian producers may face difficulty (i) in preserving the principle of netback from European oil-linked prices with which they have worked with Gazprom since 2008, as Gazprom itself may have to yield that principle in many respects; and (ii) in competing in the Russian market, which may become the main destination for their westward exports. If the Russian market remains oversupplied, as it has been in 2009-2012, there will be correspondingly less motivation for Gazprom or any Russian entity to import Turkmen gas to Russia, or to make arrangements for it to be exported to Ukraine.

The point about the medium- and long-term prospects for Central Asian sales into the Russian market is brought home forcefully by Figure 2, which shows estimates by the Moscow School of Management, Skolkovo Energy Centre of the comparative costs of gas supplied to central Russia in 2020. The most striking implication of the Figure is that even the most expensive Russian domestically-produced gas is likely to be little more than half the cost of Central Asian gas, should they compete directly. 
Figure 2: Estimates of costs of gas delivered to Moscow, 2020

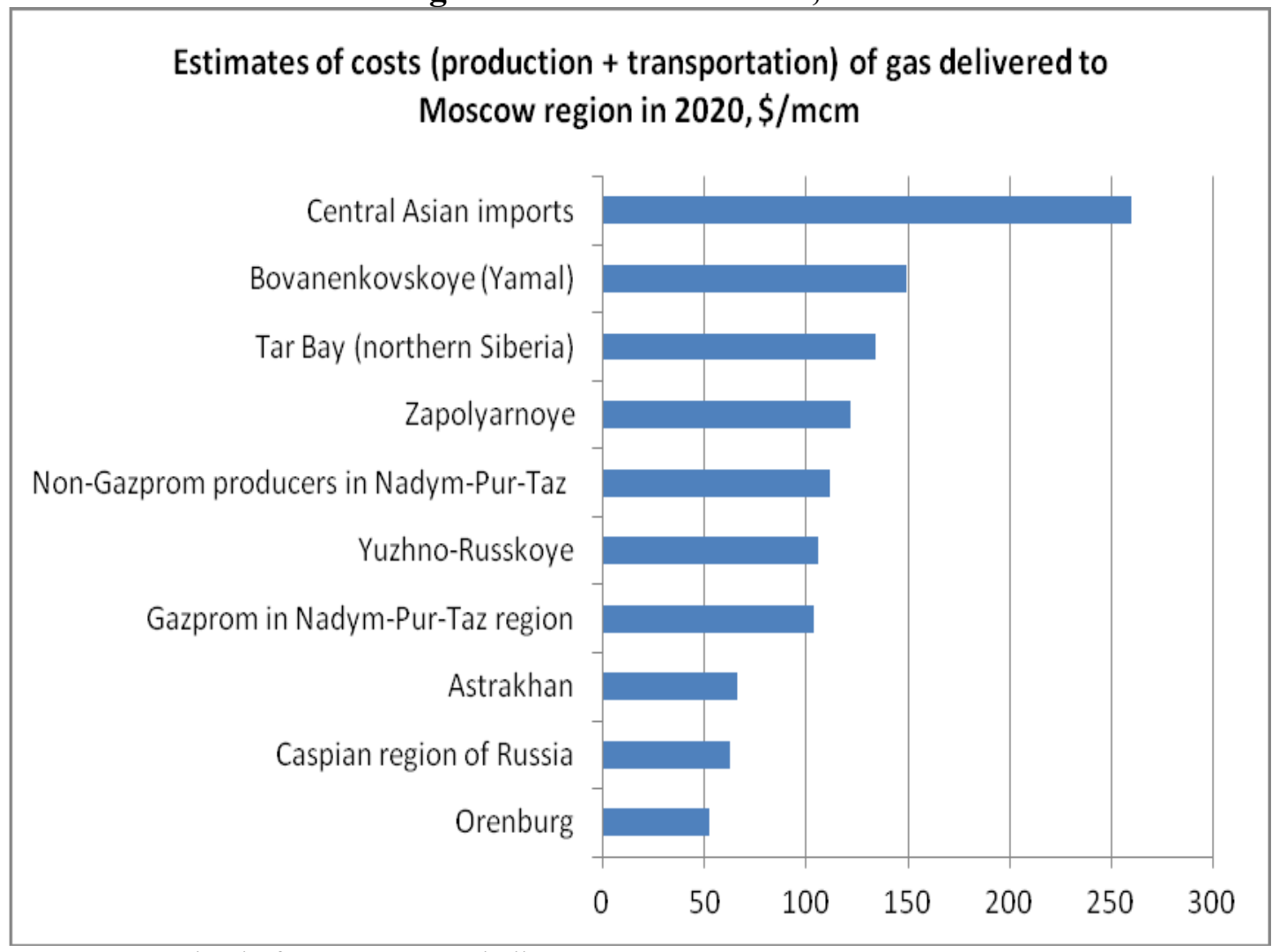

Source: Moscow School of Management, Skolkovo Energy Centre

It is not possible to make certain forecasts about the relative price levels in the Chinese and FSU markets for Central Asian gas in the medium and long term. But it can be said:

(i) that in China, prices will be determined primarily by the direction of government policy and gas market reform;

(ii) that the prices of westward exports will depend on a wider variety of factors, i.e. (a) changes in the European market, (b) the way that Russia and Gazprom adapt their gas export strategy, and the extent to which they continue to pass through European netback prices to Central Asia, (c) the success or otherwise of Ukraine's efforts to reduce its exposure to expensive gas imported from or through Russia, and (d) on the speed and direction of development of the Russian market.

\section{Infrastructure issues: west to east, or east to west?}

Over the medium and long term, Central Asian producers will have a greater degree of choice about whether to export their gas westwards or eastwards. At present they remain constrained by infrastructure. In Turkmenistan, the eastward infrastructure is most easily supplied by new resources in the east of the country (Bagtyiarlyk and South Yolotan), while the westward infrastructure can be supplied most easily from Dauletabad. In Uzbekistan, both westward and eastward routes can be supplied, with modest upgrades, from the main production area, Bukhara-Khiva. In Kazakhstan, the main production areas in the west are tied to the traditional westward route, and new infrastructure, starting with the Beineu-Shimkent pipeline, will be required both to supply domestic consumers in the south east and also to supply the eastward route. 
Prior to the economic crisis of 2008-09 and the reduction of Russian purchases, it was assumed that additional infrastructure would be required for westward exports. Turkmenistan and Kazakhstan had signed memoranda with Russia on the reconstruction of the Caspian Littoral pipeline (also called, confusingly, pre-Caspian from the Russian prikaspiskii). This Soviet-era pipeline carried gas from Turkmenistan's western fields to Russia via Kazakhstan, joining the main Central Asia-Centre pipeline at Beineu, but by 2007 had been reduced to half of its $10 \mathrm{bcm} /$ year capacity. ${ }^{184}$

In mid 2010, Turkmenistan announced that it would build an East-West pipeline linking its eastern fields to the Caspian Littoral line, at an estimated cost of $\$ 2$ billion. Construction of the $720 \mathrm{~km}, 1420 \mathrm{~mm}$ line was begun in 2011 by Turkmenneftegazstroi, the general contractor; it was reported that with three compressor stations (at Sergar, Gumdag and Belek) it would have up to $30 \mathrm{bcm} /$ year capacity, and that 7-800 metres of pipes were being laid per day. ${ }^{185}$

In the light of the reduction of Russian purchases, and the absence of any indication that they will be increased again, the question arises: whom will the east-west pipeline supply? Demand is substantial, and expanding, for eastward exports - while the destination of Turkmen offshore gas developed by Petronas remains unclear and there is a danger of Turkmen offshore resources remaining stranded. It is reasonable, therefore, to speculate that the east-west line could in the future be operated in the opposite direction, to supply Turkmen offshore gas for eastward export - i.e. working in parallel with Kazakhstan's BeineuShymkent line, rather than in the opposite direction. In any case, the existence of both such east-west links will increase flexibility and provide new physical links between the markets in Central Asia-Russia-Ukraine on one side and in China on the other.

\subsection{Exports to Iran}

Turkmenistan has in recent years exported $6-8 \mathrm{bcm} /$ year of gas, and possibly more, to Iran. The signing in 1995 of a 25 -year contract to supply $8 \mathrm{bcm} /$ year of gas, with $35 \%$ of this volume as repayment for Iran's contribution to pipeline construction, marked the first success of Turkmenistan's policy of diversifying exports away from Russia and Ukraine. Exports started in 1997, via the $200 \mathrm{~km}, 40$-inch Korpedzhe-Kurt-Kui pipeline that runs southwards from Turkmenistan's western gas fields. A second $35 \mathrm{~km}$, 48-inch pipeline, running westwards from Turkmenistan's largest producing field, Dauletabad, over the border to Sarakhs and the nearby Khangiran (Hashimi-Nejad) refinery in the north-east of Iran, was commissioned in January 2010. It was extended to Sangbast, near Mashhad, in November 2010. The Turkmen and Iranian governments then stated that Turkmen exports to Iran could rise to $20 \mathrm{bcm} /$ year. $^{186}$

Notwithstanding the completion of this important new export route, disputes continued between the two sides, mainly over the prices to be paid. Turkmenistan reportedly ceased supplies in 2008 and 2009, when Iran refused to agree to prices linked to the high, oil-linked prices being paid in Europe. Reports of a similar dispute over price, and cuts in deliveries,

\footnotetext{
${ }^{184}$ Stern (2012), p. 70; Gazprom press release, “Ob itogakh vizita delegatsii”, 9 April 2009

185 “'Goluboe kol'tso - na karte Turkmenistana”, Neft', Gaz i mineral'nyie resursy Turkmenistana no. 3 2010, pp. 68-71; Turkmenistan.ru, 20 November 2011; "Magistral'nyi gazoprovok Vostok-Zapad stroitsia”, Turkmenistan Zolotoi Vek, 10 April 2012; Bernstein Research, The Caspian: Cradle of Oil Production, p. 71

186 "New Turkmenistan-Iran gas pipeline launched", turkmenistan.ru, 7 January 2010; State information agency of Turkmenistan, "2010 god v letopisi epokhi novogo vozrozhdeniia", 13 January 2011, http://tdh.gov.tm/?id=2426
} 
recurred in November 2012: Iranian oil minister Rostam Qasemi was quoted by Reuters as saying that supplies had been halted due to unresolved price negotiations, a claim denied by Turkmen officials. ${ }^{187}$

Iran's gas reserves are the second largest in the world after Russia's, but demand for Turkmen imports has been driven by rising consumption in heavily-populated northern areas that are not well-connected to Iran's main producing regions in the south and offshore in the Persian Gulf. Iran has a long-term domestic pipeline construction project, the Iranian Gas Trunkline (IGAT) series, which is aimed at bringing its own gas to major consuming regions. Gas is already brought to northern cities including Tehran, the capital, via the IGAT-1 and IGAT-2 lines from the southern part of the country, and via the IGAT-3 line from the South Pars field in the Persian Gulf. Two further pipelines are under construction which, once completed, could bring gas to the northern and north-eastern regions that currently rely on Turkmen gas. These are:

- The 1,050 km, 56-inch IGAT-8 line that Iranian officials said was about $60 \%$ complete in March 2011. A section that runs from Assaluyeh to the Parsian gas processing plant in Fars province, and from there to Isfahan and Qom provinces, was completed in 2009. It is planned to continue, to meet the North and North-East pipeline, in 2014.

- The 1,059 km, 42- and 48-inch North and North-East pipeline, which was more than $70 \%$ complete in March 2011. This consists of two phases, the first running $524 \mathrm{~km}$ from Parchin to Miami and Dasht; and the second running $380 \mathrm{~km}$ from Miami to Sangbast.

Another line, IGAT-11, will also facilitate south-north flows of Iranian gas. ${ }^{188}$

These projects may take time to complete, given the economic problems faced by Iran as the result of trade sanctions and other factors. But once they are finished, the prospect will be raised of price competition between Turkmen gas and Iran's own production. Thus while in the immediate future Turkmen exports to Iran are likely to continue at around the same level, in the long term they could fall or even cease altogether.

Azerbaijan also exports small volumes of gas to Iran, mostly as swaps for small volumes delivered by Iran to the Nakhchivan exclave of Azerbaijan, which is physically divided from the rest of Azeri territory by Armenia. The deliveries to Nakhchivan began in 2004, when a pipeline into Nakhchivan was completed and a 25-year swap contract signed. Roughly 0.5 $\mathrm{bcm} /$ year is exported to swap, and $0.1 \mathrm{bcm} /$ year for Iran, in lieu of transit fees. In 2010 Azerbaijan and Iran reportedly concluded a broader inter-governmental memorandum of cooperation, covering both natural gas trade and electricity swaps in border areas; it apparently envisaged the export of additional volumes via the Kazi-Magomed-Astara pipeline for consumption in northern Iran, but it does not appear that any substantial deliveries have been made. ${ }^{189}$ In 2012, Azeri officials stated that exports are steady at $0.6 \mathrm{bcm} /$ year, comprising $0.5 \mathrm{bcm}$ for Nakhchivan and $0.1 \mathrm{bcm}$ of fuel gas.

\footnotetext{
${ }^{187}$ Adibi and Fesharaki (2011), p. 300; "Iran says Turkmen gas supplies cut in row over terms”, Reuters, 14 November 2012.

${ }^{188}$ With thanks to Elham Hassanzadeh. See also Hedayat Omidvar (National Iranian Gas Company), Iranian Gas Prospect (slide presentation, 2008); US Energy Information Administration, Iran: Country Analysis Brief.

${ }^{189}$ Adibi and Fesharaki (2011), pp. 289-290; World Gas Intelligence, 3 February 2010; Socar Annual Report 2010, p. 3; US EIA web site, “Azerbaijan: natural gas” page; industry information.
} 


\subsection{Exports from Azerbaijan to Georgia, Russia, Turkey and beyond}

Azerbaijan has in recent years turned from being a gas importer to being a gas exporter, as a result of the build-up of associated gas production at the ACG field, and the start-up of the Shah Deniz project. In 2006-07, Azerbaijan started exporting gas to Turkey (now about 6.3 $\mathrm{bcm} /$ year) and Georgia (about $1.5 \mathrm{bcm} /$ year); in 2010 it began exporting small volumes to Russia (1.5 bcm in 2011). Azerbaijan also exports a small amount of gas to northern Iran (0.6 $\mathrm{bcm} /$ year) (see section 5.4 above). Azerbaijan's gas export trade could expand substantially from 2017, when stage II of the Shah Deniz project is expected to be commissioned. Another $6 \mathrm{bcm} /$ year will be available for Turkey, and $10 \mathrm{bcm} /$ year for European buyers. This section covers the export trade, the transport and marketing options for Shah Deniz II exports, and the implications of Azeri government policy directed at making available additional export volumes after Shah Deniz II.

\section{Azerbaijan's current exports}

There are three sources of gas for westward export: (1) about 4-5 bcm/year of associated gas from the ACG field, delivered to Socar free of charge under the field PSA at the Sangachal terminal; (2) part of Socar's own production; and (3) about 6-7 bcm/year from the Shah Deniz field, brought to the Sangachal terminal and sold by the consortium to the Azeri Gas Supply Company, a trading company operated by Statoil on behalf of the consortium. Most of this is exported and sold by AGSC in Turkey; a fixed amount of less than $1 \mathrm{bcm} /$ year is delivered to Georgia at discounted prices as part of a barter arrangement covering transit via the South Caucasus Pipeline; and what remains is sold to Socar under a "swing contract", to add to its gas balance.

Georgia. In recent years, Azerbaijan has supplied more than $90 \%$ of Georgia's imports of 1.5-2 bcm/year. (For 2012, for example, the government set a gas balance of $1.48 \mathrm{bcm}$ for 2012, of which $1.26 \mathrm{bcm}$ will be imported from Azerbaijan, $0.2 \mathrm{bcm}$ imported from Russia and a small amount produced domestically.) Most Azeri exports to Georgia are sold under the barter arrangement mentioned above: Georgia heavily discounts transit tariffs for Azeri oil, and takes transit tariffs for gas through the South Caucasus pipeline in the form of (i) the right to buy $5 \%$ of the gas transported at $\$ 50 / \mathrm{mcm}$ and (ii) up to $0.5 \mathrm{bcm}$ discounted to $\$ 55 / \mathrm{mcm}$ (2006 prices that escalate under a formula). Parallel to these transit-related sales, Socar exports gas at higher, bilaterally-negotiated prices that are somewhat reflective of European netback levels. When these sales started in 2006, Socar priced its gas at $\$ 120 / \mathrm{mcm}$, compared to the $\$ 230 / \mathrm{mcm}$ charged by Gazprom, which until then had a near-monopoly on gas imports to Georgia. Import prices moved to $\$ 187 / \mathrm{mcm}$ in 2009 and $\$ 161 / \mathrm{mcm}$ in $2010 .{ }^{190}$ Azeri gas became available at a time when Georgian-Russian relations were deteriorating sharply; imports from Azerbaijan have now entirely replaced those from Russia. Georgia has also opened a substantial part of its domestic gas market to a Socar subsidiary.

Turkey. Azeri exports to Turkey started in 2007, under a contract providing for $6.3 \mathrm{bcm} / \mathrm{year}$ between Socar and Botas, the Turkish gas company. Prices were set bilaterally, using oillinked formulae, and - as in the case of many of Russia's bilateral arrangements - revised upwards as oil prices rose. The base price used from 2007 was widely reported to be $\$ 120 / \mathrm{mcm}$. In June 2010 a lengthy intergovernmental negotiation concluded with an agreement to raise the base price, and for Turkey to pay retroactively at the new, higher price

\footnotetext{
${ }^{190}$ Tokmazishvili and Bowden (2009). "Georgia to get over 1.2bn cubic meters", News.Az, 2 February 2012. On Socar's non-transit-related sales, AzStat, Foreign Trade of Azerbaijan 2011 (Baku, 2011), pp. 214 and 258.
} 
levels for gas purchased in 2008-09. This agreement also set out the volumes of gas that Turkey would, from 2017, purchase from the Shah Deniz II project and terms on which Shah Deniz gas would be transported through Turkey (see below). Import prices of Azeri gas in Turkey were reported by the Turkish energy ministry in 2011 at $\$ 220 / \mathrm{mcm}$ and $\$ 282 / \mathrm{mcm}$, and in 2012 at $\$ 330 / \mathrm{mcm}$, prices in all cases lower than those of Russian and Iranian imports to Turkey.",191

Greece. From 2007, Botas resold 0.5-0.7 bcm of Azeri gas to Greece. In April 2011, it was agreed to reassign the supply contract between Depa of Greece and Botas to Socar, making Socar the direct supplier of the gas. ${ }^{192}$

Russia. Gas exported to Russia from Azerbaijan is mostly produced onshore, in the northern part of the country, and delivered via the $240 \mathrm{~km}$ Gazi-Magomed-Mozdok pipeline that formerly brought Russian gas to Azerbaijan. The compressor station at Siyazan was refurbished in 2010 to handle the reversal of flows. In October 2009, Gazprom agreed with Socar to buy $0.5 \mathrm{bcm} /$ year in 2010-2015; at a further meeting between the two companies in January 2010, additional volumes of $1 \mathrm{bcm}$ in 2010 and $2 \mathrm{bcm}$ in 2011 were agreed. In the event, volumes were $0.8 \mathrm{bcm}$ in 2010, $1.5 \mathrm{bcm}$ in 2011 and $3 \mathrm{bcm}$ (estimated) in 2010; while prices were $\$ 244 / \mathrm{mcm}$ in 2010 and $\$ 288 / \mathrm{mcm}$ in 2011 . $^{193}$

Iran. See above, section 5.4.

\section{Shah Deniz II}

If the Shah Deniz II project goes ahead as currently planned, a further $16 \mathrm{bcm} /$ year of extra will become available for westward export from 2017-18. This will necessitate the construction of new transport infrastructure. Throughout the 2000s, political hopes were raised in Europe and the USA that these Shah Deniz volumes could become the focus of a large-scale transport project, initiated and financed by consumer countries, that would also bring supplies from Turkmenistan, and perhaps elsewhere, to Europe, and create a new "southern corridor" of supplies. The failure of such projects yet to materialise is discussed below in section 5.6. In their place, over the last two years, plans have been generated for smaller projects, tailored to the transport of Shah Deniz II volumes only, at least to begin with. The government of Azerbaijan has taken the initiative in these projects, and sought greater involvement for Socar in transport, at least as far as the western border of Turkey.

At the time of writing it seems likely, although not certain, that the transport and marketing arrangements for Shah Deniz II gas will be finalised in 2013, and will comprise: (i) expansion of the South Caucasus Pipeline from its current capacity of $7 \mathrm{bcm} /$ year to $23 \mathrm{bcm} /$ year, to bring gas to the eastern border of Turkey; (ii) construction by Socar and Botas of the TransAnatolian pipeline (TANAP) to take the gas across Turkey, probably with the added participation of the other members of the Shah Deniz consortium (BP, Statoil and Total); and (iii) the transportation of the gas from Turkey's western border either to central Europe via the Nabucco West pipeline, a scaled-down version of the larger Nabucco project originally

\footnotetext{
191 “Turkey, Azerbaijan pen three strategic deals”, Today's Zaman, 8 June 2010; "More Shah Deniz surprises in store?", World Gas Intelligence, 2 November 2011; "During 2011 Shah Deniz partners made only \$1,269 billion”, Contact.az, 29 March 2012; Ahmed Mehdi, "Turkish gas price rise not linked to Azeri imports", Interfax Natural Gas Daily, 10 April 2012.

192 “Azerbaijan’s Socar and Greece’s Depa sign MoU”, ICIS Heren, 5 April 2011.

${ }^{193}$ Socar web site, "Gas export department" page; Socar Annual Report 2010, p. 3; AzStat, Foreign Trade of Azerbaijan 2011 (Baku, 2011), p. 258
} 
envisaged for transporting gas directly from the Caspian to Europe, or to Italy via the Trans Adriatic Pipeline (TAP). It is expected that, of the $16 \mathrm{bcm} /$ year of new supplies, the Shah Deniz consortium will sell $6 \mathrm{bcm} /$ year in Turkey and the remainder in European destinations. There are still hurdles to be overcome, i.e. (i) Azerbaijan and the Shah Deniz consortium partners need to reach agreement on transportation and marketing issues, (ii) contracts need to be signed for gas sales in Europe in difficult market conditions.

The evolution of the new plans has been notable for the way that both Azerbaijan and Turkey have sought to take a greater share of the control of transport and marketing arrangements. In Azerbaijan's case, this involvement is seen as a first step in raising Azerbaijan's economic and strategic influence, with further expansion of gas output from fields other than Shah Deniz being linked to further such steps.

A turning point in these processes was the signing of intergovernmental agreements between Azerbaijan and Turkey in June 2010, which not only altered the price formulae for existing gas exports in Azerbaijan's favour, but also mapped out arrangements (i) for the sale of Shah Deniz II volumes in Turkey (with offtake levels set at $2 \mathrm{bcm}$ in 2017, $4 \mathrm{bcm}$ in 2018 and 6 bcm/year from 2019) and (ii) for the transit of the remaining volumes through Turkey. ${ }^{194}$ The background to these agreements was the economic recession in Europe, and the resulting steep fall in gas demand, which placed question marks against previous assumptions about the level of European demand and prices in the late 2010s when Shah Deniz II came on stream. This unpredictability contrasted sharply with the continued expansion of the Turkish gas market.

In 2011, the Shah Deniz II consortium asked the consortia working on the pipeline projects to submit bids to it, stating the terms on which they would make capacity available. By the deadline of 1 October, four proposals were on the table - two (TAP and the Italy-Turkey Greece Interconnector) that envisaged transporting the gas to southern Europe, and two (Nabucco and BP's South East European pipeline (SEEP)) that envisaged taking it to central Europe. But the decision-making process took a new turn within weeks, when the Azeri energy minister, Natiq Aliyev, announced in Istanbul that Azerbaijan and Turkey were working on a pipeline project that would bring gas to Turkey's western border, making the eastern section of the proposed Nabucco pipeline superfluous. In December 2011, statements from Socar and Botas, that they were working on a detailed proposal for TANAP, followed; and in February 2012, a statement from the Turkish energy minister that discussions were in progress about how TANAP and the cut-down version of Nabucco, that would start from Turkey's western border, could cooperate. ${ }^{195}$

In June 2012 an intergovernmental agreement on pipeline construction, and a host country agreement for TANAP, were signed by Azeri president Ilham Aliyev and Turkish prime minister Recep Tayyip Erdogan. The proposed capacity of the 2,000km pipeline has been reported as 16-24 bcm/year, with the possibility of subsequent expansion; some Azeri sources have claimed that initial capacity could be as much as $31 \mathrm{bcm} /$ year. Although details of the TANAP consortium are not public, it has been widely reported that it is owned $80 \%$ by Socar, and that the remaining $20 \%$ is split between Botas and TPAO of Turkey. In November

\footnotetext{
194 “Turkey, Azerbaijan pen three strategic deals", Today's Zaman, 8 June 2010; "More Shah Deniz surprises in store?", World Gas Intelligence, 2 November 2011; Statoil web site, "Shah Deniz" page.

195 "Prospects Appear to Dim for EU-backed Gas Pipeline, Wall Street Journal, 19 Nov 2011; Gulmira Rzayeva and Theodoros Tsakiris, Strategic Imperative: Azerbaijani Gas Strategy and the EU's Southern Corridor (Baku, SAM Center for Strategic Studies, 2012), pp. 16-18; "Nabucco pipelines merger to be discussed", Reuters, 28 Feb 2012; "EU Loses Clout Over Caspian Gas", Wall Street Journal 22 February 2012
} 
2012 it was reported that Socar had agreed to bring the other Shah Deniz consortium members into the TANAP consortium, by selling $12 \%$ to BP, $12 \%$ to Statoil and $5 \%$ to Total. ${ }^{196}$

In the light of the TANAP initiative, the Shah Deniz consortium narrowed down the field of possible pipelines to Europe to two. First it accepted an amended bid from the Nabucco consortium, envisaging a pipeline from the Turkish-Bulgarian border to Baumgarten, named Nabucco West. Then in February 2012 it announced that TAP would be favoured over the Interconnector Turkey-Greece-Italy (ITGI) project as a candidate to carry gas to southern Europe, and in June 2012 announced that Nabucco West would be favoured over SEEP as a candidate to carry gas to central Europe. Gas sales agreements will be signed, and the final choice made between these two options, prior to the Final Investment Decision on Shah Deniz II scheduled for June 2013. After the field was narrowed in this way, consortium members BP and Statoil agreed with the TAP consortium on an option of taking a $50 \%$ equity stake, and a memorandum of understanding signed by Italy, Greece and Albania confirming governmental support. ${ }^{197}$

In addition to Azerbaijan's pipeline diplomacy, Socar has begun to market gas directly to European countries prior to Shah Deniz II coming on stream. In addition to the reassignment to Socar of Botas's contract with Depa of Greece, mentioned above, Socar in April 2012 signed an agreement with BEH of Bulgaria providing for the sale of $1 \mathrm{bcm} /$ year of Azeri gas to Bulgaria from 2014, when the necessary infrastructure between Turkey and Bulgaria is due to be in place. ${ }^{198}$

Remaining problems surrounding Shah Deniz II are (i) whether the recovery of European demand will be sufficient, as assumed, for $10 \mathrm{bcm} /$ year of Shah Deniz gas to find buyers from 2017-18, and (ii) the difficulty in setting price levels and in particular price formulas. Shah Deniz is the largest new source of gas to become available for the European market since the dramatic changes in its structure that have undermined the role of oil-linked price structures. Oil linkage is therefore unlikely to be the predominant pricing method used in the Shah Deniz contracts, if indeed it is used at all. ${ }^{199}$

Possible further expansion of exports

Azeri officials have drawn attention to the importance of putting in place infrastructure sufficient to export not only the new volumes from Shah Deniz, but also volumes that may become available from the fields due to be developed after it. In a recent interview Rovnag Abdullayev, CEO of Socar, pointed out that infrastructure that can "service all these fields and be upgraded as the necessity arises" should be put in place. Reportedly, plans are being considered under which (i) TANAP would have $31 \mathrm{bcm} /$ year capacity initially, and would be scalable up to $60 \mathrm{bcm} /$ year; and (ii) that in place of the planned South Caspian pipeline expansion to $23 \mathrm{bcm} /$ year, a more ambitious expansion should be undertaken, with Socar as

\footnotetext{
${ }^{196}$ Andrew Neff, “Turkey, Azerbaijan Sign Inter Governmental Agreement on TANAP pipeline”, 26 June 2012, IHS Global Insight Daily analysis; "Europe's plan to control Azeri gas supply in jeopardy", Reuters, 3 August 2012; Rzayeva and Tsakiris, Strategic Imperative, p. 18; "BP, Total, Statoil to take stakes in TANAP", Platt's European Gas Daily, 8 November 2012

${ }^{197}$ BP press release, "The Nabucco West project has been selected", 28 June 2012; "BP, Socar, Total pledge to fund gas pipeline”, Reuters, 9 August 2012

${ }^{198}$ Reuters, "Bulgaria, Azerbaijan sign accord on gas cooperation", 27 April 2012

${ }^{199}$ The issues in Europe are dealt with in detail in Stern and Rogers (2012), pp. 145-177.
} 
the operator. ${ }^{200}$ The implication of TANAP having a capacity of $31 \mathrm{bcm} /$ year is that, in addition to the Shah Deniz II gas, another $15 \mathrm{bcm} /$ year will be available for export. My estimates, drawn up on the basis of Socar's own projections of output for 2025 and shown in Table 24, suggest that even with fairly optimistic assumptions, the amount of additional gas available will only be half of that.

Table 24: Azerbaijan: estimates of gas production and sales in 2005

\begin{tabular}{|c|c|c|c|}
\hline \multicolumn{2}{|c|}{ Rounded to nearest bcm } & 2011 & 2025 \\
\hline \multicolumn{2}{|c|}{ Production (total) } & 26 & $50-55$ \\
\hline Production: & Current assets & 26 & 25 \\
\hline & Shah Deniz II & 0 & 16 \\
\hline & New projects & 0 & $9-14$ \\
\hline \multicolumn{2}{|c|}{ Reinjected, flared, field use } & 9 & 10 \\
\hline \multicolumn{2}{|c|}{ Sales gas } & 17 & $40-45$ \\
\hline \multicolumn{2}{|l|}{ Total } & 17 & $40-45$ \\
\hline Sales gas: & Domestic sales & 7 & 10 \\
\hline & Export - current destinations & 10 & 11 \\
\hline & Shah Deniz II - Turkey & 0 & 6 \\
\hline & Shah Deniz II - Europe & 0 & 10 \\
\hline & $\begin{array}{l}\text { Incremental volumes for export } \\
\text { westwards }\end{array}$ & 0 & $3-8$ \\
\hline
\end{tabular}

Source: author's estimates

As argued in section 3.4 above, the projection of $50-55 \mathrm{bcm} /$ year of total production (prior to reinjection, flaring and own use) is reasonable, assuming succesful exploration outcomes. It is assumed that at least two of Azerbaijan's post-Shah Deniz II projects can be developed by 2025, and Socar's estimate implies that their aggregate output would be $9-14 \mathrm{bcm} /$ year (all of it sales gas, since the projects are in natural gas and not associated gas fields). However, in Table 24 those numbers are eroded by further (very benign) assumptions: that the amount of reinjected, flared and own-use gas goes up from $9 \mathrm{bcm} /$ year to $10 \mathrm{bcm} /$ year (given that, more than a decade from now, it is likely that extra reinjection will be required to maintain pressure in the ACG field); that the output from current assets falls by $1 \mathrm{bcm} / \mathrm{year}$ (and it could easily be more); that domestic gas consumption rises by $3 \mathrm{bcm} /$ year (which is in line with assumptions made by those working in the industry); and that the requirements of Azerbaijan's current export customers (Turkey, Russia, Georgia and Iran) increase by 1 bcm/year (and it could easily be more - Russia's purchases are due to rise by that amount under a framework agreement already signed).

The conclusion is that there are no more likely to be sufficient volumes to justify a TANAP start-up capacity of $31 \mathrm{bcm} /$ year than there were for a $31 \mathrm{bcm} /$ year Nabucco pipeline. There is no reason to believe that incremental Azeri gas production could exceed Socar's expectations by such a huge margin by 2016, the projected start-up date, or even 2020 . Beyond the end of the decade, far-reaching economic or political changes could make available other sources of supply, e.g. (in the case of a change in the relationship between Iran and the western powers), Iranian gas or Turkmen gas transported via Iran.

200 “Scalability as Drawn”, Azerbaijan 2012: The Business Year, pp. 92-93; Rzayeva and Tsakiris, Strategic Imperative, pp. 15 and 17. This paper cites the energy minister on the capacity of TANAP. 


\subsection{Other possible export routes}

The selection by the Shah Deniz consortium of Nabucco West and TAP as the two favoured bidders to provide transportation - and the implication that gas would reach Turkey's western border via TANAP or a similar, separate project - brought to an end a decade-long phase of European planning for a large-scale integrated Caspian-to-Europe gas transport project. The Nabucco project in its original form, i.e. a single pipeline from Erzurum in eastern Turkey to European locations, has been superseded; European political efforts to get commitments from Turkmenistan to supply gas volumes for such a project, and from Turkmenistan and Azerbaijan to construct a Trans-Caspian pipeline to transport them, have not yet borne fruit. By contrast, the infrastructure needed to take Turkmen gas to China - first mooted in 2006, four years after preparations for Nabucco began - has been planned, agreed upon by governments, built and commissioned, and is now being expanded. This section covers some reasons why the gas supply route from Turkmenistan to Europe remains closed, and the difficulties that surround the route from Turkmenistan to south Asia, which has yet to move from the political sphere to the commercial.

\section{Possible routes from Turkmenistan to Europe}

The geographical attraction of a Trans-Caspian pipeline (TCP) is obvious (see maps 1 and 5): the distance from the westernmost Turkmen offshore gas fields to Baku is relatively short. The perceived political attraction to the European Union and the USA is also well known, i.e. that Turkmenistan's substantial gas resources would become available to European customers, further reducing dependence on Russia for energy supplies. It was therefore logical that European countries would take an interest in this issue in the early 2000s as gas demand rose. Three categories of difficulty arose, though, which have yet to be overcome: first, those arising from Turkmenistan's export policy and attitude to its role as a gasproducing nation; second, the mismatch of political and commercial interests in Europe; and third, legal and political problems surrounding international cooperation between Caspian nations.

1. Turkmenistan's export policy has been consistent throughout the post-Soviet period: (i) in line with its "multi-vector" foreign policy it has made no distinction between potential buyers on political or strategic grounds; but (ii) it is ready to sell gas only on its border, with transport and other risks taken by the buyer from that point onwards. This implies that pipeline construction, too, should be undertaken by the buyer. Turkmenistan has adhered to this principle with regard to a possible Trans-Caspian route: while senior Turkmen officials, from the president downwards, have often made positive statements about its desirability, Turkmenistan has never taken the initiative e.g. by seeking agreement with Azerbaijan to form a pipeline construction consortium.

Turkmenistan's national interest, as interpreted by all its post-Soviet governments, is served by maintaining peaceful relationships with all its neighbours, while ensuring sufficient gas export sales to meet its perceived needs for revenues. Statements about increasing production beyond the level required to assure that income (e.g. to 100-200 bcm/year or even beyond) may express long-term aspirations, but bear no relation to real Turkmen policymaking, as I have argued in section 2 above. From this standpoint, the importance of the agreements with China on gas exports cannot be stressed enough. They assured Turkmenistan of a second major export destination alongside Russia, and of a source of export revenues, more reliable than Russia had been in the post-Soviet period, for several decades to come; they enabled the 
Turkmen government confidently to see through the 2009 dispute with Russia. The question asked so often in Europe in 2009-12 - why is Turkmenistan not giving greater priority to the Trans-Caspian route? - was the wrong one. The question from a Turkmen point of view was: why, in the light of success with China, should any priority at all be attached to the TransCaspian route? The answer was that, while Turkmenistan remained interested in the idea, it was not urgent enough for it to break with its policy of leaving pipeline construction and transit risks to the buyer - a policy that presented no obstacle to China.

2. Mismatch of interests in Europe. The European Commission responded to Turkmenistan's export policy (i) with diplomatic efforts aimed at persuading Turkmenistan and Azerbaijan to overcome legal and political obstacles to a TCP, and (ii) by proposing in 2009 the creation of the Caspian Development Corporation, envisaged as a single commercial vehicle that could aggregate the purchase of Turkmen gas. Finally, in apparent desperation at the lack of progress, the Commission in September 2011 secured an unprecedented decision by the EU's governing Council, mandating it to negotiate a legally-binding treaty with Turkmenistan and Azerbaijan providing for pipeline construction. ${ }^{201}$ This was the first time such powers had been given to the Commission with respect to an infrastructure project.

The sponsors of the Nabucco project could hardly have asked for a stronger political signal to be sent to the Shah Deniz consortium, which in October 2011 received bids from pipeline consortia for transporting its gas to European destinations. But the Shah Deniz consortium operated strictly on commercial principles, and once Azerbaijan and Turkey had decided to move forward with TANAP, accepted the revised Nabucco bid for a pipeline starting from the western border of Turkey. All this amounted to recognition in practice that, even with the exceptional efforts of the EU Council, progress towards bringing Turkmen gas across the Caspian had fallen short of what was needed for commitments to be made to build pipelines.

The difficulty of securing an agreement with Azerbaijan and Turkmenistan on a TCP was not the only obstacle in the Commission's path. It was assumed that a TCP could only be financed on the basis of $30 \mathrm{bcm} /$ year worth of sales, and the Commission also faced, after the 2008-09 economic crisis, reluctance from European energy companies to commit to the longterm gas purchase contracts necessary for this. IHS Cera, who were retained to create an institutional design and commercial framework for the Caspian Development Corporation, surveyed major energy companies as potential participants, and found that while they were "ready and willing to begin talking about specific volume commitments", a number of them were "concerned about the risk of taking on potentially onerous new take-or-pay contracts in an environment of short term, and possibly long term, demand uncertainty". IHS Cera also reported companies' "surprise" that the European Commission was championing a coordinated purchase model, having for the previous 20 years been "pushed in the other direction [...] to allow for more direct competition", and in some cases faced regulatory risks and even substantial fines, for practices that they perceived had followed from "coordinated purchase of gas and shipping capacity". ${ }^{202}$ One of IHS Cera's key proposals was that the single-buyer model would require either a guidance letter from the EC's competition directorate, or preferably a formal exception to competition rules by the Commission, at an early stage. ${ }^{203}$

\footnotetext{
${ }^{201}$ See European Commission, On security of energy supply and international cooperation: "The EU Energy

Policy: Engaging with Partners Beyond Our Borders" (COM (2011) 539), 7 September 2011

202 IHS Cera, Caspian Development Corporation: Final Implementation Report (December 2010), p. 12

${ }^{203}$ IHS Cera, op. cit., p. 5
} 
An important conclusion about the failure yet to open up a Turkmen-European route, therefore, is that - given Turkmenistan's consistent policy of seeking to sell gas on its borders - the European Union's political drive to make this possible was not matched by the necessary commitment from European energy companies, due above all to (i) the market uncertainty created by the recession, and (ii) concerns that a single-buyer model, that the Commission perceived as being necessary to negotiate with Turkmenistan, conflicted with EU competition rules. The mismatch between political and commercial interests in Europe, and the tension between the need for a joint approach to Turkmenistan and EU competition principles, contrasts sharply with the Chinese approach. This was spearheaded by CNPC, a state-owned corporation that, on the basis of government decisions, was able to commit to the huge investment costs of the Turkmenistan-China pipeline, and was able to call on the support of Chinese state-owned banks that financed a large part of the Turkmen upstream investments required to supply the project.

3. Caspian political issues. The legal and diplomatic problems for the TCP are well-known and have been described in detail elsewhere. ${ }^{204}$ The first is that since the dissolution of the Soviet Union, no agreement has been reached between the Caspian littoral states (Russia, Kazakhstan, Turkmenistan, Azerbaijan and Iran) on the territorial delimitation of the Caspian Sea. Some legal opinion asserts that this issue need not obstruct a TCP supported by Turkmenistan and Azerbaijan. And indeed in November 2010 president Berdymukhammedov stated at a meeting of the littoral states that any transport project supported by any two states should not require the permission of others. ${ }^{205}$ Senior Turkmen officials clarified, though, that only three of the five states (presumably Azerbaijan, Turkmenistan and Kazakhstan) had endorsed this position. This underlined the political reality: that it is in the interest of neither Russia nor Iran to hasten the development of a Turkmen-Europe gas corridor, and there is no obvious motive for Azerbaijan and/or Turkmenistan to push a project of which their larger neighbours strongly disapprove (and from which Azerbaijan potentially has much to lose commercially).

The second obstruction to progress is the border dispute between Azerbaijan and Turkmenistan themselves: both claim sovereignty over the Serdar-Kyapaz oil field in the mid Caspian. Although they have maintained reasonable relations in spite of this, the dispute flares up periodically - most recently in June 2012, when Azeri border guards ordered a Turkmen vessel conducting seismic work out of the area, on the grounds that its presence violated a 2008 agreement that neither side would work on the field until the maritime borders were delimited. Turkmenistan subsequently announced that it would take this dispute to an international court of arbitration. ${ }^{206}$

None of these accumulated problems mean that a Turkmen-European gas supply route cannot be opened. But they do suggest that greater motivation both from Turkmenistan as a producer nation, and from European energy companies as buyers, will be required in order to overcome the considerable political obstacles. A reminder of how difficult the process will be without such motivation came in August 2012 when the EU Energy Commissioner Gunther Oettinger, having recruited Turkey to the diplomatic efforts behind the pipeline, visited Ashgabat to discuss this with president Berdymukhammedov, only to be refused a meeting. ${ }^{207}$

\footnotetext{
${ }^{204}$ See e.g. Pirani (ed.) (2009) especially pp. 282-284 and 298-299

${ }^{205}$ Reuters, "Total CEO meets Turkmen president”, 24 November 2010

${ }^{206}$ Interfax, “Azerbaijan warns Turkmenistan over Kyapaz oil field”, 18 June 2012; UPI, “Turkmenistan takes action over oil dispute", 2 July $2012<$ http://www.upi.com/Business_News/Energy-

Resources/2012/07/02/Turkmenistan-takes-action-over-oil-dispute/UPI-56191341233607/>

207 “Turkmenistan Snubs EU Over Trans Caspian Pipeline”, NefteCompass, 20 September 2012
} 
Apart from a breakthrough on a TCP driven by economic imperatives, any rapprochement between Europe and Iran - however politically unlikely it is at present - would open the possibility of gas transport via existing infrastructure linking western Turkmenistan to northern Iran and thence to Turkey. This could be upgraded with a relatively modest level of investment.

\section{Possible routes from Turkmenistan to Pakistan and India}

The possibility of a Turkmenistan-Afghanistan-Pakistan-India (TAPI) gas pipeline has been mooted in diplomatic circles for many years. The most recent round of discussions on the subject received an impetus in December 2010, when the governments of Turkmenistan, Afghanistan, Pakistan and India signed inter-governmental memoranda, a gas pipeline framework agreement and heads of agreement on the terms of gas sales in Ashgabat. One obvious obstacle to the project is the security situation in Afghanistan, and to some extent Pakistan - although the USA energetically supports TAPI as a "peace pipeline", i.e. sees potential benefits to the stability of Afghanistan. In 2011, US deputy assistant secretary of state Susan Elliott addressed an industry event in Ashgabat and, while pointedly failing to mention the "southern corridor" between the Caspian and Europe, lauded the future TAPI as a means to "a stable and secure Afghanistan", that would "provide revenue and jobs for Afghanistan at a critical stage of its economic development", while also supplying clean fuel to Pakistan and India. ${ }^{208}$

During 2011, diplomatic contacts continued, while oil and gas executives in the region considered reports of the price at which Turkmen gas might be delivered in Pakistan or India. Although no firm announcements were made, reports suggested that Pakistan was seeking 14 $\mathrm{bcm} /$ year of gas at $70 \%$ of Brent oil prices per unit of energy at Multan (which at late 2011 oil prices of around $\$ 100 /$ barrel implied a gas price around $\$ 11 / \mathrm{mmbtu}$ ). Other reports indicated a landing price in India, including transport, of $\$ 13 / \mathrm{mmbtu}$ with oil prices at around $\$ 100 /$ barrel, i.e. roughly three times what ONGC, the state-owned Indian oil and gas corporation, pays for gas produced domestically. ${ }^{209}$

In May 2012, GAIL (India) and Inter State Gas System of Pakistan signed gas sales and purchase agreements with Turkmenistan that provide for the delivery of an aggregate 32.8 $\mathrm{bcm} /$ year via the pipeline. ${ }^{210}$ It was expected that an Afghan energy company would sign a similar deal shortly, although one has not been forthcoming in the succeeding months. The Asian Development Bank, which has acted as the TAPI Secretariat since 2002, stated that the next step would be for the four TAPI nations to attract commercial partners to build, finance and operate the pipeline.

There are some similarities between the problems facing the "southern corridor" projects and those facing TAPI. In both cases, negotiations have been driven forward at government level, on the basis of strategic aims, but these political drivers have not been matched by economic imperatives strong enough to convince energy companies to invest the large sums required for complicated infrastructure projects. In TAPI's case, it is significant that a few weeks after the gas sales and purchase agreements were signed - a breakthrough never achieved by

\footnotetext{
${ }^{208}$ US State Department, "Deputy Assistant Secretary for Central Asia Susan Elliott's Remarks for Turkmenistan International Oil and Gas Conference”, 17 November 2010, Ashgabat

${ }^{209}$ British Embassy in Ashgabat, Updates on the Energy Sector, January 2012; BMI, Turkmenistan Oil \& Gas Report Q1 2012, p. 20

${ }^{210}$ ADB press release, "Historic Agreements Bring Long-Awaited TAPI Pipeline Closer", 23 May 2012
} 
supporters of projects to take Turkmen gas westward - an agreement was signed by the presidents of China and Afghanistan supporting a feasibility study, to be conducted by CNPC, on a pipeline taking Turkmen gas via northern Afghanistan and Tajikistan to China. ${ }^{211}$ This not only served as a reminder to Kazakhstan that China could import gas via routes that did not cross its territory, as mentioned above in section 5.2, but also underlined the fact that China would not wish to hasten the construction of TAPI.

${ }^{211}$ Vladimir Socor, "Beijing Proposes Turkmenistan-China Gas Pipeline Through Northern Afghanistan”, Eurasia Daily Monitor, 19 June 2012 


\section{Future outlook and conclusions}

In considering how the Central Asian and Caspian gas sector might develop up to the end of the decade, the economic, political and social factors mentioned in section 2 should be borne in mind. Turkmenistan will surely overtake Uzbekistan again and become the largest producer of gas in the region; it also has the greatest potential for increasing exports. But the extent to which it does so will be determined partly by its size, political structure and foreign policy. Its underground gas resources may be extensive, but its above-ground management and engineering capacities are limited. Foreign companies (excluding the Chinese stateowned companies) may see their provision of these capacities as the obvious solution, but the Turkmen government will probably remain cautious about dealing with them. Its agreements with China provide a framework under which it can develop South Yolotan and other resources. The target set recently by the Chinese and Turkmen presidents, of $65 \mathrm{bcm} /$ year exports, implies a total of up to $110 \mathrm{bcm} /$ year production all together (adding to China-bound exports e.g. up to $10 \mathrm{bcm} /$ year to Iran, $11 \mathrm{bcm} /$ year to and through Russia, $4 \mathrm{bcm} /$ year to Central Asian countries and $20 \mathrm{bcm} /$ year for the domestic market).

The case made here is that, even if all those figures were reduced e.g. by one quarter (i.e. if Turkmenistan were producing $73 \mathrm{bcm} /$ year and exporting $58 \mathrm{bcm} /$ year of it), it would still probably have revenues in excess of spending requirements. (It should be recalled that Turkmenistan began to accumulate its foreign exchange reserve fund in the early 2000s, when it was selling gas to Russia and Ukraine for $\$ 50 / \mathrm{mcm}$, part of which was paid in barter. The state budget has of course increased since then, but not by the same proportion as gas prices have increased.) While Turkmen government policy is to increase gas production and exports to underpin a "golden age" for the country, it should be possible for it to implement this largely on the basis of its exports to China, even if they fall short of the targets mentioned.

For either a European or a south Asian export route to be opened up from Turkmenistan, the government would have to be faced with (i) a group of buyers in those locations prepared to commit in advance to the substantial investments and purchase commitments required to finance the route, and (ii) a set of compelling reasons to tackle all the difficulties (political, managerial, commercial) that would surround the required increase in production. These routes may yet be opened up, but not before the end of this decade.

As for exports to and through Russia, the steady movement towards the operation of market mechanisms in Russia's gas sector suggests that the exports at high, oil-linked prices that the Central Asian countries enjoyed in the mid 2000s are unlikely to be resurrected. Russia's current purchase prices in Central Asia are far above the prices in its domestic market and, should Central Asian gas compete in Russia with Russian gas - rather than being transported to Ukraine and Europe and sold at netback prices - demand for it would fall. This outcome seems likely. In the Russian market, Turkmen gas would have to compete not only with Gazprom production, but with the large volumes of low-cost gas produced by non-Gazprom producers who are increasingly gaining access to transport infrastructure for these volumes. One significant bellweather will be Turkmenistan's East-West pipeline, due for completion in 2015. It was conceived in the mid 2000s as a means of bringing gas from eastern Turkmen fields westwards. Now, with Turkmen offshore gas in danger of being stranded, and the Chinese export route open, it is not beyond the realms of possibility that it could be used in the opposite direction, or at least used to give Turkmenistan greater flexibility in deployment of its eastern and western resources. 
Scepticism has been expressed in the paper about Turkmenistan confronting problems drastic enough for it to try to ramp up production above $100-150 \mathrm{bcm} /$ year, or hurriedly to revise its policies on upstream development (that non-Chinese IOCs will not be given access to reserves) and exports (that it sells gas at the border, leaving transport and marketing risks with purchasers). It is not intended to suggest, however, that Turkmenistan's relationship with China is free of problems. China decided to construct the pipeline from Turkmenistan, and to pay a premium for gas delivered, for strategic reasons. But, towards the end of the decade, or in the 2020s, developments in Chinese and other gas markets could cause a reassessment of these arrangements. Turkmen exports to and through Russian are likely to remain at a reduced level, and those to Iran could be reduced or even stopped. In short, Turkmenistan could become the supplier of last resort to these markets. This would make it more dependent than it wishes to be on Chinese purchases - and vulnerable to demands from China that prices be renegotiated.

Social factors are important in all hydrocarbon-producing countries, however small their populations, as last year's events in north Africa showed. In Turkmenistan, it seems likely that the government, mindful of the importance of meeting social expectations, will continue with the provision of energy either free or at very low cost both to the population and to industry. This should not present any insuperable difficulty. In Uzbekistan, however, things are different: the population is more than five times the size of Turkmenistan's, and the level of domestic gas consumption is worryingly close to total production. The near-crisis conditions in Uzbekistan's domestic energy sector - the worsening supply difficulties at peak times of year, the substitution of imported oil products with gas, the lack of coordination between energy-saving policies and those designed to stimulate small industry with cheap energy - make it impossible to project with any confidence whether gas consumption will go up or down, let alone by how much.

A further enigma in Uzbekistan is that while new fields are certainly being developed to replace those in natural decline, a large proportion of this development is being undertaken, under PSAs or joint ventures, by foreign companies whose business models imply exporting the gas. Those companies have collectively set their sights on $17 \mathrm{bcm} /$ year of incremental exports by the end of this decade, as shown in section 3.2. As for the fields that serve the domestic market, there is no firm information either about the pace of decline of existing production, or about the measures being taken to replace it. It seems likely that, once the exports from fields developed by foreign companies are set aside, Uzbek gas supply will be squeezed. The conclusion here is that, first, Uzbekistan will cede its Central Asian export trade (up to $4 \mathrm{bcm} /$ year) to Turkmenistan; second, it may well be compelled not only to prioritise energy-saving measures, but also to abandon some of its more energy-intensive industrial policies. Beyond that, there are only drastic scenarios: swingeing, compulsory power cuts; renegotiation of terms with foreign producing companies; revision of energy pricing policy; etc.

On the demand side, social factors will also play an important part in Kazakhstan. While the government's target of raising gas consumption to $24 \mathrm{bcm} /$ year (i.e. more than doubling it) may not be reached by the end of the decade, progress will be made in that direction. The government of Kazakhstan, by far the largest hydrocarbons producer in the region, feels a particularly acute need to show the population that it is benefiting from the oil boom. Mangistau, one of Kazakhstan's main oil-producing regions and also one of its poorest, was last year affected by one of the most serious waves of social unrest in Central Asia in postSoviet times. The government's policy, of raising oil exports but basing its domestic energy policy more heavily on associated gas utilisation and gasification, is therefore unlikely to 
change. During the long-running dispute between government and foreign companies over this policy, the companies have often argued that many of the utilisation and gasification measures are not economically rational. But the government will probably continue to see this issue from a political rather than an economic point of view. So while Kazakhstan will raise gas output, mainly as a result of the start-up of the first phase of the Kashagan project, the incremental gas will to the end of the decade be shared between the domestic market and the start-up of small volumes of exports to China.

Apart from the opening of the Chinese export route, the other significant change in the region this decade is likely to be the growth of Azeri exports to Turkey and the start of Azeri exports to European countries. But this will become certain only after the final investment decision on the Shah Deniz II project, due in mid 2013. With Shah Deniz II gas, Azerbaijan could be exporting $13 \mathrm{bcm}$ to Turkey and $10 \mathrm{bcm}$ to European destinations by the end of the decade. Beyond that, on the supply side there are several Caspian projects at the pre-development stage that could be producing some gas by 2020. On the demand side, the proximity of Turkey, where the gas market is expanding much faster than it is in Europe, will be a crucial factor; there could also be some small incremental Azeri exports to Russia and Georgia.

Taking all these factors into account, Table 25 has been drawn up with a view to focusing on possible changes. To the extent that the assumptions in the right-hand column are valid, the columns for 2015 and 2020 give an indication of how gas balances could look in those years. If those assumptions prove to be incorrect, elements in the balances will change. 
Table 25: Gas Balances: projections (Bcm)

\begin{tabular}{|c|c|c|c|c|}
\hline & 2011 & 2015 & 2020 & Assumptions \\
\hline \multicolumn{5}{|l|}{ Turkmenistan } \\
\hline Production (total) & 54.0 & 76.7 & 85.9 & S Yolotan will be developed \\
\hline Reinjected \& flared & 2.0 & 2 & 2 & \\
\hline Production (sales gas) & 52 & 74.7 & 83.9 & \\
\hline Domestic consumption & 17 & 18 & 19 & \\
\hline Export (total) & 35 & 56.7 & 64.9 & \\
\hline Export to/through Russia & 11.2 & 6 & 6 & $\begin{array}{l}\text { Will fall, as market conditions trump } \\
\text { politics }\end{array}$ \\
\hline \multirow{2}{*}{$\begin{array}{l}\text { Export to Iran } \\
\text { Export to Kazakhstan }\end{array}$} & 8 & 10 & 10 & Will rise slightly \\
\hline & 0.3 & 3 & 1.2 & $\begin{array}{l}\text { Turkmenistan will take over Uzbek exports, } \\
\text { which will then be substituted by domestic } \\
\text { gas }\end{array}$ \\
\hline $\begin{array}{l}\text { Export to } \\
\text { Kyrg'n/Tajikistan }\end{array}$ & 0 & 0.7 & 0.7 & Turkmenistan will take over Uzbek exports \\
\hline Export to China & 15.5 & 37 & 47 & $\begin{array}{l}\text { Most, but not all, of volumes envisaged in } \\
\text { agreements }\end{array}$ \\
\hline Total & 52 & 74.7 & 83.9 & \\
\hline \multicolumn{5}{|l|}{ Uzbekistan } \\
\hline Production (total) & 57.7 & 58.5 & 62.5 & \\
\hline Reinjected \& flared & 2.5 & 2.5 & 2.5 & \\
\hline Production (sales gas) & 55.2 & 56 & 60 & PSAs will offset falling output \\
\hline Domestic consumption & 44.3 & 44 & 45 & $\begin{array}{l}\text { Efficiency gains offset by demand stimuli. } \\
\text { Surgil plant built but not Uzbek'n GTL }\end{array}$ \\
\hline & 10.9 & 12 & 15 & \\
\hline \begin{tabular}{l|l} 
Export (total) \\
Export to/through Russia
\end{tabular} & 8.0 & 7 & 5 & $\begin{array}{l}\text { Will fall, as market conditions trump } \\
\text { politics }\end{array}$ \\
\hline Export to Kazakhstan & 2.1 & 0 & 0 & Will cease \\
\hline Export to Kyrg/Taji & 0.8 & 0 & 0 & Will cease \\
\hline \multirow{2}{*}{$\begin{array}{l}\text { Export to China } \\
\text { Total }\end{array}$} & 0 & 5 & 10 & Most Lukoil gas will go to China \\
\hline & 55.2 & 56 & 60 & \\
\hline \multicolumn{5}{|l|}{ Kazakhstan } \\
\hline Production (total) & 39.5 & 47 & 52.5 & Kashagan peaks by 2020 , some extra output \\
\hline Reinjected \& flared & 21 & 25.5 & 27.2 & onshore (Zhanazhol, etc) \\
\hline Production (sales gas) & 18.5 & 21.5 & 25.3 & \\
\hline Import & 4.7 & 5 & 3.2 & \\
\hline Import from Russia & 2 & 2 & 2 & Swaps will continue \\
\hline \begin{tabular}{|l|} 
Import from \\
Turkmenistan \\
\end{tabular} & 0.3 & 3 & 1.2 & $\begin{array}{l}\text { Turkmen imports, then domestic gas, will } \\
\text { replace Uzbek imports }\end{array}$ \\
\hline Import from Uzbekistan & 2.4 & 0 & 0 & Will cease \\
\hline Total & 23.2 & 26.5 & 28.5 & \\
\hline Domestic consumption & 11.2 & 16.5 & 19.5 & $\begin{array}{l}\text { Government targets met, but not in full. } \\
\text { Tengiz petrochemical plant built }\end{array}$ \\
\hline Export (total) & 12 & 10 & 9 & \\
\hline \begin{tabular}{l|l} 
Export to/through Russia \\
\end{tabular} & 11.9 & 7.8 & 5.8 & Will fall due to market; swaps continue \\
\hline $\begin{array}{l}\text { Export to } \\
\text { Kyrg'n/Tajikistan }\end{array}$ & 0.1 & 0.2 & 0.2 & $\begin{array}{l}\text { Kazakhstan will supply northern } \\
\text { Kyrgyzstan }\end{array}$ \\
\hline Export to China & 0 & 2 & 3 & Beineu-Shymkent line will be completed \\
\hline Total & 23.2 & 26.5 & 28.5 & \\
\hline
\end{tabular}




\begin{tabular}{|c|c|c|c|c|}
\hline & 2011 & 2015 & 2020 & Assumptions \\
\hline \multicolumn{5}{|l|}{ Azerbaijan } \\
\hline Production (total) & 25.7 & 29 & 47 & \multirow{2}{*}{$\begin{array}{l}\text { Shah Deniz will start, and one of the other } \\
\text { offshore projects }\end{array}$} \\
\hline Reinjected \& flared & 9.3 & 9.7 & 10 & \\
\hline Production (sales gas) & 16.4 & 19.3 & 37 & \\
\hline Import & 0.5 & 0.5 & 0.5 & \multirow{2}{*}{$\begin{array}{l}\text { No agreement with Armenia, so } \\
\text { Nakhchivan swaps continue }\end{array}$} \\
\hline Import from Iran (swaps) & 0.5 & 0.5 & 0.5 & \\
\hline Total & 16.9 & 19.8 & 37.5 & \\
\hline Domestic consumption & 7.0 & 9 & 9 & \\
\hline Export (total) & 9.9 & 10.8 & 28.5 & \\
\hline Export to/through Russia & 1.5 & 2 & 2.5 & Will rise gradually \\
\hline Export to Iran (swaps etc) & 0.6 & 1 & 1 & Will rise by $0.5 \mathrm{bcm}$ \\
\hline Export to Georgia & 1.5 & 1.5 & 2 & Will rise by $0.5 \mathrm{bcm}$ \\
\hline Export to Turkey & 6.3 & 5.6 & 13 & \multirow{2}{*}{$\begin{array}{l}\text { In } 2015 \text {, Azeri direct sales to Greece } \\
\text { continue. } \\
\text { In } 2020 \text {, Shah Deniz exports, as agreed }\end{array}$} \\
\hline Export to Europe & 0 & 0.7 & 10 & \\
\hline Total & 16.9 & 19.8 & 37.5 & \\
\hline
\end{tabular}

Sources: Table 4 (2011 gas balances); author's estimates

Important points to draw attention to are:

- The volume of exports to China - $47 \mathrm{bcm} /$ year from Turkmenistan, $10 \mathrm{bcm} /$ year from Uzbekistan and $5 \mathrm{bcm} /$ year from Kazakhstan - are set on the assumption that most, but not all, of the volume increase envisaged in Sino-Turkmen agreements will be achieved. This could be because field development will take longer than previously thought, or because of other difficulties that surround any project of the scale of South Yolotan, or because pricing issues in the Chinese market impact on CNPC's volume requirements. An alternative and perfectly plausible assumption is that Turkmen exports to China will exceed $47 \mathrm{bcm} /$ year by this time - but that would imply either further infrastructure expansion (the three lines of the Turkmenistan-China pipeline have a projected capacity of $65 \mathrm{bcm} /$ year plus a possible extra $5 \mathrm{bcm} /$ year on Line B), or that Uzbek and Kazakh exports are lower.

- The volume of Uzbek exports to China has been estimated at $10 \mathrm{bcm}$ in 2020, on the assumption that most but not all of Lukoil's new production from Kandym-KhauzakShady and South Gissar will be exported to China, and very little other gas. An alternative assumption would be that Lukoil's exports to China will be higher and/or that some Uzbekneftegaz gas will be exported to China.

- It is assumed that all Uzbek sales to Kazakhstan, Kyrgyzstan and Tajikistan are replaced by Turkmen volumes, e.g. in the form of swaps, and in the case of Kazakhstan, subsequently by volumes produced domestically.

- It is assumed that Uzbek gas consumption increases very gradually. This would be the outcome if energy-intensive development policies cancelled out the effect of energysaving policies. It is assumed that the Surgil gas processing plant, which will add 0.8 $\mathrm{bcm} /$ year to aggregate demand, goes ahead by 2020, but not the Uzbekistan GTL plant, which would add $3.5 \mathrm{bcm} /$ year to demand. However Uzbek consumption is perhaps the most uncertain factor in the table. There could be other outcomes, e.g. 
significantly lower consumption due to a shift in government policy towards energy saving, or higher consumption, possibly with imports.

- On Kazakh gas supply, it is assumed that even if there are some further delays at Kashagan, that the project reaches peak output by 2020 .

- On Kazakh demand, it is assumed that the government makes progress towards raising demand, but not all the way to its target. It is assumed that the Tengiz petrochemicals plant will be built by 2020. It is assumed that the Beineu-Shimkent pipeline will be completed, that Kazakhstan will use its own gas for import substitution, and that Turkmen imports will consequently fall by 2020 but that Kazakh exports to China will be at a modest level.

- On Azeri supply, it is assumed that there will be an extra $3 \mathrm{bcm} /$ year of new production from existing or new fields by 2015, and that, in addition to Shah Deniz II, there will be a further increment of $4 \mathrm{bcm} /$ year from new fields by 2020 . Alternative assumptions could be that Shah Deniz II comes on more slowly than planned, and/or that no gas is produced from the other fields before 2020 .

- On demand for Azeri gas, very modest assumptions have been made about demand from Russia. It has been assumed that, given market conditions, it will only rise to 2.5 bcm by 2020, although provisional agreements are already in place for it to rise to 3 bcm by next year. For exports to Turkey, only amounts already agreed upon have been included. An alternative assumption could be that Turkey will hope to source more gas from Azerbaijan.

In conclusion, Table 26 shows the author's projections of exports from Central Asia and the Caspian up to 2020.

Table 26: Central Asian and Caspian Gas Exports 2011-20: projections

\begin{tabular}{|c|c|c|c|c|}
\hline & & 2011 & 2015 & 2020 \\
\hline & To/through Russia*** & 32.6 & 22.8 & 19.3 \\
\hline & To other Central Asia & 4 & 3.9 & 2.1 \\
\hline & To China & 15.5 & 44 & 60 \\
\hline & To Iran** & 8.6 & 11 & 11 \\
\hline & To Georgia & 1.5 & 1.5 & 2 \\
\hline & To Turkey & 6.3 & 5.6 & 13 \\
\hline & To Europe & 0 & 0.7 & 10 \\
\hline & TOTAL & 68.5 & 89.5 & 117.4 \\
\hline & Imports**** & 5.3 & 5.5 & 1.9 \\
\hline & \multicolumn{4}{|c|}{$\begin{array}{l}* \text { contractual/physical } * * \text { including swaps } * * * \text { mostly to } \\
\text { Ukraine } * * * * \text { to the four producer countries (all to } \\
\text { Kazakhstan, aside from } 0.5 \text { Iran to Azerbaijan) }\end{array}$} \\
\hline
\end{tabular}

Source: Table 25 above

The table suggests that China will remain, and grow as, the dominant purchaser of gas exports from the region; that the role of Russia and Ukraine will decline; that Turkey will become a significant importer, overtaking Iran; and that Europe will enter the competition only through purchases from the Shah Deniz project, as and when they go ahead. 


\section{Appendix 1. Statistical and price information}

The availability of information on gas production volumes, trade flows and domestic consumption in the region remains patchy. In compiling the gas balances in Table 1, I drew on a variety of sources, as follows.

For Turkmenistan, where data on production volumes are considered to be state secrets, I extrapolated these from other items in the gas balance, i.e.: domestic consumption (as recorded by the IEA), with the assumption that most of what is recorded as "energy industry own use" is reinjected or flared; and exports (as stated in various published sources, including official Russian and Chinese sources). Turkmenistan does not report its export volumes to the CIS statistical agency, but most of these can be extrapolated from reports by the importers. Turkmen exports to Iran are available from official Iranian sources.

Uzbekistan also treats production data as state secrets. For production (sales gas) and domestic consumption I have used statistics published by the US Energy Information Agency; I have estimated the volumes reinjected and flared on the basis of industry information. Export volumes can mostly be extrapolated from import data published by the CIS statistical agency, press reports, and other published sources.

Kazakhstan presents the biggest statistical puzzle, because there has not been a uniform approach by the energy ministry, state statistics agency and companies to recording (i) the volumes of gas reinjected, and (ii) the volumes exported and either reimported (from the Orenburg processing plant) or swapped. These swap arrangements are discussed in section 4.3. The energy ministry has published information on total production and amounts reinjected and flared, but I have not found any for recent years. But the state statistical agency began in 2009 to publish much fuller information on the gas balance, and I have used the agency's figures for 2006-10 (for production (sales gas), consumption and export) as a starting-point. Estimates, and extrapolations from CIS trade statistics, have been used to complete the balance.

Azerbaijan's state statistical agency publishes data both for total production and production (sales gas). I have used these, together with some published information on domestic consumption and exports.

There is little publicly available information on the prices in cross-border contracts. For gas exported westward, Gazprom's average purchase price in the region is published. For exports to China I have relied on information from Chinese official sources. Other prices, including those in the intra-Central Asian gas trade, are often reported by the local financial press. 


\section{Appendix 2. Changes in trade flows}

Table A1 shows the proportions of trade flows with the most significant trading partners of Central Asian and Caspian countries, i.e. Russia, Ukraine, China, Korea, Turkey, Germany, Italy, France and the US. (Where a country is not listed, it is not among the top ten export destinations or sources of import.)

The main points are that Russia's share of all trade flows fell during the 2000s; the only exception was an increase in its share of imports into Uzbekistan. Ukraine's share fell too, except for small increases in its share of imports into Kazakhstan and Uzbekistan. In contrast, China's share of all trade flows rose, most dramatically in the cases of exports from Turkmenistan (on account of the start-up of gas exports), exports from Uzbekistan, and both exports from and imports to Kazakhstan. Some economists have argued that such statistics understate the role of China in trade in Central Asia, since there is known to be a substantial volume of informal trade. ${ }^{212}$ In Azerbaijan's case the most noticeable change is in the growth of European countries as export destinations: this reflects sales of oil.

\section{Table A1: Selected partners' Shares of Trade}

\begin{tabular}{|c|c|c|c|c|c|c|}
\hline \multicolumn{7}{|l|}{ Turkmenistan } \\
\hline Share of exports, \% & 2000 & 2005 & 2009 & 2010 & 2011 & 2011, \$m \\
\hline Ukraine & 6.6 & 48.7 & 20.8 & 0.8 & 2.0 & 147.6 \\
\hline China & 0.3 & 0.3 & 1.1 & 28.2 & 58.7 & 4266.5 \\
\hline Turkey & 7.4 & 2.9 & 9.5 & 10.4 & 4.9 & 357.0 \\
\hline Italy & 0.0 & 4.0 & 1.8 & 5.3 & 4.6 & 335.3 \\
\hline \multicolumn{6}{|l|}{ Total exports } & 7237.4 \\
\hline Share of imports, \% & 2000 & 2005 & 2009 & 2010 & 2011 & 2011, \$m \\
\hline Russia & 14.2 & 9.4 & 15.9 & 14.1 & 14.1 & 1096.6 \\
\hline Ukraine & 12.0 & 7.8 & 5.5 & 4.1 & 2.9 & 224.8 \\
\hline China & 0.9 & 3.8 & 15.6 & 10.2 & 11.1 & 864.3 \\
\hline Turkey & 14.2 & 7.6 & 16.1 & 22.4 & 21.1 & 1643.4 \\
\hline Germany & 2.9 & 5.6 & 6.1 & 6.5 & 5.8 & 450.9 \\
\hline France & 4.2 & 3.7 & 4.2 & 3.3 & 1.7 & 134.9 \\
\hline US & 3.5 & 9.9 & 5.3 & 0.8 & 1.0 & 77.9 \\
\hline \multicolumn{6}{|l|}{ Total imports } & 7780.7 \\
\hline \multicolumn{7}{|l|}{ Uzbekistan } \\
\hline Share of exports, \% & 2000 & 2005 & 2009 & 2010 & 2011 & 2011, \$m \\
\hline Russia & 27.6 & 23.5 & 15.9 & 24.7 & 20.9 & 1043.8 \\
\hline Ukraine & 7.4 & 5.3 & 30.8 & 1.3 & 3.8 & 187.9 \\
\hline China & 0.5 & 11.7 & 6.6 & 21.2 & 14.7 & 733.4 \\
\hline Turkey & 3.6 & 6.8 & 7.7 & 14.1 & 17.1 & 854.4 \\
\hline US & 1.5 & 2.5 & 1.7 & 1.1 & 0.9 & 46.7 \\
\hline \multicolumn{6}{|l|}{ Total exports } & 4985.4 \\
\hline
\end{tabular}

\footnotetext{
${ }^{212}$ See S.V. Zhukov and O.B. Reznikova, Tsentral'naia Aziia i Kitai: ekonomicheskoe vzaimodeistvie v usloviakh globalizatsii (Moscow: IMEMO RAN, 2009).
} 


\begin{tabular}{|c|c|c|c|c|c|c|}
\hline Share of imports, \% & 2000 & 2005 & 2009 & 2010 & 2011 & 2011, \$m \\
\hline Russia & 14.6 & 26.6 & 22.1 & 21.4 & 21.4 & 2116.6 \\
\hline Ukraine & 6.1 & 4.7 & 5.3 & 2.9 & 3.2 & 314.3 \\
\hline China & 2.1 & 7.1 & 20.3 & 15.2 & 15.1 & 1494.9 \\
\hline Korea & 12.2 & 15.3 & 15.0 & 18.5 & 19.1 & 1891.0 \\
\hline Turkey & 4.4 & 4.7 & 3.6 & 3.6 & 3.9 & 390.2 \\
\hline Italy & 2.5 & 1.9 & 1.9 & 1.5 & 1.6 & 160.5 \\
\hline Germany & 11.3 & 8.8 & 6.1 & 9.0 & 7.4 & 733 \\
\hline US & 8.8 & 2.3 & 1.3 & 1.3 & 1.1 & 110.3 \\
\hline \multicolumn{6}{|l|}{ Total imports } & 9880.4 \\
\hline \multicolumn{7}{|l|}{ Kazakhstan } \\
\hline Share of exports, \% & 2000 & 2005 & 2009 & 2010 & 2011 & 2011, \$m \\
\hline Russia & 17.7 & 12.7 & 8.8 & 4.9 & 5.3 & 3411.1 \\
\hline Ukraine & 2.6 & 0.7 & 5.0 & 1.5 & 1.5 & 954.6 \\
\hline China & 6.8 & 11.5 & 15.5 & 21.1 & 21.7 & 13935.4 \\
\hline Turkey & 0.6 & 2.2 & 3.3 & 4.7 & 2.8 & 1814.1 \\
\hline Italy & 9.3 & 9.2 & 4.6 & 4.3 & 5.2 & 3319.7 \\
\hline Germany & 5.6 & 12.3 & 7.8 & 9.5 & 8.3 & 5352.6 \\
\hline France & 0.2 & 8.9 & 8.4 & 7.5 & 9.4 & 6061.4 \\
\hline US & 2.1 & 4.6 & 4.0 & 3.7 & 2.4 & 1559.8 \\
\hline \multicolumn{6}{|l|}{ Total Exports } & 64195.1 \\
\hline Share of imports, \% & 2000 & 2005 & 2009 & 2010 & 2011 & 2011, \$m \\
\hline Russia & 48.3 & 35.6 & 29.7 & 18.7 & 20.0 & 6969.2 \\
\hline Ukraine & 1.6 & 3.6 & 4.8 & 4.8 & 5.0 & 1750.4 \\
\hline China & 3.0 & 21.3 & 26.2 & 34.1 & 30.2 & 10517.1 \\
\hline Korea & 1.7 & 1.5 & 1.0 & 2.2 & 2.4 & 833.0 \\
\hline Turkey & 2.9 & 2.5 & 2.1 & 3.0 & 3.0 & 1043.1 \\
\hline Italy & 3.1 & 2.8 & 5.6 & 4.8 & 3.2 & 1124.5 \\
\hline Germany & 6.6 & 7.1 & 6.2 & 6.5 & 7.4 & 2582.8 \\
\hline France & 1.5 & 3.2 & 2.2 & 1.2 & 1.2 & 404 \\
\hline US & 5.5 & 2.9 & 2.0 & 2.7 & 2.6 & 908.2 \\
\hline \multicolumn{6}{|l|}{ Total imports } & 34770.0 \\
\hline \multicolumn{7}{|l|}{ Azerbaijan } \\
\hline Share of exports, \% & 2000 & 2005 & 2009 & 2010 & 2011 & 2011, \$m \\
\hline Russia & 5.6 & 6.6 & 5.1 & 3.6 & 1.7 & 506.2 \\
\hline Turkey & 6.0 & 6.3 & 0.7 & 0.8 & 0.8 & 238.4 \\
\hline Italy & 43.7 & 30.3 & 25.8 & 33.0 & 32.4 & 9655.1 \\
\hline Germany & 0.5 & 0.8 & 0.6 & 0.0 & 6.2 & 1864.8 \\
\hline France & 11.8 & 9.4 & 9.0 & 8.7 & 13.2 & 3929.4 \\
\hline US & 0.5 & 1.0 & 11.9 & 8.0 & 7.5 & 2247.6 \\
\hline \multicolumn{6}{|l|}{ Total exports } & 29843.6 \\
\hline Share of imports, \% & 2000 & 2005 & 2009 & 2010 & 2011 & 2011, \$m \\
\hline Russia & 21.3 & 17.0 & 17.5 & 17.4 & 15.5 & 1941.6 \\
\hline Ukraine & 3.1 & 5.4 & 8.4 & 7.1 & 4.6 & 579.9 \\
\hline China & 2.0 & 4.1 & 7.9 & 8.9 & 7.8 & 981.5 \\
\hline Turkey & 11.0 & 7.4 & 14.8 & 11.7 & 18.1 & 2271.4 \\
\hline Italy & 2.4 & 2.2 & 2.1 & 1.8 & 4.2 & 531.3 \\
\hline Germany & 5.8 & 6.1 & 9.1 & 9.2 & 7.2 & 901.7 \\
\hline US & 10.0 & 3.4 & 4.3 & 3.1 & 2.9 & 361.2 \\
\hline \multicolumn{6}{|l|}{ Total imports } & 12548.8 \\
\hline
\end{tabular}

Source: Asian Development Bank, Key Indicators for Asia and the Pacific 2012, author's calculations 


\section{Appendix 3. Turkmenistan: export revenues and their contribution to the economy}

Estimates of hydrocarbons export revenues, 2005-2011

The IMF publishes estimates of the value both of Turkmenistan's total exports and of its hydrocarbons exports, making use of information reported directly to it by the Turkmen authorities but not published. The IMF takes into account these statistics, and other information supplied by the Turkmen authorities, in calculating GDP growth estimates and projections for Turkmenistan.

The author's estimates of Turkmenistan's earnings from hydrocarbons exports are based on statistics published by the International Energy Agency (IEA), and market information. To estimate volumes of natural gas exports, and the prices charged, market information, including statements by importing companies; for crude oil, volumes reported by the IEA and the average Russian export price as a proxy; for oil products, volumes reported by the IEA and the average Eurasian market price quoted by Bloomberg.

Table A2 compares the IMF's estimates of hydrocarbons revenues to mine, and shows substantial differences.

In 2005-07, the author's estimates of export revenues (which reflect market perception) were higher than the IMF's. For 2008 the author's estimates were lower than the IMF's, and in 2009 they were substantially lower (by nearly one third). The IMF's projections for hydrocarbons revenues in 2010 are higher than the author's, by about one quarter, and for 2011 substantially higher, by considerably more than one third. This means that either the market (price perceptions in which have guided the author's estimates) has seriously miscalled Turkmen export prices, or that the IMF's understanding of the level of hydrocarbons revenues, sourced from the national statistical agency, has - particularly during and after the economic crisis and the 2009 dispute with Russia - been overstated.

The impact of the Russian cutback on Turkmen export revenues, according to the author's estimates, was cushioned by several factors. First, market information (including in this case, statements and hints from Gazprom management and the Russian government) indicates that when the gas was still flowing in the first quarter of 2009, a very high price was being paid. So although exports for the year only totalled $11.8 \mathrm{bcm}$, revenues were $\$ 3.776$ billion.

In 2010, gas export revenues fell significantly: only $11 \mathrm{bcm}$ was exported during the whole year, but at lower prices, giving an estimated revenue of $\$ 2.2$ billion. However the effect was cushioned by strong oil and oil products prices, which meant that sales of these commodities made up much of the loss on gas sales.

When information becomes available for 2011-12, increased gas export revenues from sales to China are sure to change the picture substantially, while strong sales of oil and oil products will also play a part. 
Table A2: Turkmenistan Gas and Oil Exports

\begin{tabular}{|c|c|c|c|c|c|c|c|c|}
\hline & & 2005 & 2006 & 2007 & $\begin{array}{r}2008 \\
\text { (prelim) }\end{array}$ & $\begin{array}{r}2009 \\
\text { (prelim) }\end{array}$ & $\begin{array}{r}2010 \\
\text { (proj) }\end{array}$ & $\begin{array}{r}2011 \\
\text { (proj) }\end{array}$ \\
\hline \multirow{2}{*}{$\begin{array}{l}\text { Export of } \\
\text { hydrocarbons }\end{array}$} & \$m, IMF statistics & 4198 & 6228 & 8093 & 11007 & 8419 & 8958 & 11200 \\
\hline & \$m, OIES estimates & 5079.6 & 7108.9 & 9404 & 9234.2 & 5742.8 & 7267.8 & 7064.9 \\
\hline \multirow{3}{*}{$\begin{array}{l}\text { Export of gas } \\
\text { to Russia and } \\
\text { Ukraine }\end{array}$} & Volume bcm, estimate & 39.49 & 41.0 & 43.2 & 42.3 & 11.8 & 11 & 11 \\
\hline & price, estimate, $\$ / \mathrm{mcm}$ & $\begin{array}{l}44- \\
60^{*}\end{array}$ & 65 & 100 & $\begin{array}{l}130 \\
150 * *\end{array}$ & $\begin{array}{l}320 \\
(\mathrm{q} 1)^{* * *}\end{array}$ & 200 & 200 \\
\hline & $\begin{array}{l}\text { revenue, estimate, } \\
\text { \$m }\end{array}$ & $\begin{array}{r}1480 \\
+ \\
\text { barter }\end{array}$ & 2665 & 4320 & 5922 & 3776 & 2200 & 2200 \\
\hline \multirow{3}{*}{$\begin{array}{l}\text { Export of gas } \\
\text { to Iran }\end{array}$} & bcm, estimate & 5.81 & 5.3 & 8 & 7 & 7 & 8 & 8 \\
\hline & price, est., $\$ / \mathrm{mcm}$ & 42 & $65 \#$ & 75 & $130-150$ & 120 & 120 & 120 \\
\hline & $\begin{array}{l}\text { revenue, estimate, } \\
\text { \$m }\end{array}$ & 244.02 & 332.31 & 600 & 980 & 840 & 960 & 960 \\
\hline \multirow{3}{*}{$\begin{array}{l}\text { Export of gas } \\
\text { to China }\end{array}$} & bcm, estimate & 0 & 0 & 0 & 0 & 0 & 3.9 & 13 \\
\hline & price, est., $\$ / \mathrm{mcm}$ & & & & & & 160 & 180 \\
\hline & $\begin{array}{l}\text { revenue, estimate, } \\
\text { \$m }\end{array}$ & & & & & & 624 & 2340 \\
\hline \multirow{3}{*}{$\begin{array}{l}\text { Exports of } \\
\text { crude oil }\end{array}$} & IEA, 000 tonnes & 2510 & 1500 & 1900 & 2400 & 2400 & 2400 & 2400 \\
\hline & $\begin{array}{l}\text { avg Rus. export price, } \\
\text { \$/tonne }\end{array}$ & 331.32 & 411.95 & 472.05 & 668.50 & 411.95 & 535.09 & 549.75 \\
\hline & $\begin{array}{l}\text { revenue, estimate, } \\
\text { \$m }\end{array}$ & 831.61 & 617.92 & 896.89 & 1604.40 & 988.68 & 1284.22 & 1319.40 \\
\hline \multirow{3}{*}{$\begin{array}{l}\text { Exports of } \\
\text { motor } \\
\text { gasoline }\end{array}$} & IEA, 000 tonnes & 555 & 661 & 640 & 672 & 650 & 650 & 650 \\
\hline & $\begin{array}{l}\text { avg Eurasian mkt } \\
\text { price, \$/tonne }\end{array}$ & 570.09 & 639.84 & 711.3 & 869.6 & 605.53 & 767.66 & 780 \\
\hline & $\begin{array}{l}\text { revenue, estimate, } \\
\text { \$m }\end{array}$ & 316.4 & 422.93 & 455.23 & 584.37 & 393.59 & 498.98 & 507 \\
\hline \multirow{3}{*}{$\begin{array}{l}\text { Exports of } \\
\text { diesel oil }\end{array}$} & IEA, 000 tonnes & 1645 & 1959 & 1897 & 1992 & 1900 & 1900 & 1900 \\
\hline & $\begin{array}{l}\text { avg Eurasian mkt } \\
\text { price, \$/tonne }\end{array}$ & 507.87 & 580.37 & 637.84 & 920.75 & 522.2 & 673.86 & 690 \\
\hline & $\begin{array}{l}\text { revenue, estimate, } \\
\text { \$m }\end{array}$ & 835.45 & 1136.9 & 1210 & 1834.1 & 992.18 & 1280.3 & 1311 \\
\hline \multirow{3}{*}{$\begin{array}{l}\text { Exports of } \\
\text { heavy fuel oil }\end{array}$} & IEA, 000 tonnes & 815 & 971 & 940 & 987 & 950 & 950 & 950 \\
\hline & $\begin{array}{l}\text { avg Eurasian mkt } \\
\text { price, } \$ / \text { tonne }\end{array}$ & 229.56 & 287.2 & 340.3 & 461.33 & 345.62 & 442.35 & 450 \\
\hline & $\begin{array}{l}\text { revenue, estimate, } \\
\text { \$m }\end{array}$ & 187.09 & 278.87 & 319.88 & 455.33 & 328.34 & 420.23 & 427.5 \\
\hline
\end{tabular}




\section{Estimates of economic growth}

There are some doubts about the assumptions by the IMF and other international financial institutions about Turkmen GDP growth in 2009 and 2010, when Turkmenistan's main export trade - natural gas sales to Russia - had been sharply reduced, and not yet replaced by sales to China. The abrupt disruption of any country's largest export trade would normally bring serious economic problems. And yet, counter-intuitively, the IMF and other international financial institutions forecasted record-breaking economic growth in Turkmenistan in 2010 and substantial growth in 2011. Although the IMF later revised its forecasts downwards, it continues to record and to project rapid economic growth: its most recent figures record GDP growth (preliminary) of 10.5\% in 2008, 6.1\% in 2009 and (projected) $9.4 \%$ in 2010 and $11.5 \%$ in 2011.

It has been shown above that the IMF may be overestimating Turkmenistan's revenues from hydrocarbon exports. It appears that its growth figures do not fully reflect the cutback of exports to Russia, which had a substantial impact on Turkmenistan's state finances both in 2009 and in 2010. In addition, there are other unexplained elements in the IMF's projections of economic growth.

As for the future, Turkmenistan probably had sufficient resources accumulated during the years of rising oil and gas prices (2002-08) to see its economy through the recession of 200809 without any serious problems. From 2012, revenue from sales to China will replace most, if not all, of future sales to Russia that may be lost.

Table A3 shows the IMF's estimates of GDP growth and nominal GDP in dollars, together with its estimates of export revenues, and hydrocarbons export revenues. (the level of which is discussed above). The estimates of revenues are presented as a proportion of GDP, in order to show the crucial role that these revenues play in the economy. The hydrocarbons revenues comprise the vast bulk of total revenues from the export of goods, and, according to the IMF's statistics, have in recent years been equal to between $24 \%$ and $58 \%$ of GDP.

Table A3: Turkmenistan GDP and Export Revenues: IMF statistics

\begin{tabular}{|c|c|c|c|c|c|c|c|c|}
\hline & & 2005 & 2006 & 2007 & $\begin{array}{l}2008 \\
\text { (prelim) }\end{array}$ & $\begin{array}{l}2009 \\
\text { (prelim) }\end{array}$ & $\begin{array}{l}2010 \\
\text { (proj) }\end{array}$ & $\begin{array}{l}2011 \\
\text { (proj) }\end{array}$ \\
\hline \multirow{2}{*}{ GDP } & enmulobonom o/ & $120 /$ & $11.10 /$ & $1160 /$ & 1050 & 6106 & $040 \%$ & $1150 /$ \\
\hline & nominal s hillion & 172 & 214 & 260 & 190 & 185 & 199 & 235 \\
\hline & & & & & & & & \\
\hline \multirow[t]{2}{*}{ Export of goods } & \$ million & 4944 & 7155 & 9114 & 11786 & 8946 & 9502 & 11765 \\
\hline & as \% of GDP & $28.7 \%$ & $33.4 \%$ & $35.1 \%$ & $62.0 \%$ & $48.4 \%$ & $47.7 \%$ & $50.1 \%$ \\
\hline \multirow{3}{*}{$\begin{array}{l}\text { Export of } \\
\text { hydrocarbons }\end{array}$} & & & & & & & & \\
\hline & \$ million & 4198 & 6228 & 8093 & 11007 & 8419 & 8958 & 11200 \\
\hline & as \% of GDP & $24.4 \%$ & $29.1 \%$ & $31.1 \%$ & $57.9 \%$ & $45.5 \%$ & $45.0 \%$ & $47.7 \%$ \\
\hline
\end{tabular}

Source: IMF World Economic Outlook and Regional Economic Outlook; author's calculations (of percentages)

Although the IMF estimates hydrocarbons revenues in 2009 and 2010 at a higher level than the author does, it does acknowledge that they were considerably lower than in 2008. What, then, accounts for its bullish figures for GDP growth: 6.1\% (preliminary) for 2009, 9.4\% (projected) for 2010 and $11.5 \%$ (projected) for 2011? (These figures, in the IMF Regional 
Economic Outlook of October 2010, have been revised from those published a year earlier, when the IMF projected GDP growth of $4 \%$ in 2009 and $15.3 \%$ in 2010.)

(i) construction. The Turkmen statistical agency states on its web site ${ }^{213}$ that in 2009 investment in building works by Turkmen ministries was 2.3 times higher than in 2008; in 2010 it grew, but at a fraction of the pace - only by $12 \%$ compared to 2009 . A list of industrial production gains in 2010 states that the production of semi-fabricated steel products used in construction grew faster than any other type of product, i.e. five times over between 2009 and 2010. It is difficult to know what to conclude from this but, as any visitor to Ashgabat knows, a large amount of building work - some of it of dubious value - is in progress.

(ii) the IMF records substantial economic growth in 2008, despite the fact that the nominal GDP figure given in the Regional Economic Outlook is lower than in 2007 - and although there was a substantial change in the exchange rate, it cannot be explained by that alone.

(iii) There is a gigantic discrepancy between the IMF's figures for nominal GDP in dollars, and the figures I have extrapolated from the EBRD's statistics. Indeed in 2006 and 2007, the IMF's economists considered that the Turkmen economy was more than twice the size that their EBRD colleagues believed it to be. These discrepancies, shown in Table A4, indicates just how much uncertainty is involved in the calculation of GDP. This in turn suggests that projections based on the statistics should be treated with a large measure of scepticism.

Table A4: Turkmenistan GDP: IMF and EBRD views compared

\begin{tabular}{|c|c|c|c|c|c|c|c|c|}
\hline & & 2005 & 2006 & 2007 & $\begin{array}{l}2008 \\
\text { (prelim) }\end{array}$ & $\begin{array}{l}2009 \\
\text { (prelim) }\end{array}$ & $\begin{array}{l}2010 \\
\text { (proj) }\end{array}$ & $\begin{array}{l}2011 \\
\text { (proj) }\end{array}$ \\
\hline \multirow{2}{*}{$\begin{array}{l}\text { GDP (IMF } \\
\text { statistics) }\end{array}$} & annual $\%$ change & 13 & 11.4 & 11.6 & 10.5 & 6.1 & 9.4 & 11.5 \\
\hline & nominal, \$ billion & 17.2 & 21.4 & 26.0 & 19.0 & 18.5 & 19.9 & 23.5 \\
\hline \multirow{3}{*}{$\begin{array}{l}\text { GDP (EBRD } \\
\text { statistics) }\end{array}$} & annual $\%$ change & 13.0 & 11.4 & 11.6 & 10.5 & 6.1 & 11.0 & $\mathrm{n} / \mathrm{a}$ \\
\hline & \$ bn (author's calc'n) & 8.3 & 10.4 & 12.7 & 17.3 & 18.2 & $\mathbf{n} / \mathbf{a}$ & $\mathbf{n} / \mathbf{a}$ \\
\hline & billion manats & $91,863.2$ & $113,073.6$ & $136,244.0$ & $247,152.0$ & 52.7 & 56.6 & $\mathrm{n} / \mathrm{a}$ \\
\hline \multirow[t]{2}{*}{ Exchange rate } & end year, EBRD & $10,870.0$ & $10,690.0$ & $10,690.0$ & $14,250.0$ & 2.9 & $\mathrm{n} / \mathrm{a}$ & $\mathrm{n} / \mathrm{a}$ \\
\hline & annual average, EBRD & $11,015.2$ & $10,881.9$ & $10,690.0$ & $13,041.5$ & 2.9 & $\mathrm{n} / \mathrm{a}$ & $\mathrm{n} / \mathrm{a}$ \\
\hline
\end{tabular}

Note: The new Turkmen manat was introduced in 2009, producing a sharp change in the exchange rate

Whatever the real rate of economic growth was in 2008-11, it must be acknowledged that in subsequent years a central factor will be the growth of gas exports to China, discussed throughout this paper.

${ }^{213}$ See the Turkmenistan statistics agency web site, www.stat.gov.tm 


\section{Foreign exchange reserves}

It seems likely that Turkmenistan, like other hydrocarbons exporters, will have relied partly on foreign exchange reserves accumulated before the economic crisis to cushion the effect of the crisis - which for Turkmenistan was transmitted through the medium of the Russian cutback of gas purchases.

Under the presidency of Saparmurat Niyazov, in 1996, Turkmenistan established a State Fund for the Development of the Oil and Gas Industry and Mineral Resources (SFDOG) and a larger Foreign Exchange Reserve Fund (FERF). Both were under the personal control of the president and not required to publish accounts. Turkmenistan was criticised by international organisations including Global Witness for this lack of transparency. ${ }^{214}$

While the level of the Foreign Exchange Reserve Fund remained unknown, information was published about the total level of foreign exchange reserves, including the central bank's reserves, as follows:

Table A5: Turkmenistan: foreign exchange reserves and external debts

\begin{tabular}{|l|r|r|r|r|r|r|r|}
\hline & 2003 & 2004 & 2005 & 2006 & 2007 & 2008 & 2009 \\
\hline $\begin{array}{l}\text { Reserves, excluding gold, } \\
\text { \$m }\end{array}$ & $2,673.0$ & $2,714.0$ & $3,442.0$ & $8,059.0$ & $13,222.0$ & $16,713.0$ & $18,960.0$ \\
\hline External debt stock, \$m & $1,519.0$ & $1,273.0$ & $1,007.0$ & 805.0 & na & na & na \\
\hline External debt/GDP (\%) & 25.7 & 18.2 & 12.1 & 7.9 & 2.4 & 3.2 & 2.7 \\
\hline
\end{tabular}

Source: EBRD selected economic indicators

(http://www.ebrd.com/pages/research/economics/data/macro.shtml\#macro, downloaded February 2011)

Note: the "reserves, excluding gold" data includes foreign exchange reserves of the central bank plus the foreign exchange reserve fund.

These statistics suggest that in 2009, the last year for which information is available, Turkmenistan had foreign exchange reserves of $\$ 18.96$ billion, equivalent to more than 25 months' imports. Some of these funds may have been used to help Turkmenistan through the crisis caused by the reduction of exports to Russia.

In 2010, Turkmenistan reported both to the IMF and to the EBRD that a new Stabilisation Fund had been established in October 2008, in which excess hydrocarbons revenues would be invested for medium-term and future use in the national interest. A Public Information Notice issued in November 2010 by the IMF after its regular ("Article IV") consultation with the Turkmen authorities called for extra-budgetary funds to be consolidated into the budget, and said that the new fund's objectives and operations "should be set according to best international practice". It stated that the use of Stabilisation Fund resources for extra budgetary projects "should be phased out", although no information was given about the extent of such use of the fund nor of its total size. The EBRD's Transition Report of November 2010 reported that the European Union was working with Turkmenistan on "an intensive fiscal advisory programme" following the establishment of the fund. The fund's reserves would "help fund medium-term infrastructure investments, although relevant investment rules have yet to be disclosed", the EBRD stated. ${ }^{215}$

Loans

\footnotetext{
${ }^{214}$ Kalyuzhnova and Kaser, (2005)

${ }^{215}$ IMF Public Information Notice no. 10/146, "IMF Executive Board Concludes 2010 Article IV Consultation with Turkmenistan”, 5 November 2010; EBRD, Transition Report 2010, p. 151.
} 
Loans from China for the development of the South Yolotan gas field that have been publicly reported amount to $\$ 8.1$ billion: a $\$ 4$ billion loan from the China Development Bank to Turkmengaz in June 2009, a a further $\$ 4.1$ billion loan from the China Development Bank to Turkmengaz in April 2011. According to Chinese official sources, $100 \%$ of repayments on the 2009 loan will be taken in the form of gas exports. However the repayment curve on the loan is unknown, i.e. it is unknown when the repayments will start and what their level will be in different years. ${ }^{216}$ Since the repayment terms of the loans are unknown, it is difficult to know what the economic effect will be. In the next few years this factor will reduce the economic benefit to Turkmenistan of gas export revenues. Nevertheless, given Turkmenistan's size, population and budget requirements, and its overall debt position, this is unlikely to cause a fiscal crisis.

\section{Conclusions}

The IMF's estimates for hydrocarbons revenues in 2008-09, and its projections for 2010-11, are inexplicably high. The cutback of exports to Russia had a substantial impact on Turkmenistan's state finances both in 2009 and in 2010. In addition to problems with the stated hydrocarbons export revenues, there are other unexplained elements in the IMF's projections of economic growth.

As for the future, Turkmenistan probably had sufficient resources accumulated during the years of rising oil and gas prices (2002-08) to see its economy through the recession of 200809 without any serious problems, and revenue from sales to China will replace most, but probably not all, of future sales that may be lost to Russia - although the lack of transparency of export prices, and concerning the repayment of China's substantial loans to Turkmengaz, make it impossible to assess the economic effect of these gas sales in any detailed way.

\footnotetext{
${ }^{216}$ State News Agency of Turkmenistan, "World economies count on Turkmen gas", 28 April 2011, turkmenistan.gov.tm; Turkmenistan.ru web site, "Turkmenistan will raise extra US \$4.1 billion”, 27 April 2011; Reuters, "China in Central Asia: latest investments", 11 March 2010.
} 


\section{Appendix 4. Production from projects in Uzbekistan with Gazprom participation}

Table A6 shows the shares held by Gazprom Germania (a 100\% Gazprom subsidiary) in production projects in Uzbekistan. It is based on information published by Gazprom Germania for 2010; its 2011 management report stated only that it continues to participate in exploration and production in Central Asia via Gas Project Development Central Asia.

Table A6: Production from Uzbekistan Projects with Gazprom Participation, 2010

\begin{tabular}{|c|c|c|c|c|c|}
\hline Project & $\begin{array}{l}\text { Gazprom Germania share in } \\
\text { project }\end{array}$ & $\begin{array}{l}\text { Total } \\
\text { output, } \\
\text { bcm }\end{array}$ & $\begin{array}{l}\text { GG } \\
\text { share, } \\
\text { bcm }\end{array}$ & $\begin{array}{l}\text { Total } \\
\text { export, } \\
\text { bcm }\end{array}$ & $\begin{array}{l}\text { GG } \\
\text { share of } \\
\text { export, } \\
\text { bcm }\end{array}$ \\
\hline Kokdumalak & $\begin{array}{l}12.5 \% \text { (via GPD, which has } \\
25 \%)\end{array}$ & $4.0^{*}$ & 0.500 & 2.4 & 0.300 \\
\hline Gissarneftegaz & 20\% (via GPD, which has 40\%) & 4.1 & 0.820 & 1.7 & 0.340 \\
\hline Shakhpakhty & $\begin{array}{l}37.5 \% \text { (12.5\% via GPD, which } \\
\text { has } 25 \% \text {, and } 25 \% \text { via } \\
\text { Gazpromzarubezhneftegaz) }\end{array}$ & 0.2 & 0.075 & $0.2^{* *}$ & 0.075 \\
\hline \multicolumn{2}{|l|}{ Total } & 8.3 & 1.395 & 4.3 & 0.715 \\
\hline \multicolumn{6}{|c|}{$\begin{array}{l}\text { GPD }=\text { Gas Project Development Central Asia Ltd, owned } 50 \% \text { by Gazprom Germania and } 50 \% \\
\text { by Centrex Energy \& Gas of Germany }\end{array}$} \\
\hline \multicolumn{6}{|c|}{ Gazpromzarubezhneftegaz $=100 \%$ Gazprom subsidiary } \\
\hline \multicolumn{6}{|c|}{$\begin{array}{l}\text { * This is an estimate. Gazprom Germania states that } 6.0 \mathrm{bcm} \text { of associated gas is "processed for } \\
\text { industrial and technical use"; there is a high level of reinjection at this field }\end{array}$} \\
\hline \multicolumn{6}{|c|}{ ** It is assumed from industry information that all Shakhpakhty production is exported } \\
\hline
\end{tabular}




\section{Appendix 5. Gas supply problems in Uzbekistan}

The assumption that some parts of Uzbekistan are suffering very severe gas supply problems in winter is difficult to verify, and it is impossible to judge the extent of the problems accurately. The only source of information I have found is reports by reliable news organisations based outside Uzbekistan. Some of these are summarised here.

\section{May 2010}

Journalists who travelled to Andizhan in the Ferghana Valley were told that throughout the winter there had been no gas supply for weeks on end, and that electricity had only been available from 05.00 to 13.00 and from 17.00 to 18.00 . During their ten-day visit they collected information about four explosions in apartment blocks, caused by people attempting to divert to their homes gas that they considered was being unfairly directed elsewhere.

\section{January 2011}

The town of Margilan in the Ferghana valley had had no gas supplied since November 2010, it was reported. In Kokand, pressure in distribution networks was so low that gas was to all intents and purposes unavailable for most consumers. A programme of infrastructure upgrades was in progress but had yet to produce results

\section{November 2011}

There were reported warnings of extensive gas and power cuts, followed by reports of cuts, in the Rishtanskyi, Altyaryksky, Buvaidiiskyi and Bagdadsky districts in the Ferghana Valley. In Sokhsky district gas had been cut off, reportedly due to higher-than-planned use in districts of Kyrgyzstan served by the same infrastructure. (All these areas had been subjected to 20+ hours a day electricity cuts since the mid 1990s.) The head of the Ferghana valley administration was dismissed by presidential decree on 7 November.

In Tashkent, the capital of Uzbekistan, the adminstration of the Almazarskii district was reported to have distributed announcements to industrial and residential customers urging them to limit their consumption of gas and electricity.

In the Syrdarya region, a demonstration by residents at the town hall, demanding restoration of gas supplies, was reported. The town of Urgench was reported to have had no gas supplied for "nearly a month", and to be suffering regular unscheduled electricity cuts. More serious problems than usual were also reported in Samarkand region: in the city of Samarkand it was reported that there was no gas supply, and electricity only every other day. There were reports from Dzhizhakskaia region that most businesses were using coal and wood as fuel, in the absence of gas. ${ }^{217}$

\footnotetext{
${ }^{217}$ Sources: “Andizhan pod ‘mudrym rukovodstvom’ Islama Karimova”, Ferghana News, 27 May 2010; “Uzbekistan: zhiteli Margilana snova ostalis’ bez gaza”, Ferghana News, 9 January 2011; “Uzbekistan: Islam Karimov smenil glavu administratsii Ferganskoi oblasti”, Ferghana News, 8 November 2011; "Uzbekistan: zhiteliam Ferganskoi oblasti rekomandovano zapastis'm drovami i uglem”, Ferghana News, 9 November 2011; "V Uzbekistane nekhvatka gaza grozit sotsial'nym vsryvom", Rosbalt.ru, 11 November 2011; "Byt i oil opredeliaiut soznanie", Uzmetronom news agency, 14 November 2011; "Uzbekistan: k 20-letiiu nezavisimosti my ostalis' bez gaza i sveta", Ferghana News, 23 November 2011; "Postavki uzbekskogo gaza v Kazakhstan sushchestvenno snizheny", Ferghana News, 15 November 2011
} 


\section{Bibliography}

\section{Official and government documents and statistics}

Agenstvo respubliki Kazakhstan po statistike, Toplivno-energeticheskii balans respubliki Kazakhstan 2009 (Astana, 2010)

Azerbaijan Ministry of Economy web site www.economy.az

AzStat, Foreign Trade of Azerbaijan 2011 (Baku, 2011)

Hrant Bagratian and Emine Gurgen, IMF Working Paper: Payments Arrears in the Gas and Electric Power Sectors of the Russian Federation and Ukraine (December 1997)

BP Statistical Review of World Energy - June 2012

British embassy in Turkmenistan, Updates on the Energy Sector

Cedigaz, Natural Gas in the World: 2012 Edition

John Dodsworth, Paul Mathie and Clinton Shiells, IMF Policy Discussion Paper: CrossBorder Issues in Energy Trade in the CIS Countries (December 2002)

EBRD Transition Report 2010

European Commission, On security of energy supply and international cooperation: "The EU Energy Policy: Engaging with Partners Beyond Our Borders" (COM (2011) 539), 7 September 2011

Global Gas Flaring Initiative web site http://web.worldbank.org/WBSITE/EXTERNAL/TOPICS/EXTOGMC/EXTGGFR/0,,menu PK:578075 pagePK:64168427 piPK:64168435 theSitePK:578069,00.html

IEA World Energy Outlook 2010

IMF 2012 Article IV Report: Republic of Kazakhstan

Kazakhstan ministry of oil and gas web site < http://mgm.gov.kz/>

National statistical agency of Uzbekistan. <http://www.stat.uz/>

Postanovlenie Prezidenta respubliki Uzbekistan, 8 June 2010, no. PP-1351;

Programma po razvitiiu neftegazovogo sektora v Respublike Kazakhstan na 2010-2014 gody, approved by presidential decree no. 1072, 18 October 2010

State information agency of Turkmenistan, "2010 god v letopisi epokhi novogo vozrozhdeniia", 13 January $2011<$ http://tdh.gov.tm/?id=2426> 
Turkmenistan statistics agency web site, <www.stat.gov.tm>

Ukaz prezidenta Turkmenistana o bezvozmezdnom predostavlenii naseleniiu Turkmenistana prirodnogo gaza, 15 August 2003

UNDP Kazakhstan, Human Development Report 2009

UNFCCC clean development mechanism web site $<$ http://ji.unfccc.int $>$

US Energy Information Administration web site < http://www.eia.gov/>

US State Department, "Deputy Assistant Secretary for Central Asia Susan Elliott's Remarks for Turkmenistan International Oil and Gas Conference", 17 November 2010, Ashgabat

World Bank, Azerbaijan: issues and options associated with energy reform (report no. 32371-AZ), 31 March 2005

Zakon respubliki Kazakhstan "O gaze i gazosnabzhenii" (law no. 532-IV signed by the president on 9 January 2012);

\section{Company materials and web sites}

Agreement on the Joint Development and Production Sharing for the Azeri and Chirag Fields and the Deep Water Portion of the Gunashli Field in the Azerbaijan Sector of the Caspian Sea

Bernstein Research, The Caspian: Cradle of Oil Production Can Rock World Output (New York, January 2011)

BMI, Turkmenistan Oil \& Gas Report Q1 2012

BP web site $<$ http://www.bp.com/ $>$

Caspian Drilling Co. web site $<$ http://www.caspiandrilling.com/index.php $>$

Chemicals-Technology web site $<$ http://www.chemicals-technology.com $>$

CNPC web site $<$ http://www.cnpc.com.cn>

Dragon Oil Annual Reports and interim reports

ENI web site $<$ http://www.eni.com/>

Gazprom, Annual Report 2011

Gazprom web site <http://gazprom.com/>

Gazprom investor day presentation, Gaining Momentum, February 2010

Gazprom Germania Management Report for 2010

Halyk finance research notes

IHS Cera, Caspian Development Corporation: Final Implementation Report (December 2010) 
Kazgermunai web site $<$ http://www.kazgermunay.kz/>

Kazmunaigaz, Godovoi otchet 2009

Kazmunaigaz, Godovoi Otchet 2010

Kazmunaigaz Annual Report 2011

Kazmunaigaz web site $<$ http://www.kmg.kz/>

Kazmunaigaz E\&P Annual Report 2011

Kazrosgaz website $<$ http://www.kazrosgas.org

Kaztransgaz Godovoi otchet 2010

KPO, Otchet ob ustoichivom razvitii za 2009 god

KPO, Otchet ob ustoichivom razvitii za 2010 god

Lukoil Annual Report 2011

Lukoil Overseas Holding Ltd, Corporate Report 2010

Hedayat Omidvar (National Iranian Gas Company), Iranian Gas Prospect (slide presentation, 2008)

PetroChina, Connected Transaction: Acquisition of Rights Under Product Sharing Contract (Hong Kong stock exchange filing);

PetroKazakhstan corporate brochure

PFC Energy Russia and Caspian Service memorandum, Kazakhstan: China Gas Route May Be Delayed, 30 July 2012

Presentation by Lu Gongxun, General Director, CNPC Turkmenistan,TIOGE 2011

Presentation by Oraz Orazov, Director, Nebitgazylmytaslama Institute, Turkmenistan International Oil and Gas Exhibition (TIOGE) 2011

Presentation by Abdubakhram Vakilov, Asia Transgaz, at Oil and Gas Uzbekistan conference, May 2012, Tashkent

Presentation by Sherzod Akhudjanov, Neftegazinvest, at the Oil Gas Uzbekistan conference (OGU), May 2012, Tashkent

Presentation by Bertrand Chevalier, Total, at the Caspian Oil and Gas conference, May 2012, Baku 
Presentation by Khoshbakht Yusifzade, vice-president of Socar, at the Caspian Oil and Gas Conference, Baku, May 2012Presentation by Christian Guidicelli of Total at the Caspian Gas Forum, July 2012, Istanbul.

Presentations by Jim Gillett, GCA, at TIOGE 2010 and 2011

Presentation by Neftegazinvest at the Oil and Gas Uzbekistan conference, May 2012, Tashkent

Presentation by Simone Bonetti, Technip, at the Oil and Gas Uzbekistan conference, May 2012, Tashkent

Socar Annual Report 2010

Socar web site $<$ http://new.socar.az $>$

Statoil web site $<$ http://www.statoil.com $>$

Stroitransgaz web site $<$ http://www.stroytransgaz.ru $>$

Tengizchevroil Annual Report 2011

Tengizchevroil web site $<$ http://www.tengizchevroil.com/>

Tethys Petroleum, Introduction to the Official List (for trading on the London Stock Exchange)

Tethys Petroleum Ltd, Management's Discussion and Analysis, 30 June 2012; Tethys company presentations

Tethys Petroleum web site <http://www.tethyspetroleum.com/ $>$

Urikhtau Operating web site $<$ http://www.urikhtau.kz/>

Uzbekneftegaz web site $<$ www.ung.uz/ru/ $>$

Uzbekneftegaz, Ekonomicheskoe obozrenie no. 11 (133), November 2010

$<\mathrm{http}$ //www.ung.uz/ru/press_center/smi/econom_11_2010>

Uz-Kor Chemical, UZB: Surgil Natural Gas Chemicals. Environmental Impact AssesmentPart 1 .

ZMB (Schweiz) Annual Report 2007

ZMB (Schweiz) Annual Report 2008 


\section{Newspapers, magazines and news agencies}

Agenstvo neftegazovoi informatsii (Samotlor) <www.angi.ru $>$ Aktau News (Aktau)

Azerbaijan 2012: The Business Year

Bloomberg Business News <http://www.bloomberg.com/>

Central Asia-Caucasus Analyst (Washington DC)

China Daily (Beijing)

Daily Telegraph (London)

Energo News (Moscow)

Energyland.info $<$ www.energyland.info $>$

Eurasia Daily Monitor

European Energy Policy Observer

Ferghana News $<$ http://www.fergananews.com $>$

Financial Times

gazeta.uz, <www.gazeta.uz $>$

Gulf Oil Review

ICIS Heren, European Gas Markets (London)

IHS Global Insight Daily analysis

Interfax-Azerbaijan

Interfax-Kazakhstan

Interfax Natural Gas Daily

International Water Power \& Dam Construction

Itar-Tass $<$ http://www.itar-tass.com/ $>$

Ivest.kz web site $<$ http://news.ivest.kz $>$

Kapital (Almaty)

Kazakhstan Today (Astana)

Kazenergy (Astana)

Kommersant (Moscow)

Kursiv (Almaty)

NefteCompass

Neftegazexpert web site <www.neftegazexpert.ru>

Neft' Gaz i mineral'nye resursy Turkmenistana

Neft' i kapital web site $<$ www.oilcapital.ru $>$

News.Az news agency $<$ http://www.news.az/>

Nezavisimaia Gazeta (Moscow)

Novosti Kazakhstan

Novosti Uzbekistana web site $<$ www.novostiuzbekistana.st.uz $>$

Nur.Kz news agency, Astana $<$ http://news.nur.kz $>$;

Oil \& Gas Journal (Houston)

Oil Capital $<$ www.oilcapital.ru $>$

Oxford Energy Forum

Platt's European Gas Daily

Platt's International Gas Report

Podrobno.uz news agency $<$ http://podrobno.uz/>

Pressa.tj news agency, Tajikistan $<w w w . p r e s s a . t j>$

RFE-RL $<$ http://www.rferl.org/>

Regnum.ru news agency $<$ http://www.regnum.ru/ $>$

Reuters $<$ http://www.reuters.com/ $>$

Rosbalt.ru $<\mathrm{http}: / /$ www.rosbalt.ru/ $>$

Rusenergy.com web site $<$ http://www.rusenergy.com $>$ 
SZ Energy web site $<$ http://www.szenergy.biz/>

Tengri News $<$ http://tengrinews.kz $>$

Today's Zaman (Ankara)

Tsentral'naia Evraziia (Tashkent)

Tsentraziia

Turkmenistan

Turkmenistan: zolotoi vek <www.turkmenistan.gov.tm>

Turkmenistan.ru $<$ http://www.turkmenistan.ru $>$

UPI news agency $<\mathrm{http}$ ://www.upi.com $>$

Upstream (London)

Uzbekistan Investment Guide <www.investor.uz>

Uzbekskii zhurnal neft i gaza (Tashkent)

Uzinform $<$ www.uzinform.com/ru/ $>$

Uzmetronom news agency $<\mathrm{http}: /$ www.uzmetronom.com/ $>$

Vedomosti (Moscow)

Vzglyad.ru <http://www.vzglyad.ru/>

World Gas Intelligence

Zonaks news agency, Kazakhstan <www.zonakz.net $>$

\section{Books and articles}

Adibi, Siamak and Fesharaki, Fereidun (2011), "The Iranian Gas Industry" in Jonathan Stern and Bassam Fattouh (eds.), Natural Gas Markets in the Middle East and North Africa (Oxford: Oxford University Press, 2011).

Babali, Tuncay (2009): "Prospects of export routes for Kashagan oil", Energy Policy 37 (2009), pp. 1298-1308.

Bairamova, I.A. et al. (eds.) (2011):, Nauchnye osnovy dal'neishego progressa gazovoi otrasli Turkmenistana: Sbornik statei (Ashgabat: Turkmenskaia gosizdat, 2011), vols. I and II.

Blackmon, Pamela (2011): In the Shadow of Russia: reform in Kazakhstan and Uzbekistan (East Lansing: Michigan State University Press, 2011).

Bowden, Julian (2009): “Azerbaijan: from gas importer to gas exporter", in Pirani (ed.)(2009), pp. 203-234.

Burak, Maksim and Saginova, Daria (2012): "Novyi zakon Respubliki Kazakhstan 'O gaze i gazosnabzhenii””, 23 January $2012<$ http://www.gratanet.com/ru/publications/457>

Chen, Michael Xiaobao (2012): “Gas Pricing in China”, in Stern (ed.)(2012), pp. 310-337.

Cutler, Robert (2012): Kazakhstan's “Resource Nationalism”: Its Sources and Motives (Elliott School of International Affairs, Central Asia Economic Paper no. 2, September 2012)

De Cordier, Bruno (2012): Can an Arab Uprising Scenario also Happen in Southern Eurasia? (Elliott School of International Affairs, Central Asia Research Paper no. 2, October 2012)

Geller, E.I. (2011): Structural and Geopolitical Developments of Central Asian Gas Market in the Period of Crisis (Moscow: ERI-RAS, 2011) 
Henderson, James (2010): Non-Gazprom Gas Producers in Russia (Oxford: Oxford University Press, 2010)

Henderson, James (2011): Domestic Gas Prices in Russia - Towards European Netback? (Oxford: OIES, November 2011)

Henderson, James, Pirani, Simon and Yafimava, Katja (2012): “CIS Gas Pricing: Towards European Netback?", in Jonathan Stern, The Pricing of Internationally Traded Gas (Oxford: Oxford University Press, 2012)

Ibragimov, R (2012): "Vliianie ekonomicheskikh faktorov na vozmozhnosti uregulirovaniia Nagorno-Karabakhskogo konflikta" in Tsentr Strategicheskikh Isledovanii, Azerbaidzhan: put' $k$ nezavisimosti (SAM: Baku, 2012)

Kalyuzhnova, Yelena (2008): Economics of the Caspian Oil and Gas Wealth (Basingstoke: Palgrave Macmillan, 2008)

Kalyuzhnova, Yelena and Kaser, Michael (2005): Prudential Management of Hydrocarbon Revenues in Resource-Rich Countries (Geneva, United Nations Economic Commission for Europe, 2005)

Kalyuzhnova, Yelena and Nygaard, Christian (2008): "State governance evolution in resource-rich transition economies: an application to Russia and Kazakhstan", Energy Policy 36 (2008), pp. 1829-1842

Kinnander, Elin (2010): The Turkish-Iranian Gas Relationship: Politically Successful, Commercially Problematic (Oxford, OIES, January 2010)

Kjaernet, Heidi (2009): “The Energy Dimension of Azerbaijani-Russian Relations: maneuvering for Nagorno-Karabakh”, Russian Analytical Digest 56 (2009), pp. 2-5

LeVine, Steve (2007): The Oil and the Glory: the pursuit of empire and fortune on the Caspian Sea (Random House: New York, 2007)

Luecke, Matthias and Trofimenko, Natalia (2008): "Whither Oil Money? Redistribution of oil revenues in Azerbaijan", in Najman, Pomfret and Raballand (eds.), The Economics and Politics

Luong, Pauline Jones and Weinthal, Erika (2010): Oil is Not a Curse: ownership structure and institutions in Soviet successor states (New York: Cambridge University Press, 2010)

Najman, Boris Pomfret, Richard Raballand, Gael and Sourdin, Patricia (2008):

"Redistribution of oil revenue in Kazakhstan", in Najman, Pomfret and Raballand (eds.) (2008)

Najman, Pomfret and Raballand (eds) (2008): The Economics and Politics of Oil in the Caspian Basin. The redistribution of oil revenues in Azerbaijan and Central Asia (London: Routledge, 2008) 
Nixey, James (2012): The Long Goodbye: Waning Russian Influence in the South Caucasus and Central Asia (Chatham House Briefing Paper, June 2012)

Ostrowski, Wojciech (2010): Politics and Oil in Kazakhstan (London: Routledge, 2010

Paramonov, Vladimir (2008): The future supply of gas from Central Asia to Russia (Shrivenham, Defence Academy of the UK, 2008)

Peyrouse, Sebastien (2012): Turkmenistan: strategies of power, dilemmas of development (London, M.E.Sharpe, 2012)

Pirani, Simon (ed.) (2009): Russian and CIS Gas Markets and their Impact on Europe (Oxford: Oxford University Press, 2009)

Pirani, Simon (2011): Elusive Potential: Gas Consumption in the CIS (Oxford: OIES, 2011)

Pirani, Stern and Yafimava (2010): The 2010 Russo-Ukrainian gas agreement and its implications for Europe (OIES Working Paper 2010)

Pomfret, Richard (2006): The Central Asian Economies Since Independence (Oxford: Princeton University Press, 2006)

Rzayeva, Gulmira and Tsakiris, Theodoros (2012): Strategic Imperative: Azerbaijani Gas Strategy and the EU's Southern Corridor (Baku, SAM Center for Strategic Studies, 2012)

Sabonis-Helf, Theresa (2004): "The Rise of the Post-Soviet Petro-States: Energy Exports and Domestic Governance in Turkmenistan and Kazakhstan", in In the Tracks of Tamerlane: Central Asia's Path to the 21st Century (Washington: National Defense University, 2004), pp. $159-185$

Sarsenbayev, Kuanysh (2011): "Kazakhstan petroleum industry 2008-2010: trends of resource nationalism policy?", Journal of World Energy Law \& Business vol. 4 (2011) no. 4, pp. $369-379$

Sorbello, Paolo (2011): The Role of Energy in Russian Foreign Policy Towards Kazakhstan (Saarbrucken: Lambert Academic Publishing, 2011)

Stern, Jonathan (2005): The Future of Russian Gas and Gazprom (Oxford: Oxford University Press, 2005)

Stern, Jonathan (2009): “The Russian Gas Balance to 2015”, in Pirani (ed.)(2009)

Stern, Jonathan (ed.) (2012): The Pricing of Internationally Traded Gas (Oxford: Oxford University Press, 2012)

Stern, Jonathan and Fattouh, Bassam (2011): Jonathan Stern and Bassam Fattouh (eds.), Natural Gas Markets in the Middle East and North Africa (Oxford: Oxford University Press, 2011)

Stern, Jonathan and Rogers, Howard (2012): "The Transition to Hub-Based Gas Pricing in Continental Europe", in Stern (ed.), The Pricing of Internationally Traded Gas, pp. 145-177. 
Tashliev, M.Sh.(2020): Melovye otlozheniia Turkmenistana: regional'naia litmologiia $i$ neftegazonosnost' (Ashgabat: Turkmenskaia gosizdat, 2010)

Tokmazishvili, Micheil and Bowden, Julian (2009):“Georgia’s Gas Sector”, in Pirani (ed.) (2009)

Valdez, Marla and Weaver, Kenyon (2012): “Turkmenistan”, in ICLG to Gas Regulation 2012, p. 285

Yenikeyeff, Shamil (2009): “Kazakhstan's Gas Sector”, pp. 325-326, in Pirani (ed.) (2009)

Zhukov, Stanislav (2009): “Uzbekistan: a domestically oriented gas producer", in Pirani (ed) (2009)

Zhukov, Stanislav and Reznikova, Olga (2009): Tsentral'naia Aziia i Kitai:

ekonomicheskoe vzaimodeistvie v usloviakh globalizatsii (Moscow: IMEMO RAN, 2009) 